\title{
LIGGAAMLIKE OPLEIDING IN DIE UNIE-VERDEDIGINGSMAG (1912-1946)
}

\section{AGTERGROND EN PROBLEEMSTELLING}

\subsection{Inleiding}

Om weerbaar te wees veronderstel die bestaan van 'n bedreiging en die vermoë om daardie bedreiging die hoof te kan bied. Om, militêr gesproke en in georganiseerde verband weerbaar te wees, vereis nie alleen om oor 'n deeglik toegeruste weermag te beskik nie, maar terselfdertyd dat elke lid homself op enige tydstip ten volle kan en wil gee aan die uitvoering van 'n hoogs verantwoordelike taak wat van hom, in diens en as lid van 'n bepaalde groep of nasie verwag word.

Die suksesvolle uitvoering hiervan het dwarsdeur die geskiedenis sowel van die menslike oorwegings, as van die bewapening en die fisieke vermoëns van die mens afgehang.

Ofskoon die metodes van oorlogvoering in die loop van die eeue alhoemeer 'n sterk tegniese inslag gekry het, bly die rol van die weerbare mens nog altyd belangrik.

\subsection{Probleemstelling}

In die verlede is daar, deur vakkundiges in ons land, weinig aandag aan die bestudering van liggaamlike opvoeding as 'n waardevolle aspek van die militêre weerbaarheid van die krygsman, hetsy vrywilliger of dienspligtige, gewy.

'n Uitsondering hierop is T. J. Loubser wat in sy verhandeling: Die plek van Liggaamlike Opvoeding in militêre opleiding in die Suid-Afrikaanse leër, Potchefstroom, 1961, 'n beknopte agtergrondskets van die vak in die Suid-Afrikaanse leër tot en met die Tweede Wêreldoorlog gegee het.

In genoemde ondersoek het die skrywer 'n besonder duidelike uiteensetting van dié vak na die Tweede Wêreldoorlog gegee.

Dit lei tot die gevolgtrekking dat liggaamlike opleiding*, wat so 'n uiters belangrike rol in die militêre opleiding speel, dieper nagevors behoort te word.

Hierdie navorsing sluit noodwendig die geskiedenis van die vak in die vorm van metodes, resultate, vergelykende materiaal en verskillende wyses van beïnvloeding in.

In die lig hiervan kan, op grond van 'n sintese dan 'n stewige gefundeerde: doeltreffende en bygevolg bruikbare stelsel opgebou word wat aan ons hedendaagse vereistes voldoen en - met die oog op die toekoms - voldoende buigbaar is om by veranderde omstandighede en vereistes aan te pas.

In die lig van verskeie aanklagte wat van tyd tot tyd teen die fisieke fiksheidspeil van die Suid-Afrikaanse jeug in nuus- en ander media gelê word, is dic begrippe liggaamlike opleiding, liggaamlike opvoeding en fisieke fiksheid omskryf, terwyl die noodsaaklikheid van so 'n opleiding weereens onder die aandag van almal gebring word wat daarmee gemoeid is.

* Die term liggaamlike opleiding is en word tot vandag toe veral by die gewapende magte aangetref waar dit gebruik word om die hele program van liggaamlike kondisionering aan te dui. Om dié rede sal dit in hierdie verhandeling gebruik word waar dit op die militêre aspek betrekking het. 
Liggaamlike opleiding in die Unie-Verdedigingsmag het na die Eerste Wêreldoorlog in 'n baie groot mate sy ontwikkeling te danke aan die aanvoorwerk wat deur Britse deskundiges hier te lande gedoen is. Dit moet gesien word teen die agtergrond van die Britse verdedigingsorganisasie en sy toenmalige doelstellings op hierdie vakgebied.

As verdere agtergrond tot hierdie studie dien laastens 'n skets van die ontstaan en ontwikkeling van die Unie-Verdedigingsmag van 1912 tot 1946.

Teen hierdie agtergrond is dan agtereenvolgens 'n poging aangewend om :

1 Die begrippe liggaamlike opleiding, liggaamlike opvoeding en fisieke fiksheid te definieer.

2 Die noodsaaklikheid van laasgenoemde faktor te beklemtoon.

3 Die ontstaan en ontwikkelingsgang van liggaamlike opleiding in die Unie-Verdedigingsmag vanaf 1912 tot 1946 te skets. 


\section{OMSKRYWING VAN BEGRIPPE}

\subsection{Inleiding}

Geskiedenis kan omskrywe word as 'n rekord wat veranderinge van een tydperk na 'n ander aandui. Die oorgang van een tydperk na 'n ander vind egter so geleidelik plaas dat dit uiters moeilik is om presies te bepaal wanneer die een tydperk begin en wanneer dit eindig. Soms vind daar soveel veranderinge binne die bestek van 'n kort tydjie plaas dat 'n spesiale tydvak geskep word.

Presies dieselfde het gebeur met die terme liggaamskultuur, liggaamlike opleiding en liggaamlike opvoeding. Daar was nie presiese afgebakende tye wat aandui wanneer die een begin en die ander opgehou het nie. Selfs in 1938, met die stigting van die Nasionale Adviserende Raad vir Liggaamlike Opvoeding, is daar nog in amptelike Afrikaanse geskrifte na liggaamskultuur verwys.

In Oos-Duitsland word die woorde,, Körper” en „Kultur” in teenstelling met die Wes-Duitse woord „Leibserziehung” gebruik. Hierdie drie terme is nie sinoniem nie, maar stel 'n ontwikkeling, 'n verandering van begripsinhoud en interpretasie voor.

\subsection{Liggaamskultuur}

Die term liggaamskultuur het teen die middel van die 19de eeu, gedurende die sogenaamde ,kultuurperiode," populêr geword. Dit was oorspronklik die gelyke term wat gebruik is om na sekere vakke soos musiek, naaldwerk, e.d.m. as kultuurvakke te verwys.

Smit $(65: 5)$ stel dit duidelik dat liggaamskultuur die opvoeding van die fisieke is en dat sy aanhangers die opbou van sterk spiere en stewige liggame as die vernaamste doelwit beoog.

In Amerika was hierdie term ongeveer tussen 1820 en 1880 in swang en hoewel dit uiteindelik deur die term liggaamlike opleiding vervang is, is dit tot laat in die 20ste eeu nog deur kwaksalwers gebruik om hul kursusse in skoonheid, gesondheid en kragontwikkeling aan die man te bring.

\subsection{Liggaamlike Opleiding}

Die term liggaamlike opleiding het gedurende die periode, toe die liggaamlike opvoedingsaktiwiteite deur sierlikheidsgimnastiek en gewone gimnastiek gekenmerk was, sy verskyning gemaak. Dit het veral onder die invloed van die sogenaamde gimnastieksisteme tot stand gekom.

Smit $(65: 5)$ wys daarop dat die vernaamste invloede uit Duitsland, Swede en Engeland afkomstig was. Die Engelse het hoofsaaklik hul bydrae op die gebied van sport en spele gelewer.

Dit was veral die vroeëre Duitse en Sweedse gimnastiekstelsels wat die ,oefening” of ,opleidingsidee" bevorder het.

Die Duitse gimnastieksisteem het sy oorsprong by Turnvater Friedrich Ludwig Jahn (1778-1852) gehad. In sy tyd het die grootste deel van die toenmalige Duitse Ryk onder beheer van Napoleon gekom en dit was Jahn se strewe om 'n vrye en verenigde Duitsland te laat herrys. Liggaamlike opvoeding het vir hom 'n saak van nasionale belang beteken wat bedoel was om die jong Duitsers fiks te maak om met welslae hul nasionale vryheid te kan herwen $(3: 261)$. 
Ook die Sweed Per Henrik Ling (1776-1839) het, aangevuur deur dieselfde ideale as Jahn, die bevordering van nasionale eenheid in die lig van die beoefening van gimnastiek gesien. Hy het dit as 'n middel tot verbetering van die doeltreftendheid van die Sweedse leër in die vorm van formele liggaamsdril beskou (25: 207).

Militêre behoeftes het, nou in Swede, weereens daartoe bygedra om 'n sisteem vir liggaamlike opvoeding daar te stel. Die Sweedse stelsel is deur die leërs van verskeie lande toegepas. Dit het in die nasionalisme van daardie tyd en die opvatting met betrekking tot dissipline ingepas, maar het nie 'n deel van die algemene opvoeding gevorm nie.

In die eerste helfte van die 19de eeu het die invloed van hierdie liggaamsoefening-sisteem o.m. na Engeland en Amerika versprei. Hierdie invloede is o.m. ook sigbaar in die Code of Regulations for Elementary Schools wat in 1871 in Engeland gepubliseer is. In hierdie regulasies word na liggaamlike opvoeding verwys as drill wat deur leërdrilinstrukteurs wat aan die Leërgimnasium te Aldershot opgelei is, aangebied is. Die woord drill is in die hersiene Britse regulasies van 1890 deur die uitdrukking liggaamsoefeninge vervang $(64: 6)$.

Dic term liggaamlike opleiding is en word tot vandag toe veral by die gewapende magte aangetref waar dit gebruik word om die hele program van liggaamlike kondisionering aan te dui wat aangewend word ter voorbereiding vir die soldaat se veeleisende en gespesialiseerde taak. In hierdie term beteken opleiding die liggaamlike bekwaammaking vir 'n spesifieke doel.

MacKenzie $(51: 141)$ sien opleiding as 'n term toepasbaar oor die ver kryging van vaardighede en in wese handel liggaamlike opleiding oor die verkryging van spiervaardighede.

Vir Webster $(23: 114)$ het liggaamlike opleiding die betekenis van gesag, formaliteit en gehoorsaamheid met die klem op verkryging van vaardigheid, liggaamlike fiksheid en die kondisionering van die liggaam vir die ontwikkeling van krag en uithouvermoë.

In so 'n opleidingstelsel is daar min geleentheid vir die ontwikkeling van inisiatief, selfuiting, genot of aanvaarbare sosiale waardes. Dit dien slegs een definitiewe doel: Die voorbereiding vir militêre diens.

Net soos onderwys 'n aspek van opvoeding is, net so is liggaamlike opleiding 'n aspek van liggaamlike opvoeding. Liggaamlike opleiding het te make met fisieke fiksheid en is en bly steeds 'n onmiddellike doelstelling van liggaamlike opvoeding.

Die begrip liggaamlike opvoeding is 'n poging om 'n term te vind wat die breë opvatting (net soos rekreasie en ontspanning) weerspieël en is veral kenmerkend van die nuwe sielkundige en opvoedkundig-wyserige denkrigtings van ons eeu.

Die verskil tussen liggaamlike opleiding en liggaamlike opvoeding lê veral daarin opgesluit dat die sosiale aspek in die term liggaamlike opvoeding beklemtoon word en andersins nie.

\subsection{Liggaamlike Opvoeding}

Die begrip liggaamlike opvoeding word deur verskillende liggaamlike opvoedkundiges op uiteenlopende maniere omskryf. 
Nash (11:47) sien liggaamlike opvoeding as 'n fase van totale opvoeding wat tot dic verwesenliking van al die doelstellings van opvoeding bydra. Opvoeding en liggaamlike opvoeding bevat, volgens hom, dus gemeenskaplike doelstellings wat om die opvatting van kragtige organiese gesondheid, nastrewing van vaardigheid in werk en vryetydsbesteding, die vermoë om helder te dink en die besit van emosionele dryfvere gesentreer is, wat die welsyn van alle mense in 'n globale omvang insluit.

Die liggaamlike opvoeder maak, volgens dieselfde skrywer, van aktiwiteite wat inherent is en elke individu gebruik om 'n persoon organies, neuro-muskulêr, intellektueel en emosioneel te ontwikkel.

Nixon (12:6) e.a. defineer liggaamlike opvoeding as daardie fase van die hele proses van opvoeding wat betrekking het op die kragtige spierbewegings en verwante response en met die modifikasies van die individu wat uit hierdie response volg. Benewens ander uitwerkings bevorder rasionele spieroefeninge die groei en ontwikkeling, versterk en vergroot dit die spiere, verbeter die spiertonus en vermeerder die krag van die organiese sisteem van die liggaam.

Bogenoemde skrywer verklaar ook dat dit ondenkbaar is om 'n stelsel van liggaamlike opvoeding te ontwerp en aan te bied sonder dat die individu in situasies betrek word waaruit geestelike en emosionele reaksies te voorskyn tree wat ' $n$ verandering in gewoontes, gedrag, waarderings of vaardighede tot gevolg het $(12: 6)$.

Sharman (16:59) wys daarop dat die periodes waarin kinders speel deur bevoegde onderwysers aangewend kan word om die kinders te lei om gewenste gedragwyses teenoor spanmaats, teenstanders, toeskouers en sportbeamptes aan te kweek.

Op sy beurt beskou MacKenzie (51 : 141) liggaamlike opvoeding as 'n deel van die opvoedingsproses wat bydra tot die ontwikkeling van elke individu deur die groot spieraktiwiteite en deur die response wat uit sulke aktiwiteite voortspruit. Hierdie response is emosioneel, en sedelik sowel as intellektueel en liggaamlik.

Dit word vandag aanvaar dat die mens 'n liggaamlik-geestelike totaliteit is. Die opvoeding het altyd met die totaliteit en nooit met afsonderlike wesensaspekte van die mens te doen nie.

In die lig van die uniek-geïntegreerde eenheid van die mens, beskryf Van der Merwe $(67: 11)$ liggaamlike opvoeding ,as die opvoeding van die totale mens as geintegreerde eenheid met die fisiese as uitgangs- en aanknopingspunt."

Vir die doeleindes van begripsbepaling kan ons volstaan met die definisie van Smit (85) waarin hy liggaamlike opvoeding beskou as 'n integrerende deel van die totale opvoedkunde wat byna uitsluitlik geskied d.m.v. spesiaal uitgesoekte psigo-motoriese grootspier-aktiwiteite en verwante ervarings, ter ontwikkeling van veral liggaamlik, maar ook geestelik, emosionecl en sosiaal geskikte burgers.

\subsection{Fisieke Fiksheid}

Die mens was sedert die begin van die klassieke Westerse en Oosterse beskawings gemoeid met die liggaamlike ontwikkeling van homself en sy soortgenote. Vandag is dit nog steeds die geval.

Die huidige doelstellings bly dieselfde as dié wat deur die eeue geformuleer is, nl. om die eise, deur omgewings- en erflikheidstoestande bepaal, so goed a i moontlik te bevredig. Elke verandering in die beskawing in die loop van die eeuc het ook 'n verandering in die doelstellings ten opsigte van die noodsaaklikheid vir liggaamlike fiksheid meegebring. 
'n Oorsig oor die literatuur wat handel oor liggaamlike fiksheid voor die Tweede Wêreldoorlog toon aan dat die groot verskeidenheid definisies verwarring veroorsaak het by diegene wat in hierdie vakgebied en in sy probleme geinteresseerd was. Andersyds dui dit o.i. op die strewe om aan te pas by die behoeftes van die tyd en om deur uiteenlopende benaderings die eintlike wese van liggaamlike fiksheid te probeer deurgrond.

Sommige definisies is en word aangebied in terme van kapasiteit vir werk waarvolgens individue, wat oor groot werksvermoë beskik, as die fiksste geklassifiseer is. Ander is geformuleer in terme van liggaamlike gebreke met die veronderstelling dat daar 'n funksionele verwantskap tussen liggaamlike gebreke en liggaamlike fiksheid bestaan. Sommige navorsers weer, het liggaamlike fiksheid volgens sekere komponente gedefinieer wat spierkrag, tesame met kardiorespiratoriese funksies, as die basis vir fisieke fiksheid ingesluit het $(5: 156)$.

Gedurende die Tweede Wêreldoorlog is die begrip liggaamlike fiksheid bestendig. Militêre instansies het dit omskryf as die vermoë om lang en strawwe spierinspanning vol te hou $(5: 156)$.

Liggaamlike fiksheid is een van die doelstellings van liggaamlike opvoeding en dit is ook die enigste doelstelling wat uitsluitlik deur stelselmatige toepassing van 'n behoorlik gebalanseerde program van liggaamlike opvoeding bereik kan word.

Liggaamlike fiksheid is uniek - dit kan nie deur die beste mediese behandeling nie, maar slegs deur strawwe reëlmatige oefening verkry word.

Ten einde die wese van liggaamlike fiksheid te probeer deurgrond, is dit noodsaaklik dat enkele omskrywings van dié begrip ontleed word.

Brouha $(33: 24)$ is van mening dat liggaamlike fiksheid die vermoë is om inspannende werk op 'n doeltreffende wyse uit te voer.

Larson (49:18) omskryf liggaamlike fiksheid weer as die wese en graad van aanpassing in aktiwiteite wat spierarbeid vereis. In hierdie verband dui wese daarop of die aanpassing met gemak (sonder psigiese of fisiologiese spanning) of met aansienlike poging (met psigiese en fisiologiese spanning) geskied. Graad dui daarop dat aanpassings deurlopend en nie tweeledig is nie. Aanpassing dui op die verwantskap wat tussen die individuele status en die doelstelling van die aktiwiteit bestaan. Volgens laasgenoemde navorser is daar twee bepalende faktore van fiksheid wat na vore tree in die omskrywing van fiksheid, nl.:

a Die doel met liggaamlike fiksheid en

b die aard van die liggaamsbou en funksie wat nodig is om die korrekte aanpassing te bewerkstellig met die oog op die doel wat nagestrewe word.

Wat die definisie van Larson belangrik maak, is die feit dat die verband wat daar tussen liggaamlike en geestelike fiksheid bestaan na vore tree.

Vir Steinhaus $(66: 427)$ beteken fiksheid oorlewing en dit vereis :

1 Die afwesigheid van siekte en belemmerende gebreke.

2 Voldoende spoed, krag, vaardigheid en uithouvermoë om die daaglikse take maklik en die maksimum take wat die dag mag oplewer, met welslae uit te voer.

3 Bekwaamheid en gewilligheid om nuttige werk te verrig. 
4 Die afwesigheid van bekommernis en buitensporige spanning en die vermoë om vinnig van volkome konsentrasie na totale ontspanning soos die behoeftes en geleenthede wat diz oomblik vereis, oor te slaan.

5 'n Persoonlike filosofie wat die wêreld, soos dit waargeneem word, bevredigend verklaar of na waarde skat.

6 'n Gevoel om saam met ander 'n deel van belangrike take uit te voer en dadelik belangrik in dié verband te wees.

Bostaande definisie omskryf totale fiksheid in breë trekke. Liggaamlike fiksheid is slegs een aspek van totale fiksheid wat ander aspekte soos emosionele, geestelike en sosiale fiksheid insluit.

In 1958 het die Kanadese Sports Advisory Council (81:7), in samewerking met die Spelevereniging van die Britse Ryk on die Gemenebes, 'n fisieke bevoegdheidsnavorsingsprojek van stapel gestuur. Volgens bogenoemde instansies bestaan totale fiksheid uit die volgende elemente :
a emosionele stabiliteit;
b geestelike sekuriteit;
c sosiale geskiktheid;
d fisieke fiksheid.

Hierdie totale fiksheid verskil opmerklik van individu tot individu en van tyd tot tyd en ook in een en dieselfde mens. Die graad waartoe elkeen van hierdie kapasiteite, beide afsonderlik of gesamentlik, ontwikkel het, bepaal die graad van totale fiksheid waaroor die individu op daardie tydstip beskik.

'n Deeglike beplande program vir liggaamlike opvoeding kan 'n baie waardevolle bydrae tot die verkryging van totale fiksheid lewer. Soos reeds daarop gewys is, is fisieke fiksheid een doelstelling van liggaamlike opvoeding wat byna uitsluitend deur die deelname aan liggaamlike opvoeding verwesenlik word. Hoewel fisieke fiksheid een aspek van totale fiksheid uitmaak, is dit egter in die reël die basis waarop emosionele stabiliteit, geestelike sekuriteit en sosiale gesondheid rus.

In hierdie verband onderskei Schrecker $(61: 40)$ tussen fiksheid wat, algemeen gesproke, beteken om geskik te wees om iets te doen. By hom beteken liggaamlike fiksheid dus die vermoë om iets fisies te doen. Wat ook al liggaamlik gedoen word, is in terme van fisika, werk.

Dit is volgens hom in alle liggaamlike aktiwiteite, ook dié deur die mens uitgevoer, waar 'n massa oor 'n gegewe distansie met 'n sekere versnelling beweeg word, aanwesig. Gevolglik beteken fisieke fiksheid, in die algemeen gesproke, die vermoë om werk in hierdie sin te verrig $(61: 40)$.

Dieselfde skrywer wys verder daarop dat dit natuurlik nie impliseer dat 'n persoon, ten einde liggaamlik fiks te wees, werklik in staat moet wees om alle soorte arbeid in die sin van die alledaagse lewe te verrig nie; dit is alle soorte doelgerigte aktiwiteite wat uit die een of ander nuttige doelstelling voortspruit $(61: 40)$.

Die verdeling van arbeid het tot so 'n ingewikkelde spesialisasie van werk gelei, dat die verkryging van so 'n universele liggaamlike fiksheid vir 'n enkele persoon volslae onmoontlik is.

Dus, om nie heeltemal idealisties te raak nie, is dit nodig dat liggaamlike 
spring en gooi, trek en stoot, optel en dra, klim, balanseer, swaai en vang wat die verskillende soorte van hande-arbeid ten grondslag lê, moet bemeester word $(61: 40)$.

Om liggaamlik fiks te wees impliseer aldus Schrecker, meer as die vermoë om hande-arbeid te verrig. Dit is ook in ander liggaamlike aktiwiteite dat werk, in terme van die fisika, gedoen word. Dit word, om slegs een voorbeeld te noem, in noodgevalle soos selfverdediging gedoen. Dit word verder betrek in sekere liggaamsaktiwiteite soos goëltoertjies, dans en speel wat die mens as 'n nie suiwer rasionele wese ter wille van homself of ter wille van die uitdrukking van innerlike gevoelens uitvoer. Laasgenoemde vorme van liggaamlike aktiwiteite dien ingelyks essensiële behoeftes en bovermelde fondamentele bewegings vorm ook die basis hiervan.

Met die voorafgaande in gedagte beteken liggaamlike fiksheid vir Schrecker om aangepas te wees om fisieke werk in die vorm van basiese bewegings te verrig ongeag die liggaamlike aktiwiteit wat daarby betrokke is $(61: 40)$. Vergelyk hiermee die definisie van Du Toit $(87: 1)$ waarin hy liggaamlike fiksheid verklaar as om in staat te wees om werk in die vorm van basiese bewegings soos opgesluit in enige liggaamlike aktiwiteit en aspekte soos $\mathrm{krag}$, spoed, uithouvermoë (as energie) en behendigheid (as doeltreffendheid) behels, te verrig.

Die peil van fiksheid wat ontwikkel kan word, sal afhang van die oorgeëfde liggaamstipe, die gesondheidstatus en die mate waartoe die persoon se fisieke bevoegheidspotensiaal ontwikkel is.

\section{a Oorerwing}

Die beenstruktuur wat 'n persoon erf, bepaal die hoogte, die breedte en die lengte van sy liggaam en kan basies nie veel verander nie. Oorerwing bepaal ook die aantal en patroon van die indiwiduele spierweefsels waaruit die verskillende spiere van die menslike liggaam saamgestel is. Hierbenewens bepaal oorerwing ook die neigings en die potensiële perke van die indiwiduele menslike organe b.v. suurstofopname. Gevolglik is die potensiaal as 'n geheel vooraf bepaal. Die belangrikheid lê egter nie daarin wat ons erf nie, maar hoe ons dit versorg en tot watter mate ons ontwikkel (81:7-8).

b Gesondheidstatus

Fiksheid berus in die eerste plek op 'n stewige grondslag van goeie gesondheid $(26: 11)$. Die menslike liggaam het gereelde en intellektuele versorging nodig. Daaglikse gesondheidsgewoontes soos voldoende en gereelde slaap, 'n bepaalde hoeveelheid rus, 'n gebalanseerde en bevredigende dieet, strawwe en inspannende liggaamsoefeninge e.d.m. is noodsaaklik. Gereelde mediese en tandheelkundige ondersoeke en dienste verskaf die nodige basis om die optimale gesondheid in ooreenstemming met die oorgeërfde potensiaal, inherente en verworwe gebreke te geniet.

Aangesien die mediese wetenskap byna alle aansteeklike siektes elimineer en middels verskaf of gebreke geheel en gedeeltelik uit te skakel, is dit moeilik om te voorspel tot watter mate fisieke fiksheid toegeneem het. Die klem het egter van die vryheid van siektes na die ontwikkeling van die optimum positiewe gesond- 
Vir 'n groot aantal navorsers op die gebied van fisieke fiksheid was hierdie beskouing in die verlede nie altyd aanvaarbaar nie. Sommige het fisieke fiksheid omskryf as die vermoë om die normale aktiwiteite van die lewe sonder enige buitengewone emosionele en liggaamlike vermoeidheid uit te voer. 'n Groot aantal, soos Wilson (71: 391), die Baruch sub-komitee (1:167), Morehouse en Miller $(9: 310)$ en McPartlin $(8: 10)$, het beweer dat fisieke fiksheid spesifiek is, d.w.s. 'n persoon mag fiks wees om vir 'n uur sokker te speel, maar nie in staat wees om 1500 meter te swem nie.

Ons moet dus onderskei tussen algemene of basiese en gespesialiseerde of spesifieke fisieke fiksheid. Albei hierdie soorte fiksheid is meetbaar.

\subsubsection{Basiese Fisieke Fiksheid}

Basiese fisieke fiksheid is 'n gebalanseerde ontwikkeling van die spieren organiese krag in verhouding tot die fisieke en moet meer as voldoende wees om aan die daaglikse eise van die normale lewe te voldoen $(81: 9)$.

Vir Smit (85) is die bereiking van die basiese fisieke fikshed binne die bereik van elke normale mens. Elkeen behoort, ongeag sy beroep, oor basiese fisieke fiksheid te beskik om 'n volwaardige lewe as 'n nuttige burger van sy gemeenskap te kan lei, want elkeen moet daagliks sekere fondamentele aktiwiteite uitvoer om die lewe te kan handhaaf. Die spiere, hart en longe moet oor genoegsame reserwekragte beskik om hierdie aktiwiteite doeltreffend te kan uitvoer. Dit moet beklemtoon word dat die daaglikse normale program van enige persoon die stap van 'n paar myl, die staan van enige ure, sit en ander aktiwiteite weer spierwerking tot gevolg het. Smit (85) stel dit duidelik dat wanneer, afgesien van wat hulle doen, spiere werk, hulle energie verbruik. Hierdie energie word, volgens dieselfde outeur, verkry van voedsel en lug wat deur die hart en longe na die spiere vervoer word. Dus, hoe doeltreffender die spier werk, des te minder energie het dit nodig om 'n gegewe hoeveelheid arbeid te verrig. Hy vervolg: Hoe doeltreffender die hart en longe hul werk verrig, des te minder energie hierdie organe nodig het om die voedingstowwe na die spiere te vervoer.

In die lig hiervan kan basiese fisieke fiksheid in ooreenstemming met Smit $(63: 20)$ se opvattings omskryf word as daardie toestand van die spiere, hart en longe wat dit vir die individu moontlik maak om sonder oormatige vermoeidheid of uitputting geïntegreerde en volgehoue prestasies te lewer waarvoor krag, uithouvermoë, spoed, soepelheid en algemene motoriese vermoë nodig is.

\subsubsection{Komponente van Basiese Fisieke Fiksheid}

Energie sowel as doeltreffendheid is grondvoorwaardes vir liggaamlike of fisieke fiksheid. Energie is die vermoë om werk te verrig. Werk, in terme van die fisika, is die produk van krag en afstand. Krag bestaan weer uit twee bestanddele, n.l. versnelling en massa. Ons kan dus sê dat energie $=$ versnelling + massa + afstand. Al drie hierdie faktore speel 'n rol in die situasie waarmee ons liggame te doen het $(63: 20)$. Wanneer die lewende organisme werk verrig, sal daardie gedeelte van die energie, was as meganiese energie werk verrig, as gevolg hiervan in drie vorms, spoed, krag en uithouvermoë $(61: 40)$ met inagneming van die sterkteverhoudings ten opsigte van bogenoemde drie faktore, verskyn.

Spoed is die vermoë om werk te verrig waarby 'n betreklik klein massa met groot versnelling oor ' $n$ kort afstand beweeg word. Die 100 tree naelloop is 'n voorbeeld van 'n spoedaktiwiteit. 
Krag is die vermoë om 'n werk te verrig waarby 'n betreklik groot massa met min versnelling oor 'n kort afstand beweeg word. Dit handstand op die brug kan hier as 'n voorbeeld genoem word.

Uithouvermoë is die vermoë om werk te verrig waarby 'n betreklik klein massa met min versnelling oor 'n lang afstand beweeg word $(61: 40)$. Tipiese uithouvermoë-aktiwiteite sluit o.a. hindernisresies, ski en roei in.

Behendigheid is die vermoë om die aanwending van energie in sy verskillende vorms ooreenkomstig die situasie te reguleer (63:20). Enige liggaamlike beweging, selfs die eenvoudigste soos wanneer die een arm sywaarts opgelig word met 'n sekere hoeveelheid krag in 'n sekere rigting oor 'n sekere afstand, moet só uitgevoer word dat die statiese en dinamiese ewewig van die liggaam bewaar word.

Bewceglikheid of soepelheid is die omvang waarin bewegings van die gewrigte uitgevoer word $(63: 20)$. Soepelheid berus op die elastisiteit van die bind- en spierweefsel rondom die betrokke gewrigte. As die gewrigte styf of die tonus van spiere te hoog is, sal 'n groot deel van die beskikbare energie vermors word om inwendige weerstand te oorkom. Hierdeur sal doeltreffendheid verminder word.

\subsubsection{Gespesialiseerde Fisieke Fiksheid}

Die Canadian Sports Advisory Council $(81: 12)$ is van mening dat gespesialiseerde fisieke fiksheid aangeleerde vaardighede van alle soorte soos dit in sport, werk en rekreasie gebruik word, insluit. Dit kan slegs tot dié mate behaal en ontwikkel word waarin individue oor basiese fisieke fiksheid beskik. As die spiere sterk genoeg is en die hart en longe doeltreffend genoeg funksioneer om die behendighede aan te leer en sonder oormatige vermoeidheid of inspanning te beoefen, is dit noodsaaklik dat 'n bevredigende peil van basiese fisieke fiksheid bereik word voordat die gespesialiseerde aktiwiteite beoefen word.

Alle behendighede het in 'n mindere of meerdere mate spier- en organiese krag nodig. Hierdie organiese krag word op verskillende maniere geïntegreer en gekoördineer afhangende van die persoon se liggaamsbou en die besondere aard van die behendigheid en vereis grotere of kleinere grade van ontwikkeling. Daarom is, aldus dic Canadian Sports Advisory Council, die ontwikkeling van behendighede spesifiek vir elke persoon sowel as vir elke behendigheid.

Basiese fisieke fiksheid verskaf die algemene spier- en organiese kragte as die grondslag waaruit verskeie hoogs gespesialiseerde gekoördineerde bewegings, bekend as behendighede, ontwikkel word.

In die lig van die voorafgaande dien daarop gewys te word dat 'n verdedigingsorganisasie daar gestel is om alles wat 'n volk se eie is te beskerm en te verdedig. Die beskermers moet fiks wees om hierdie taak te kan uitvoer. Enige militêre organisasie wat hiermee gemoeid is, moet sorg dat sy lede oor 'n baie hoë basiese fisieke fiksheidpeil beskik. Daarna kan gespesialiseerde fisieke fiksheid beoefen word om die lede in staat te stel om die hoogs gespesialiseerde take, wat eie aan die moderne verdedigingsorganisasies is, doeltreffend uit te voer.

Die beoefening van sport en spele speel 'n belangrike rol in die oplei- 
aliseerde fisieke fiksheid moet as basiese fisieke fiksheid opgebou word, terwyl tewens onthou moet word dat in gespesialiseerde behendighede gewoonlik een of meer komponente van basiese fisieke fiksheid oorbeklemtoon word. Die marathonhardloper sal b.v. uithouvermoë ten koste van spoed ontwikkel, terwyl die gewigopteller geneig sal wees om uithouvermoë te verwaarloos.

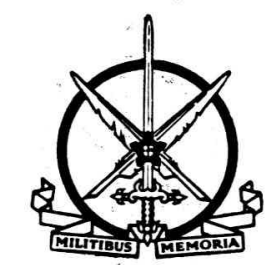

\section{Samevatting}

Ons onderskei tussen basiese en gespesialiseerde fisieke fiksheid. Basiese fisieke fiksheid is noodsaaklik om geïntegreerde en volgehoue prestasies sonder uitermatige vermoeidheid of uitputting te lewer. Die bestanddele waaruit basiese fisieke fiksheid saamgestel is, sluit spoed, krag, uithouvermoë, behendigheid en soepelheid in.

Basiese fisieke fiksheid vorm die basis waarop gespesialiseerde fisieke fiksheid opgebou en ontwikkel word.

'n Verdedigingsorganisasie mik na 'n baie hö̈ peil van basiese fisieke fiksheid en wanneer dit eers bereik is, moet daar aandag aan gespesialiseerde fisieke fiksheid geskenk word.
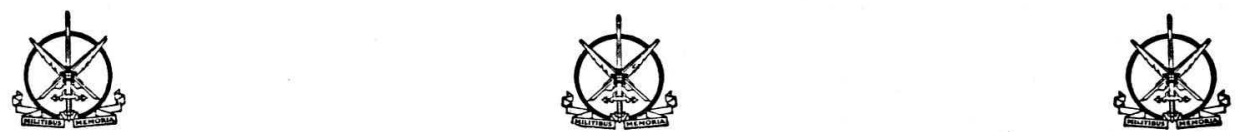


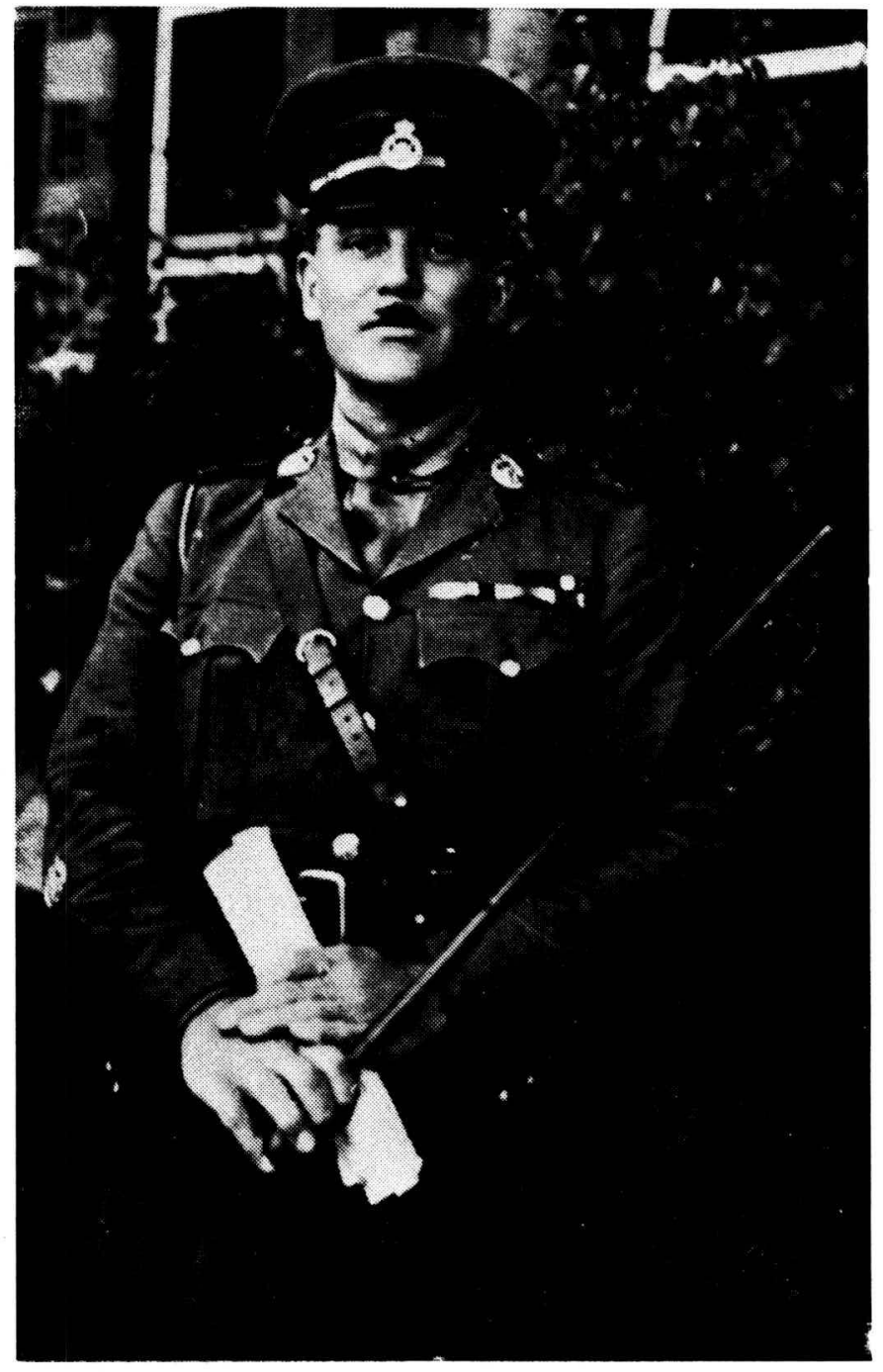

Sersant-majoor L. Higginbotham.

Foto: M.H.A.D. 


\section{DIE NOODSAAKLIKHEID VAN FISIEKE FIKSHEID}

\subsection{Inleiding}

In die voorafgaande hoofstuk is aangetoon dat liggaamlike of fisieke fiksheid een aspek van totale fiksheid is wat uitsluitlik verkry word deur deelname aan 'n georganiseerde program van liggaamlike opvoeding. Hoewel fisieke fiksheid slegs een aspek van totale fiksheid uitmaak, is dit egter as 'n reël die basis waarop emosionele stabiliteit, geestelike sekuriteit en sosiale gesondheid gebou word. In hierdie hoofstuk sal die skrywer probeer om die belangrikheid of noodsaaklikheid van fisieke fiksheid vir sowel die individu as die militêr aan te dui.

\section{2. ' $n$ Veranderde Wêreld}

Die daaglikse bedrywighede van die primitiewe volkere was hoofsaaklik op die bevrediging van die primêre lewensbehoeftes, n.l. die voorsiening van voedsel, huisvesting, kleding, die verdediging en beskerming teen vyande en gevare gebaseer. By die primitiewe mens was daar nie sprake van 'n georganiseerde of doelgerigte stelsel van liggaamlike opvoeding nie. Sy liggaamlike aktiwiteite was ingevleg in die soektogte na voedsel, jag, visvang, die versameling van bessies en die oprigting van skuilings om hulle teen die natuurelemente te beskerm, m.a.w. dit was deel van sy bestaan. Dit was, in die ware sin van die woord, 'n aanhoudende stryd tussen die mẹns in sy primitiewe staat en die oppermagtige natuurelemente.

Die beskaafde mens het hierdie stryd in baie opsigte oorwin: Die klimaatsomstandighede deur doeltreffende kleding en huisvesting, die voedselvoorsiening deur die intensiewe beoefening van landbou, veeteelt en nywerhede, die bewegingsvraagstukke deur die aanwending van meganiese vervoermiddels, die grondbewerking deur arbeidsbesparende masjinerie, gereedskap en sy stryd teen vyandiggesinde medemens deur die toepassing van die wet en in die ergste geval deur wapengeweld. Fisieke inspanning en kragverbruik het in baie gevalle tot 'n groot mate verval en dit het die mens tyd gegee vir waarneming en organisering, m.a.w. die doeltreffende benutting van sy ervaring. Hierdeur het die hedendaagse geordende maatskappy, wat al meer en meer gespesialiseerd raak, ontstaan. In hierdie moderne samelewing word vir bepaalde groepe groter eise aan die geestelike en minder aan die liggaamlike gestel.

Steeds groter getalle werkers word as gevolg van industrialisasie en ander faktore gedwing om hulle daaglikse brood sittende te verdien. Fisiologies is die moderne mense nog net so primitief soos die Kromagnon en hoewel fisieke inspanning tot 'n minimum beperk is, het sy liggaam nog steeds behoefte aan fisieke arbeid. As gevolg van al hierdie faktore bestaan daar 'n behoefte aan 'n beplande program van liggaamlike aktiwiteite om in die toenemende tekort aan liggaamsoefeninge te voorsien, d.w.s. 'n kunsmatige, maar wetenskaplike plaasvervanger vir die oorspronklike primitiewe fisieke arbeid.

\subsection{Vir die Individu}

Die patroon van die aanhoudend veranderde wêreld waarin ons lewe, het grootendeels meegebring dat dit uitsluitlik in tye van oorloë of politieke krisisse is dat daar skielik buitengewone fisieke eise aan 'n volk gestel word en dat daar dan besef word dat liggaamlike fiksheid van die allergrootste belang is $(63: 16)$. 
Wilson $(71: 391)$ wys daarop dat liggaamlike fiksheid fundamenteel is ten opsigte van maksimum doeltreffende industriële produksie en dat dit bydra tot 'n gelukkige en nuttige lewe in enige werkkring waarin die werkende mens geplaas is. Dit geld ook vir 'n Leër, Lugmag en Vloot.

Die American Association for Health, Physical Education and Recreation (26:11) verklaar dat die graad van fiksheid wat deur die mens bereik word die resultaat is van die vermoë om die uiteenlopende en wisselende spanninge van die lewe met meer sukses te oorwin. Optimale fiksheid laat 'n persoon toe om die lewe ten volle te geniet. 'n Fikse persoon kan aan die eise wat sy normale daaglikse take aan hom stel, voldoen en dan nog genoeg energie en lewenskrag oorhou om ontspannende belange te geniet. Hierbenewens is hy in staat om die besondere uitdagings wat in die daaglikse roetine mag opduik die hoof te bied $(26:: 11)$.

Volgens Eisenhardt $(42: 230)$ moet die mens tot die besef gebring word dat hy hom nooit aan aktiewe deelname kan onttrek nie ... dat die lewe aktiwiteit impiiseer en dat individuele fiksheid nasionale fiksheid tot gevolg het. Dit geld in besonder wanneer 'n volk geroep word om sy nasionale erfnisse en voortbestaan in militêre verband te verdedig.

As in aanmerking geneem word dat 'n groot persentasie van die SuidAfrikaanse jeug jaarliks aan militêre diensplig onderworpe is, kry die uitlating van Eisenhardt, n.l. dat indiwiduele fiksheid nasionale fiksheid tot gevolg het, 'n dieper betekenis. Die skoolseun van vandag is immers die militêr van die toekoms.

In die loop van 1962 is die fisieke fiksheidstoetse van die American Association for Health, Physical Education and Recreation aan sowat 3000 Suid-Afrikaanse seuns en dogters aan hoërskole in Transvaal en die Oranje-Vrystaat geadministreer en die resultate vergelyk met dié van dergelike toetse wat in die Verenigde State van Amerika en Groot-Brittanje afgeneem is.

Smit $(84: 16)$ vermeld dat dit uit hierdie toetse duidelik blyk dat die jeug van die Verenigde State van Amerika besonder onfiks is en die die fisieke fiksheid van 'n volk nie volgens die prestasies van sy Olimpiese atlete geoordeel kan word nie.

Dieselfde skrywer wys verder daarop dat die hoë lewensstandaard van die Verenigde State van Amerika met sy veelvoudige krag- en tydbesparende hulpmiddels juis een van die oorsake vir die biologiese verweking is. Hierbenewens verklaar hy dat die liggaamlike opvoedkundiges in alle beskaafde lande bekommerd is oor die toenemende deelname aan passiewe rekreatiewe aktiwiteite soos dic bioskoop, radio, televisie en die toeskouersiekte asook die oormatige gebruik van alle soorte voertuie, hysers en roltrappe in plaas van waar moontlik te stap $(84: 16)$.

In 1962 het Smith $(83: 1-15)$ ook dit uitslae van die Kraus-Weber toetse met Amerikaanse, Oostenrykse, Italiaanse en Switserse kinders vergelyk. Die toetse is dienoorkomstig op 2130 Blanke en 496 Bantoe skoolkinders in Pretoria afgeneem. Smit het bevind dat beide dié groepe beter as die Amerikaanse kinders vertoon het behalwe in die geval van die persentasie swakheid, waar die Bantoekinders swakker as die Amerikaanse kinders vertoon het. Aan die ander hand het die Suid-Afrikaanse groepe, Blank sowel as nie-Blank, swakker as die Oostenrykse, Italiaanse en Switserse kinders vertoon $(83: 4-15)$.

Hierdie resultate dui daarop dat die Suid-Afrikaanse liggaamsopvoeders nie meer so selfversekerd mag wees wat die liggaamlike fiksheid van die SuidAfrikaanse jeug betref nie. 
Benewens bovermelde ondersoek van Smit is daar dikwels in die afgelope dekade in tydskrifte bewerings gemaak dat die Suid-Afrikaanse volk besig is om ..pap" te word (64:14-17 en 34) en dat ons nie fiks is nie (52 en 30).

Ten opsigte van die huidige fiksheidspeil in die geledere van ons eie volk kan die resultate van die Nasionale Fiksheidskema wat in Maart 1968 deur die Melkraad van stapel gestuur is as 'n resente voorbeeld dien. Slegs 19000 SuidAfrikaners het aan hierdie skema deelgeneem. Van die geslaagde inskrywings was 9500 van die gewapende magte afkomstig wat beteken dat die algemene SuidAfrikaanse publiek slegs vir 50\% van die inskrywings verantwoordelik was. Toeligtend is daar dan ook in dié verband verklaar: Surely this indicates that on this important matter of fitness, the average citizen just could not care two hoots (27: 17).

Die ongenoemde skrywer $(27: 117)$ van 'n artikel in die South African Sportsman wys daarop dat daar aanduidings bestaan dat minder as $50 \%$ van ons hedendaagse jeugdiges in Suid-Afrika aan georganiseerde sport deelneem en dat skynbaar weinig meer aan informele liggaamlike aktiwiteite deelneem. Hy meld verder dat byna 200000 jongmense tussen die ouderdomme 16 en 26 jaar aan geen vorm van georganiseerde sport deelneem nie.

Vergelyk in hierdie verband die gegewens wat in 'n ondersoek deur Pieterse (redakteur) $(82: 145)$ vermeld word. In hierdie ondersoek is bevind dat atletiek $(12.9 \%)$, swem $(9.6 \%)$, tennis $(5.1 \%)$ en krekiet $(4.5 \%)$ die belangrikste somersportsoorte is waarvan jeugdiges gedurende hul laaste jaar op skool deelgeneem het. Hierteenoor is rugby $(18.3 \%)$, netbal $(7.9 \%)$, hokkie $(7.0 \%)$ en korfbal $(3.7 \%)$ die belangrikste wintersportsoorte, terwyl tennis die belangrikste deurlopende (somer- en winter-) sportsoort is waarin hulle deelgeneem het.

Hierdie uitsprake en feite is sorgwekkend. Dit is veral merkwaardig dat die simptome wat o.m. vir die verval van die eens so matige Romeinse Ryk verantwoordelik was ook kenmerkend van ons tyd is. Selfmoord, losbandigheid, korrupsie, oneerlikheid, gemaksug en verwywing van mansmense is net 'n paar simptome wat hul verskyning in ons land maak.

Die deelname aan 'n georganiseerde program van liggaamlike opvoeding is nie net essensieel vir die verbetering van liggaamlike prestasievermoë nie, want wetenskaplike navorsing het getoon dat sodanige deelname 'n belangrike bydrae tot die verstandelike ontwikkeling van skoolkinders gelewer het $(28: 21-23)$. Schrecker $(60: 3-4)$ het aangetoon dat gereelde en langdurige liggaamlike opleiding voordelige en blywende invloed op die verstand uitoefen.

In 'n onlangse ondersoek het die President van die Portugese Vereniging van Sportmedisyne, J. Andressen Leitao (58:2), getoon dat die deelname aan liggaamsoefeninge gedurende 'n pouse tydens die werktyd 'n persoon met nuwe werkywer en energie kan besiel. Leitao en sy medewerkers het bewys dat as werkers hul etenstyd benut deur gimnastiek of ander vorms van liggaamsoefeninge uit te voer hul produktiwiteit aansienlik verhoog word en dat minder foute in hul werk voorkom.

Leitao het die proewe met hande-arbeiders, studende en kantoorwerkers geneem en by almal was die uitslag dieselfde: Die werkvermoë van die proefpersone het byna dadelik, nadat met die oefeninge begin is, verbeter en foute in hul werk is tot 'n groot mate uitgeskakel $(58: 42)$. Hierdie bevinding steun die resultate van vroeëre ondersoeke wat in Engeland, Swede en die Verenigde State van Amerika gedoen is. 
Bovermelde feite bewys duidelik dat fisieke en geestelike fiksheid 'n vereiste vir maksimum en doeltreffende werkverrigting in ons moderne, ingewikkelde en sterk geindustrialiseerde samelewing is.

\subsection{Vir die Militêr}

'n Terugblik op die geskiedenis van liggaamlike opvoeding toon dat dié vak deur die eeue heen 'n belangrike rol gespeel het met betrekking tot die voorbereiding van individue vir doeltreffende strydvoering en dat dit ' $n$ kragtige faktor ten opsigte van die vernietiging van 'n vyand geword het $(3: 62)$.

In hierdie verband kan Persië as 'n voorbeeld genoem word. Op die ouderdom van ses jaar is 'n seun deur die staat oorgeneem wat die verantwoordelikheid vir die liggaamlike en militêre opleiding van die seun aanvaar het. Die liggaamlike en militêre opleidingsprogram wat deur die seuns of jong mans gevolg moes word, het grootliks daartoe bygedra dat Persië die doeltreffendste leër van daardie tyd in Asië opgebou het (13:10-12).

In 1804 het die Dene 'n behoefte aan 'n groter en beter opgeleide leër en vloot gehad. Die Deense militêre outoriteite het die waarde van gimnastiek as 'n opleidingsmiddel vir hul gewapende magte besef met die gevolg dat dit 'n essensiële deel van hul militêre opleiding geword het. Die Militêre Gimnastiek Instituut, met Franz Nachtegall as direkteur, is in dieselfde jaar gestig $(13: 114-115)$.

Net soos in die geval van Denemarke het die Swede en die Duitsers ook met deelname aan gimnastiek en liggaamsoefeninge as gevolg van militêre motiewe begin.

Wetenskaplike en statistiese gegewens in verband met liggaamlike fiksheid is ongelukkig bitter skraal as gevolg van die byna algehele afwesigheid van navorsingsondernemings in die Unie-Verdedigingsmag. Tot en met die Eerste Wêreldoorlog (1914-1918), het die ondersoeke byna uitsluitlik tot die soms oppervlakkige geneeskundige ondersoek van rekrute beperk gebly.

Daar sal gepoog word om die belangrike rol wat liggaamlike opvoeding, en dus ook fiksheid, in die militêre voorbereiding van die Amerikaanse en Engelse magte gedurende die Eerste en Tweede Wêreldoorloë gespeel het, te bepaal; terwyl teivens sekere Suid-Afrikaanse militêre statistiese gegewens ter sprake gebring sal word. Vrugtelose pogings is in sekere Europese lande aangewend om gegewens in hierdie verband te bekom.

\subsubsection{Amerika gedurende die Eerste en Tweede Wêreldoorlö̈}

D.c Eerste Wêreldoorlog het die onrusbarende feit aan die lig gebring dit 'n kwari miljoen van die sogenaamde manlike keurgroes wat destyds vir militêre diens in die Amerikaanse magte opgeroep is, nie liggaamlik fiks was nie (44:18).

Die medikus dr. James McCurdy het gedurende dieselfde oorlog as Direkteur van Liggaamlike Aktiwiteite saam met die Amerikaanse en Geallieerde troepe gedien. Hy was ook lid van die American Training Camps Activities Committee. Dr. McCurdy het dic geleentheid gehad om die liggaamlike doeltreffendheid van 'n volle brigade te toets. Gegewens van een regiment het getoon dat $20 \%$ van sy lede nie deur middel van verspring sonder aanloop oor 'n 6 voet wye sloot kon spring nie. Sewentien persent van die troepe kon ook nie die 200 tree naelloop binne 30 sekondes aflê nie (24:198).

In die Amerikaanse militêre lugvaart is bevind dat twee persent van die verliese gedurende die Eerste Wêreldoorlog aan vyandelike optrede, $8 \%$ aan foutiewe vliegtuic en $90 \%$ aan foutiewe menslike organisme toegeskryf kan word 
Een miljoen, of $50 \%$, is vir militêre diens aanvaar, terwyl die ander helfte afgekeur is. Nege honderdduisend, of $45 \%$ van die dienspligtes wat ondersoek is, is op grond van liggaamlike en geestesgebreke afgekeur, terwyl die ander $50 \%$ ongeletterd was $(44: 18)$.

Dic liggaamlike fiksheidspeid van diegene wat wel in die V.S.A. se gewapende magte opgeneem is, dit wil sê die een miljoen wat medies geskik verklaar is, was sodanig dat die eerste 16 weke van die jaar se opleiding (die sogenaamde induction courses) daaraan gewy moes word om hulle fisieke fiksheid op 'n veel hoër peil te bring om aan die eise wat die tegniese opleiding ten opsigte van die toenmalige moderne soldaat gestel het, te voldoen $(47: 133)$.

Statistieke uit die Tweede Wêreldoorlog toon ook aan dat 700000 van die vier miljoen mans wat vir militêre diens in die V.S.A. afgekeur is aan remediële gebreke gely het, wat nie herstel is nie. Baie mans met gebreke is deur die militêre owerhede aanvaar en deur tandartse en geneeshere behandel $(21: 480)$.

Vanselfsprekend was daar nasionale besorgdheid oor die groot getal mans wat vir militêre diensplig afgekeur is. In sommige kringe in die V.S.A. is die blaam vir hierdie toestand aan liggaamlike opvoedingsprogramme in die skole en kolleges toegeskryf.

Ondersoeke na die hoofoorsaak van die groot persentasie afkeurings het ewenwel aan die lig gebring dat liggaamlike opvoeding tot 'n groot mate vrygespreek kan word. Afkeurings op grond van tandheelkundige, visuele en ander gebreke kan nie deur middel van die deelname aan 'n liggaamlike opvoedingsprogram uitgeskakel word nie. $(48: 351)$.

Aan die anderkant, was die kritiek oor liggaamlike opvoeding ook nie heeltemal ongegrond nie. Daar was genoegsame aanduidings dat die toekomstige soldate nie oor die nodige fiksheidspeil beskik het soos openbaar in neuromuskulêre koördinasie, uithouvermoë en krageisende take nie. Hierdie is almal essensiële fiksheidseinskappe wat selfs in die moderne oorlogvoering nog benodig word, want dit is nie slegs die oorlogstuig nie, maar die manskap daaragter wat die deurslaggewende faktor is $(48: 351)$. So is byvoorbeeld gevind dat die manskap nie in staat was om langafstande met swaar uitrusting te stap nie. Hul kon ook nie in die opelug onder ongunstige weerstoestande lewe of vinnig bewegende motorvoertuie oor rowwe terrein bestuur nie.

Forsyth (44:24) verklaar dat Amerikaanse Leër- en Vlootoffisiere gekla het dat hul opleidingsprogramme vertraag en belemmer is deur die fisieke swakheid van die dienspligtiges. Hy meld verder dat die Amerikaanse Leër- en Vlootowerhede aansienlike hoeveelhede geld en tyd aan die genesing van liggaamlike gebreke spandeer het. In hierdie verband noem hy dat die volgende gebreke by mans wat vir diensplig aangeneem is, aangetref is :

1-Swak arm-, skouer- en maagspiere. Sommige rekrute kon nie meer as twee of drie optrekke doen nie.

2-'n Swak houding, altans vanuit 'n militêre oogpunt beskou.

3-Die beenspiere was sterker ontwikkel, 'n verskynsel wat toegeskryf kan word aan die deelname van dienspligtiges aan spierversterkende spele soos voetbal, bofbal, sagtebal, netbal en baanaktiwiteite.

4-Die onvermoë om te swem. Agt-en-twintig persent van die blanke rekrute kon nie 50 tree swem nie, terwyl $80 \%$ van die Negers nie as swemmers kon kwalifiseer nie. 
5---Sommige rekrute het geen kennis van fiksheidsoefeninge gedra en het ook nie geweet hoe om 'n fiksheidspeil te handhaaf nie. Bevindings toon aan dat sommige selfs haat teenoor liggaamsoefeninge gekoester het.

6--Van die rekrute het feitlik oor geen kennis van die lewe in die opelug, kampeer, stap en veldkennis beskik nie.

7-Daar is ook bevind dat sommige rekrute gedurende periodes waarin spele gespeel word, rondstaan omdat hulle nie geweet het hoe om dit te speel nie. Die rede hiervoor moet gesoek word in die feit dat Amerikaanse skole hulle toegespits het op die verbetering van die prestasies van uitblinkers en dat die massa nie die basiese vaardighede van algemene spele geleer is nie $(44: 24)$.

As hierdie gegewens noukeurig ontleed word, is dit duidelik dat die blaam, veral in hierdie opsig op liggaamlike opvoeders geplaas kan word. Krag, uithouvermoë, behendigheid of motoriese vaardighede en ander biologiese mikpunte is unieke doelstellings van die liggaamlike opvoeding, trouens geen ander middel, selfs nie swaar fisiese arbeid kan dit bewerkstellig nie, behalwe liggaamlike inoefening (training) wat op die beginsel van oorlaaiing gebaseer is.

Die Amerikaanse navorser Schroeder $(65: 570)$ is dit eens dat te veel aandag aan die ster-atlete bestee word en dat die aankweek van 'n fiksheidsbesef by Amerikaanse skoliere en studente verwaarloos is.

\subsubsection{Liggaamlike Fiksheid in die Britse Lugmag}

Ook Britse navorsers $(56: 417)$ het aan die einde van die Eerste Wêreldoorlog bevind dat uit elke Britse militêre loods wat in daardie periode gesterf het, 90 dood is as gevolg van tekortkomings wat tot die loods self teruggevoer kan word, m.a.w. die menslike element. Teen die einde van die derde jaar van genoemde oorlog het die aantal van 90 na 12 verminder omdat meer aandag aan die fisieke toestand van die loodse geskenk is. Tewens is hulle nie toegelaat om te vlieg indien hulle in enige opsig liggaamlik onfiks was nie.

Alhoewel die belangrikheid van liggaamlike fiksheid ten opsigte van die opleiding van loodse reeds gedurende die Eerste Wêreldoorlog besef is, was dit nie voor die Tweede Wêreldoorlog nie dat liggaamlike opvoeding op 'n wetenskaplike grondslag in die opleidingsprogramme van loodse ingesluit is. Bucher $(3: 62-63)$ meld dat die doel van dié opleidingsprogramme was om militêre loodse en ander lugvaartpersoneel tot op so 'n hoë fiksheidspeil te bring dat die suksesvolle uitvoering van hul take verseker sou wees.

\subsubsection{Die Unie-Verdedigingsmag}

Lt.-kol. P. C. C. Blair-Hook (29 : 27-28), van die Suid-Afrikaanse Geneeskundige Diens van die Unie-Verdedigingsmag, het in 1939 verklaar dat ondervinding gedurende die Eerste Wêreldoorlog geleer het dat onwetenskaplike en gejaagde oefening duisende manskappe laat beswyk het. Hy skryf hierdie toestand toe aan die feit dat die manskappe of nie in staat was om die strawwe liggaamsoefeninge deur te mak nie of nie behoorlik voorberei was nie en as gevolg van die swaar eise wat aktiewe militêre diens stel, beswyk het. Hy vermeld verder dat ongereelde werking van die hart - 'n algemene term wat 'n aantal harttoestande met soortgelyke simptome insluit, b.v. oordrewe aanduidings van hartvermoeiing - algemeen voorgekom het.

Hy verklaar voorts dat in 1914-1918 nie alleen liggaamlike stremminge soos dié van die hart, voete en ingewande voorgekom het nie, maar senu-aandoeninge sorgwekkende afmetings aangeneem het $(29: 28)$. Twee aspekte tree hieruit 
na vore : Eerstens 'n behoefte aan 'n op militêre lees geskoeide progressiewe program van liggaamlike opvoeding en tweedens, samewerking tussen medici en liggaamlike opvoeding.

Voorts word enkele gegewens, verkry uit jaarverslae van die Departement van Verdediging vanaf 1925 tot 1934, genoem. Mediese ondersoeke het aan die lig gebring dat die volgende persentasie Suid-Afrikaanse dienspligtiges permanent ongeskik vir militêre diens in die Aktiewe Burgermag bevind was : $1925-18.76 \%$; $1926-25.11 \% ; 1927-23.76 \% ; 1928-26.40 \% ; 1929-29.80 \% ; 1930-$ $21.49 \% ;-1931-22.46 \% ; 1932-24.41 \% ; 1933-16.57 \%$ en $1934-20.50 \%$.

By die bestudering van hierdie gegewens blyk dit dat die hoogste persentasie afkeurings in 1929 met $29.80 \%$ voorgekom het, terwyl in 1933 slegs $16.57 \%$ van die voornemende dienspligtiges nie aan die vereiste mediese standaarde kon voldoen nie. Bovermelde verslae het ook aan die lig gebring dat die hoofoorsake van afkeurings die volgende behels het: Kwale van die senuwees (verlamming, vallende siekte, swaksinnigheid, e.d.m.), lugpyp (asma, myntering, swak bors, e.d.m.), spysverteringsorgane, uitskeidingsorgane, geslagsorgane, bewegingsorgane, (gebeente, gewrigsontsteking, stywe ledemate, verlies van ledemate, gebreke aan arms en bene met inbegrip van platvoete), swak oë en oorkwale, ongereeldhede van die hart, swak liggaamsbou en slegte tande.

Hierdie oorsake, veral dié ten opsigte van kwale van die bewegingsorgane, swak liggaamsbou en platvoete toon aan dat 'n geïntegreerde en doeltreffende program van liggaamlike opvoeding 'n waardevolle bydrae kon lewer om die persentasie afkeurings te verminder.

Slegs enkele navorsers het ondersoeke m.b.t. liggaamlike fiksheid in die Suid-Afrikaanse militêre organisasie gedoen.

In 1967 het De Lange (86:92 en verder) 'n ondersoek voltooi waarin bevind is dat skoolseuns uit matriek nie onfikser is as die rekruut wat sy driemaande basiese opleiding in die Weermag voltooi het nie. Hy het verder ook bevind dat die basiese opleiding van 3 maande van die Weermag geen betekenisvolle bydrae tot die bevordering van die fisieke fiksheid van die rekruut uit matriek lewer nie.

Hierdie bevinding van De Lange, nl. dat bogenoemde basiese opleiding van die Weermag geen betekenisvolle bydrae tot die bevordering van die fisieke fiksheid van die rekruut uit matriek lewer nie, word deur Scholtz $(89: 204-205)$ weerlê. Laasgenoemde navorser het bevind dat die basiese opleiding van die Suid-Afrikaanse Weermag en die opleiding van die Suid-Afrikaanse Polisiekollege met betrekking tot fisieke fiksheid 'n sterk positiewe bydrae tot die bevordering van fisieke fiksheid lewer.

Scholtz het voorts tot die gevolgtrekking gekom dat daar 'n verontrustende daling in die fiksheidspeil van Suid-Afrikaanse blanke seuns is sodra hulle die skool verlaat. Hierdie daling is van so 'n aard dat, wanneer hulle vir militêre of polisieopleiding aanmeld, 'n basiese fiksheidskondisionering absoluut nodig is (89:205).

Die rede vir die daling van die jong Suid-Afrikaners se fiksheidspeil kan gesoek word in die leefwyse van die blanke en dit hou 'n bedreiging in vir die werkvermoë, produktiwiteit, gesondheid en weerbaarheid van die volk. 


\subsubsection{Fiksheidsvereistes vir 'n Lugmag}

Terwyl daar min of geen fisieke krag by die loods van 'n gewone vliegtuig vereis word nie, is maksimum liggaamlike fiksheid en koördinasie van die uiterste belang by die loods van 'n vliegtuig tydens gevegshandelinge. Dit is noodsaaklik omdat die loods akkurate besluite in 'n breukdeel van 'n sekonde moet neem en hulle oombliklik moet uitvoer. Die gevaar bestaan ook dat lugmagmanne, net soos in al die vertakkinge van die verdedigingsorganisasie, geïsoleer kan word en op hulleself aangewese is. Lugmagpersoneel wat oor vyandelike terrein afgeskiet word, moet krag en uithouvermoë besit om hulle pad na hulle eie magte oor somtyds moeilik begaanbare terrein te vind $(57: 371)$.

Bucher $(3: 63-65)$ noem sewe punte wat tot 'n mate aandui waarom liggaamlike opvoeding noodsaaklik is vir lede van die militêre lugvaart:

1 -Die loods van 'n vliegtuig is primêr 'n liggaamlike vaardigheid.

2-Dit dra daartoe by om 'n gevoel vir balans te ontwikkel.

3-Dit ontwikkel spiere van die nek, skouers, arms en in die maagstreek.

4-Dit ontwikkel wakkerheid van gees en ander noodsaaklike vermoëns.

5-Dit ontwikkel spangees en bevorder die vermoë om saam te werk.

6-Oefeninge en ontspanning wat deur die deelname aan liggaamlike aktiwiteite vrygestel word, het 'n positiewe algemene higiëniese uitwerking.

7-Dit dra by om selfvertroue te ontwikkel.

\subsubsection{Fiksheidsvereistes vir 'n Leër}

Die Amerikaner Weible $(70: 128)$ het daarop gewys dat moderne oorlogvoering só tegnies van aard is dat $90 \%$ van die soldate take verrig waarby gespesialiseerde opleiding en vaardighede vereis word. Loodse moet vliegtuie hanteer wat alleen in die lug gehou kan word deur die doeltreffende funksionering van honderde bedrewe tegnici. Van soldate word vereis om reuse tenks en voertuie oor enige soort terrein te kan bestuur. Die reuse masjiene en draaiende torings bied op hul beurt 'n groter uitdaging aan die vaardigheid van die hoogs bevoegde tegnici. Die vegsman moet ook wapens afvuur waarvan die spoed en akkuraatheid deur meganiese en elektriese instrumente beheer word.

Met inagneming van hierdie feite is dit duidelik dat groot eise aan die krag, uithouvermoë, spoed en behendigheid van die soldaat gestel word.

Die bewering of vermoede dat met die meganisering van oorlogvoering die fisieke fiksheid van die soldaat minder belangrik is as in die verlede word deur die alledaagse ervaring in die moderne tegnologiese beskawing weerlê. Die verskynsels van die toenemende spanning ( $E$ Stress) kan deur die deelname aan liggaamlike aktiwiteite afgeweer word.

Laasgenoemde bewering word deur Larson (50:144) gesteun wat daarop wys dat moderne oorlogvoering ' $n$ geweldige spanning op die menslike liggaam plaas. Hierdie spanning word onder gevegshandelinge, ongunstige klimaats- en swak higiëniese toestande verhoog.

Hein en Ryan (46:263-279) het bevind dat benewens oorgewig, foutiewe dieet, rook en 'n gebrck aan geskikte oefeninge, emosionele spanning uitgesonder kan word as 'n faktor wat siekte van die kroonslagaar tot gevolg het.

Selye (17: 109 en verder) glo dat chemiese wanbalans in die liggaam, wat deur druk ( $E$ Stress) veroorsaak word, die oorsaak vir die meeste siektes is. 
Volgens hom word die reaksie op druk beheer deur die slymklier net onderkant die brein en die twee byniere net bo-op die niere. Die hormone wat hulle afskei, beveg die drukking of spanning, maar waar hulle gedurig onderwerp word aan voortdurende druk soos gejaagdheid, bekommernis, e.d.m. moet die kliere meer en meer hormone afskei totdat die verdedigingsmeganisme uiteindelik ineenstort, met die gevolg dat hoë bloeddruk, verharding van are, hartsiektes en gewrigontsteking ontwikkel.

Ondanks die groot vooruitgang op die gebied van die geneeskunde, berowe die moderne tegnologiese ontwikkeling die mens van noodsaaklike liggaamlike aktiwiteite.

In 'n onlangse studie het $\mathrm{Du}$ Toit $(51: 9-15)$ aangetoon dat oefening belangrik is m.b.t. die rehabilitasie van hartpasiënte.

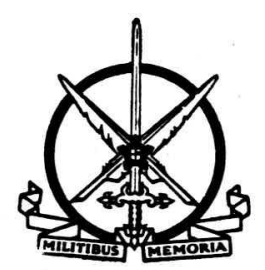

Samevatting

Die doel van liggaamlike opvoeding in enige verdedigingsorganisasie is om 'n hoë peil van fiksheid daar te stel en te behou en om die gesondheidstoestand van indiwidue te bevorder. Hierdeur sal sy werkvermoë en doeltreffendheid verbeter word. Die ontwikkeling van selfbeheer, selfvertroue en ondernemingsgees is 'n natuurlike uitvloeisel van enige geïntegreerde program of skema van liggaamlike opvoeding. Hierdie hoedanighede is in enige verdedigingsorganisasie van groot waarde vir die bevordering van geestelike en emosionele fiksheid wat gewoonweg die moreel genoem word.

Vermoeidheid, swakheid en fisieke uitputting word gewoonlik met 'n lae moreel geassosieer.

Die basis van ' $n$ weermag se effektiwiteit is in die eerste plek sy menslike materiaal. Die gehalte van die individuele soldaat bepaal die standaard van ' $n$ weermag. Die geskiedenis het ook getoon dat 'n weermag wat liggaamlik, geestelik en sedelik gestaal en geïnspireerd is, onoorwinlik met die nodige toerusting is. 


\section{4. 'N KORT OORSIG OOR DIE ONTSTAAN EN ONTWIKKELING VAN DIE UNIE-VERDEDIGINGSMAG TOT 1946}

\subsection{Inleiding}

Sedert die vroegste tye is dit die strewe van die mens om sy lewe, sy besit, die stoflike en ander belange te beskerm, al moet die wapen ook vir daardie doel opgeneem word.

Hierdie beskermingsdrang kom ook tot uiting in 1652 se stigtingsdaad aan die Kaap. Kommandeur Jan van Riebeeck moes 'n fort bou en ander verdedigingsmaatreëls tref om die kolonie teen binne- en buitelandse invallers te beskerm.

Uit die stigting van 'n verversingspos aan die Kaap het 'n nuwe volk gegroei wie se strewe deur die eeue heen steeds gebly het om te beskerm en te behou wat hulle besit. Vandag is dit nog steeds die geval.

\subsection{Die Kaap onder die Verenigde-Oos-Indiese Kompanjie 1652-1795}

Die voorgeskiedenis van die Unie-Verdedigingsmag begin met die stigting van die blanke volksplanting aan die Kaap in 1652 .

Jan van Riebeeck en die Breë Raad het reeds aan boord van die Drommedaris namens die Here XVII 'n reglement vir soldate en matrose, tesame met die instruksies in verband met die bou van die fort, uitgevaardig $(76: 1)$.

Aan die Kaap het 'n klein blanke nedersetting tot ontwikkeling gekom. Die handelsbelange wat hierdie klein nedersetting verteenwoordig het, moes teen binnelandse invalle en buitelandse mededingers beskerm en verdedig word.

Aanvanklik was dit die taak van die Kompanjiesdienare, maar reeds ses jaar na Van Riebeeck se aankoms in 1652, is al die weerbare vryburgers in 'n skutterskompanie ingedeel $(75: 1)$.

Die Vryburgers en hul nasate het die binneland begin verken en hulle daar gevestig. Dit het tot gevolg gehad dat die burgermilisiestelsel met sy beginsel van persoonlike diensplig, met langsaan die stelsel van huurtroepe, tot ontwikkeling gekom het. Mettertyd sou eersgenoemde 'n tradisie in ons militêre geskiedenis word $(76: 2)$.

Die groeiende nedersetting het stadigaan sy grense noord- en ooswaarts begin verskuif met die boer op die voorpunt. Hierdie steeds wykende grense het die probleem van groterwordende afstande vir die voetvolkmilisie teweeggebring wat op een of ander manier oorbrug moes word. Die antwoord op hierdie vraag was die perderuiters, ofskoon die burgers aanvanklik die keuse gegee is om by die infanterie (voetvolk) of by die kavallerie (ruitery) aan te sluit $(76: 2)$.

In die buitedistrikte het die kommandostelsel, wat later so 'n groot rol in ons eie verdedigingstelsel sou speel, 'n bloeitydperk begin beleef. Dit het na verloop van tyd die belangrikste weerbare organisasie in die kolonie geword en sou, tydens die Groot Trek en gedurende die bestaan van die Boererepublieke, sy hoogtepunt in ons militêre organisasiewese en militêre geskiedenis bereik $(76: 2)$.

Offisiere is uit eie geledere gekies, kommandolede is deeglik geskool in 
Die Kaapse Garnisoen, wat in diens van die Kompanjie was, se eerste verantwoordelikheid het gelê in die beskerming van die belange van die Kompanjie. Die kommandolede, aan die anderkant, was by uitstek geestelik en andersins daarop ingestel om hul eie belange te verdedig en hulleself as 'n wordende nasie te handhaaf $(76: 2)$.

Van Riebeeck het 'n beleid van vreedsame naasbestaan met die inboorlinge nagestreef, maar die toenemende astrantheid van en wrywing met die Hottentotte het militêre optrede nodig gemaak. Hierdie optrede het in 1659 begin en in 1660 het die Hottentotte om vrede gevra (22:353-354).

Die vrede was egter nie blywend nie, want in 1673 en 1674 is kommando's weer uitgestuur om die Hottentotte te straf. Hierdie kommando's was hoofsaaklik regeringskommando's (22:353-354).

Vervolgens het die rowery van die Boesmans die regering verplig om maatreëls ter verdediging van die kolonie te tref. In 1715 is die eerste kommando, wat uitsluitlik uit burgers saamgestel was, uitgestuur om die vee van die Boesmans terug te neem $(22: 365)$. Dit was die begin van 'n nuwe ontwikkelingsfase, t.w. dat hierdie soort kommando die bestaande regeringskommando's geleidelik begin verdring en vervang het.

Kommando's het ook in 1779-1781 en in 1789-1793 aan die Kaapse oosgrens teen die Bantoe opgetree $(20: 30)$.

In die tweede helfte van die $18 \mathrm{de}$ eeu was die Nederlandse Republiek vinnig aan die agteruitgaan. Die gees van die Franse Revolusie het ook tot die Nederlanders deurgedring en spoedig was die volk in twee kampe verdeel, nl. die Patriotte en die Oranje-ondersteuners. Die besetting van die Nederlandse Republiek deur die Franse magte in Desember 1794 het daartoe gelei dat die Prins van Oranje op 18 Januarie 1795 na Engeland vlug $(18: 171)$ waar hy die Engelse regering gevra het om die Nederlandse koloniale besittings in tydelike bewaring te neem. Daar het vrees bestaan dat die Franse ook die Kaap sou verower en 'n bedreiging vir die Britse handel met die Ooste sou word. Die stuur van skepe om die Kaap te beset, was dus 'n saak van eiebelang vir Engeland, sowel as die nakoming van 'n belofte wat aan die Prins van Oranje gegee is $(15: 71)$.

Op 11 Junie 1795 het 'n Britse vloot van ses skepe en vier ander vaartuie in Valsbaai aangekom onder bevel van adm. G. K. Elpinstone (15: 77).

Die verdediging aan die Kaap het nie aan die verwagtings voldoen nie, Sluysken het 'n regiment voetvolk van sowat 25 offisiere en 546 manskappe onder bevel van lt.-kol. De Lille, 'n korps artillerie van 27 offisiere en 40 manskappe en die Pandoer-korps van 210 man sterk, almal onder aanvoering van kol. R. J. Gordon, tot sy beskikking gehad. Hierdie mag is deur 1140 berede burgers uit dit buitedistrikte en 340 man voetvolk uit Kaapstad aangevul. Die Engelse mag het uit tussen vier- en vyfduisend goed gewapende soldate bestaan.

Dit Patriotiese burgers het, veral na die lafhartige gedrag van lt-kol. De Lille, hul vertroue in die leërleiding verloor en het uiteindelik mismoedig huis toe begin gaan. 'n Steeds inkrimpende en retirende mag onder kol. Gordon moes spoedig die vlag vir die Engelse stryk (22:185-186).

Met die eerste formele oorgawe van die Kaap aan die Engelse op 16 September 1795 het die gesag van Nederland aan die suidpunt van Afrika tydelik verdwyn.

Na die oorname van die Kaap het 'n Britse mag onder bevel van genl.maj. James Craig agter gebly om die kolonie te beskerm. Dit het uit 2928 man en 'n paar skepe bestaan $(19: 6)$. 
Op 1 Maart 1803 is die kolonie aan sy vorige eienaar teruggegee. Op dieselfde dag is lt.-genl. Janssens deur Kommissaris De Mist as goewerneur aangestel $(19: 118)$.

Die Kaap het egter nie in besit van sy oorspronklike eienaars gebly nie. Op 4 Januarie 1806 het 61 Britse skepe hulle verskyning aan die horison gemaak. Die Britte, onder aanvoering van genl. Baird, het oor 'n strydmag van ruim 4500 man beskik $(22: 219)$.

Hierteenoor moes Goewerneur Janssens die Kaap met 'n mag van ongeveer 2000 man saamgestel uit burgers, Hottentote en Javane, verdedig $(22: 219)$.

Dit uitslag van die botsing by Blaauwberg op 8 Januarie 1806 was te voorsien. Twee dae later het Kaapstad geval en op die 18de Januarie 1806 het Janssens met die oorskot van sy leër, wat na die Hottentots-Hollandberge teruggewyk het, gekapituleer $(22: 220)$.

\subsection{Die Kaapkolonie onder Britse Beheer}

$\mathrm{Na}$ die tweede oorname van die Kaap deur die Britte is die bestaande kommandostelsel in sy geheel oorgeneem $(20: 3)$. Die invoering van die Britse militêre sielsel van gereelde troepe en vrywilligereenhede as grondslag het daartoe bygedra dat die kommando's geleidelik hul invloed in die Britsbeheerende Kaapkolonie begin verloor het. Dit was veral sir George Grey, wat die dringende noodsaaklikheid besef het om die verdedigingsorganisasie aan die Kaap te versterk, en die geleentheid benut het om die vrywilligerstelsel aan die Kaap in te voer (76:3).

Een van die oudste op Britse militêre lees geskoeide vrywilligerskorpse in die Kaapprovinsie, die Cape Town Rifles, het in 1855 sy verskyning gemaak $(20: 58)$. Behalwe dat vrywilligereenhede in die Kaapkolonie tot stand gekom het, het gereëlde troepe uit Engeland hul weg na die Kaap gevind; 'n toestand wat selfs nadat die Unie-Verdedigingsmag tot stand gekom het m.b.t. die Kaapse Skiereiland tot 1921 sou voortduur.

In die Kaapkolonie het die vrywilligers en die Britse eenhede saam geveg, terwyl die Cape Mounted Riflemen - die eintlike koloniale Staande Mag - veral polisiedienste in die Oostelike Provinsie verrig het $(20: 58)$. Die Britse magte het veral aan die Kaapse oosgrens vanaf 1811 tot in die 4de, 5de en 6de Grensoorloë opgetree $(20: 30)$.

Bogenoemde bekende eenheid het in 1858 as die Frontier Armed and Mounted Police begin om later in 1878 tot die Cape Mounted Riflemen omskep te word. Die bevelvoerder van hierdie mag het die titel van kommandant-generaal besit en in 1895 het hy die rang van kolonel gekry $(76: 5)$.

$\mathrm{Na}$ die Anglo-Boereoorlog is die Cape Mounted Riflemen se offisiere met die opleiding van die Kaapse vrywilligereenhede belas. gesien :

Die Kaapse militêre organisasie het voorheen dus soos volg daaruit

1. Aan dic hoof van die Departement van Verdediging het kol. H. T. Lukin, C.M.G., D.S.O., kommandant-generaal van die Kaapse Verdedigingsmag, gestaan.

2. Die mediese afdeling het It.-kol. G. Knapp as hoof gehad.

3. Die Krygsbehoefte Afdeling was gevestig op Kingwilliamstown, Kaap- 
4. Kol. H. T. Lukin was bevelvoerder van die Cape Mounted Riflemen. Hy het oor sy eie staf beskik wat o.m. 'n artillerie-instrukteur, 'n kwartiermeester, 'n betaalmeester en 'n geneesheer getel het.

5. Die Cape Mounted Police het onder kommissaris M. B. Robinson, C.M.G., gestaan. Dan was daar ook nog lede van die uitvoerende en administratiewe takke $(76: 6)$.

Die Staande Mag van die Unie-Verdedigingsmag het, ooreenkomstig die bepalings van die Verdedigingswet van 1912, sy verskyning op 1 April 1913 gemaak. Die Cape Mounted Rifles het ook op dié dag, as die eerste Regiment ZuidAfrikaanse Bereden Schutters (South African Mounted Rifles), sy dienste as ' $\mathrm{n}$ deel van die Unie-Verdedigingsmag voortgesit. Die bestaande Kaapse Vrywilligeren kadetorganisasies het op 1 Julie 1913 ontbind en is deur die landsomvattende Aktiewe Burgermag (A.B.M.) en 'n nuwe kadetorganisasie vervang $(76: 6)$.

\subsection{Die Boererepublieke tot 1899}

\subsubsection{Natal}

Die geskiedenis van die georganiseerde verdediginstelsel van Natal begin met die kortstondige bestaan van die Voortrekkerrepubliek Natalia (1840-1843).

Die tradisionele kommandostelsel het as grondslag vir hierdie Voortrekkerverdedigingstelsel gedien. Die gebied is in distrikte en wyke ingedeel. Elke wyk het onder 'n veldkornet ingeskakel, elke distrik onder 'n kommandant en hulle was op hulle beurt weer verantwoordelik aan 'n kommandant-generaal wat geen vaste pos beklee het nie, maar slegs in geval van oorlog sou optree $(76: 6)$.

Nadat Brittanje dié gebied in 1843 geannekseer het, het die verantwoordelikheid vir die verdediging daarvan by die Britse regering berus.

In Natal, onder Britse koloniale bewind, het die vrywilligerorganisasies, ongeveer gelyktydig met dié in die Kaapkolonie hulle verskyning gemaak. Eenhede soos die Natal Field Artillery, wat aanvanklik in 1954 as 'n kompanie van die Durban Volunteer Guard begin en in 1892 eersgenoemde naam ontvang het, het in Natal ontstaan $(20: 119)$.

Ander eenhede wat tot stand gekom het, was o.m. die Royal Natal Carbineers (1855) en die Victoria Mounted Rifles (1862).

Die Natal Mounted Police het in 1874 as die enigste gereëlde koloniale mag in Natal tot stand gekom. Die bevelvoerder van hierdie organisasie het tot 1895 beheer oor die vrywilligereenhede uitgeoefen. In hierdie jaar het die Natalse regering, as 'n uitvloeisel van die toekenning van verantwoordelike bestuur aan die kolonie in 1893, geleidelik die verantwoordelikheid vir die verdediging van die grondgebied oorgeneem $(76: 6)$.

Dis Verdedigingswet van 1912 het die einde van die ontwikkelingsgang van die verdedigingsorganisasie van Natal beteken.

\subsubsection{Die Oranje-Vrystaat}

Die Voortrekkers het die Kaapkolonie in die dertiger jare van die vorige ceu verlaat op soek na vryheid en onafhanklikheid en met die bereidheid om hul toekomstige statestigtings, indien nodig, met die wapen te verdedig. Die OranjeVrystaat het in 1854 sy staatkundige onafhanklikheid verkry. Hierdie Boererepubliek het nou geleentheid gehad om sy verdedigingstelsel op en uit te bou. Dic tradisionele kommandostelsel het die grondslag vir hierdie Republikeinse verdedigingstelsel gevorm. 
Ploeger (76:8) wys daarop dat daar in die grondwet van die OranjeVrystaat verklaar is dat alle burgers van 16 jaar en almal wat op latere leeftyd burgerreg verkry het, tot hul 60ste lewensjaar onderworpe was aan burgerdiens.

Die president van die Oranje-Vrystaat het in tye van oorlog oor 'n kommandant-generaal, wat meestal 'n hoofkommandant genoem is, beskik. Die hoofkommandant is op sy beurt weer deur veldkommandante, veldkornette en hul ondergeskiktes bygestaan $(76: 8)$.

Die Vrystaatse regering het na die verkryging van onafhanklikheid in 1854 onverwyld aandag aan die verdediging gegee. Die eerste Kommandowet is reeds in Mei 1854 gepubliseer.

In 1876 is die artilleriekorpsregulasies uitgevaardig en vier jaar later het die korps uit 'n adjudant, 'n luitenant, 'n sersant, 'n onderwyser, 'n kapel- en 'n betaalmeester en hoogstens 'n dosyn artilleriste bestaan. Benewens hierdie Staande Mag het die Oranje-Vrystaat ook in die sestiger jare en van 1889-1896 oor die Rijdende Dienstmacht beskik wat aanvanklik, los van die Artilleriekorps, onder bevel van kapt. Albrecht gestaan het $(76: 10)$.

Hierdie organisasie, wat tot 3 sersante, 6 korporaals en 81 manskappe uitgegroei het, is in 1896 onder die Vrystaatse Kommissaris van Polisie geplaas en was hoofsaaklik met polisie- en patrolliewerksaamhede belas.

Vanaf 11 Oktober 1899 sou die Vrystaatse magte saam met Transvaal aan die Anglo-Boere-oorlog deelgeneem.

\subsubsection{Die Zuid-Afrikaansche Republiek 1852-1899}

Die Voortrekkers in die Oorvaalse gebied het hul staatkundige onafhanklikheid kragtens die Sandrivierkonvensie in 1852 verwerf, maar reeds so vroeg as 1844 is daar in die Drie-en-Dertig Artikels, 'n soort grondwet, wat op Potchefstroom opgestel en op 23 Mei 1849 op Derdepoort goedgekeur is, neergelê dat elke kommandant, veldkornet of assistent-veldkornet van die gewapende magte wat na wettige oproeping deur die Raad of burgerlike gesag sou weier om sy wetlike militêre verpligtings na te kom, die reg kon uitoefen om weieraars met geldboetes of tronkstraf te straf $(76: 11)$.

In die Transvaalse grondwet van 1958 is o.m. verklaar dat die krygsmag uit alle weerbare mans tussen 16 en 60 jaar sou bestaan. Ook binnelandse kleurlinge sou in die kommandostelsel ingeskakel word. Die Zuid-Afrikaansche Republiek het later ook oor sy Staande Mag, die Staatsartillerie, beskik (20:185). Die artilleriekorps het oor 'n bevelvoerder met die rang van luitenant-kolonel beskik en was in die negentiger jare soos volg saamgestel: Die artillerieafdeling bestaande uit rydende-, berg- en vestingartillerie; die veldtelegrafie; die kommissariaat; die musiekkorps; die geneeskundige afdeling; onderwyspersoneel; 'n smidswinkel en 'n draaiersafdeling (76:14).

Ook hierdie Republikeinse magte het in 1899 die wapen opgeneem om in 'n driejarige worsteling hul heiligste besit te verdedig.

\subsection{Die Anglo-Boereoorlog 1899-1902}

Besonderhede oor die verloop van hierdie oorlog kan o.m. in die volgende werke nagegaan word: Maurice, F., History of the War in South Africa, London, Hurst and Blackett Limited, 1906, 4 bande; Breytenbach, J. H., Die Tweede Vryheidsoorlog, deel I : Voorspel tot die Stryd, deel II : Ontplooiing van die Boereoffensief, Oktober 1899, Kaapstad, Nasionale Pers Beperk, 1948 en 1949; Muller, 
C. F. J., Vyfhonderd Jaar Suid-Afrikaanse Geskiedenis, Pretoria en Kaapstad, Academica, 1968; Breytenbach, J. H., Die geskiedenis van die Tweede Vryheidsoorlog in Suid-Afrika 1899-1902, Pretoria, Die Staatsdrukker, 1969 (pp. 508).

Die Tweede Vryheidsoorlog het as gevolg van staatkundige en politieke verskille tussen die regerings van die Boererepublieke en Brittanje op 11 Oktober 1899 uitgebreek.

Die Boeremagte, 'n ware volksleër, was saamgestel uit kommando's van Transvaal en die Vrystaat, gereelde eenhede van die Transvaalse Staatsartillerie en die Vrystaatse artillerie en die Transvaalse Polisie (Z.A.R.P.). Hierdie magte het uit ongeveer 60000 man bestaan.

Aan die anderkant het die Britte oor goed opgeleide en gewapende gereelde troepe sowel as eie en koloniale vrywilligereenhede beskik. Met die verloop van die stryd het die Britte bykans 'n kwart miljoen man in die veld gehad. Aanvanklik was genl. Buller die opperbevelhebber van die Britse Magte.

Die Boere-offensief is aan drie fronte van stapel gestuur:

1. Aan die wesfront het genl. P. A. Cronje Mafeking en Kimberley beleër. In November 1899 het lord Methuen probeer om Kimberley te ontset. Die Boeremagte is by Belmont, Graspan en Modderrivier teruggeslaan, maar by Magersfontein is Methuen 'n gevoelige nederlaag toegedien.

2. In die suide het die Boeremagte die Oranjerivier oorgesteek waar genl.-maj. Gatacre op 10 Desember 1899 in die Stormberge verslaan is.

3. Aan die oosfront het genl. P. J. Joubert vir Penn-Symons by Dundee 'n nederlaag toegedien, maar by Elandslaagte was die uitslag die teenoorgestelde. Genl.-maj. White het pogings aangewend om die Boeremagte by Modderspruit en Nicholsonsnek terug te dryf, dog hy kon nie daarin slaag nie.

Daarna het die beset van Ladysmith gevolg. Die Boere-offensief het by Estcourt doodgeloop en genl. Joubert het tot op die Tugela teruggetrek.

Genl. Louis Botha het, na genl. Joubert se dood, die bevel oor die Boeremagte oorgeneem.

Genl. Buller het by Colenso probeer om Ladysmith te ontset, maar die poging het misluk. Op 24 Januarie 1900 is 'n tweede poging by Spioenkop afgeweer en die derde by Vaalkrans het ook nie geslaag nie.

Die Britte se eerste strategiese plan was om die Britse troepe in Ladysmith te ontset en die burgerkommando's te vernietig.

$\mathrm{Na}$ die mislukte aanslae op die Republikeinse magte het die Britse leërleiding versterking ontbied, waarna lord Roberts die opperbevel van genl. Buller oorgeneem het.

Op 15 Februarie 1900 is Kimberley deur genl. French ontset en het genl. lord Kitchener die Vrystaat met 'n sterk afdeling kavallerie binnegetrek. Genl. Cronje was verplig om van Magersfontein terug te trek en op Paardeberg moes hy op 27 Februarie 1900 met 4000 burgers oorgee. As gevolg van hierdie oorgawe moes die verswakte Boeremagte terugval en op 13 Maart 1900 is Bloemfontein ingeneem.

Op 1 Maart 1900 het genl. Buller daarin geslaag om Ladysmith na hewige gevegte by Pietersheuwel te ontset.

Die Britte se tweede strategiese plan het daarop neergekom dat die kommando's sal oorgee as die Republikeinse hoofstede beset is. 
Genl. Christiaan R. de Wet kon met sy guerilla-taktiek nie verhoed dat die opmars van Roberts en Kitchener van Bloemfontein na Pretoria voortgesit word nie. Johannesburg het op 31 Mei 1900 in vyandelike hande gekom en Pretoria het op 5 Junie van dieselfde jaar geval.

$\mathrm{Na}$ die verowering van die twee hoofstede was daar sprake van vrede, maar die onderhandelings tussen genl. Botha en veldmaarskaik lord Roberts het misluk. Laasgenoemde het die Vrystaatse en Transvaalse republieke geannekseer en dié gebiede is as die Orange River Colony en die Transvaal Colony geproklameer. Lord Kitchener het hierna bevel oor die Britse magte oorgeneem.

Die oorlog was egter nie iets van die verlede nie. Genl. de Wet, die man wat die guerilla-taktiek begin toepas het, het in die Vrystaat suksesse teen die vyand behaal en genl. De la Rey het dieselfde in Wes-Transvaal gedoen. In OosTransvaal het genl. Louis Botha self die leiding geneem, terwyl genl. C. F. Beyers die stryd in Noord-Transvaal voortgesit het. Die stryd is selfs in die Kaapkolonie onder bekwame militêre leiers soos Smuts, Maritz, Malan, Kritzinger, Scheepers en Lategan aangeknoop.

Teen die einde van 1900 het die Britse leërleiding besluit om sy taktiek te wysig. Blokhuis en doringdraadversperrings, wat moes dien as beskerming van die spoorweë en om burgerkommando's teen vas te keer, is opgerig.

Toe hierdie taktiek onsuksesvol blyk te wees, het die Britte met 'n uitputtingsoorlog begin wat daarin bestaan het dat die Boere se kosvoorrade opgeruim moes word. Boerehuise is afgebrand, tuine en landerye verwoes en selfs veetroppe is vernietig. Vroue en kinders is in konsentrasiekampe geplaas en krygsgevangenes is na St. Helena, Bermuda en ander kampe gestuur.

Die burgers het aanhou veg, maar was nie teen die Britse oormag opgewasse nie. Op 31 Mei 1902 het die sluiting van vrede van Vereeniging op Pretoria gevolg.

\subsection{Die jare 1902-1912}

Die belangrikste ontwikkeling met betrekking tot verdedigingsake in Natal was die vervanging van die bestaande wet deur die Milisiewet in 1903 (75:7). Hierdeur sou Natal nou oor 'n verdedigingstelsel beskik wat deur loting aangevul kon word indien dit nodig sou blyk te wees.

Die verdedigingswet van 1912 het die einde van die ontwikkelingsgang van die verdedigingsorganisasie van Natal beteken.

Die Oranje-Vrystaat het na die Anglo-Boereoorlog 'n deel van die Imperiale besettingsmagte behou. In die stormagtige oorlogsjare het die verdedigingsorganisasie van die Oranje-Vrystaat verdwyn en die Britse South African Constabulary het sy verskyning in ons militêre geskiedenis gemaak. Die hieropvolgende Britse vrywilligerstelsel het nie ingang in die Oranjerivier-kolonie gevind nie.

In teenstelling met die Vrystaat het vrywilligereenhede, geskoei op die Britse lees, in Transvaal ontstaan. Berede vrywilligereenhede soos die Imperial Light Horse, die South African Light Horse e.a. is gestig. Teen 1908 het, benewens die berede vrywilligers, ook artilleriste, infanteriste, lede van die genie, telegrafiste en seiners hul verskyning as deel van die Transvaal Volunteers gemaak (76:14).

Die Unie van Suid-Afrika het in 1910 tot stand gekom met genl. Louis Botha as Ferste Minister. Een van die belangrikste take van die nuwe kabinet was om aandag te gee aan 'n nuwe verdedigingsorganisasie. 
Genl. J. C. Smuts het op 31 Mei 1910 o.a. die portefeulje Verdediging begin beheer. Tot op 1 Julie 1912 is die administrasie m.b.t. verdedigingsaangeleenthede deur 'n tak van die Departement van Binnelandse Sake behartig, terwyl vanaf laasgenoemde datum die Departement van Verdediging as 'n selfstandige departement begin funksioneer het $(76: 17)$.

Die grondslag vir die Unie-Verdedigingsmag (U.V.M.) is gelê toe die wetsontwerp, wat voorsiening mak vir die verdediging van die Unie en sake wat daarmee in verband staan. op 30 November 1911 in 'n Buitengewone Staatskoerant afgekondig is (73).

'n Toeligtende memorandum is kort daarna gepubliseer. Binnekort sou die Unie se eerste verdedigingswet die lig sien.

Teruggaande na die wetsontwerp en die memorandum van 1911 kan allereers verklaar word dat die opstellers van die wetsontwerp die mening toegedaan was dat die verdediging van die land die verantwoordelikheid van elke burger is. Daarom is die beginsel van persoonlike diensplig in die wetsontwerp neergelê. Soos uit die voorafgaande oorsig afgelei kan word, was hierdie beginsel reeds van 1865 af deel van ons militêre tradisies. Die beginsel is egter nie ten volle in die wet beliggaam nie.

Dit is ook belangrik om te vermeld dat lede van die Aktiewe Burgermag (A.B.M.) in vredestyd aan 'n vierjarige militêre opleidingsprogram onderwerp sou word, terwyl ander verplig sou word om by skietverenigings aan te sluit (76:17).

Organisatories beskou, het die toekomstige Unie-Verdedigingsmag (U.V.M.) op dié stadium soos volg daaruit gesien :

1. Eerste linie: Aktiewe Burgermag (A.B.M.), 17-25 jaar.

Kusgarnisoenmag (K.G.M.): Vrywilligers vir kusverdediging.

Staande Mag: (die Zuid-Afrikaanse Bereden Schutters).

2. Tweede Linie: Aktiewe Burgermag Reserwe A.

Burgers tot 45 jaar wat vredestydse opleiding van 4 jaar ontvang Aktiewe Burgermag Reserwe B.

Burgers tot 45 jaar wat lede van skietverenigings is.

Kusgarnisoensmag Reserwe.

Oud-lede van die K.G.M. wat hulle vir reserwe-diens beskikbaar stel.

Veldreserwe Z.A.B.S.

Bestaande uit oud-lede van die Z.A.B.S. (vrywilligers) en 'n spesiale groep A-reserviste van die A.B.M. (vrywilligers).

3. Derde Linie: Nasionale reserwe.

Alle burgers van 17 tot 60 jaar wat nie tot die ander linies behoort nie.

4. Organisasies wat nie te velde optree nie:

Kadette, 13-17 jaar. Polisiereserwe Z.A.B.S. Lede van die Breserwe A.B.M., jonger as 30 jaar, (vrywilligers) (73).

Die goewerneur-generaal het op 13 Junie 1912 sy goedkeuring aan Wet nr. 13 van 1912, m.a.w. die Zuid-Afrika Verdedigingswet, verleen en op die wyse is 'n verdedigingsorganisasie daargestel waarop, in groot trekke altans, ons hedendaagse Suid-Afrikaanse Weermag nog berus. 


\subsection{Die Ontwikkelingsgang 1912-1946}

Die Verdedigingswet van 1912 het op 1 Julie 1912 in werking getree. Daar kon nou begin word met die opbou van 'n uniale verdedigingsorganisasie nadat die bestaande militêre gebiedsorganisasies, wat aan die provinsies vasgekoppel was, ontbind is.

Die poste van kommandant-generaal Kaapse Verdedigingsmag, kommandant van Milisie (Natal) en inspekteur van vrywilligers (Transvaal) is afgeskaf en die nuwe hoofkwartier van die Unie-Verdedigingsmag is in Pretoria gevestig.

Dit is soos volg ingedeel:

1. Die sekretariële, 'n siviele tak, insluitende finansies, onder die Ondersekretaris van Verdediging.

2. Die Generale Stafafdeling wat te doen het met militêre organisasie.

3. Die administratiewe afdeling wat te doen het met bevoorrading, ens. $(76: 19-20)$.

Die reorganisasie het ook ander veranderings tot gevolg gehad:

1. Die milisie-, vrywilliger- en kadethoofkwartierstawe is afgeskaf en vervang deur drie bevelvoerings, t.w. dié van die Staande Mag, Aktiewe Burgermag en Kadette onderskeidelik.

2. Die Unie is in $\mathbf{1 4}$ militêre distrikte ingedeel en aanstelling van offisiere by Verdedigingshoofkwartier is gemaak $(76: 20)$.

Aan die begin van 1913 is distriksoffisiere aangestel, terwyl daar reeds op 1 Julie 191251 offisiere van die voormalige militêre organisasies uitgesoek en aangesê is om 'n kursus in die voormalige Presidentswoning, Bloemfontein en later op Tempe te volg om hulle vir die nuwe taak voor te berei. Kursusse vir infanterie-adjudante en stafadjudante het terselfdertyd in Bloemfontein begin.

Behalwe aan die Zuid-Afrikaanse Militaire School is opleidingskursusse ook gereël aan die Zuid-Afrikaanse School voor Geweeroefeninge (Tempe) en die Artillerieschool (Aucklandpark, Johannesburg) (76:21).

'n Nuwe mylpaal in die geskiedenis van die Unie-Verdedigingsmag is op 1 April 1913 bereik toe die Staande Mag onder bevel van brig.-genl. H. T. Lukin, inspekteur-generaal van die Staande Mag, sy verskyning gemaak het.

Die Zuid-Afrikaunse Bereden Schutters Z.A.B.S. of South African Mounted Rifles is op 1 April 1913 uit die permanente en polisiemagte onder die Departement van Verdediging van die provinsies gevorm (20:172).

Hierdie mag van beredenes sou aanvanklik hoofsaaklik polisiewerk in grensgebiede verrig, maar moes ook gereed staan vir enige soort gebeure.

Vanaf 1 Julie 1913 is ou eenheidsbenamings deur nuwes vervang.

Kragtens goewermentskennisgewing Nr. 1675 van 9 Oktober 1913 het sommige eenhede as gevolg van die reorganisasie ontbind, terwyl die nuwe Aktiewe Burgermageenhede oor die nuutgestigte militêre distrikte van die land versprei is (78).

'n Ander gebeurtenis wat vermelding verdien, is die stigting van die Koninklike Marine Vrywilligers-organisasie wat onderskeidelik met 'n afdeling in Kaapstad en Durban onder die Britse opperbevelhebber gestaan het en in Augustus 1914 by die Britse Vloot ingelyf is $(20: 173)$.

In Junie 1912 het genl. Beyers 'n reeks militêre maneuwers in Duitsland en 
elders bygewoon waartydens hy die geleentheid gehad het om gesamentlike Leër/ Lugmag-operasies te aanskou. Met sy terugkeer in die Unie het hy vertoë tot die Unieregering gerig om 'n militêre lugvaart-afdeling, die Zuid-Afrikaunse Vliegenierskorps, van die Verdedigingsmag in die lewe te roep. Die eienaars van 'n vliegskool op Kimberley het onderneem om onder kontrak 'n aantal offisiere van die Verdedigingsmag as vlieëniers vir die voorgenome vlieënierskorps op te lei.

Die gekose Suid-Afrikaners was lte. J. Clisdale, G. S. Creed, E. C. Emmett, Hopkins, Solomon, B. H. Turner, M. van Coller, K. R. van der Spuy, kapt. G. P. Wallace en lt. M. S. Williams*. Na 'n aanvangsopleiding in Kimberley is hierdie manne vir verdere opleiding na Engeland en tot die Royal Flying Corps toegevoeg (69:13).

Gedurende die Randse staking van 1913 kon die Unie-Verdedigingsmag, wat tot nog toe in die opboustadium was, nie bydra om die binnelandse rus en orde aan dit Witwatersrand te herstel nie. In 1914 kon dié organisasie as gevolg van die redelike georganiseerde toestand waaruit dit op die stadium verkeer het, wesenlik daartoe bydra om die rus en vrede in die reeds genoemde onrusgebied te herstel.

Die Unie-Verdedigingsmag het gedurende die Eerste Wêreldoorlog aan die volgende veldtogte deelgeneem: Duits Suidwes-Afrika (1914-1915); Duits OosAfrika (1915-1918); die Wesfront (1915-1918) asook in Egipte en Palestina (19161918).

'n Aantal Henry Farman-vliegtuie het in 1915 uit Europa in Walvisbaai aangekom waar 'n lugmageskader onder kapt. Wallace saamgestel is (68:16). $\mathrm{Na}$ die staking van die vyandelikhede in Duitswes was daar nie meer gebruik vir die Suid-Afrikaanse Vlieënierskorps nie en die personeel is weer na die buiteland waar hulle as No. 26 Suid-Afrikaanse Eskader by die Royal Flying Corps ingelyf is.

Op 3 Augustus 1914 is die R.N.V.R. (S.A. Divisie) gemobiliseer en het met 'n sterkte van 12 offisiere en 267 manskappe in verskeie hoedanighede aan die Suidwes-veldtog deelgeneem. In 1915 is 4 vrywilliger-kontingente na die Royal Navy gesekondeer waar hulle op skepe diens gedoen het tot aan die einde van die Eerste Wêreldoorlog (36:39).

Die Unieregering het die waarde van militêre lugvaart besef en op 1 Februarie 1920 is die Suid-Afrikaanse Lugmag gestig toe lt.-kol. H. A. (later sir Pierre) van Ryneveld aangestel is as Direkteur van Lugdienste. Dit nuut gestigte Lugmag het vir die eerste maal opgetree toe dit die grondmagte ondersteun het gedurende die industriële staking van 1922 aan die Witwatersrand. In Mei dieselfde jaar moes die Lugmag teen die Bondelswart-Hottentotte in Suidwes-Afrika optree. Van 6 tot 22 April 1925 het 'n vlug van drie militêre vliegtuie weereens die orde herstel by geleentheid van die Rehoboth-rebellie (68:17).

Die Zuid-Afrikaanse Militaire School wat voor die oorlog op Tempe gevestig was, is gedurende die oorlog gesluit. In Januarie 1920 is dit na die toenmalige Robertshoogte (vandag Voortrekkerhoogte) verskuif en in Maart 1920 het dit onder leiding van kol. W. E. G. Tanner, C.B., C.M.G., D.S.O., weer met die aanbieding van instruksie- en oefeningskursusse begin $(76: 36)$.

In 1921 is kontingente van die R.N.V.R. (S.A. Divisie) in Port Elizabeth en Oos-Londen gestig en in 1921 is die S.A. Divisie in 'n mynveërseksie en 'n 
algemene diensseksie verdeel (36:39). Die S.A. Vlootdienste (S.A. Naval Services) is in 1922 gestig toe die Britse Admiraliteit twee mynveërs en twee opmetingskepe aan die Unie geskenk het $(20: 174)$.

Die Staande Mag is met ingang van 1 Februarie 1923 op 'n nuwe grondslag geplaas. Die sterkte van die Z.A.B.S. is tot een regiment teruggebring en die volgende nuwe eenhede is gestig:

Die Zuid-Afrikaanse Stafkorps, die Zuid-Afrikaanse Instruktiekorps, die Zuid-Afrikaanse Zeemacht, die Zuid-Afrikaanse Veldartillerie, die Zuid-Afrikaanse Geniekorps, die Zuid-Afrikaanse Vliegdienst, die Zuid-Afrikaanse Dienstkorps, die Zuid-Afrikaanse Geneeskundige Dienst, die Zuid-Afrikaanse Ordonnanskorps, die Zuid-Afrikaanse Veearsenijkundige Korps en die ZuidAfrikaanse Betaalmeesters en Klerkenkorps (76:35).

In 1926 het 'n belangrike gebeurtenis op die gebied van die militêre lugvaart plaasgevind toe die owerhede op Voortrekkerhoogte met die bou van eie vliegtuie begin het. 68 Hartebeesvliegtuie is vervaardig terwyl 27 Wapiti- en 50 Avro Tutorvliegtuie gemonteer is $(68: 17)$.

Die Spesiale Diensbataljon (S.D.B.) is op 1 Mei 1933, gedurende die ekonomiese depressie, met lt.-kol. George Brink as bevelvoerder, op Robertshoogte, tans Voortrekkerhoogte, gestig $(20: 183)$. Die doel van die Spesiale Diensbataljon was o.m. die aan kweek van militêre fiksheid. Gepaardgaande hiermee het dit ook ten doel gehad om die nodige dissipline aan te kweek en dan na 'n jaar se opleiding die jong burgers in die siviele samelewing in geskikte werkkringe te plaas. Afgesien van die verwesenliking van hierdie doelstelling, het 'n groot aantal opgeleide jong manne besluit om van hierdie militêre diens hulle loopbaan te maak.

In 1935 is die Pionierbatalion in Bloemfontein gestig, terwyl met die opleiding van seekadette in dieselfde jaar in die hawestede begin is $(20: 174)$.

In die jare 1937-1938 is buitestasies in Durban, Bloemfontein en Kaapstad opgerig waar leerlingvlieëniers hulle vliegopleiding ontvang het.

\subsection{Die Tweede Wêreldoorlog}

Met die uitbreek van die Tweede Wêreldoorlog, in September 1939, het die gewapende magte van die Unie uit 'n Staande Mag en die Aktiewe Burgermag bestaan, terwyl die Spesiale Diensbataljon bestaan het uit manskappe met kortdienstermyn van minstens een jaar.

As gevolg van die feit dat die Unie-Verdedigingsmag, volgens die toenmalige Verdedigingswet, nie anders as ter verdediging van Suid-Afrkia mag optree nie en die operasionele gebied vaag omlyn was, is die Aktiewe Burgermag op 16 Februarie 1940 gereorganiseer sodat dit nou bestaan het uit vrywilligers wat bereid was om op enige plek in Afrika op te tree $(79: 1)$.

Die vernaamste rede waarom daar 'n vertraging in die aktiewe deelname van die Unie-Verdedigingsmag aan die stryd was, was o.m. gebrek aan uitrusting. Hierdie moeilikheid is geleidelik te bowe gekom en op 20 Mei 1940 is 1 SuidAfrikaanse Infanteriebrigade gemobiliseer as een van die voorlopers van 1 SuidAfrikaanse Divisie onder bevel van genl.-maj. G. E. Brink, C.B., C.B.E., D.S.O. $(79: 1)$.

Hierdie Divisie het 'n belangrike rol in die herowering van Brits-Somaliland en Abbessinië gespeel $(79: 1)$. In Mei 1941 is dit na Egipte oorgeplaas, terwyl die 2 S.A. Divisie, onder bevel van genl.-maj. I. P. de Villiers, na Noord-Afrika vertrek het waar dit op 20 Junie van dieselfde jaar aangekom het. 
Terwyl 1 S.A. Divisie stelling by Mersa Matruh ingeneem het, het 2 S.A. Divisie o.m. die inrigting van verdedigingstellings by El Alamein onderneem.

$\mathrm{Na}$ 'n terugslag by Sidi Rezegh, in November 1941, is suksesse behaal by Bardia, Sollum en Halfaia. Tydens die hergroepering van die Suid-Afrikaanse Divisies het die verowerde Tobruk in Junie 1942 in vyandelike hande geval (76:4-6).

Die offensief van veldmaarskalk Rommel is met die slag van El Alamein in Oktober 1942 gestuit, terwyl Tobruk in November 1942 herower is (79 : 6-9).

In die loop van dieselfde jaar het die Suid-Afrikaanse troepe ook deelneem aan die verowering van Madagaskar (79:9).

In 1943 is 6 Suid-Afrikaanse Pantserdivisie met genl.-maj. W. H. Evered Poole, D.S.O., (later C.B., C.B.E., D.S.O.) as bevelvoerder saamgestel. Die Divisie het in April na Egipte gevaar waar dit intensiewe opleiding by Khataba ontvang het. In April 1944 het die Divisie na Italië gegaan waar dit, saam met ander Suid-Afrikaanse eenhede, aan grootskaalse geallieerde militêre operasies deelgeneem het $(79: 19-12)$.

Dit is belangrik dat iets oor die optrede van die Suid-Afrikaanse Lugmag en die Suid-Afrikaanse Seemag gedurende die Tweede Wêreldoorlog vermeld word.

In September 1939 het die S.A. Lugmag, benewens ook bevel gevoer oor lugafweereenhede en 5 Bataljons Kleurlinginfanterie wat o.m. bewakingsdienste in die Midde-Ooste en Noord-Afrika verrig het.

Die Suid-Afrikaanse Lugmag het op 10 Junie 1940 reeds drie Eskaders in Kenia gehad waar hulle 'n aanval op 11 Junie 1940 op Italiaans Mojale gedoen het en die landmag tydens die verdere verloop van die veldtog in Oos-Afrika en Abessinië kragdadig ondersteun het.

In die Midde-Ooste het die S.A. Lugmag tussen April 1941 en Mei 1943 met 'n maksimum van 11 eskaders oor die 33000 vlugte uitgevoer en 342 vyandelike vliegtuie vernietig. Aan die einde van Mei 1943 het die S.A. Lugmag 2 vleuels en 16 eskaders in die Midde-Ooste en Noord-Afrika gestasioneer gehad.

Die Lugmag het ook op die volgende oorlogsterreine opgetree: Die Sentrale Middellandse See-gebied en Italië, die Oostelike Middellandse See-gebied en die Westelike Middellandse See-gebied (79 : 13-18).

Waar die Suid-Afrikaanse Lugmag tydens die Tweede Wêreldoorlog oor 'n uitgestrekte gebied opgetree het, moet onthou word dat daar aan ons kuste ook 'n belangrike taak uitgevoer moes word. Vanaf die begin van die oorlog het die S.A. Lugmag ons handelsroetes bewaak, terwyl een eskader van 1943 tot middel 1945 in Wes-Afrika gestasioneer was (76:67).

Belangrik was ook die troepe- en voorraadvervoerdienste tussen die Unie en die verskillende gevegsfronte wat gedurende die oorlog uitgevoer is, terwyl ook repatriasievlugte onderneem is.

Die S.A. Verdedigingsmag ter See is op 15 Januarie 1940 opgerig. Op 1 Augustus 1942 is die Verdedigingsmag ter See en die R.N.V.R. (S.A. Divisie) verenig onder die naam van die Suid-Afrikaanse Seemag. Alle offisiere en manskappe van laasgenoemde liggaam wat by die Britse Vloot diens gedoen het, is outomaties na die S.A. Seemag oorgeplaas. 
Die Suid-Afrikaunse Seemag, die jongste van Suid-Afrika se Weermagsdelc het in Mei 1940 met mynveërwerk begin. Die mynopruimingsflotielje het ook saam met eenhede van die Britse Vloot operasies uitgevoer, waarvan die belangrikste die onderskepping en gevangeneming van 'n Vichy-konvooi in November 1941 was. Hierdie optrede het in Suid-Afrikaanse waters plaasgevind.

Die bedrywighede van die Seemag was nie tot Suid-Afrikaanse waters beperk nie. Op versoek van die Britse Admiraliteit is vier duikbootjagvaartuie na die Middellandse See gestuur waar hulle op 11 Januarie 1941 in Alexandrië aangekom het.

$\mathrm{Na}$ verloop van tyd het vier S.A. duikbootjagvaartuie, agt mynveërs en een bergingskip in die Middellandse See diens gedoen.

Die grootste ontwikkeling in die geskiedenis van ons seemag het heeltemal teen die einde van die oorlog plaasgevind toe drie fregatte aangeskaf is. Dit was die eerste vaartuie wat as oorlogskepe ontwerp is, wat onder die SuidAfrikaanse vlag gevaar het. (78:18-19).

Op 8 Mei 1945 het die oorlog in Europa tot die verlede behoort. Bykans 24000 offisiere en 162000 manskappe het aan krygsverrigtings op die verskillende fronte deelgeneem.

$\mathrm{Na}$ die sluiting van die vrede in 1945 het die Unie-Verdedigingsmag die groot taak gehad om demobilisasiemaatreëls deur te voer. 


\section{LIGGAAMLIKE OPLEIDING IN DIE VERDEDIGINGSORGANISASIE VAN BRITTANJE}

\subsection{Inleiding}

In ons eie land het 'n eiesoortige militêre stelsel en tradisies ontwikkel wat by die land se militêre behoeftes en omstandighede aangepas het en as gevolg van verskeie faktore afgewyk het van die ontwikkelingsgang wat die Europese militêre stelsels in die loop van die eeue deurgemaak het. Hierdie twee stelsels ontmoet mekaar in Suid-Afrika in die 19de eeu as gevolg van die Britse okkupasie et. verowering van ons ou hartland, die Kaap, Natal en die latere uitbreiding van die Britse gesag in ons land. Hiermee het gepaard gegaan 'n versterkte Britse beinvloeding deur hoër gesag, op suiwer militêre sowel as op militêre liggaamlike opleidingsgebied, wat, ook na Uniewording, nog geruime tyd voortgeduur het en tot vandag toe nog merkbaar is.

Om geen aandag aan die ontwikkelingsgang van liggaamlike opleiding in die Britse militêre organisasie te skenk nie, sou beteken dat ons 'n onvolledige weergawe sou gee van wat op daardie gebied gebeur het.

Liggaamlike opleiding in die Britse militêre organisasie kan duidelik in 3 rigtings, nl. in die Britse leër, die lugmag en die vloot, nagegaan word. In hierdie hoofstuk sal daar gepoog word om die geskiedenis van liggaamlike opleiding in bovermelde vertakkinge van die Britse Weermag aan te toon.

5.2 Algemene Oorsig

Sedert die vroegste tye het die Britse volk 'n voorliefde vir sport en spele geopenbaar; trouens die meeste van die spele wat in Suid-Afrika beoefen word, is van hulle afkomstig. As gevolg van die taamlik geïsoleerde ligging van Brittanje, sy militêre slaankrag en goed georganiseerde vloot, het daar weinig vrees vir 'n gewapende inval in Brittanje bestaan. Dit het baie daartoe bygedra dat die Britte nie die noodsaaklikheid ingesien het om die militaristiese tipe formele oefeninge en aktiwiteite, wat so kenmerkend van die toenmalige kontinentale Europese stelsels was, te beoefen nie. Die hoofdoel was om sport en rekreatiewe vaardighede as vorms van vryetydsbesteding te ontwikkel.

Militêre opleiding is uitgesonder as 'n aktiwiteit op sigself en nie as die basis van 'n liggaamsopvoedingsprogram nie. Die gemiddelde Britse burger het 'n afkeer aan formele oefeninge en 'n voorliefde vir spele gehad. Dit is dus natuurlik dat die Brit sy spele met hom saamgeneem het, ongeag in watter deel van die wêreld by hom bevind. 'n Voorbeeld hiervan vind ons in 1860 aan die Kaapse Oosgrens waar 'n Britse militêre eenheid, die North Lincolnshire Regimeni, gestasioneer was. Offisiere en manskappe van hierdie Britse eenheid het in die twee jaar van hul verblyf aan die Keiskama Hoek aan krieketwedstryde en verskeie spele met 'n atletiek-inslag deelgeneem. So is 'n atletiekbyeenkoms op die Britse Koningin se verjaarsdag op 24 Mei 1860 by Fort England, Grahamstad, gehou waaraan onderoffisiere en manskappe deelgeneem het. Die program vir hierdic byeenkoms het 100 tree naelloop, 200 tree hekkies, 440 tree (Lower Albany Stakes, Lilliputian handicap), oor 100 tree, verspring, hoogspring, sakreisies, kruiwastoot, hamergooi (throwing the sledge hammer), driespring, gewigstoot (putting the stone), tossing the caber en single stick ingestuit $(53: 6)$. Ander soortgelyke byeenkomste is ook op Kersfees 1860, Kersfees 1861 by Fort England en op 24 Mei 1862 by Fort Beaufort gehou $(53: 208)$. 
Dit was in die 19de eeu dat die teorië en prestasies ten opsigte van gimnastiek hul invloed vanaf die kontinent na Brittanje uitgebrei het.

P. H. Clias, 'n Switserse Leëroffisier, het in 1822 na Londen gegaan en Guts Muths se metodes in die Britse leër en vloot ingevoer. Sweedse gimnastiek is in 1840 vir die eerste keer deur lt. Ehrenhoff in Brittanje ingevoer toe hy 'n privaatgimnasium te Londen geopen het. In 1850 het Carl Georgii gevolg wat hom ook op die privaat-onderrig van gimnastiek in Londen togespits het. Beide, Ehrenhoff en Georgii, het hul opleidng aan die Koninklike Sentrale Instituut in Stockholm ontvang $(4: 17-18$.

Archibald Maclaren het teen ongeveer die middel van die 19de eeu begin om, deur middel van onderrig in en geskrifte oor liggaamlike opvoeding, die ontwikkeling van genoemde vakgebied in Brittanje te beïnvloed. Hy het 'n privaatgimnasium in Oxford in 1858 geopen waar hy sy omvattende stelsel van progressiewe gimnastiek ontwikkel het $(4: 8)$.

Dit is dus duidelik dat die invloed van die Duitse gimnastiek en die Sweedse stelsel bygedra het om die sport en spele soos dit in Brittanje beoefen was, te beïnvloed en te wysig.

\subsection{Die Ontwikkeling van Liggaamlike Opleiding in die Britse Leër}

\subsubsection{Die Begin}

Die inskakeling van behoorlik georganiseerde liggaamlike opleiding in die Britse leër kan aan die Krimoorlog (1854-1856) en die Indiese opstand (1857) toegeskryf word. Aan die einde van laasgenoemde gebeurtenis het die Britse militêre owerhede besef dat alles nie pluis met die fisieke fiksheid van die Britse leër was nie $(31: 568)$.

Om 'n vorm van fiksheidopleiding vir die Britse leër daar te stel, is maj. Hammersley en 12 onderoffisiere (bekend as ,die Twaalf Apostels") in 1860 uit verskeie eenhede van die Britse leër gekies om aan Archibald Maclaren se gimnasium in Oxford as instrukteurs in liggaamlike opleiding opgelei te word $(43: 94)$.

Die leerplan wat Maclaren in gedagte gehad het vir die opleiding van hierdie groepie militêre instrukteurs het eenvoudige bewegings en posisies, oefeninge met hand- en stanggewigte ingesluit. Dit het veral uit oefeninge met handapparate, klimtoue, pale, maste, rekstokke, brûe, springkaste, sweefstokke, ringe en lere bestaan $(7: 94)$.

Die kursus wat maj. Hammersley en sy onderoffisiere aan Maclaren se gimnasium gevolg het, is betekenisvol omdat dit die eerste keer sedert die ontstaan van die Britse leër (ongeveer twee eeue gelede) is dat opleiding spesifiek met betrekking tot liggaamlike fiksheid amptelik erken is (43:94).

Aan die einde van die opleidingstydperk van ses maande het maj. Hammersley en sy ,twaalf apostels" 'n skool in Wellington, Aldershot, geopen waar toekomstige militêre instrukteurs in liggaamlike opleiding opgelei sou word (43: 94).

Die stelsel wat in 1861, d.w.s. na afloop van maj. Hammersley se kursus, in die Britse leër toegepas is, was gebaseer op die stelsel van opleiding wat deur Maclaren toegepas is. Die leerplanne wat aan die nuut gestigte skool te Aldershot ingevoer is, het grotendeels bestaan uit oefeninge op die rekstok, die brug of die sweefstok, hand- en stanggewigte. Die resultaat hiervan was dat die spiere van die arms, skouers en bors geweldig ontwikkel het in vergelyking met die beenspiere $(43: 95)$. 


\subsubsection{Verdere Ontwikkeling}

Die eerste regulasies waarvolgens liggaamlike opleiding in die Britse weermag uitgevoer moes word, is in 1865 neergelê $(43: 95)$. Daarvolgens het liggaamlike opleiding gedurende die eerste twee maande van 'n rekruut se opleidingstydperk, voorrang bo alle ander vorme van militêre opleiding geniet, terwyl die opgeleide soldaat jaarliks 'n kursus van drie maande in liggaamlike opleiding moes bywoon. Die opgeleide soldate wat spesiale opleiding aan die dag gelê het, is gekies om 'n verdere kursus by die skool te Aldershot by te woon. Sodoende het die eerste regiment assistent-instrukteurs in liggaamlike opleiding hul verskyning in die Britse leër gemaak. Instrukteurs wat as geskik beskou is, is uit hierdie assistent-instrukteurs gekies om op die personeel van die skool te Aldershot te dien $(31: 586)$.

Hierdie vooruitgang het nie beteken dat liggaamlike opleiding in die Britse leër op daardie tydstip op 'n klinkklare grondslag geplaas is nie. Gedurende die vroeë jare van dit huidige eeu het die Britte oor die algemeen op die gebied van liggaamlike opleiding beide in teorie, praktyk en ook wat leiers betref, baie van Deense en Sweedse materiaal gebruik gemaak. Vooraanstaande Deense en Sweedse gimnastiekonderwysers, waaronder A. Broman, C. P. Mauritzi, H. P. Lankild en H. G. Junker, is deur verskeie Britse inrigtings, sowel as die Britse leër en vloot, in diens geneem. So het die leëroutoriteite teen 1906 die stelsel wat deur lt. H. P. Lankild van die Deense leër gepropageer is, ingevoer (31:586).

In 1908 het die amptelike Manual of Physical Training vir gebruik in die Britse leër die lig gesien.

\subsubsection{Liggaamlike Opleiding Gedurende die Eerste Wêreldoorlog}

Met die uitbreek van die Eerste Wêreldoorlog in 1914 is die handboek Special Tables Physical Training 1914 in Londen gepubliseer. Die lesprogramme wat in hierdie pamflet vervat is, is saamgestel om as 'n gids of handleiding vir superintendente en instrukteurs te dien wat met omstandighede te make gehad het waarvoor daar nie in die amptelike handleiding voorsiening gemaak is nie.

Hierdie lesprogramme of tabelle soos dit in daardie tyd bekend gestaan het, was daarop gemik om maksimum aktiwiteit aan groot getalle swak geklede rekrute sonder die hulp van apparate te verskaf.

Elke lesprogram is in twee verdeel. Die eerste deel het oefeninge bevat wat slegs deur gekwalifiseerde instrukteurs in liggaamlike opleiding doseer kon word, terwyl die tweede deel deur enige intilligente onderoffisier na 'n kort verduideliking aangebied kon word.

Beide dele moes binne die voorgeskrewe tyd van een uur, wat vir liggaamlike opleiding afgesonder was, voltooi word. Elke rekruut moes op 6 dae per week aan liggaamlike opleiding deelneem.

bou.

Elke lesprogram is uit inleidende, algemene, en finale oefeninge opge-

Maj. R. B. Campbell het die eerste oorsese skole vir liggaamlike en bajonetopleiding in 1916 te Flixecourt en later te St. Pol, Frankryk, gestig (31:586).

In dieselfde jaar het die Britse leëroutoriteite weereens 'n reeks spesiale lesprogramme daargestel met dieselfde doel as die van 1914, nl. om maksimum aktiwiteit aan groot getalle rekrute sonder die hulp van apparaat te verskaf. 
Die indeling van die lesprogram was soos volg:

Inleidende oefeninge - eenvoudige oefeninge wat só gerangskik is om bloedsirkulasie deur die hele liggaam te bevorder en om die liggaam vir die meer stremmende oefeninge voor te berei.

Algemene oefeninge - só gerangskik om elke deel van die liggaam simmetries te ontwikkel en te versterk.

Finale oefeninge - daarop gemik om die werking van die hart en longe na hul normale ritme te laat terugkeer.

'n Nuwe handleiding, getitel Physical Training, is in 1918 deur die Britse Generale Staf in Londen uitgegee. Die lesopbou en -patroon het dieselfde vorm aangeneem as in die spesiale lesprogramme van 1914 en 1916 aangedui was. Die oefeninge is egter meer gespesialiseer en in die volgende kategorieë verdeel: Been, nek, arm, romp, balanseer, marsjeer, hardloop en spring.

Die samestelling van hierdie handleiding is interessant in dié opsig dat elke voorgeskrewe oefening deur middel van sketse geïllustreer is. Hierdie metode het dié voordeel dat elke instrukteur presies kan sien hoedat die verskillende oefeninge uitgevoer moet word. Verder dra dit ook daartoe by dat die aanbieding van liggaamlike opleidingsklasse deur verskillende instrukteurs op 'n eenvormige grondslag kan geskied.

\subsubsection{Die Periode 1920-1938}

Die ontwikkeling op die gebied van liggaamlike opleiding in die Britse leër tussen die Eerste- en Tweede Wêreldoorlog was grotendeels beperk tot die verbetering van individuele oefeninge wat daarop gemik was om 'n gebalanseerde fisieke opbou van rekrute te bewerkstellig en om 'n hoë peil van liggaamlike fiksheid by die opgeleide soldaat te handhaaf.

In daardie tydperk is navorsing in ander lande m.b.t. liggaamlike opleidingsmetodes verrig wat in militêre kringe toegepas kan word. Weereens het nuwe gedagtes van die Skandinawiese lande gekom. Dit was veral maj. T. H. WandTetley, 'n Britse liggaamlike opleidingsoffisier, wat noue skakeling met die Deense Skool te Ollerup bewerkstellig het. Die stelsel van Niels Bukh is met die Sweedse stelsel gekombineer nadat eksperimente in 1927 by Aldershot uitgevoer is (31: 589).

'n Nuwe handleiding, die Manual of Physical Training, het in 1931 die lig in die Britse leër gesien.

Algemeen gesproke was die doel en omvang van liggaamlike opleiding in die Britse leër om die man in staat te stel om homself liggaamlik en geestelik as 'n soldaat te bekwaam.

In die besonder kan die doel van liggaamlike opleiding soos volg saamgevat word: Om die karakter te ontwikkel; om wakkerheid van gees aan te kweek; om liggaamlike fiksheid in harmonieuse verhouding te skep.

Met hierdie doelstelling voor oë het die opstellers van voormelde handleiding die oefeninge in die volgende kategorieë gegroepeer: Marsjeer en hardloop, been, nek, arm, koördinasie, hys, lateraal, balanseer, buik, bors, behendigheid, spring (stand en met apparaat), steunspronge, behendigheid, finaal en korrektief.

Saamgestelde lesings vir die gebruik van instrukteurs in liggaamlike opleiding is ook in hierdie handleiding ingesluit. Die vernaamste onderwerpe wat hierin vervat is, sluit in: Hindernisopleiding, afstand hardloop, rekreatiewe opleiding, elementêre anatomie en fisiologie. 
Benewens die formele liggaamlike opleiding het die opstellers van genoemde handleiding die waarde van sport en spele as aanvullend tot liggaamlike opleiding beklemtoon. Sport en spele kan, volgens die opstellers, liggaamlike opleiding nie vervang nie omdat:

Dit nie dieselfde korrektiewe uitwerking het nie; dieselfde gereelde sistematiese en progressiewe resultate nie bereik kan word nie; en dit dikwels nie moontlik is om voldoende speelruimtes, -velde en -sale vir almal te bekom nie.

Die grootste nadeel verbonde aan die deelname aan sport en spele in groepsverband is die feit dat swakker deelnemers (die man wat die meeste oefening nodig het) dikwels deur die beter spel van sy kollegas ontmoedig word met dié gevolg dat hy 'n toeskouer word.

Aktiwiteite wat in die Britse militêre handleiding van 1931 as rekreatiewe opleidingsaktiwiteite geklassifiseer word, is boks, stoei, swem, bajonetskerm, skerm en aangeebal.

\subsubsection{Liggaamlike Opleiding gedurende die Tweede Wêreldoorlog}

Die tydperk wat gewoonlik bekend staan as die voorspel tot die Tweede Wêreldoorlog het o.m. tot gevolg gehad dat die hele stelsel van liggaamlike opleiding in die Britse leër noukeurig ondersoek is. Dit het tot gevolg gehad dat liggaamlike opleidingsprogramme vir rekrute hersien en nuwe lesprogramme vir opgeleide soldate opgestel is.

In hierdie tydperk het die lae fisieke fiksheidspeil van vrywilligers wat by die Britse leër aangesluit het ook kommer in Britse militêre kringe veroorsaak. 'n Spesiaal saamgestelde kursus vir remediële en kondisioneringsopleiding is van stapel gestuur om die lae fisieke fiksheidpeil van hierdie vrywilligers te verbeter. Dit het tot gevolg gehad dae die eerste Recruits Physical Development Depot kort voor die uitbreek van die Tweede Wêreldoorlog te Canterbury geopen is (31:589).

Die uitbreek van die Tweede Wêreldoorlog (1939) het in die Britse leër die probleem laat ontstaan dat die aantal beskikbare liggaamlike opleidingsinstrukteurs nie opgewasse was om die groot getal rekrute wat hulle vir militêre diensplig aangemeld het, te hanteer nie. Om hierdie probleem te oorbrug is assistentregimentsinstrukteurs, onderwysers, vooraanstaande Britse atlete, sportafrigters en ander Britte wat oor kennis van liggaamlike opleiding beskik het as instrukteurs opgelei $(31: 589)$.

Op 16 September 1940 is al die liggaamlike opleidingsinstrukteurs in een korps saamgevoeg en het die Army Physical Training Corps ontstaan.

Die probleme waarmee die Britse militêre owerhede gedurende die eerste jare van die Tweede Wêreldoorlog te kampe gehad het, het o.a. die fiksmaking van groot aantalle rekrute binne 'n kort tydsbestek ingesluit.

Die oplossing vir hierdie probleem het die Britte in 1941 gevind in die samestelling van ses basiese lesprogramme met die doel om krag en uithoudingsvermoë van die rekrute wat by al die vertakkinge van die Britse leër ingedeel is, te verbeter.

Elke lesprogram is saamgestel om spierkrag, kardiovaskulêre uithouvermoë en beweeglikheid van gewrigte te ontwikkel. Voorts het dit ook korrekte tegnieke van stap, hardloop, behendigheid en houding ingesluit.

Die lesprogramme is só saamgestel dat instrukteurs toegelaat is om oefeninge te kan wysig om by die standaard en spesifieke behoeftes van individue aan te pas. 
Op 20 Mei 1942 het verdere verwikkelinge op die gebied van liggaamlike opleiding in die Britse leër plaasgevind toe die lesprogramme van 1941 deur 'n stelsel van doelgerigte en basiese liggaamlike opleiding vervang is.

Die leerplan wat vir hierdie doelgerigte liggaamlike opleiding, wat deur opgeleide soldate gevolg is, neergelê is, was só saamgestel dat dit aangepas kon word by die verskillende toestande waaronder liggaamlike opleiding by veldmagte aangebied moes word. Die leerstof was van so 'n aard dat die aan die instrukteur 'n wye keuse gebied het wanneer hy 'n lesprogram vir 'n betrokke eenheid moes saamstel.

Die raamwerk, waarvolgens lesprogramme opgebou moes word, het die volgende indeling, tydsduur en aktiwiteite behels:

Deel Een - opwarmingsoefeninge -7 minute.

Deel Twee - aktiwiteite - 10-50 minute.

Die aktiwiteite het uithouvermoë-, krag-, stoot- en trek-, hys-, optel en dra- ,medisynebal-, stomp-, spoed- en behendigheidsoefeninge en hindernisopleiding ingesluit.

Deel Drie - finale oefeninge -3 minute.

Die hele lesprogram het een uur in beslag geneem.

Benewens die lesprogramme is 'n reeks van nege bekwaamheidstoetse neergelê wat die opgeleide Britse soldaat moes uitvoer. Dit het uit die volgende bestaan:

1 -Landloop - 2 myl in 16 minute.

2-Hardloop - 200 tree gevolg deur 'n skietoefening met diensgewere waarin drie uit vyf skote treffers moes wees. Die tydsbestek vir die oefening was een minuut en 15 sekondes.

3-Geforseerde marsjeer - tien myl in twee uur gevolg deur 'n skietoefening.

4-Die dra van 'n man (van ongeveer dieselfde gewig as die toetsling) oor 'n afstand van 200 tree in twee minute.

5-100 tree alarmreisies in 5 minute en 30 sekondes. (Die toetsling begin die toets in sy liggaamlike opleidingsuitrusting. Sy gevegsmondering word 20 tree vanaf die wegspringstreep geplaas. Sodra hy die bevel kry, hardloop hy tot by sy gevegsmondering, trek dit aan en hardloop die oorblywende 80 tree na die eindpunt).

6-Spring oor 'n agt voet ses duim wye sloot en kom op albei voete neer.

7 -Klouter oor 'n ses voet hoë muur.

8-Klim teen 'n 12 voet hoë vertikale tou op, seil oor 'n 20 voet horisontaal gespande tou en klim met 'n ander tou af tot op die grond.

9--Swem 20 tree (stewels word om geweer of nek gehang). Swem 60 tree in varswater of 100 tree in soutwater. (Hierdie toets word met gevegsmondering aan, maar sonder stewels uitgevoer).

Die gedeelte van die handleiding wat vir basiese liggaamlike opleiding van rekrute voorsiening gemaak het, het vier lesprogramme ingesluit. Die doel met hierdie lesprogramme was om beweeglikheid van gewrigte, krag, kardiovaskulêre uithouvermoë en behendigheid van rekrute te bevorder. Geen gevestigde apparaat, met die uitsondering van klimtoue, is vir die uitvoering van hierdie lesprogramme nodig nie.

Die lesprogramme is in vier dele verdeel:

Deel Een - opwarmingsoefeninge - 6 minute. 
Deel Twee - krag en uithouvermoë 16 minute. Hierdie deel van die lesprogram het oefeninge bevat wat die verbetering van houding, versterking van die spiere van die romp, arms, bene en die bevordering van uithouvermoë ten doel het. Benewens rompoefeninge is ook voorsiening vir versterkende en kompeterende spanspele, trek-, stoot-, optel- en dra-, marsjeer- en handloopoefeninge gemaak.

Deel Drie - behendigheid - 16 minute. Klim-, spring-, behendigheidsen neerkomoefeninge vir valskermspringers is in hierdie deel ingesluit om vaardigheid en moed te bevorder.

Deel Vier - finale oefeninge -2 minute.

Die lesprogram is afgesluit met finale oefeninge waartydens die houding van rekrute gekorrigeer is.

In die handleiding van 1942 is ook basiese bekwaamheidstoetse vir die rekrute voorgeskryf. Dit het uit die volgende bestaan :

1

100

Punte

10

8

6

4

2

\section{2}

Hoog-

spring
3

Verspring
4

Hys $9 \mathrm{p}$. medisynebal

34 vt.

$30 \mathrm{vt}$.

$25 \mathrm{vt}$.

22 vt.

$18 \mathrm{vt}$.
5

Een myl

$5.30 \mathrm{~min}$.

$6.00 \mathrm{~min}$.

$6.20 \mathrm{~min}$.

$6.40 \mathrm{~min}$.

$7.00 \mathrm{~min}$. die skaal:

Rekrute is geklassifiseer in spesiaal, eerste en standaardklasse volgens

Spesiaal - 42 punte of $84 \%$;

Eerste klas - 34 punte of $68 \%$;

Standaard -24 punte of $48 \%$.

Vir die hysoefening word 'n opgestopte sokker- of medisynebal met 'n gewig van 9 pond gebruik. Die toetsling staan wydsbeen en hou die bal met albei hande voor sy lyf of bokant sy kop. Om die gooi te begin, buig die toetsling vorentoe en swaai die bal tussen sy bene, wat terselfdertyd gebuig word, deur. Die bene word nou gestrek en die bal vorentoe geswaai en laat los. (Slegs een swaai word toegelaat.)

In 1944 het die Britse Departement van Verdediging nogeens 'n pamflet, Basic and Battle Physical Training, uitgegee. Hierin is voorsiening vir die liggaamlike opleiding van rekrute en opgeleide soldate onder die ouderdom van 35 jaar sowel as vir dié bo 35 jaar gemaak. Dit het bestaan uit ses basiese lesprogramme en is gevolg deur personeel wat by hulpeenhede* van die Britse leër ingedeel is en nie nodig gehad het om aan die fiksheidsvereistes van die vegtende soldaat te voldoen nie.

Die lesprogramme is saamgestel met die doel om beweeglikheid, krag, uithoudingsvermoë, behendigheid en spoed te bevorder. 
Die lesplan was soos volg opgebou:

Deel Een - opwarmingsoefeninge - 5 minute.

Deel Twee - kragoefeninge - 12 minute.

Deel Drie - uithouvermoë-oefeninge - 6 minute.

Deel Vier - behendigheids- en spoedoefeninge -15 minute.

Deel Vyf - houdingsoefeninge -2 minute.

Die lesprogramme vir die ouderdomsgroep bo 35 jaar is op dieselfde wyse as hierbo ingedeel. Die oefeninge was minder straf en die verswaring van oefeninge het nie so vinnig plaasgevind nie.

Die opstellers van bogenoemde handleiding het ook 'n reeks basiese liggaamlike geskiktheidstoetse saamgestel wat daarop gemik was om aan rekrute 'n aanduiding van hulle liggaamlike geskiktheid op verskillende stadia van hulle opleiding te gee. Verder het dit ook gedien as 'n maatstaf om die geskiktheid van die eenheid as 'n geheel te bepaal.

Dié toatse is onder behendigheid, krag en uithouvermoë geklassifiseer.

Benewens die basiese liggaamlike geskiktheidstoetse is ook voorsiening in die pamflet van 1944 vir basiese prestasietoetse gemaak. Die toetse is onder behendigheid, krag, uithouvermoë en swem ingedeel. Geen punte is vir hierdie toetse toegeken nie en die uitslag is as slaag of druip aangeteken. Die hoofdoel met hierdie toetse was slegs om te bepaal of ' $n$ individu in staat is om aan 'n neergelegde standaard te voldoen al dan nie.

Hierdie stelsel van liggaamlike opleiding is in die Britse leër tot aan die einde van die Tweede Wêreldoorlog toegepas.

In die volgende paragrave sal enkele opmerkings oor die fisieke fiksheidsopleiding ten opsigte van lede van die Britse lugmag en vloot gemaak word.

\subsection{Fiksheid in die Britse Lugmag}

Die opleiding van Britse Lugmagpersoneel kan in twee groepe verdeel word, naamlik dié van bemannings en grondpersoneel.

Gedurende die aanvangstadium van die bemanning se opleiding volg alle toekomstige vlieëniers 'n kursus in liggaamlike opleiding. Hierdie stadium moet gesien word as 'n voorbereidingsfase vir die intensiewe vliegopleiding wat hierna volg.

Dit Britse lugmagaoutoriteite het liggaamlike opleiding as 'n belangrike faktor in die opleidingsprogram gedurende die eerste drie maande van 'n vlieënier se opleiding beskou. 'n Kenmerk van die fiksheidsprogramme was dan ook die geleidelike verswaring van elementêre oefeninge na meer strawwe aktiwiteite.

Winterbottom $(72: 14)$ vermeld die volgende doelstellings ten opsigte van liggaamlike opleiding vir Britse militêre vlieëniers:

1-Algemene liggaamlike opleiding as 'n kondisioneringsmaatreël met die klem op korrektiewe werk en oefeninge vir die versterking van die gewrigte en buikspiere.

2-Die ontwikkeling van neuro-muskulêre koördinasie en vinnige reaksievermoë deur middel van asimmetriese oefeninge en vinnige balspele.

3-Die klem op die rekreatiewe aspek om die grondslag vir self-uitdrukking in sport en spele gedurende latere stadia van die vlieënier se opleiding te vorm.

4-Die opleiding van vlieëniers in die swemkuns. (Vlieëniers moet 'n minimum afstand van 100 tree kan swem). 
$\mathrm{Na}$ voltooiing van die inleidende fase van hul opleiding word die liggaamlike opleiding van vlieëniers by hul diensvereistes aangepas.

Die liggaamlike opleidingsprogram wat gedurende hierdie stadium van die vlieënier se opleiding gevolg is, het verskeie aktiwiteite ingesluit:

1-Oefeninge vir algemene beweeglikheid en koördinasie wat die stimulering van vinnige reaksievermoë, tydsreëlinge en beheer van beweging ten doel het.

2-Ligte padwerk of landloop, afgewissel deur aktiwiteite om uithouvermoë en kardio-respiratoriese doeltreffendheid te ontwikkel.

3-Hindernisbaan-opleiding.

4-Ligte paal- en stokoefeninge vir die versterking van swak rompspiere.

5-Touklim-oefeninge vir die versterking van gewrigte en armspiere.

6-Gevegs- en stoei-aktiwiteite met die doel om selfverdediging te verhoog.

7 -Ontsnappingsoefeninge oor oop terrein en gedurende die nag.

8 - Spronge en behendigheid om vinnige beweging en ratsheid te bevorder.

9 -Vaardighede wat afstandskatting e.d.m. ten doel het.

10-Aflosse en spele om deursettingsvermoë te bevorder.

11 -Sintetiese valskermopleiding om die vermoë om vinnig en suiwer uit 'n vliegtuig te spring, beheer tydens daling en veilige landing te verseker.

12-Liggaamsoefeninge onder swak verligte toestande.

13-Swem en die hantering van nat rubberbootjies.

14-Georganiseerde spele vir ontspanningsdoeleindes en om belangstelling by lede aan te wakker $(72: 18)$.

Die finale fase van 'n vlieënier se opleiding sluit werklike operasionele optrede in. Dit is veral gedurende hierdie fase dat daar 'n behoefte aan ontspanning bestaan. Deelname aan sport en spele word aangewend as 'n hulpmiddel om bekommernisse te vergeet en om spanning, waarin die vlieënier verkeer, te verlig $(72: 18)$.

Liggaamlike opleiding van grondpersoneel in die Britse lugmag het ook nie agterweë gebly nie.

Die skema wat vir die fiksmaking van die grondpersoneel voorgeskryf is, het in baie opsigte van dié wat deur die vlieëniers gevolg is, verskil.

Gedurende die basiese opleiding van rekrute en die daaropvolgende kursusse wat hulle moes volg, is liggaamlike opleidingsklasse volgens die rekrute se ambag, ouderdom en die mediese kategorie verdeel. Om hierdie verdeling moontlik te maak, is die volgende klassifikasie gebruik:

1-Klas A: Alle grondpersoneel onder die ouderdom van 32 jaar met 'n mediese kategorie 1 en wat 'n gesigskerpte van graad 2(a) gehad het.

2-Klas B: Alle personeel bo die ouderdom van 32 jaar, maar onder 40 jaar, wat binne die mediese kategorie 1 val en 'n gesigskerpte van graad 2(a).

3-Klas C: Alle personeel wat in mediese kategorie 2 geplaas is (behalwe 2(a) gesigskerpte).

4-Klas D: Alle personeel bo die ouderdom van 32 jaar, maar onder 40 jaar, wat in mediese kategorie 2 val (behalwe graad 2(a) gesigskerpte).

5 - Spesiale klasse: Vir lede bo 40 jaar en rehabilitasiegroepe. 
By die kies van die soort oefeninge vir 'n bepaalde periode van die dag het die Britse liggaamlike opleidingsinstrukteurs die soort werk wat die grondpersoneel gedurende die dag doen in aanmerking geneem. Die leerlingpasser het bv. op die dae wanneer hy lesings bygewoon het, andier soort oefeninge gedoen as op die dae wanneer hy praktiese werk in die werkswirikels verrig het $(72: 23)$. Hierdie maatreëls kan gesien word as 'n stap om die uitwerking van die beroep op die menslike liggaam teen te werk.

Kantoorwerkers het oefeninge gedoen waar die klem op algemene beweeglikheid geval het. Hierbenewens is daardie spiergroepe wat gewoonlik deur die lang ure in 'n sittende posisie geaffekteer word, versterk.

Liggaamlike opleiding van personeel in Britse Lugmagskole en- opleidingsentrums is gekenmerk deur 'n mengsel van toegepaste liggaamlike opleiding wat onderwerpe soos handgemeengevegte en hindernisbaanopleiding ingesluit het.

In operasionele en onderhoudseenhede is 'n ,oefen-terwyl-u-werk-" skema toegepas. Dit het daarin bestaan dat liggaamlike opleidingsinstrukteurs by die verskillende werkswinkels rondgegaan het en oefeninge wat van 15 tot 20 minute duur aan die werkers gegee het. Hierdie oefeninge is in die vorm van ligte ontspanningsaktiwiteite aangebied. Die toepassing van hierdie skema het egter vele probleme opgelewer. Die getal grondpersoneel waarvoor die instrukteurs voorsiening moes maak, die tyd waarop oefeninge aangebied moes word en die verspreiding van die seksies binne die werkswinkels, is slegs 'n paar probleme wat oorbrug moes word (72-: 23).

Uit hierdie gegewens is dit duidelik dat die Britse militêre owerhede besef het dat fiksheid 'n noodsaaklike faktor in die opleiding van vlieëniers en grondpersoneel is.

\subsection{Liggaumlike Opleiding in die Britse Vloot}

Voordat stoom bekend was, het die seeman sy take in die opelug aan boord van seilskepe uitgevoer. Sy daaglikse aktiwiteit het klim, trek en hys ingesluit. Die gevolg hiervan was dat seemanne 'n geharde liggaam ontwikkel en voldoende oefening gekry het.

Die uitvinding van stoom en meganiese instrumente het meegebring dat seemanstake al meer en meer onderdak en in beknopte ruimte uitgevoer moes word. As gevolg hiervan het die seeman onvoldoende vars lug en te min oefening gekry. Hoewel die meganiese doeltreffendheid, spoed en die groter seewaardigheid van die skepe dit moontlik gemaak het om langer afstande in korter tye af te lê, het dit ook tot nadelige gevolge vir die bemanning gelei. Daar was geen ontspanningsgeriewe aan boord nie en die meeste manne het, somtyds met ongunstige gevolge, die naaste kantien opgesoek sodra hulle aan wal gestap het.

Dit het daartoe gelei dat die Britse vlootowerhede besluit het om 'n stelsel van liggaamlike opleiding vir alle seuns en nuwelinge in te stel. Die doel hiermee was om hulle fiks te mak voordat hulle seediens 'n aanvang neem (35: 73).

Liggaamsoefeninge moes ook 'n deel van die seeman se daaglikse roetine vorm, terwyl deelname aan ontspanningsaktiwiteite angemoedig is wanneer die matrose en seesoldate aan wal verkeer het $(35: 73)$.

In 1888 het die Britse vlootoutoriteite vrywilligers gevra om opgelei te word as instrukteurs in gimnastiek. Vir hierdie doel is ' $n$ opleidingskool op Whale Island, Portsmouth, opgerig. Die instrukteurs wat in hierdie skool diens 
gedoen het, is ook gedeeltelik aan die Britse Leërskool vir Liggaamlike Opleiding in Aldershot, opgelei. Oefeninge op die rekstok, die brug en oefeninge met handen stanggewigte sowel as knuppelswaaie het hul weg in die liggaamlike opleidingsleerplanne van die Britse vloot gevind.

Aan die destydse bevelvoerder en superintendent van gimnasia, adm. N. C. Palmer is opgedra om 'n deeglike studie van die metodes van liggaamlike opleiding wat in daardie tyd plaaslik en in die buiteland in swang was, te maak. By voltooiing van sy ondersoek moes adm. Palmer aanbevelings ten opsigte van genoemde vak aan die Britse vlootoutoriteite voorlê. Hierdie opdrag het hom dan ook spoedig in Swede gebring waar hy opleidingsmetodes in die vloot,- ander militêre en burgerlike inrigtings bestudeer het. Adm. Palmer se uiteindelike rapport het die Britse admiraliteit beweeg om die Sweedse stelsel in die Britse vloot in te voer $(35: 74)$.

Aan die begin van die huidige eeu is 'n begin by die R.N. Barracks Gymnasium te Portsmouth, gemaak met die opleiding van instrukteurs in liggaamlike opleiding deur Alan Broman, 'n Sweedse professor. Die stelsel wat hier toegepas is, is ontwikkel om by die behoeftes van die Britse seediens aan te pas en dit het die grondslag van liggaamlike opleiding vir die Britse vloot geword.

In 1905 is adm. Palmer deur adm. sir Hugh D. R. Watson opgevolg.

Tot 1900 was die Naval School of Physical Training in die R.N. Barracks, Portsmouth, gevestig, maar in 1910 het die Britse admiraliteit besluit dat 'n afsonderlike inrigting vir hierdie doel opgerig moes word. Die nuwe inrigting is dan ook op 22 September 1910 in Portsmouth geopen (35:75).

Vier jaar later is laasgenoemde skool gesluit as gevolg van die feit dat alle lede van die Britse vloot vir oorlogsdiens benodig was. In die volgende vier jaar, m.a.w. vir die duur van die Eerste Wêreldoorlog, is instrukteurs in liggaamlike opleiding nie aan hierdie inrgting opgelei nie.

In 1918 het die Britse admiraliteit besluit dat meer instrukteurs nodig is om die aanhoudende toevloei van rekrute in die Vloot op te lei om die baie belangrike fisieke en morele doeltreffendheid van die seesoldate en matrose te verhoog.

Kdr. B. T. Coote, 'n vlootoffisier wat oor baie ondervinding op die gebied van liggaamlike opleiding beskik het, is die taak opgedra om die skool te heropen. Hierdie offisier het in Swede studeer en hy het heelwat ondervinding as onderwyser aan die Britse privaatskole Harrow en Eton opgedoen (35: 75).

In 1920 is vooruitgang met die stigting van 'n Direktoraat van Liggaamlike en Rekreatiewe Opleiding vir die Britse vloot gemaak (35:76).

Die opleiding van Britse vlootoffisiere en instrukteurs in liggaamlike opleiding is volgens die Sweedse stelsel aan die skool in Portsmouth voortgesit. In die leerplanne is voorsiening vir lesings oor anatomie en fisiologie gemaak, terwyl onderrig in boks, skerm, bajonetgevegte, roei, swem, duik, lewensredding, atletiek en selfverdediging ook voorgeskryf is. Die organisasie van verskillende sportbyeenkomste en die prosedure wat gevolg moet word by die hou van vergaderings is ook tydens kursusse bespreek. Verder het die reëls van alle buitemuurse spele, veral hokkie en sokker, baie aandag op hierdie kursusse geniet. Van studente is verwag om 'n kwalifiserende eksamen as 'n sokkerskeidsregter af te lê.

Met verwysing na anatomie en fisiologie is noue skakeling met die mediese professie gehandhaaf. 'n Mediese dokter is op die personeel van die Britse vloot se Skool vir Liggaamlike Opleiding aangestel. Geen wysiging in die oefeninge of metode van onderrig wat in die Britse vloot gevolg is, kon sonder genoemde geneesheer se toestemming geskied nie $(35: 76)$. 
$\mathrm{Na}$ die heropening van die Britse vloot se Skool vir Liggaamlike Opleiding in 1918 en tot omstreeks 1939 het die Britse vlootowerhede voortgegaan met die opleiding van instrukteurs in liggaamlike opleiding. Dit het so goed gevorder dat offisiere in elkeen van die vier vlootkommandemente Portsmouth, Plymouth, Nore en Air een in elke vlootopleidingsinrigting en grotere vloot-lugmagstasies gestasioneer is. Hierbenewens is instrukteurs ook op skepe geplaas waar hulle aandag aan die fiksheid van die matrose, terwyl hulle aan boord die skepe is, moes skenk.

Die Britse admiraliteit het die waarde van fisieke fiksheid tot so 'n mate besef dat hulle in die moeilike jare van die Tweede Wêreldoorlog opdrag gegee het dat een sewende van die opleidingstyd in die opleidingsinrigtings vir rekrute aan liggaamlike opleiding bestee moes word $(45: 134)$.

In hierdie tyd moes' 'n offisier wat hom op die gebied van liggaamlike opleiding wou bekwaam 'n kort kursus van twee maande volg. Hierna is van sy dienste as sportoffisier aan boord van een van die Britse vloot se vaartuie of aan opleidings- of ander inrigtings op land gebruik gemaak. Indien so 'n offisier goeie resultatc op die kort kursus behaal en hy sy taak na wense verrig het, kon hy toegelaat word om 'n lang kursus van ses maande te volg (45:135-136).

Onderoffisiere wat 'n kursus as liggaamlike opleidingsinstrukteurs wou volg, moes eers as seemanne opgelei word. Daarna kon hulle, op voorwaarde dat hulle onder die ouderdom van 25 jaar, medies geskik en deur hoër gesag aanbeveel is, die kursus volg. Dit was 'n intensiewe kursus wat ses maande geduur en praktiese werk in gimnastiek, swem, skerm, boks en atletiek ingesluit het. Verder het die leerplan ook voorsiening vir lesings oor die teorie van gimnastiek en ander vertakkinge van dié vakgebied gemaak. Die mediese offisier het lesings oor mediese aspekte en eerstehulp waargeneem, terwyl aspekte soos die vermoë om 'n klas in liggaamlike opleiding te onderrig, deeglike aandag geniet het $(35: 136)$.

Nadat 'n lid in hierdie kursus geslaag het, is hy as 'n tweede klas liggaamlike opleidingsinstrukteur in die Britse vloot ingedeel. Hy kon later teruggeroep word om 'n verdere kursus van vier maande te volg.

Gedurende die oorlogsjare het die uitbreiding van die vloot meegebring dat liggaamlike opleidingskursusse aansienlik verkort is. Die toenemende Britse vlootbedrywighede het meegebring dat burgerlike persone genader is om as instrukteurs in liggaamlike opleiding op te tree.

Hulle het 'n kort aanpassingskursus gevolg om hulself vertroud te maak met die stelsel en metodes wat daardie tyd op die gebied van liggaamlike opleiding in die Britse vloot toegepas is. Sommige burgerlikes het selfs aanstellings as offisiere in die vloot gekry en ander wat oor die vereistes seemanskwalifikasies beskik het, is op Britse skepe aangestel. Gillibrand (35:136) vermeld dat hierdie maatreël beswaarlik daartoe kon bydra om in die toenemende behoeftes van 'n steeds uitbreidende vloot te voorsien. Hierdie toestand het tot aan die einde van die Tweede Wêreldoorlog voortgeduur.

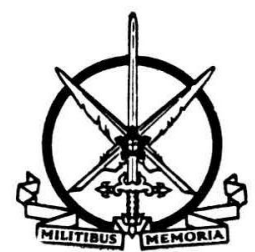




\section{Samevatting}

Brittanje se geografiese geïsoleerdheid en sy sterk vloot het daartoe bygedra dat die Britte nie soos baie ander volke na liggaamlike opleiding gegryp het om in hul militêre verdedigingsbehoeftes te voorsien nie. Dit, tesame met hul voorliefde vir sport en spele, het die ontwikkeling van liggaamlike opleiding tot aan die vorige eeu stadig laat vorder. Daarna het die militêre aspek van liggaamlike opleiding in die Britse leër, lugmag en vloot vinnig tot 'n hoë peil ontwikkel wat by die omstandighede en militêre diensvereistes van die Britse Weermag aangepas het.
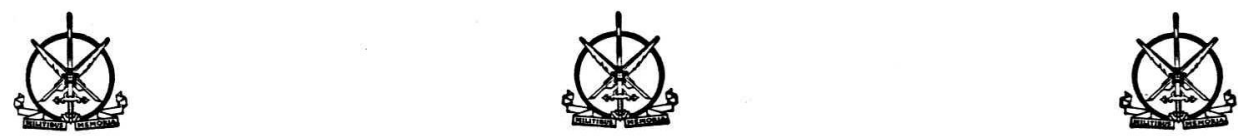


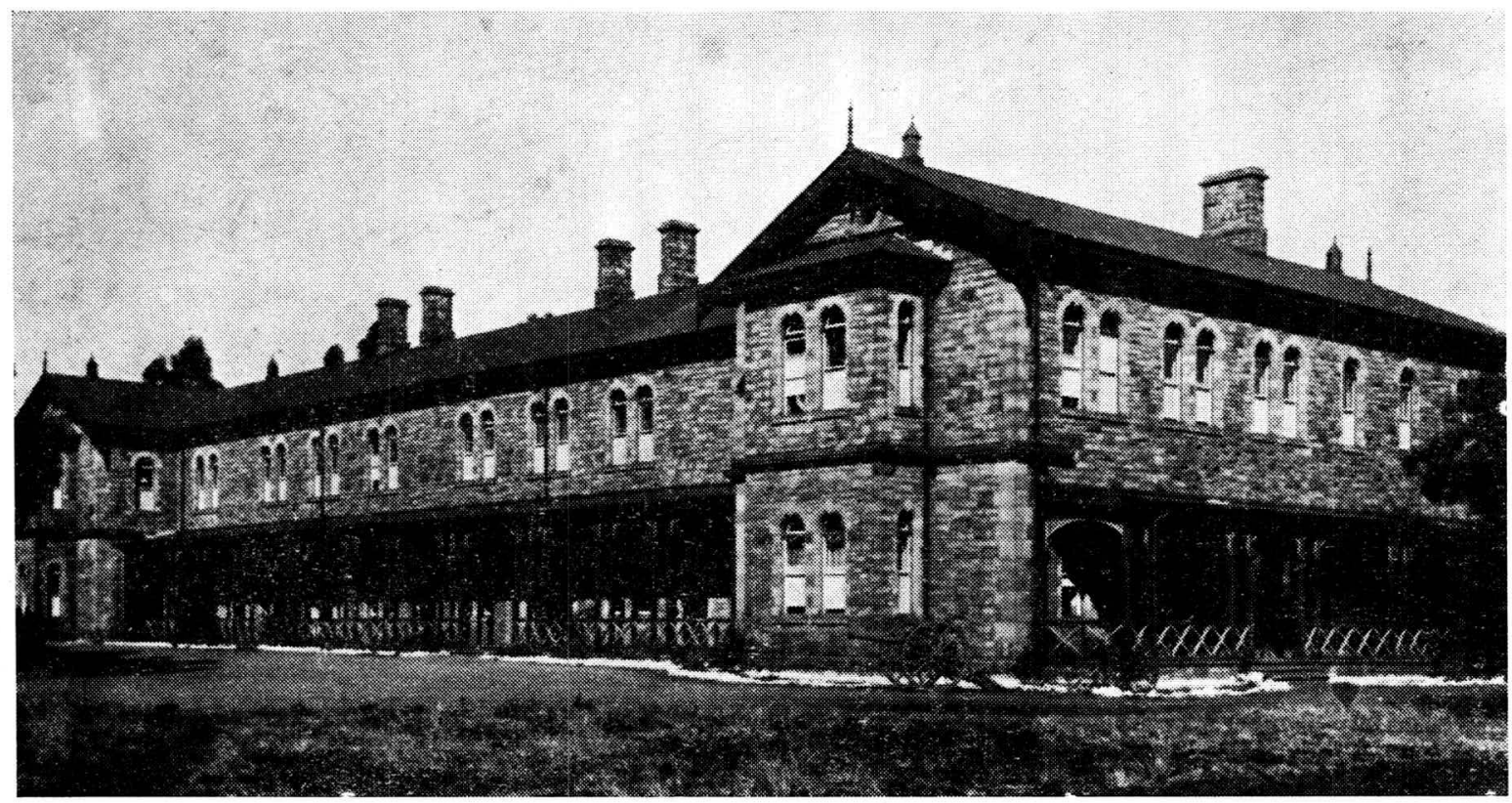

Die Zuidatrikanse Militaire School, Robertshoogte, omstreeks 1920.

Foto: M.H.A.D. 


\section{LIGGAAMLIKE OPLEIDING IN DIE UNIE-VERDEDIGINGSMAG}

\subsection{Inleiding}

Die goewerneur-generaal van die Unie van Suid-Afrika het op 13 Julie 1912 sy goedkeuring aan Wet No. 13 van 1912 - die Zuid-Afrika Verdedigingswet - verleen ingevolge waarvan die Unie-Verdedigingsmag, 'n bykans landsomvattende verdedigingsorganisasie, tot stand gekom het.

Die Suid-Afrikaanse regering sou voortaan aandag aan die op- en uitbou van die nuutgestigte verdedigingsorganisasie skenk. Vir een van die belangrikste aspekte van militêre opleiding, liggaamlike opleiding, sou ook voorsiening gemaak word.

\subsection{Die beginjare}

Die eerste bewys dat liggaamlike opleiding sy plek binne die raamwerk van die toenmalige militêre opleiding ingeneem het, vind ons kort na die totstandkoming van die Unie-Verdedigingsmag.

Op 30 Augustus 1912 het die destydse bevelvoerder van die Cape Mounted Riflemen vertoë tot die stafoffisier van die toenmalige inspekteur-generaal van die Unie-Verdedigingsmag gerig waarin hy versoek dat twee onderoffisiere toegelaat word om 'n kursus in liggaamlike opleiding in Pretoria by te woon. Hieruit blyk dit dat 'n soortgelyke kursus vanaf April tot Mei van dieselfde jaar in Suid-Afrika gehou is. Hierdie kursusse is by die Leërgimnasium op Robertshoogte, tans bekend as Voortrekkerhoogte, gehou. Hierdie militêre liggaamlike opleidingskursusse is deur die Imperiale magte aangebied, want reëlings is op 2 September 1912 deur die inspekteur-generaal van die Unie-Verdedígingsmag met die Imperiale militêre outoriteite getref vir die aanbieding van hierdie militêre kursus in liggaamlike opleiding in Suid-Afrika.

Die hoofkommissaris van die Suid-Afrikaanse Polisie is ook op 13 September 1912 genader om lede van die Polisiemag aan te beveel om aan die eersvolgende kursus, wat teen ongeveer die middel van Januarie 1913 sou begin, te laat deelneem. Sers. A. H. Smit, van die Natalse Polisie, en kpl. R. D. Scott, van die Cape Mounted Riflemen, is aangewys om aan bogenoemde kursus in liggaamlike opleiding deel te neem.

Die uiteindelike datum wat vir hierdie kursus neergelê is, het vanaf 1 April 1913 tot 31 Mei 1913, d.w.s. oor 'n periode van twee maande, gestrek.

Dokumentêre bewyse van die leerplan wat gevolg is, kon nie gevind word nie, maar die afleiding kan gemaak word dat hierdie kursus op die Britse militêre patroon georganiseer was, omdat dit deur die Imperiale magte. wat op daardie tydstip nog in Suid-Afrika was, aangebied is.

\subsection{Liggaamlike Opleiding in die Kadetkorps}

Die amptelike regulasies vir Kadetkorpse wat in 1913 met betrekking tot die Kadetkorps uitgevaardig is, het bepaal dat 'n seun wat by een van die Kadetkorpse aansluit ' $n$ kadet in die tweedeklas moes wees. Om bekwaam te wees, moet hy kwalifiseer in die verpligte onderwerpe en in een opsionele onderwerp van kursus 1 . Liggaamsoefeninge was een van die verpligte onderwerpe wat in die leerplan van kursus 1 ingesluit was $(77: 43)$. 


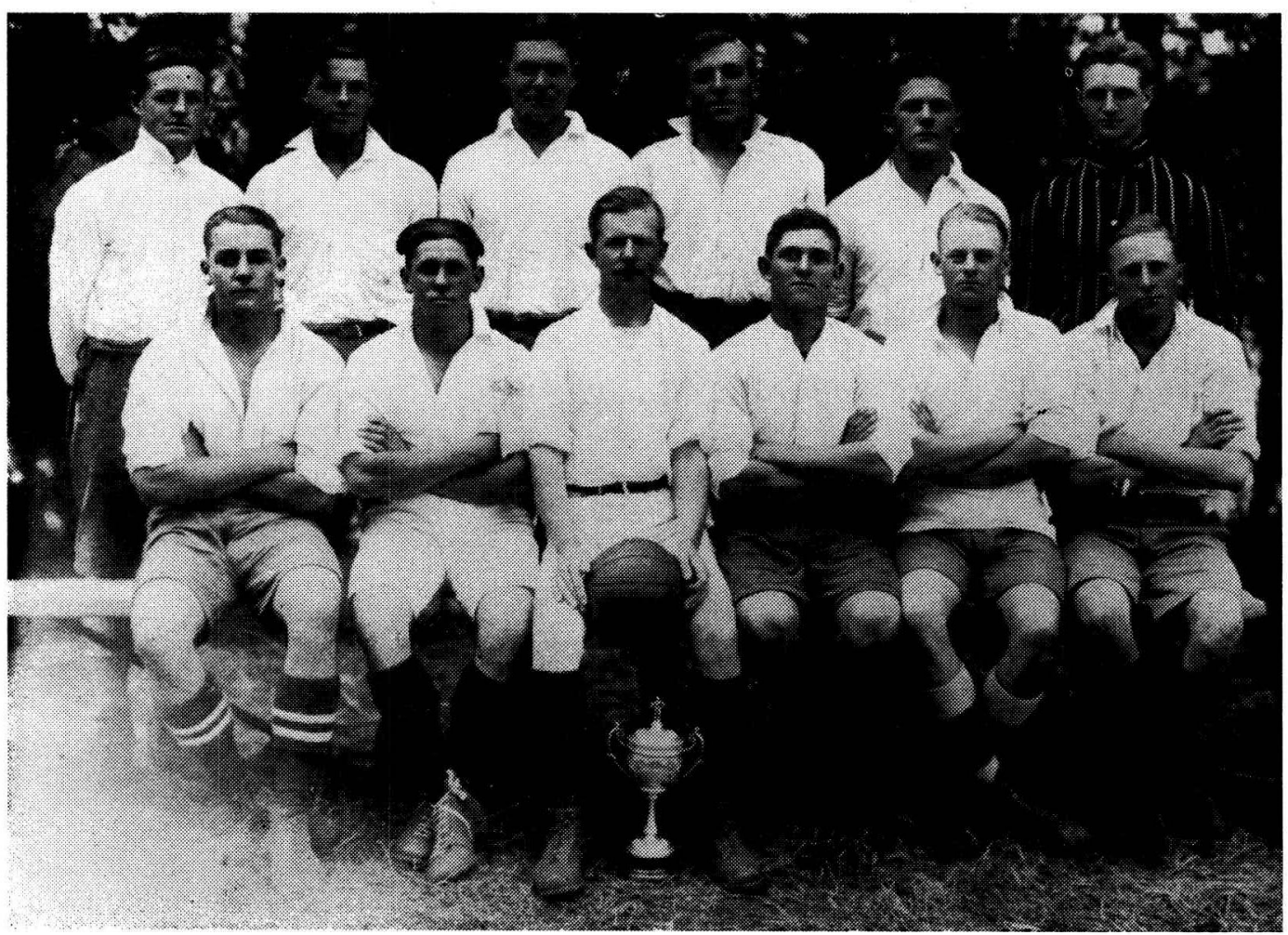

Left to Right Gunner M. J. Muller, Gunner H. Drew, Gunner C. J. Barnard, Bomb. H. R.

Standing: Hawkins, Gunner D. Jones (Vice-Captain), Bomb. S. P. du Toit (Hon. Secretary).

Sitting: $\quad$ Gunner R. A. Fowler, Driver J. M. v. d. Walt, B. S. M. G. W. Howes (Captain. Driver J. Risseeuw, Gunner G. L. Sprenger, Gunner J. J. Derry.

Photograph: The Gilham Studio, Pretoria/S.A.A.F. 
Voordat 'n tweedeklas kadet na die eersteklas kon oorgaan, moes hy kursus 2 voltooi waarvan liggaamsoefeninge ook 'n verpligte onderdeel gevorm het $(77: 43)$.

Militêre higiëne is as 'n verpligte onderwerp vir kursus 2 ingesluit, terwyl noodhulp 'n opsionele onderwerp in dieselfde kursus was $(77: 49)$.

Militêre higiëne het die volgende aspekte behels:

a. Sanitasie in die leër.

b. Oorsake van siektes,

c. Beginsels en voorkoming van siektes,

d. Water,

e. Voedsel,

f. Sanitasie van barakke $(77: 49)$.

Kadette moes $60 \%$ van die toekenbare punte behaal om te slaag.

Eersteklas kadette moes ' $n$ deeglike kennis van bestaande sowel as van die vernaamste siektes onder soldate, kleding, higiëne op mars en veldsanitasie hê $(79: 49)$.

Noodhulp het o.m. die volgende onderdele ingesluit:

a. Die behandeling van ' $n$ verskeidenheid beserings,

b. Verbindkuns,

c. Kunsmatige asemhaling,

d. Metodes om gewondes te dra,

e. Die vervoer per draagbaar.

In hierdie geval moes kadette $50 \%$ van die toekenbare punte behaal om te slaag $(77: 53)$.

Ten einde 'n onderskeidingsteken te kan verwerf, moes kadette 'n goedgekeurde eksamen in die volgende onderwerpe aflê:

a. 'n Kort beskrywing van die beenstelsel, spiere en slagare.

b. Die werking van die bloedsomloop en die asemhalingstelsel.

c. Die onderskeid tussen slagaar-, aar- en kapillêre bloeding en die wyses om bloeding in elkeen van die gevalle te laat ophou.

d. Die ligging van die groot slagare.

e. Sigbare tekens van beenbreuke en die behandeling daarvan.

f. Die vervaardiging van tydelike spalke.

g. Die behandeling van persone wat skynbaar verdrink of versmoor het.

h. Maniere om driehoekige verbande te lê.

i. Die behandeling van persone wat brandwonde opgedoen het of wie se klere brand; dié wat in 'n floute verkeer of 'n toeval gekry het.

j. 'n Metode om 'n gewonde te dra $(77: 53)$.

Van kadette in die tweedeklas is verwag om, gekleed in 'n hemp, 'n broek, 'n baadjie, kouse en seilskoene, 50 tree te kan swem. Kadette in die eersteklas moes onder dieselfde omstandighede 75 tree swem.

Ter verkryging van 'n sertifikaat van bedrewendheid moes 'n kadet 'n eksamen in reddingswem aflê wat deur deskundiges afgeneem sou word $(77: 53)$.

\subsection{Handleiding vir Liggaamlike Opleiding}

Liggaamlike opleiding was, sover aan die hand van beskikbare bronne nagegaan kon word, teen 1920 nog nie op 'n georganiseerde grondslag geplaas nie. Om in hierdie behoefte te voorsien, het die militêre owerhede in 1920 'n handleiding onder die naam Manual of Physcial Training saamgestel wat as basis vir 
hierdie soort opleiding in die Unie-Verdedigingsmag moes dien. 'n Konsep-handleiding in dieselfde jaar vir nasiendoeleindes aan die bevelvoerder aan die SuidAfrikaanse Militêre Skool, Robertshoogte, gestuur waarna dit dan in beide amptelike tale vertaal en gepubliseer sou word.

Die kommentaar wat in Maart van dieselfde jaar deur kapt. Buddens op hierdie voorgestelde handleiding gelewer is, toon dat die metode en samestelling daarvan dieselfde patroon gevolg het as die Manual of Physical Training wat deur die Britse Oorlogskantoor gepubliseer is.

Hierbenewens het dit ook aan die lig gekom dat die Manual of Physical Training 1908 (Reprint 1914) en 'n pamflet wat in verband met liggaamlike opleiding in 1918 deur die Britse Imperiale Generale Staf opgestel was ook in 1920 aan eenhede van die Unie-Verdedigingsmag vir gebruik uitgereik is.

Dit is dus duidelik dat daar op daardie tydstip nie 'n eie georganiseerde stelsel van liggaamlike opleiding in die Unie-Verdedigingsmag in swang was nie. Die beoogde handleiding het ewenwel as gevolg van finansiële en die feit dat ander vertaalwerk voorrang geniet het, nooit die lig gesien nie.

\subsection{Die Kursus van 1922}

Alhoewel bogenoemde pogings aangewend is om die liggaamlike opleiding in die Unie-Verdedigingsmag op 'n spesifiek Suid-Afrkaanse georganiseerde grondslag te plaas, was dit nie voor 1922 nie dat daadwerklike stappe gedoen is om meer aandag aan die opleiding van instrukteurs in hierdie vak te skenk. Met hierdie doel voor oё het die destydse Hoof van die Generale Staf, brig.-genl. A. J. E. Brink, op 27 April 1922 bekend gemaak dat daar in die toekoms meer aandag aan liggaamlike opleiding bestee en dat die metode van onderrig gestandardiseer word. On hierdie oogmerke te verwesenlik, sou 'n instrukteurskursus in liggaamlike opleiding aan die S.A. Militêre Skool, Robertshoogte (tans Voortrekkerhoogte), gereël word.

Van eenheidsbevelvoerders is verwag om die volgende Staande Maglede onder die rang van sersant te benoem om die voorgenome kursus te volg:

1 Z.A.B.S. : 5 lede,

Elke Permanente Battery : 3 lede.

Voorts het die Hoof van die Generale Staf op dieselfde dag aan die kommandant van die S.A. Militêre Kollege opdrag gegee om aan te dui wanneer die kursus aangebied kon word asook om voorstelle aangaande die duur van die kursus voor te lê.

Bevelvoerders van bogenoemde eenhede moes onverwyld verslag lewer oor die aard van die militêre liggaamlike opleiding wat op daardie stadium in gebruik was en tewens die name van instrukteurs op hul personeel verstrek wat voldoende kennis van die vak besit om hulself as instrukteurs te bekwaam.

Reëlings sou terselfdertyd getref word om 'n gimnastiek-instrukteur by die S.A. Militêre Kollege aan te stel met die doel om toesig oor alle aspekte van liggaamlike opleiding by die Leërgimnasium te hou. In hierdie verband is die Bevelvoerder van Robertshoogte versoek om 'n tydprogram saam te stel met die doel om alle eenhede in gimnastiekklasse te betrek. Dit het sowel studente wat kursusse aan die S.A. Militêre Kollege volg, as lede van die S.A. Lugmag ingesluit.

Die mediese offisier van Robertshoogte sou, vanuit 'n mediese oogpunt beskou, toesig oor die militêre liggaamlike opleiding uitoefen. 
S.A. MILITARY SCHOOL.

INSTRUCTORS' QUALIFYING COURSE, 1923.

GYMNASTIC SQUAD.

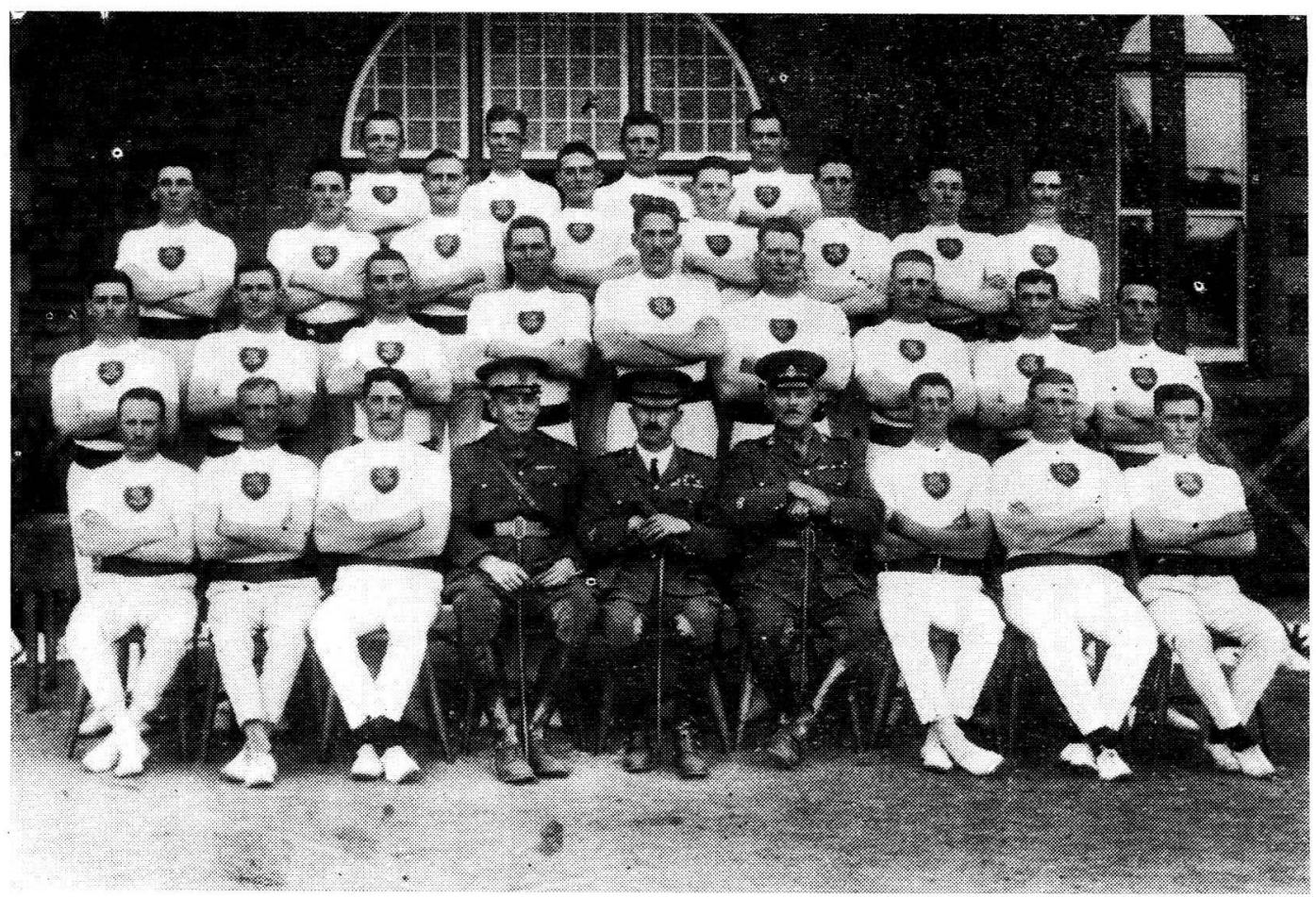

Back Row: L.Cpl. F. H. S. Cary, A.L.Cpl. D. A. Swart, A.L.Bdr. J. P. Lehmann, Bdr, W. C. Ross.

Third Row: A.L.Bdr. H. V. Glisson, A.L.Bdr. G. S. H. Park, Cpl. C. H. Prinsloo, A.L.Bdr. C. E. Brits, A.L.Bdr. S. van Ass, A.L.Bdr, S. P. du Toit, A.L.Bdr. M. S. Maasdorp, A.L.Bdr. L. J. Meintjes.

Second Row: L. Cpl. D. L. Elias, A.L.Bdr. N. L. Stidworthy, Cpl. J. C. Court, A.L.Bdr. W. M. Raubenheimer, A.L.Cpl. J. A. S. Bezuidenhout, A.L.Cpl. A. J. Bester, A.L.Bdi: A. D. de Wilde, L.Cpl. C. H. Badenhorst, A.L.Cpl. A. C. Jonker.

Front Row: $\quad$ Sgt. F. W. Borchers, S.I. P. J. Botha, S.S.I. W. V. Esment, Capt. G. E. Brink, D.S.O. (Adjutant), Lt.-Col. A. J. Taylor. C.M.G., D.S.O., M.C. (Commandant), S.M.I. L. Higginbothom (Instructor), S.I. S. E. du Toit, S.S.I. B. S. Scheepers, Sgt. H. J. Weber.

Photograph and Caption: Unknown/S.A.A.F. 
Die toestand waarin die militêre liggaamlike opleiding voor 1922 in die Unic verkeer het, word duidelik weerspieël in gegewens wat eenheidsbevelvoerders in antwoord op die voorgestelde skema verstrek het.

Die opleidingsprogramme van die Eerste Permanente Battery van die Zuid-Afrikaanse Bereden Schutters het nie voorsiening vir liggaamlike opleiding gemaak nie. Die bevelvoerder het in 'n skrywe van 4 Mei 1922 verklaar dat liggaamlike opleiding vir die laaste keer teen omstreeks Julie 1918 ter hand geneem was en dat daar ook geen instrukteurs was wat voldoende kennis van die vak besit het om as instrukteurs op die voorgenome kursus te kon kwalifiseer nie.

Ook die Derde Permanente Battery van die Zuid-Afrikaanse Bereden Schutters het op daardie stadium nie voorsiening in die opleidingsprogramme vir die uitvoering van liggaamlike opleiding gemaak nie, ja selfs nie vir enige vorm van liggaamlike opleiding nie. Die bevelvoerder het egter drie lede aangewys om aan die beoogde kursus deel te neem.

Die toestand by die Eerste Regiment Zuid-Afrikaanse Bereden Schutters het daar anders uitgesien. Op bogenoemde tydstip was daar instruksieklasse vir onderoffisiere in liggaamlike opleiding by dié eenheid aan die gang wat deur die bevelvoerder as voldoende beskou is. Hy het dit nie nodig geag dat instrukteurs benoem word om aan die voorgenome kursus deel te neem nie. Die feit dat daar nie 'n handleiding vir gebruik deur die instrukteurs bestaan nie, is op 5 Mei 1922 deur die bevelvoerder van laasgenoemde Regiment beklemtoon en hy het die militêre owerhede van die Unie-Verdedigingsmag gevolglik versoek om, hangende die voltooiing van die Unie-handleiding, 'n kopie van die Britse handleiding beskikbaar te stel. Op grond hiervan is eksemplare van die Manual of Physical Training (Reprint 1914) op 12 Mei 1922 aan 1, 2 en 3 Permanente Batterye asook aan 1 Regiment Zuid-Afrikaanse Bereden Schutters gestuur.

Teruggaande na die tydprogram wat opgestel moes word vir die gebruik van die gimnasium van die S.A. Militêre Skool deur eenhede vir liggaamlike opleiding, dien vermeld te word dat dié idee laat vaar is as gevolg van allerlei besware wat deur eenheidsbevelvoerders geopper is. As voorbeeld het die kommandant van die S.A. Militêre Skool aangevoer dat studente by genoemde inrigting nie betyds vir die volgende periode terug sal wees as hulle eers aan liggaamlike opleiding by die Gimnasium moes deelneem nie.

Met betrekking tot die voorgestelde kursus vir die opleiding van instrukteurs in liggaamlike opleiding het die kommandant van die S.A. Militêre Skool op 8 Junie 1922 aanbeveel dat jaarliks 'n kursus aangebied moet word om jong onderoffisiere die geleentheid te bied om as eenheidsinstrukteurs in hierdie vak te kwalifiseer. So 'n kursus moet ses weke duur en die leerplan moet die volgende insluit:

a. Sweedse dril, insluitende spele.

b. Sweedse dril met apparaat.

c. Gimnastiekoefeninge op die springkas, die rekstok, die brug en die ringe.

d. Gevegte met veerbajonette.

e. Anatomie soos benodig vanuit 'n liggaamlike opleidingsoogpunt gesien.

Voorts het die owerhede van die S.A. Militêre Skool aanbeveel dat rekrute elke werksdag 40 minute oefening moes ontvang. Indien apparaat beskikbaar was, moes bogenoemde periodes tot een uur verleng word. 'n Halfuur moes aan Sweedse dril en 'n halfuur aan apparaatwerk gewy word. 
Die S.A. Militêre Skool het die volgende apparaat benodig om die beoogde kursus in liggaamlike opleiding aan te bied:

a. Sweedse dril: Banke, muurrekke, ysterstang.

b. Gimnastiekapparaat: 'n Brug, 'n rekstok, 'n springkas, springplanke en neerkommatte.

c. Bajonetskerm: Veerbajonette, leer- en seilbaadjies, maskers, handskoene en lyfskerms.

d. Klerasie: Truie, broeke, gordels en seilskoene vir gebruik deur die instrukteurs.

Sers.-maj. L. Higgenbotham is beskikbaar gestel om as instrukteur tydens die kursus op te tree. Hierdie voormalige Britse onderoffisier het vanaf 28/1/1894$24 / 9 / 1912$ in 16th Lancers gedien en vanaf $21 / 9 / 1901-30 / 6 / 1912$ is hy deur die Imperiale leër aan die Koloniale Magte geleen. Vanaf 12 Junie 1920 het hy diens by die S.A. Militêre Skool op Robertshoogte gedoen. Sers.-maj. Higgenbotham het in 1896 'n eerste klas in 'n Army Fencing en Gymnastics-kursus in Indië behaal.

Dat hierdie onderoffisier 'n voortreflike instrukteur was, blyk uit 'n brief van gelukwense wat lt.-kol. J. Mitchell-Baker, van die Hoof van die Generale Staf se kantoor, op 16 Junie 1923 aan kol. A. J. Taylor, C.M.G., D.S.O., M.C., destydse kommandant van die S.A. Militêre Skool, geskryf het na aanleiding van 'n sportbyeenkoms wat op 2 Junie 1923 op Robertshoogte gehou is. In genoemde brief is sers.-maj. Higgenbotham veral gelukgewens met die hoë standaard van gimnastiek wat tydens genoemde sportbyeenkoms vertoon is.

Die aanbevelings van die kommandant van die S.A. Militêre Skool is op 19 Julie 1922 aanvaar en kursus no. 7G, die kwalifiserende kursus in Liggaamlike en Rekreatiewe Opleiding (S.A. Staande Mag), is vanaf 14 September 1922 tot 26 Oktober 1922 aan die S.A. Militêre Skool aangebied.

Dit was die eerste georganiseerde kursus, gebaseer op die Sweedse stelsel, wat in die Unie-Verdedigingsmag m.b.t. die opleiding van instrukteurs in liggaamlike opleiding aangebied is.

\subsection{Vooruitgang 1922-1924}

Die militêre owerhede was egter nie tevrede met die toedrag van sake op die gebied van liggaamlike opleiding in die Unie-Verdedigngsmag nie, ja selfs nie toe pogings reeds aangewend was om die instrukteurskursus van sers.-maj. Higgenbotham van stapel te stuur nie. Dit blyk duidelik uit 'n skrywe wat lt.-kol. J. Mitchell-Baker, C.B., C.B.E., D.S.O., Algemene Stafoffisier by Verdedigingshoofkwartier, op 25 April 1922 aan kol. R. B. Campbell, D.S.O., Inspekteur van Liggaamlike Opleiding te Aldershot, Engeland, gerig het. Een van die vernaamste probleme wat die militêre owerhede op Pretoria verhinder het om liggaamlike opleiding in die Unie-Verdedigingsmag op 'n eenvormige en goed georganiseerde grondslag te plaas, was die gabrek aan fondse. Nog 'n probleem wat die kommandant van die S.A. Militêre Skool insake die koördinering van liggaamlike opleiding in die Unie ondervind het, was die feit dat studente wat hulle by dié skool vir kursusse aangemeld het, kadetoffisiere was wat die opleidingsprogramme, soos deur die Departement van Onderwys in Transvaal neergelê, as onderwysers by hul onderskeie skole moes uitvoer. Die liggaamlike opleiding wat by die S.A. Militêre Skool aangebied was, het verskil van die onderrig wat by die skole gegee is. Dit het meegebring dat die onderwysers na voltooiing van kursusse aan bogenoemde inrigting die stelsel en metodes waarvolgens die oefeninge aan hierdie inrigting uitgevoer word, moes laat vaar. 
Die handleiding t.o.v. liggaamlike opleiding wat deur die Britse militêre outoriteite uitgereik is, was volgens lt.-kol. Mitchell-Baker te omvattend vir gebruik deur instansies wat nie oor die nodige apparaat, gimnastieksale en veral opgeleide instrukteurs beskik het nie.

Die allervernaamste vraagstuk waarmee die Suid-Afrikaanse militêre outoriteite ewenwel te kampe gehad het, was die gebrek aan behoorlik opgeleide instrukteurs.

Volgens lt.-kol. Mitchell-Baker was daar twee moontlike weë om laasgenoemde probleem te oorbrug:

Eerstens kon 'n geskikte offisier en onderoffisier na Aldershot gestuur word om ' $n$ volledige kursus in liggaamlike opleiding te volg en by hul terugkeer die opleiding van instrukteurs in die Unie-Verdedigingsmag ter hand te neem.

Die tweede moontlikheid was om die dienste van 'n Britse militêre instrukteur te verkry om liggaamlike opleiding in die Unie-Verdedigingsmag op 'n gesonde grondslag te plaas en om instrukteurs plaaslik op te lei.

In antwoord op die skrywe van 1t.-kol. Mitchell-Baker het kol. R. B. Campbell vcorgestel dat 'n offisier en twee onderoffisiere van die Unie-Verdedigingsmag gedurende die volgende jaar 'n kursus in liggaamlike opleiding aan die Britse inrigting te Aldershot bywoon, maar dat reëlings in die tussentyd getref kon word dat die dienste van 'n Britse offisier en twee onderoffisiere aan die Unie-Verdedigingsmag beskikbaar gestel word om 'n Skool vir Liggaamlike Opleiding in Suid-Afrika te open.

Die gevolg was dat maj. T. H. Wand-Tetley, van die Wiltshire Regiment, in 1923 na die Unie-Verdedigingsmag gesekondeer is. Hy het op 12 Oktober 1923 by die S.A. Militêre Skool, Robertshoogte, diens aanvaar.

\subsubsection{Kursus $18 G$}

Reëlings is getref dat Kursus 18G - Liggaams- en Ontspanningsoefeninge vir lede van die S.A. Staande Mag, op 1 November 1923 begin en op 2 Februarie 1924 ten einde geloop het.

Hierdie kursus het 696 periodes in beslag geneem en oor 68 werksdae gestrek met uitsluiting van 17 Desember 1923 en 'n vakansieperiode wat vanaf 23 November 1923 tot 2 Januarie 1924 geloop het.

D.s carste periode het on sesuur in die oggend begin. Pouses is toegelaat vir on byi cn middagete. Na die middagete tot om 5 uur was daar geen kursusaktiwiteite nie. Die laaste twee periodes het om 5 uur begin en tot 6.30 geduur.

\subsubsection{Die Leerplan}

Die leerplan wat maj. Wand-Tetley in 1923 vir hierdie kursus saamgestel het, het soos volg daaruit gesien:

1. Liggaamlike opleiding

a. Tien rekruut-lesprogramme (tegniek en leierskap).

b. Lesprogramme vir opgeleide soldate (tegniek en leierskap).

c. Lesprogramme vir kadette en lede van die Aktiewe Burgermag (tegniek en leierskap).

d. Interpretasies van Britse militêre skemas in liggaamlike opleiding.

e. Geïmproviseerde hindernisbaanopleiding.

f. Beoordeling van indiwiduele- en spankompetisies in liggaamlike opleiding. 


\section{Boks}

a. Lesprogramme vir rekrute.

b. Lesprogramme vir opgeleide soldate.

c. Praktiese herstelwerk en vervaardiging van uitrusting.

d. Die organisasie van toernooie.

e. Die organisasie van boks binne 'n eenheid.

f. Die inoefening van boksers insluitende padwerk.

g. Praktiese beoordeling van boksgevegte en die vakkundige bekwaamheid om as skeidsregters, tydhouers, e.d.m. op te tree.

h. Praktiese demonstrasie van boksreëls.

3. Stoei

a. Stoei volgens die Britse militêre metode (Bacon-styl).

b. Gevegte tussen ongewapendes.

c. Die organisasie van toernooie.

4. Atletiek

a. Tegniek en oefening in alle baan- en veldnommers.

b. Die organisasie van 'n atletiekbyeenkoms sowel ten opsigte van spanne as indiwidueel.

c. Spanatletiek-byeenkomste.

d. Die uitlê van landloopbane, metode van beoordeling, beheer, opteken van punte en kontrole.

e. Landloop, hase en honde.

f. Die uitlê van 'n 440 tree-atletiekbaan, 100 en 220 tree-bane en springbakke.

g. Beoordeling van baan- en veldnommers, opteken van punte, tydhou en optrede as afsetter.

h. Toutrek.

5. Gimnastiek

a. Behendigheid (tuimel).

b. Rekstok.

c. Brug.

d. Springkas.

6. Skerm

a. Praktiese skerm met die sabel.

b. Reëls aangaande skerm met die sabel.

c. Die organisasie van kompetisies.

7. Swem

a. Grondoefeninge.

b. Die onderrig in swem, duik en dryf

c. Reddingswem.

d. Die organisasie van kompetisies.

8. Netbal

a. Voorbereidende praktika.

b. Praktika.

c. Waarde wat netbal inhou vir die ontwikkeling van karakter.

9. Massering

Opleiding in massering.

10. Noodhulp

a. Opleiding volgens die leerplan van die St. John's Ambulance.

b. Die aflê van eksamens vir die St. John's Ambulance-sertifikaat. 
Verder is lesings oor die volgende onderwerpe ook ingesluit:

1. Liggaamlike Opleiding

a. Die leerplan van die kursus.

b. Die noodsaaklikheid, doel en oogmerke van liggaamlike ople:ding.

c. Afkortings en wenke aan instrukteurs.

d. Lesprogramme.

e. Die beoordeling van kompetisies in liggaamlike opleiding.

f. Die saamstel van lesprogramme.

g. Die skrywe van verslae.

h. Die soort liggaamlike opleiding wat die geskikste is vir die soldaat.

i. Die byhou van aantekeningboeke.

2. Rekreatiewe Opleiding.

a. Organisasie met betrekking tot boks, landloop en atletiek.

b. Spanatletiekbyeenkomste.

c. Die demonstrasie van boksreëls.

d. Vlagkompetisies binne 'n eenheid.

3. Lesings oor die volgende Mediese Aspekte.

a. Die skelet.

b. Die spiere van die liggaam.

c. Die sisteme van die liggaam.

d. Higiëne en sanitasie.

e. Die senustelsel.

f. Dieet en voedingswaardes.

g. Vermoeidheid.

h. Die ontleding van resultate van fisiologiese rekords wat gedurende die kursus gehou is.

4. Ander lesings

a. Die omvang van liggaamlike opleiding in die Unie deur lt.-kol. Mitchell-Baker.

b. 'n Praatjie deur die kommandant van die S.A. Militêre Skool.

c. 'n Praatjie oor die S.A. Olimpiese Vereniging.

d. 'n Lesing oor swem en die ontleding van bewegings deur mnr. Green, Superintendent van die Pretoriase swembad.

e. Die Boy Scout-beweging.

f. Die Y.M.C.A.

Sertifikate

Aan die einde van die kursus is sertifikate aan suksesvolle kandidate toegeken. Die sertifikaat het uit drie dele bestaan. Hierbenewens is daar ook van 'n puntestelsel gebruik gemaak om die kandidaat in een van die volgende klasse te deel:

Spesiaal

Eerste klas

Tweede klas

en Standaard
$100 \%$ tot $85 \%$;

$84 \%$ tot $75 \%$ :

$74 \%$ tot $60 \%$;

$59 \%$ tot $50 \%$

Deel I. In hierdie deel is gesertifiseer dat die student geklassifiseer word as:

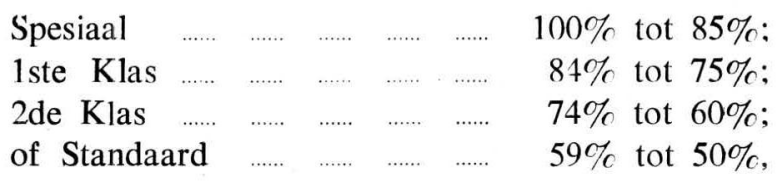


in liggaamlike en rekreatiewe opleiding. Laasgenoemde sluit die beginsels van boks, stoei, atletiek, skerm met die sabel en die organiseer van spele en kompetisies in.

In Deel II van die sertifikaat is gesertifiseer tot watter mate die student geklassifiseer is, d.w.s. spesiaal, 1ste klas, 2de klas of standaard in die volgende bykomende vakke:

Bekwaamheidstoetse in liggaamlike opleiding, boks, stoei, skerm, atletiek, swem en gimnastiek.

In Deel III is enige spesiale kwalifikasie vermeld wat die student met betrekking tot die volgende behaal het: Rugby, sokker, hokkie, krieket, skiet, roei, perdry, massage, noodhulp, die herstel en instandhouding van speelvelde en enige ander kwalifikasie wat nie op die sertifikaat aangedui word nie, insluitende oorlogsdiens.

\subsubsection{Eksamen, Toetse en Puntetoekenning}

Dit het uit twee dele bestaan:

In die eerste deel is die student beoordeel op grond van werk wat gedurende die kursus verrig is sowel as die eksamen wat aan die einde van die kursus afgelê is. Punte vir die eerste deel is soos volg toegeken:

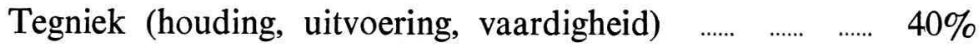

Leierskap (persoonlikheid, klashantering) _................ $40 \%$

Teorie (kennis van die beginsels van liggaamlike opleiding, elementêre anatomie en fisiologie ................ $20 \%$

Totaal $100 \%$

Die tweede deel het die klassifikasie volgens die volgende indeling behels:

\begin{tabular}{|c|c|c|c|c|c|c|}
\hline Spesiaal & ....... & $\cdots \cdots$. & $\cdots \cdots$. & $\cdots \cdots .$. & $\ldots$ & $100 \%$ tot $85 \%$ \\
\hline Iste klas & ...... & $\ldots$ & $\ldots$ & $\ldots \ldots$ & $\ldots$ & $84 \%$ tot 75 \\
\hline 2de klas & $\ldots$ & $\ldots \ldots$ & $\ldots \ldots$ & $\ldots \ldots$ & $\cdots$ & $74 \%$ tot \\
\hline Standaard & ....... & ..... & $\ldots . .$. & . & , & $59 \%$ \\
\hline
\end{tabular}

\subsubsection{Bekwaamheidstoetse in Liggaamlike Opleiding}

Hierdie toetsbattery het agt toetse ingesluit wat soos volg saamgestel is: Hardloop

1. 100 Tree

$$
\begin{array}{ll}
11.5 & \text { sek }=5 \text { punte } \\
12 & \text { sek }=4 \text { punte } \\
13 & \text { sek }=3 \text { punte } \\
14 & \text { sek }=2 \text { punte } \\
15 & \text { sek }=1 \text { punt }
\end{array}
$$

2. $3 \mathrm{Myl}$

$16.30 \min =5$ punte

$17.30 \mathrm{~min}=4$ punte

$19 \min =3$ punte

$21 \min =2$ punte

$23 \min =1$ punt 


\section{Spronge}

\section{Hoogspring}

$5 \mathrm{vt} 2 \mathrm{dm}=5$ punte
$4 \mathrm{vt} 10 \mathrm{dm}=4$ punte
$4 \mathrm{vt} 4 \mathrm{dm}=3$ punte
$3 \mathrm{vt} 9 \mathrm{dm}=2$ punte
$3 \mathrm{vt} 6 \mathrm{dm}=1$ punt

4. Verspring

19 vt $=5$ punte

$17 \mathrm{vt}=4$ punte

$16 \mathrm{vt}=3$ punte

$14 \mathrm{vt}=2$ punte

$13 \mathrm{vt}=1$ punt

Gooie

5. Gewigstoot met 16 pond gewig

$$
\begin{aligned}
& 35 \mathrm{vt}=5 \text { punte } \\
& 32 \mathrm{vt}=4 \text { punte } \\
& 27 \mathrm{vt}=3 \text { punte } \\
& 24 \mathrm{vt}=2 \text { punte } \\
& 21 \mathrm{vt}=1 \text { punt }
\end{aligned}
$$

6. Drie gooie na 6 vt teiken

$$
\begin{aligned}
10 \text { doele }=5 \text { punte } \\
8 \text { doele }=4 \text { punte } \\
6 \text { doele }=3 \text { punte } \\
4 \text { doele }=2 \text { punte } \\
2 \text { doele }=1 \text { punt }
\end{aligned}
$$

Klim

7. Touklim (sonder die gebruik van voete)

$$
\begin{aligned}
& 30 \mathrm{vt}=5 \text { punte } \\
& 25 \mathrm{vt}=4 \text { punte } \\
& 20 \mathrm{vt}=3 \text { punte } \\
& 15 \mathrm{vt}=2 \text { punte } \\
& 10 \mathrm{vt}=1 \text { punt }
\end{aligned}
$$

8. Klim oor 8 vt hoё muur

$$
\begin{array}{ll}
33 / 5 & \text { sek }=5 \text { punte } \\
4 & \text { sek }=4 \text { punte } \\
5 & \text { sek }=3 \text { punte } \\
6 & \text { sek }=2 \text { punte } \\
7 & \text { sek }=1 \text { punt }
\end{array}
$$

\section{Uitvoering van toetse}

1. Alle toetse word in seilskoene, onderhemde en kortbroeke uitgevoer.

2. In toets no. 6 word 'n krieketbal vanaf 'n merk 90 voet vanaf die teiken na die middelpunt van die teiken gegooi. Die teiken is in twee sirkels gemerk. Vyf punte word toegeken vir 'n kolskoot, 3 punte vir n' treffer binne die twee sirkels en 1 punt wanneer die teiken buite die buitenste sirkel raak gegooi word.

3. Die uitgangshouding vir toets no. 7 is vanuit die sittende posisie.

4. In toets no. 8 begin die toetsling uit die hanghouding, arms gestrek en die voete van die grond af. 
Boks-, Stoei en Skermtoetse

Die puntetoekenning vir hierdie toetse was soos volg saamgestel:

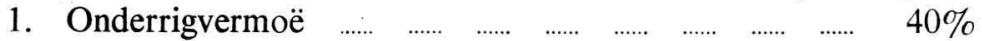

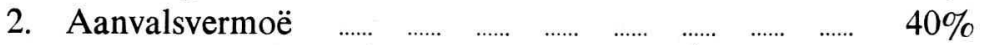

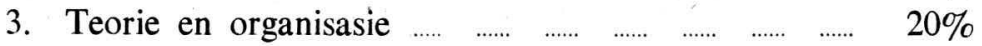

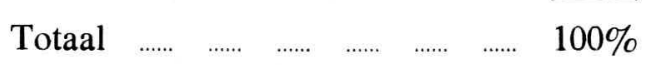

Atletiektoetse

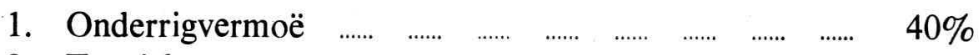

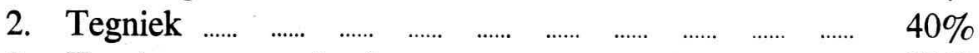

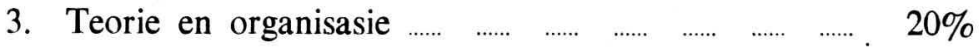

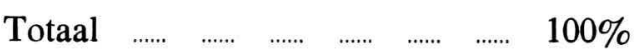

Swemtoetse

1. Standaard

a. Swem 100 tree borsslag.

b. Swem 50 tree rugslag.

c. Duik vanaf die rand van die swembad uit die staande posisie.

2. Tweede klas

a. Swem 100 tree syslag met arm oor.

b. Swem 100 tree sukkelgang of kruipslag.

c. Duik: i. Met aanloop vanaf veerplank.

ii. Duik vanaf 'n 12 vt hoë plank sonder aanloop.

iii. Spring vanaf 'n 12 vt hoë plank.

iv. Onderrigvermoë in borsslag en een soort rugslag.

3. Eerste klas

a. Verwerf die bronsmedalje van die Royal Life Saving Society.

b. Vermoë om syslag, sukkelgang en duik te onderrig.

4. Spesiaal

b. Onderrigvermoë in 'n ander soort rug- en kruipslag.

a. Meriete-toekenning van die Royal Life Saving Society.

c. Vermoë om 'n klas vir die bronsmedalje in lewensredding te toets.

\section{Gimnastiektoetse}

Omdat hierdie kursus in Engels aangebied was en om 'n ware weergawe van die militêre terminologie wat in daardie tyd in gebruik was te gee, word die gimnastiek toetse in Engels aangedui.

Genoemde toetse het die volgende behels:

Standaard (Standard)

\section{Horizontal Bar (Rekstok)}

1. Straight arm hang - underswing - travel to right or left - moving hands at end on backswing - 3 paces - drop at end of 4th backswing.

2. Right leg acting - left leg acting - left leg on and sit swing off.

3. Upstart - shoot to the front.

4. Clear circle.

5. Straight arm hang - steady circle above bar keeping legs straight down to hang position - bend knees and circle arm leading - down to hang position - left arm leading - vault right or left. 
Parallel Bars (Brug)

1. Position at front end of bars - swing moving hands at end of backswing - 6 paces - clear bar to front.

2. Swinging backlift.

3. Swing to bent arm balance - swing down and rest on bar in front backlift off one bar.

4. Position at end of bars in front - 3 paces - swinging backlift. Horse (Perd)

1. Bent back backlift (Horse broadways).

2. On one foot and backlift (Horse lengthways).

Rope Climbing (Touklim)

Left hand and right foot leading - 20 feet - feet off - down hand under hand.

Agility (Tuimel)

Dive over rope (3').

Shelf (Rakklim)

Both fore-arms leading.

Tweede Klas

Horizontal Bar (Rekstok)

1. Clear circle - upstart - clear circle - splits up and hook swing off.

2. Steady circle above bar - down to straight arm hang, to both hands leading grip position - both hands leading - hollow back - back lift.

Parallel Bars (Brug)

1. Position at end of bars - swing to bent arm balance - swing down and rest on both bars in front - hands forward and swing to straight arm - balance - swing down and rest on one bar in front - Tobins hop.

\section{Horse (Perd)}

1. Hollow back between the hands (Horse broadways).

2. Round back between the hands (Horse lengthways).

Rope Climbing (Touklim)

Both hands leading - hands and feet.

Agility (Tuimel)

1. Headspring.

2. Handspring.

Eerste klas

\section{Horizontal Bar (Rekstok)}

1. Straight arm hang - under swing - back up - clear circle - leg acting - change round on top of bar to sit swing position - sit swing round - full back-sitting upstart - clear circle - splits up and kick off.

2. Right, left and both arms leading - front roll to straight arm hang raise insteps to bar - legs straight - bend knees and pass feet between hands - straighten knees - back pull over bar - attention drop. 


\section{Parallel Bars (Brug)}

Back to straight arm balance - lower to bent arm balance - swing down and circle left leg to right hand - then circle right leg over right bar and on to left bar - turning body left about - hands forward swing to straight arm balance - half change, and back lift.

Horse (Perd)

1. Hollow hack, backlift (Horse broadways).

2. Scissors (Horse lengthways).

Rope Climbing (Touklim)

Hand-over-hand without feet (20 feet).

Agility (Tuimel)

1. Back upstart.

2. Hollow back handspring.

3. Back roll to long arm balance.

Spesiaal

\section{Horizontal Bar (Rekstok)}

1. Clear circle - underswing - back up - short circle - clear circle leg acting and turn on to both feet - two feet and hands grind - drop into hooks - sit swing round - hook swing round - sitting upstart - clear circle splits up and hollow back kick off or after sitting upstart underswing and front away.

2. Upstart - short circle to straight arm - three long swings and back away.

3. Slow circle above bar - slow forward roll above bar - down to straight arm hang - bend knees - circle under bar to back hang lift to back plant - bend back and pass feet under bar - straighten knees - pull over bar to position - steady lift to short arm balance and backlift.

\section{Parallel Bars (Brug)}

Upstart to straight arm balance - front roll to straight arm balance lower to bent arm balance - straight arm change - march backwards to end of bars - back clip out.

Horse (Perd)

1. On one foot to attention, back or front somersault.

2. Hollow back, backlift (Horse lengthways).

Rope Climbing (Touklim)

Hand-over-hand, legs at plant (20 feet).

Agility (Tuimel)

Running somersault.

Enersyds was in hierdie leerplan, soos opgestel en aangebied deur maj. Wand-Tetley, weliswaar al die belangrikste aspekte van liggaamlike opleiding verwerk, maar andersyds was daar, veral wanneer ons huidige opvattings in dié verband in aanmerking geneem word, ook sekere tekortkomings.

O.i. is daar te veel klem op persoonlike prestasie en te min op teoretiese kennis gelê. Verder is $40 \%$ van die totale puntepersentasie aan leierskap toegeken. Alhoewel leierskap 'n baie belangrike militêre aspek is, is dit ewenwel vaag op watter wyse die persoonliksheidsbeoordeling geskied het. 
Die sekondering van bogenoemde Britse offisier na die Unie-Verdedigingsmag het tot gevolg gehad dat die Britse invloed op die gebied van militêre liggaamlike opleiding in die Unie-Verdedigingsmag wortel geskiet het. Andersyds het sy werk, vakkundig gesien en met betrekking tot die toenmalige peil van ontwikkeling in die Unie-Verdedigingsmag, vooruitgang beteken.

\subsection{Die Tweede lang kursus in Liggaamlike en Rekreatiewe Opleiding}

'n Tweede lang kursus in liggaamlike opleiding en rekreatiewe opleiding, kursus 19G, het oor die tydperk 18 Februarie 1924 tot 26 Mei 1924 uitgestrek. 'n Totaal van 604 periodes is aan hierdie kursus gewy. Maj. Wand-Tetley was weereens die kursusleier.

Die leerplan wat gedurende hierdie kursus gevolg is, was dieselfde as dié van die vorige kursus, maar die volgende veranderings is in die leerplan aangebring:

Skerm is vervang deur lesings oor perdesport. Benewens die lesings oor perdesport is alle vorme van dié sportsoort insluitende die organiseer en beoordeling van items tydens byeenkomste prakties beoefen.

Die belangrikheid van albei hierdie lang kursusse lê daarin dat die grondslag vir die opleiding van toekomstige instrukteurs in liggaamlike opleiding in die Unie-Verdedigingsmag gelê is.

Behalwe dat maj. Wand-Tetley in bogenoemde verband toekomstige instrukteurs uit die geledere van die S.A. Staande Mag opgelei het, is hy ook versoek om lesprogramme vir gebruik deur lede van die Aktiewe Burgermag in opleidingskampe saam te stel. Hierdie lesprogramme, wat later in breë trekke bespreek sal word, moes die basis vorm waarop die fiksheidspeil van die soldate van die Unie-Verdedigingsmag opgebou moes word.

Genoemde offisier het 6 lesprogramme saamgestel wat soos volg versprei is:

1. Ses afskrifte van die lesprogram is aan elke Berede Regiment of Infanteriebataljon wat vredestydse opleiding ondergaaan het, gestuur.

2. Drie afskrifte het na elke eenheid wat 'n ander opleiding as in (1) hierbo ontvang het, gegaan.

3. Een afskrif is aan elke lid van die S.A. Instruksionele Korps wat op personeel van eenhede gedien het, gestuur.

Alvorens tot die beskrywing van die lesprogramme oorgegaan word, moet die volgende gedagtes van maj. Wand-Tetley onthou word:

By die samestelling van hierdie lesprogramme het hy gedink aan opleidingskampe wat 30 dae sou duur, terwyl vir kampe wat 10 dae geduur het nie meer as die eerste twee lesprogramme gevoeg moes word nie. Geen lesprogram moet vir minder as vier agtereenvolgende periodes aangebied word nie.

Hy het verder aanbeveel dat periodes van 30 minute elk op elke werksdag, voor ontbyt, aan liggaamlike opleiding bestee moet word op voorwaarde dat iets voor die aanvang van die oefeningperiode genuttig word.

Voorts het maj. Wand-Tetley aanbeveel dat die soldate wat die opleiding ondergaan in klasse van 30 opgestel word met een instrukteur in beheer van elke klas en dat 'n opgeleide offisier algemene toesig hou.

Die moontlikheid dat uitrusting soos bankies verskaf kan word en rowwe springbakke ingerig kan word, is ook met die opstel van die volgende lespro- 


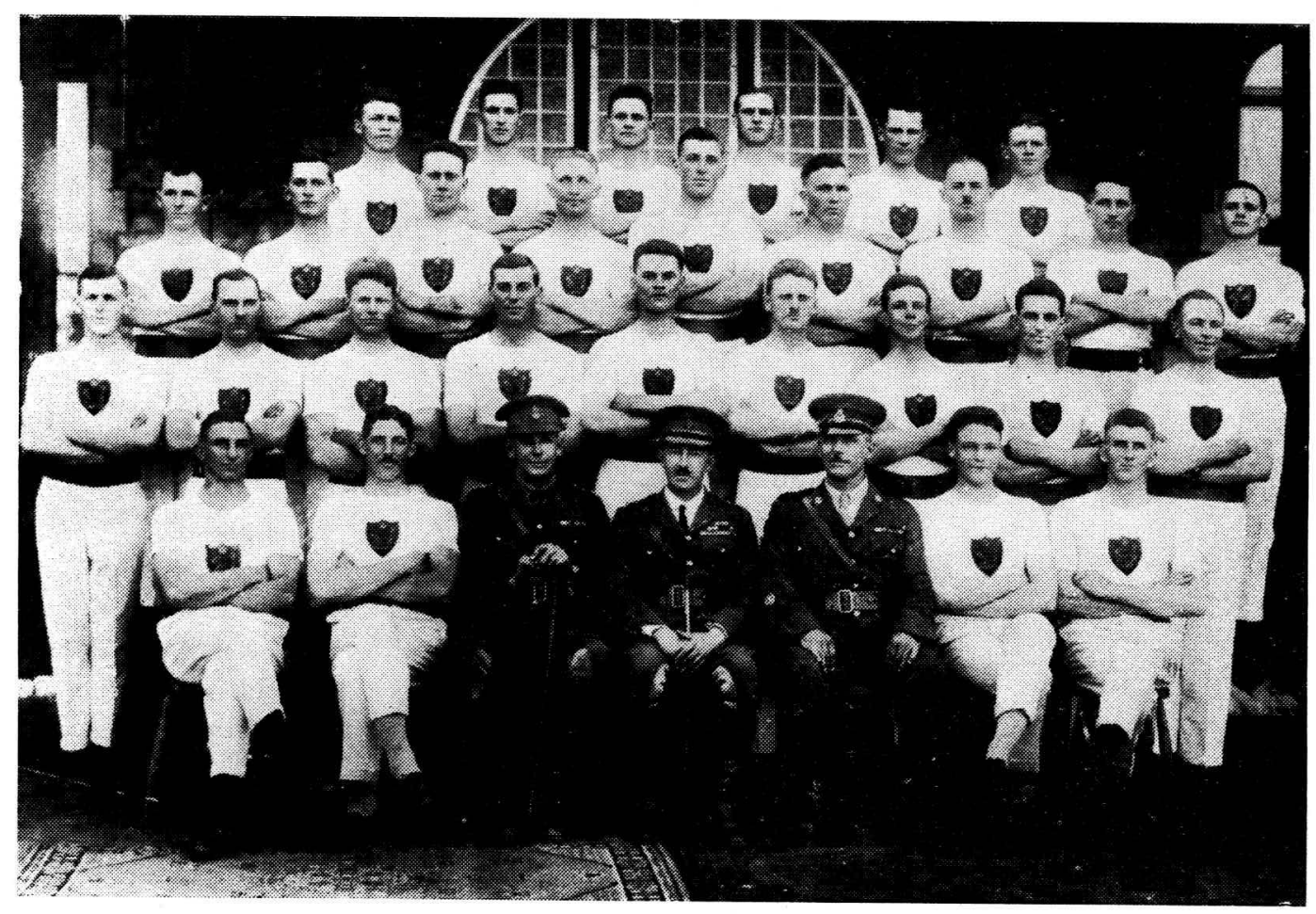

First Row: Cpl. L. E. Bowker, S.S.I. W. E. Estment, Capt. G. E. Brink, D.S.O. (Adjutant), Lt.-Col. A. J. Taylor, C.M.G., D.S.O., M.C. (Commandant), S.M.I. L. Higginbotham (College Sgt./Maj.), Cpl. J. F. du Plooy, Cpl. C. J. Rijff.

Second Row: L.Bdr. N. L. Stidworthy, Bdr. J. L. Muller, L.Cpl. J. H. Nell, L.Bdr. T. J. Smith, L.Cpl. A. E. van Niekerk, L.Bdr. A. D. de Wilde, L.Cpl. A. G. MacRae, L.Cpl. L. C. Heroldt, L.Cpl. C. J. van Aswegen.

Third Row: L.Bdr. C. de W. Engenbrecht, L.Cpl. I. F. Ferreira, L.Cpl. L. J. Haveman, L.Cpl. J. H. van der Merwe, L.Bdr. G. S. du T. Nel, L.Cpl. A. H. Havenga, L.Cpl. C. J. Snyman, L.Bdr. E. Troskie, L.Bdr. J. F. Carr.

Fourth Row: Cpl. J. E. Wiyson, Cpl. L. Symes, L.Bdr. H. G. R. Coxwell, L.Bdr. W. C. Stoop. Bdr. J. H. Jordaan, L.Bdr. A. Impey.

Photograph and Caption: Kassel Bros., Krugersdorp/S.A.A.F. 
Elkeen van die 6 lesprogramme was soos volg opgebou:

\section{Inleidende Oefeninge}

1. Marsjeer.

2. Uitgangshoudings.

3. Houdingsoefeninge.

4. Lenigheidsoefeninge vir die arms.

5. Lenigheidsoefeninge vir die bene.

\section{Algemene Oefeninge}

1. Balans.

2. Lenigheidsoefeninge vir die romp.

3. Handgemeen.

4. Hardloop-, spring- en behendigheidsoefeninge.

\section{Finale Oefeninge}

1. Marsjeer.

2. Korrekte asemhaling.

3. Houding.

Hierdie lesprogramme het 'n formeel militêre inslag gehad en oefeninge is op bevel van die instrukteur uitgevoer.

Maj. Wand-Tetley het na afloop van vermelde twee kursusse op 14 Julie 1924 na Engeland teruggekeer.

Soos reeds vermeld, was die doel van die sekondering van maj. WandTetley om instrukteurs in liggaamlike opleiding uit die geledere van die S.A. Staande Mag op te lei, om dié vak in die Unie-Verdedigingsmag op 'n georganiseerde grondslag te plaas asook om 'n Skool vir Liggaamlike Opleiding tot stand te bring. Hierdie doelstellings is egter slegs gedeeltelik verwesenlik nadat 'n paar instrukteurs opgelei en lesprogramme vir liggaamlike opleiding in die Unie-Verdedigingsmag versprei is.

Die oprigting van 'n Skool vir Liggaamlike Opleiding is egter op hierdie stadium nie verwesenlik nie.

As gevolg van ongenoemde redes het liggaamlike opleiding in die verdedigingsorganisasie van Suid-Afrika in die daaropvolgende jare weer in die vergetelheid geraak.

\subsection{Die Unie-Verdedigingsmag en die Winterolimpiade van 1929}

Terwyl die liggaamlike opleiding in militêre kringe in Suid-Afrika na maj. Wand-Tetley se baanbrekerswerk 'n dieptepunt begin nader het, is dit van belang om te vermeld dat daar in 1927 uit die buiteland 'n uitnodiging deur die Internasionale Olimpiese Komitee aan die Sekretaris van Buitelandse Sake van die Unie van Suid-Afrika gerig is om aan 'n internasionale militêre skikompetisie deel te neem. Hierdie wedstryd was 'n spesiale item op die program van die Winterolimpiade wat vanaf 11 tot 19 Februarie 1929 in St. Moritz, Switserland, gehou is. Bepaal is dat 'n span van drie lede en 'n leier lede van die Leër van die land moet wees wat deur hulle verteenwoordig word. Elke staat moes sy eie span se uitrusting voorsien en die onkoste betaal. Die afstand waaroor geski sou word, was $20-30 \mathrm{~km}$. Diplomas sou uitgereik en goue-, silwer en bronsmedaljes toegeken word.

As gevolg van die feit dat die Suid-Afrikaanse klimaat nie praktiese skioefeninge moontlik maak nie, kon die uitnodiging nie aanvaar word nie. 
ARTILLERY BARRACKS CRICKET TEAM.

WINNERS GARRISON INTER-UNIE LEAGUE - 1927.-1928.

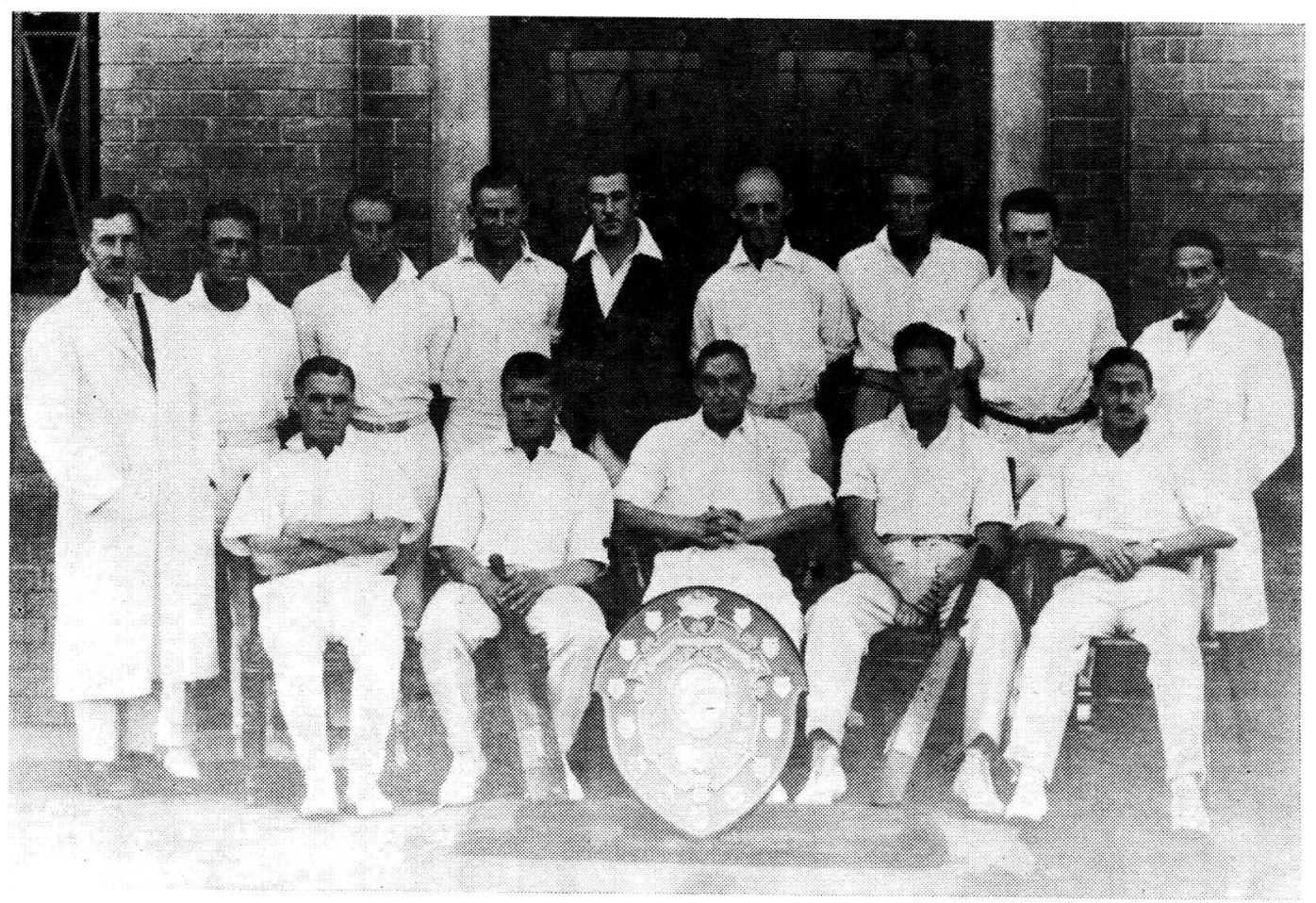

Front Row Sub-Conduc or M. J. Conner, Sgt. C. C. Wilson, Sub-Conductor A. J. Cook (Sitting): (Captain), Private J. Maguire, S.Sgt. S. Joffe.

Back Row S.Q.M.S. F. J. Parker (Umpire), Sgt. W. C. Crosson, Bdr. C. J. Botha, Private

(Standing): G. Berning, Cpl. J. D. Wallace (Scorer), Sgt. L. Cohen, Private J. Hearne, Aem./ App. R. Hart, Sub-Conductor G. Stroud (Umpire).

Photograph and Caption: Unknown/S.A.A.F. 


\section{Samevatting}

Sedert die wordingsjare van die Unie-Verdedigingsmag was die taak om die soldat liggaamlik fiks te kry vir sy moeilike taak an eenheidsbevelvoerders toeverirou wat nie die waarde van liggaamlike opleiding besef het en nie vakkundig opgelei was nie. Gevolglik is daar nie veel gedoen om die vak in S.A. militêre kringe op en uit te bou nie.

Hierdie toestand het voortgeduur tot in 1922 toe 'n kursus vir die opleiding van instrukteurs in liggaamlike opleiding aan die S.A. Militêre Skool aangebied is. Gedurende 1923-24 is twee lang kursusse deur maj. Wand-Tetley, 'n Britse offisier wat na die Unie-Verdedigingsmag gesekondeer is, ook by bogenoemde inrigting cangebied. Alhoewel laasgenoemde offisier 'n aantal instrukteurs tydens hierdie twee kursusse opgelei en 'n reeks lesprogramme vir lede van dic Unie-Verdedigingsmag soumgestel het, is die vak egter nie op 'n behoorlik georganiseerde grondslag geplaas nie.
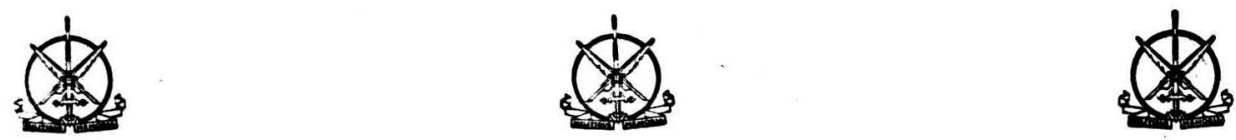


\section{DIE OPLEIDING VAN INSTRUKTEURS IN LIGGAAMLIKE OPLEIDING: 1928-1936}

\subsection{Inleiding}

Sedert die twee lang kursusse wat deur maj. Wand-Tetley in 1923-1924 aan die S.A. Militêre Skool gehou is, is verdere instrukteurskursusse in liggaamlike opleiding nie meer in die Unie-Verdedigingsmag gehou nie. Voorlopig is hierdie taak deur die S.A. Polisie oorgeneem.

\subsection{Pogings: 1928 tot 1930}

Gedurende die tydperk 1928-1930 is, in samewerking met die kommissaris van die S.A. Polisie, militêre personeel op kursusse in liggaamlike opleiding aan die destydse S.A. Polisiedepot in Pretoria geplaas. Die kursus wat in 1929 gehou is, het op 3 Desember 1929 begin en is tot in Januarie 1930 verleng. Die leerplanne wat tydens hierdie kursusse gevolg is, kon weliswaar nie opgespoor word nie, maar die feit dat kursusse gehou is, bewys in elk geval dat die liggaamlike opleiding in militêre kringe nie heeltemal stilgestaan het nie.

\subsection{Herlewing in 1932}

Die opleiding van liggaamlike opleidingsinstrukteurs vir die Unie-Verdedigingsmag het vanaf 1932 meer aandag geniet as sedert 1924 die geval was. Die owerhede van die Unie-Verdedigingsmag het ook in hierdie verband weereens vertoë tot die kommissaris van die S.A. Polisie gerig waarin versoek is dat militêre instrukteurs toegelaat word om 'n kursus in liggaamlike opleiding aan die S.A. Polisie Opleidingsdepot by te woon wat op 3 Oktober van dieselfde jaar sou begin. Dit het tot gevolg gehad dat sers. S. J. van der Berg, knr. J. M. Schmidt en o-bdr. W. E. Wocke aangewys is om hierdie kursus te volg, terwyl Wocke en Schmidt toegelaat is om die kursus, wat intussen na 9 maande verleng is, te voltooi.

In November 1933 is reëlings getref dat militêre instrukteurs 'n verdere kursus in liggaamlike opleiding aan die S.A. Polisie Opleidingsdepot kon volg wat op 2 Januarie 1934 sou begin.

Lede wat dié kursus volg, moes die volgende uitrusting in hul besit hê: Wit seilskoene, twee swart kortbroeke, twee kakie-langbroeke en ses gimnastiekonderhempies.

Op 14 Desember 1933 het die Hoof van die Generale Staf, genl.-maj. A. J. Brink, D.T.D., D.S.O., die S.A. Polisie versoek dat die aantal militêre kursusgangers na 8 of 10 vermeerder word en dat hulle die kursus wat op 1 Maart 1934 sou begin, bywoon. Die gevolg was dat ondergenoemde 12 lede van die Unie-Verdedigingsmag hulle op 1 Maart 1934 by die S.A. Polisie Opleidingsdepot aangemeld het om hierdie kursus te volg: Sers. C. P. Bester, kpls. J. Wallis, F. P. Smit, J. C. D. Bell, o-kpl. J. J. D. Nortje, t-o-bdr. P. J. Coetzee, knrs. E. Chemaly, J. W. van der Nest, J. L. Smith en o-bdr. P. C. McHeath.

Hierdie kursus is ook tot 9 maande verleng en 6 studente is toegelaat om die verlengde kursus te volg. Hulle is: Sersante L. A. Carelsen, F. J. Lotter, F. P. Smit, J. Wallis, C. Bester en J. Bell. 


\subsubsection{Die Leerplan}

Omdat hierdie kursus nie by 'n opleidingsinrigting van die Unie-Verdedigingsmag aangebied was nie, is dit noodsaaklik om die leser in te lei in die werk wat die militêre personeel by die S.A. Polisie Opleidingsdepot op die gebied van liggaamlike opleiding verrig het. Om hierdie rede word die leerplan hier aangedui. Daar sal tewens 'n poging aangewend word om bykomende onderwerpe en verskille in die leerplan wat in 1923 deur maj. Wand-Tetley opgestel was en dié van die S.A. Polisie-opleidingsdepot na vore te bring.

Tegnieke ten opsigte van die volgende onderwerpe is in die leerplan van die S.A. Polisie ingesluit:

\section{Liggaamlike Opleiding}

a. Drie lesprogramme in liggaamlike opleiding (Aldershot-tegniek en leierskap).

b. Drie lesprogramme in liggaamlike opleiding (Deense lesprogramme, tegniek en leierskap).

c. Liggaamlike opleiding soos dit in Europa gedoen is.

d. Massa-liggaamlike opleiding en figuurmarsjeerwerk.

e. Interpretasies ten opsigte van militêre skemas in liggaamlike opleiding.

i. Beoordeling van individuele- en spankompetisies in liggaamlike opleiding.

g. Toetse in liggaamlike opleiding.

2. Kompetisies: Spanspele

a. Waarde van spele.

b. Reël van spele.

3. Hindernisopleiding

a. Waarde van dié opleiding.

b. Aanbieding van hindernisopleiding.

c. Vervaardiging van hindernisse (binnenshuis en in die opelug).

4. Boks
a. Rekruutlesprogramme.
b. Reëls van die Internasionale Boksvereniging en die S.A. Nasionale Amateur Boksvereniging.
c. Optrede as beoordelaar en skeidsregter.
d. Pligte van helpers en tydhouers.
e. Die organisasie van toernooie.

5. Atletiek
a. Tegnieke ten opsigte van al die baan- en veldnommers.
b. Die organisasie van 'n atletiekbyeenkoms.
c. Bondelsportbyeenkomste.
d. Landloop.
e. Span- en individuele kompetisies.
f. Beoordeel, afset en tydhou.
g. Onderrig ten opsigte van al die vorms van atletiek, insluitende prak- tika.
h. Toutrek.

6. Bajonetskerm

a. Die uitvoering van lesprogramme vir rekrute.

b. Reëls van die Royal Tournament.

c. Beoordeel, optree as skeidsregter, e.d.m.

d. Die organisasie van byeenkomste. 
7. Stoei
a. Tegnieke van stoei in die Cumberland-styl.
b. Vervaardiging en improvisering van die nodige uitrusting.
c. Die organisasie van byeenkomste.

8. Gimnastiek
a. Behendigheid (tuimel).
b. Brug.
c. Rekstok.
d. Springkas.
e. Beoordeling van toetse en kompetisies.

9. Swem
a. Landdril en bybringing van drenkelinge.
b. Reddingswem.
c. Swem.

10. Joe-Jitsoe
a. Die waarde daarvan.
b. Die praktiese toepassing.

11. Noodhulp

a. Onderrig in die leerplan van die St. John's Ambulance.
b. Eksamen ter verkryging van die sertifikaat van die St. John's Ambu- lance.

12. Aangeebal
a. Voorbereidende praktika.
b. Praktika.
c. Optrede as skeidsregter.
d. Die waarde van aangeebal in die ontwikkeling van die karakter.

13. Dissipline
a. Praktiese toepassing, netheid van voorkoms en sindelikheid.
b. Die waarde en betekenis van dissipline.
c. Dinamiese dissipline.

14. Bykomende Onderwerpe

Indiese knuppels, figuurmarsjeer, hoë perd, stoelvertoning, stokdril en massage.

\section{Lesings en Demonstrasies (Liggaamlike Opleiding)}

1. Uiteensetting van die leerplan.

2. Die doel en omvang van liggaamlike opleiding.

3. Beginsels van liggaamlike opleiding.

4. Die kuns om onderrig in liggaamlike opleiding te gee.

5. Die geskiedenis van liggaamlike opleiding.

6. Saamstel van lesprogramme.

7. Byhou van aantekeningboeke.

8. Demonstrasies met betrekking tot liggaamlike opleiding.

\section{Rekreatief}

9. Demonstrasie van boksreëls, optrede as skeidsregter, beoordelaar, e.d.m.

10. Demonstrasie en lesings met betrekking tot spanatletiek-byeenkomste.

11. Die organisasie van atletiek- en landloopbyeenkomste.

12. Die organisasie van bokstoernooie.

13. Die organisasie van vlagkompetisies binne 'n eenheid. 


\section{Medies}

14. Die oorsprong van die lewe.

15. Die struktuur van die weefsels.

16. Die skelet.

17. Die spiere van die liggaam.

18. Die senuweestelsel.

19. Die spysverteringstelsel.

20. Die sirkulatoriese stelsel.

21. Die asemhalingstelsel.

22. Die uitskeidingstelsel.

23. Teorie met betrekking tot massage.

24. Algemene aantekeninge i.v.m. opleiding bv. dieet, drankmisbruik, gevare van alkohol, e.d.m.

\subsubsection{Sertifikate}

Net soos in die geval van kursusse 18G en 19G wat in 1923-24 deur maj. Wand-Tetley aangebied was, is sertifikate aan die einde van die kursus aan suksesvolle kandidate uitgereik.

Die verdeling van die sertifkate in dele 1,2 en 3 was basies dieselfde as dié wat aan die einde van maj. Wand-Tetley se kursusse uitgereik is, behalwe ten opsigte van die volgende:

Deel 3.

Deel 2: Skerm is vervang deur bajonetskerm en atletiek is verskuif na

Deel 3: Roei en massage asook die herstel en instandhouding van speelvelde is uit dié deel weggelaat, terwyl atletiek bygevoeg is.

Hierdie wysigings het egter geen noemenswaardige voordeel ten opsigte van die gehalte van instrukteur wat opgelei is, beteken nie.

\subsubsection{Eksamens, Toetse en Puntetoekenning}

1. Tegniek - (posisie, uitvoering en vaardigheid). Eksamens en toetse is gebaseer op werk wat gedurende die kursus gedoen is, asook op individuele en spankompetisies met betrekking tot oefeninge wat gedurende die kursus gedoen is $-35 \%$.

2. Leierskap - (persoonlikheid en klashantering) - 45\%.

3. Teorie - beoordeling van werk wat gedurende die kursus gedoen is, kennis van liggaamlike opleiding, anatomie, fisiologie en onderwerpe wat onder die hoof ,tegniek" uitgevoer is $-20 \%$.

\subsubsection{Kwalifikasies vir die verskillende grade van die Sertifikaat}

Die klassifikasie van studente op grond van puntetoekenning in een van die drie dele of grade van die sertifikaat is dieselfde as dié wat in die leerplan van kursusse $18 \mathrm{G}$ en 19G, wat deur maj. Wand-Tetley in 1923-24 aangebied is, neergelê was.

Boks

Die volgende fasette van boks is tydens die kursus behandel:

\section{Beoordeling}

1. Eerste fase: Tel van skoon treffers op en vanaf die teiken.

2. Tweede fase: Beoordeling van skoon treffers, gedeeltelik beskermende en onbeskermende houe.

3. Derde fase: Beoordeling van stadige gevegte tussen instrukteurs.

4. Vierde fase: Beoordeling van gevegte tussen kursusgangers. 
Optrede as Boksskeidsregter

1. Eerste fase: Demonstrasie, oefen en verduideliking van foute.

2. Tweede fase: Demonstreer van korrekte manier van optree as skeidsregter en beoordelaar.

3. Derde fase: Beheer oor beginners in boks en die vel van beslissings.

4. Vierde fase: Beheer oor gevegte tussen ervare boksers; die onderskeid tussen nie-opsetlike en opsetlike foute.

5. Vyfde fase: Beheer oor gevegte tussen beginners in samewerking met aankondiger en tydhouers.

\section{Teorie en Organisasie van Bokstoernooie}

1. Eerste lesing:
a. Samestelling van 'n komitee.
b. Bepaling van datums.
c. Advertensies.
d. Propaganda.
e. Beamptes.
f. Inskrywings.
g. Instruksies aan deelnemers.
h. Sitplekreëlings.
i. Uitrusting benodig.
j. Verblyf en etes van boksers.
k. Verkoop van kaartjies.
1. Orkes.

2. Tweede Lesing: Voor die toernooi:

i. Voorbereidings vir ontvangs van deelnemers en beamptes.

ii. Mediese ondersoeke, inweeg van boksers en loting.

iii. Pligte van punte-optekenaar.

iv. Loslootjies.

Gedurende die toernooi:

v. Bepaling van die aantal gevegte en die duur van die toernooi.

vi. Pligte van die aankondiger.

vii. Reëlings vir toeskouers.

viii. Beheer oor toeskouers.

ix. Reëls i.v.m. rook:

$\mathrm{x}$. Bedwelmende drank.

xi. Geldpryse.

xii. Toekenning van punte.

Na die toernooi:

xiii. Nasien en versorging van uitrusting.

xiv. Bedankingsbriewe.

xv. Finansiële state.

\section{Praktiese Organisasie.}

1. Bepaling van die tyd nodig vir 'n toernooi, volgorde van gevegte, byhou van rekords, e.d.m.

2. Die oprigting van 'n bokskryt en die tref van die nodige reëlings vir die toernooi. 


\section{Atletiek:}

Die volgende onderwerpe m.b.t. die metode en tegnieke van baan- en veldnommers was in die leergang ingesluit:

1. Baannommers.

a. Voorafgaande baanwerk, houding, e.d.m.

b. Wegspring en naellope.

c. Eindpoging in naellope.

b. Middel- en langafstandwedlope.

e. Aflosse.

f. Baantaktiek.

g. Naellope.

h. Hekkies.

i. Beoordeling van baan- en veldnommers.

\section{Veldnommers.}
a. Paalspring.
b. Hoogspring.
c. Gewigstoot.
d. Hamergooi.
e. Spiesgooi.
f. Verspring.

\section{Landloop.}

4. Toutrek.

5. Praktika.

a. Die uitlê van 'n 440 tree-baan.

b. Die voorsiening van hoog- en verspringbakke.

c. Voorbereiding van 'n atletiekbaan vir 'n byeenkoms by naellope, eindpunte, hoog- en verspringstaanders, merk van gewigstoot, hamergooi, spiesgooi en werpskyfgebiede.

d. Praktika in die uitvoering van die pligte verbonde aan optrede as skeidsregter, hoofbaan- en assistent-baanbeamptes sowel as die hoofveld- en assistent veldbeoordelaars, tydhouers, afsetter, e.d.m.

e. Instandhouding van sportterreine.

f. Die merk van sportterreine.

g. Toutrek.

Beoordeling van Bajonetskermgevegte: fases bestaan:

Hierdie onderwerp is ' $n$ toevoeging tot die leerplan en het uit die volgende

1. Eerste fase:

a. Opsporing van goeie treffers op die teiken, aanlê, e.d.m.

b. Opsporing van treffers op en vanaf die teiken wat nie voldoende is vir die doeleindes van puntetelling nie, maar wel voldoende is om die geveg te beëindig.

2. Tweede fase:

Praktiese beoordeling van gevegte tussen leerlinge en die bepaling van die geldigheid van treffers.

Optrede as skeidsregters gedurende Bajonetskermgevegte:

Eerste fase: Demonstrasie van die pligte van die skeidsregter, beoordelaar, e.d.m.

Tweede fase: Opsomming van 'n fase (die reg om aan te val, dubbel treffers, reg om terug te staan, die vraagstuk van tyd en afstand). 
Derae fase: Upureae as skeidsregter, die sienswyses van beoordelaars, die opsom van fases, e.d.m.

Vierde fase: Praktiese spangevegte, kompetisies tussen eenhede en poelgevegte. Swemtoetse. 1924 voorkom.

Die swemtoetse toon presies ooreenkoms met die wat in die leerplan van

Atletiektoetse:

Dit het die volgende atletiekitems en puntetoekenning behels:

\begin{tabular}{|c|c|c|c|c|c|c|c|}
\hline Toets & $38 \%$ & $40 \%$ & $45 \%$ & $50 \%$ & $55 \%$ & $60 \%$ & $65 \%$ \\
\hline Hoogspring & $3.7^{\prime \prime}$ & 3'8'" & 3'10', & 4' & 4'1" & 4'2"' & $4^{\prime} 4^{\prime \prime}$ \\
\hline Paalspring & 7.2” & 7'4"' & 7'6"' & 7'8"' & $7 ' 10^{\prime \prime}$ & 8 ' & $83^{\prime \prime}$ \\
\hline Verspring & $16^{\prime}$ & 6’3"' & $16^{\prime} 6^{\prime \prime}$ & $16 ’ 9 "$ & $17^{\prime}$ & $17 ’ 6 ”$ & $179^{\prime \prime}$ \\
\hline Gewigstoot & $26^{\prime}$ & $26^{\prime} 6^{\prime \prime}$ & 27 & 27'6"' & $28^{\prime}$ & $28^{\prime} 6^{\prime \prime}$ & $29^{\prime}$ \\
\hline Spiesgooi & $90^{\prime}$ & 92' & 94' & $96^{\prime}$ & $98^{\prime}$ & $100^{\prime}$ & 105 \\
\hline Werpskyf & $55^{\prime}$ & $60^{\prime}$ & $65^{\prime}$ & $70^{\prime}$ & $75^{\prime}$ & $80^{\prime}$ & $85^{\prime}$ \\
\hline Hamergooi & $55^{\prime}$ & $60^{\prime}$ & $65^{\prime}$ & $70^{\prime}$ & $75^{\prime}$ & $80^{\prime}$ & $85^{\prime}$ \\
\hline \multirow[t]{2}{*}{$1 \mathrm{Myl}$} & $7 \mathrm{~min}$ & $6 \mathrm{~min}$ & $6 \mathrm{~min}$ & $6 \mathrm{~min}$ & $6 \mathrm{~min}$ & $6 \mathrm{~min}$ & $5 \mathrm{~min}$ \\
\hline & 10 sek & 55 sek & 40 sek & 25 sek & 15 sek & & 50 sek \\
\hline $3 \mathrm{Myl}$ & $26 \mathrm{~min}$ & $25 \mathrm{~min}$ & $24 \mathrm{~min}$ & $23 \mathrm{~min}$ & $22 \mathrm{~min}$ & $21 \mathrm{~min}$ & $20 \mathrm{~min}$ \\
\hline 100 Tree & $133 / 5$ & $132 / 5$ & - & $131 / 5$ & - & 13 & $124 / 5$ \\
\hline Toets & $70 \%$ & $75 \%$ & $80 \%$ & $85 \%$ & $90 \%$ & $95 \%$ & $100 \%$ \\
\hline Hoogspring & 4'6"' & 4'7'" & 4'8', & 4'10"' & 5 , & - & $5 ' 2 ”$ \\
\hline Paalspring & 8'6"' & 8'9" & 9' & 9’3"' & 9'6"' & 9'10"' & $10 ' 8 "$ \\
\hline Verspring & $18^{\prime}$ & $18^{\prime} 6^{\prime \prime}$ & 18’9"' & 19’6"' & $20^{\prime}$ & $20 ' 6 "$ & 21 \\
\hline Gewigstoot & 29'6"' & $30^{\prime}$ & $31^{\prime}$ & $32 '$ & $33^{\prime}$ & $34^{\prime}$ & 35 , \\
\hline Spiesgooi & $110^{\prime}$ & $115^{\prime}$ & $120^{\prime}$ & $125^{\prime}$ & $130^{\prime}$ & $135^{\prime}$ & $140^{\prime}$ \\
\hline Werpskyf & $90^{\prime}$ & $95^{\prime}$ & $100^{\prime}$ & $103^{\prime}$ & $104^{\prime}$ & $107^{\prime}$ & $110^{\prime}$ \\
\hline Hamergooi & $90^{\prime}$ & $95^{\prime}$ & $100^{\prime}$ & $105^{\prime}$ & $110^{\prime}$ & $115^{\prime}$ & $120^{\prime}$ \\
\hline \multirow[t]{2}{*}{$1 \mathrm{Myl}$} & $5 \mathrm{~min}$ & $5 \mathrm{~min}$ & $5 \mathrm{~min}$ & $5 \mathrm{~min}$ & $4 \mathrm{~min}$ & - & $4 \mathrm{~min}$ \\
\hline & $30 \mathrm{sek}$ & 25 sek & 15 sek & 5 sek & $55 \mathrm{sek}$ & & 45 sek \\
\hline $3 \mathrm{Myl}$ & $19 \min$ & $18 \frac{1}{2} \mathrm{~min}$ & $18 \mathrm{~min}$ & $17 \mathrm{~min}$ & $16 \frac{1}{2} \mathrm{~min}$ & - & $16 \mathrm{~min}$ \\
\hline 100 Tree & $123 / 5$ & & 12 & $114 / 5$ & $113 / 5$ & - & $112 / 5$ \\
\hline
\end{tabular}

Kursusgangers moes die volgende persentasies in die individuele nommers behaal om as standaard, tweede klas, eerste klas of as spesiaal gegradeer te word:

\begin{tabular}{|c|c|c|c|c|c|}
\hline Standaard & $\cdots$ & $\ldots .$. & & & $40 \%$ \\
\hline Tweede klas & … & ........ & … & $\ldots$ & $60 \%$ \\
\hline Eerste klas ...... & 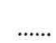 & w. & . & … & $80^{\circ}$ \\
\hline Spesiaal & ....... & . & . & $\ldots \ldots$ & $100 \%$ \\
\hline
\end{tabular}

Om studente in die verskillende kategorieë van die sertifikaat te klassifiseer, is die gemiddelde van die individuele nommers gebruik. Die volgende maatstaf is voorgeskrywe:

\begin{tabular}{|c|c|c|c|c|}
\hline Standaard ....... & $\cdots \cdots$ & 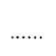 & & \\
\hline Tweede klas & r... & $\cdots$ & $\cdots$ & $\ldots$ \\
\hline Eerste klas & $\ldots . .$. & N. & … & \\
\hline Spesiaal & ....... & ....... & . & $\ldots \ldots$. \\
\hline
\end{tabular}

Omdat hierdie maatstaf weens die veranderde, hedendaagse norm nie meer van toepassing is nie kan 'n vergelyking nie getref word nie. 


\section{Gimnastiektoetse:}

Met uitsondering van enkele gimnastiekbewegings is die toetse in alle opsigte dieselfde as dié wat deur maj. Wand-Tetley in 1923-24 vir kursusse aan die S.A. Militêre Skool opgestel is.

Bewyse is ook gevind dat hierdie toetse dieselfde is as dié wat destyds in die Britse leër in gebruik was. Dit beteken dat die Britse invloed, ook in hierdie opsig sowel in die liggaamlike opleiding van die Unie-Verdedigingsmag as in die S.A. Polisie Opleidingskollege, deurgedring en posgevat het en as 'n vasgestelde norm aanvaar is.

\subsubsection{Enkele opmerkings betreffende die leerplan}

Soos reeds aangedui is, bestaan daar 'n merkwaardige ooreenkoms tussen die leerplan van maj. Wand-Tetley wat in 1923-24 opgestel was vir kursusse $18 \mathrm{G}$ en $19 \mathrm{G}$ wat aan die S.A. Militêre Skool gehou is en die leerplan van hierdie kursus wat bykans 10 jaar later by die S.A. Polisie Opleidingsdepot aangebied is.

Algemeen gesproke was die leergang van die S.A. Polisie Opleidingsdepot omvattend en het dit voorsiening gemaak vir lesings oor die beginsels van liggaamlike opleiding, die doel en omvang daarvan asook aangaande die geskiedenis van dié vak.

Alhoewel die teoretiese gedeelte slegs $20 \%$ van die totale persentasie was, beteken die insluiting van bogenoemde vakke noodwendig 'n positiewe verdieping en verbreding van die student se agtergrondkennis van liggaamlike opleiding.

Lesings met betrekking tot anatomie en fisiologie wat uitgebreider as vroeër, en die insluiting van euritmiek in die leerplan is verrassend.

Op grond van bogenoemde feite kan daar ook verklaar word dat die belangrikste onderwerpe met betrekking tot die hedendaagse studie van liggaamlike opleiding soos ons dit vandag verstaan in die kursus ingesluit is*.

\subsection{Sers. J. A. Wallis na Aldershot}

Daar sal onthou word dat lt.-kol. J. Mitchell-Baker reeds op 25 April 1922 in 'n skrywe aan kol. R. B. Campbell, D.S.O., Instrukteur van Liggaamlike Opleiding, Aldershot, sy begeerte uitgespreek het dat 'n geskikte offisier en onderoffisier van die Unie-Verdedigingsmag soontoe gestuur word om 'n volledige kursus in liggaamlike opleiding aldaar te volg.

Sedert 1924 is daar geen liggaamlike opleidingskursusse in die UnieVerdedigingsmag gereël nie, maar het 'n aantal militêre instrukteurs kursusse in liggaamlike opleiding aan die S.A. Polisie Opleidingsdepot oor die tydperk 19281934 gevolg.

Ongeveer 13 jaar nadat lt.-kol. Mitchell Baker, C.B., C.B.E., D.S.O., die gedagte m.b.t. die opleiding van liggaamlike opleidingspersoneel aan die Britse inrigting Aldershot, uitgespreek het, is op 21 Mei 1935 reëlings deur die SuidAfrikaanse Hoë Kommissaris in London met die Britse militêre outoriteite getref dat sers. J. A. Wallis, S.A. Staande Mag, die 48ste kursus vir Assistent Instrukteurs in liggaamlike opleiding te Aldershot kon bywoon. Hierdie kursus het vanaf 17 September tot 19 Desember 1935 geduur.

* Terwyl hierdie kursus nog in sy beplanningstadium was, het die Spesiale Dientbataljon (S.D.B.) en die Pionierbataljon hul wordingsjare as militêre eenhede binnegegaan. 
Sers. Wallis het op 12 Julie 1935 van Kaapstad vertrek om bogemelde kursus by die Britse Skool vir Liggaamlike Opleiding te Aldershot by te woon.

Op aanbeveling van die kommandant van laasgenoemde skool het sers. Wallis op 26 November 1935 aansoek gedoen om die 49ste Gevorderde kursus in Liggaamlike Opleiding vanaf 7 Januarie tot 9 April 1936 by genoemde inrigting by te woon.

Hierdie versoek is deur die militêre outoriteite in Pretoria goedgekeur.

Sers. Wallis was, sover vasgestel kon word, die eerste Suid-Afrikaner in militêre diens wat kursusse in liggaamlike opleiding aan hierdie Britse militêre inrigting gevolg het. Hy het, by sy terugkeer in 1936, die jongste ontwikkelings by die S.A. Militêre Kollege in die praktyk kom toepas.

Om in die behoefte aan opgeleide instrukteurs in die Unie-Verdedigingsmag te voorsien, is 'n kursus van 6 weke in Mei 1937 onder leiding van sers. J. A. Wallis aangebied wat deur een offisier en veertien onderoffisiere bygewoon is $(88: 98)$.

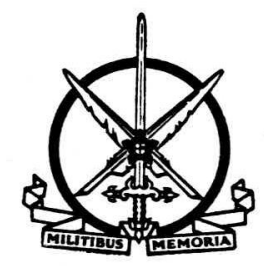

\section{Samevatting}

In die periode 1928-1936 is nie veel op die gebied van ligaamlike opleiding in die Unie-Verdedigingsmag vermag nie. Die opleiding van militêre instrukteurs in hierdie vak het aan die S.A. Polisieopleidingsdepot plaasgevind. Sers. J. A. Wallis het twee liggaamlike cpleidingskursusse in Engeland bygewoon. 


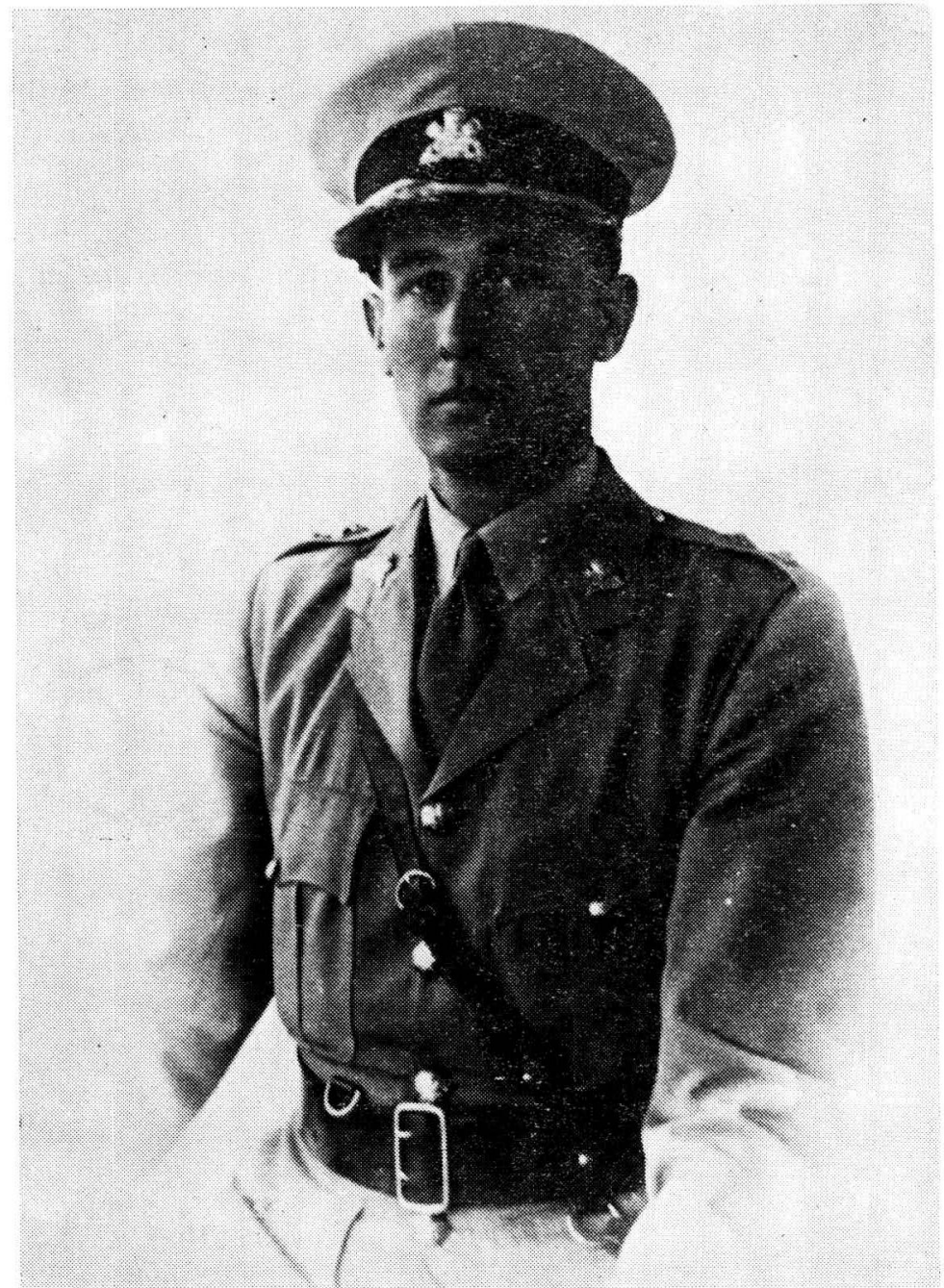

Luitenant-kolonel W. H. Evered Pool (later generaal-majoor, C.B., C.B.E., B.S.O.). Bevelvoerder Spesiale Diens Bataljon (S.D.B.): 1.2.1934. Kommandant Suid-Afrikaanse Militêre Kollege: 24.2.1938. Luitenant-kolonel: 1.9.1939.

Foto: M.H.A.D. 


\section{DIE SPESIALE DIENSBATALJON}

\subsection{Inleiding}

Die wêreldwye ekonomiese depressie wat kort na afloop van die Eerste Wêreldoorlog begin en tot in die dertiger jare voortgeduur het, het ook in die Unie van Suid-Afrika sy stempel op verskeie terreine afgedruk.

Een van die ernstigste vraagstukke wat die depressie vir die Staat meegebring het, was die sterk toenemende werkloosheid. Om hierdie probleem te bekamp, het die Staat tydelike maatreëls getref deur o.a., werk op paaie, spoorweë, besproeiingswerke en gesubsidieerde munisipale werke vir die werkloses te skep en te verskaf $(74: 181)$.

Hierdie metodes was egter onvoldoende om die abnormale werkloosheidsprobleem die hoof te bied, wat enersyds as gevolg van die reeds genoemde wêreldwye ekonomiese depressie voorgekom en andersyds deur die ernstige droogte, wat in die grootste gedeelte van die Unie in die somer van 1932-1933 voorgekom het, veroorsaak is. $(74: 180)$.

Die Departement van Arbeid het dit gevolglik nodig geag om die uitgawes m.b.t. die verligting van die werkloosheid grootliks te verhoog. Genoemde departement het o.m. sy subsidies aan verskeie plaaslike regeringsliggame uitgebrei om hulle op dié wyse in staat te stel om tydelike werkverskaffingsprojekte op spesiale ingestelde onderstandswerke te kan laat uitvoer $(75: 10)$.

Alhoewel dit in die eerste plek die verantwoordelikheid van die Departement van Arbeid was om die werkverskaffingsprobleem te bekamp, is die UnieVerdedigingsmag ook hierby betrek. Dit het tot die stigting van die Spesiale Diensbataljon (S.D.B.) in 1933 gelei, waaruit later die Junior Spesiale Diensbataljon (1939) en die Liggaamlike Opleidingsbataljon (1941) voortgevloei het.

\subsection{Samesprekings wat tot die ontstaan van die S.D.B. gelei het}

Die werkverskaffingsprogram van die Staat het 'n verreikende invloed op die Unie-Verdedigingsmag gehad. Dit word weerspieël in die feit dat 'n Staande Mag kadetkursus, d.i. 'n kwalifiseringskursus vir aanstelling as offisier in die Staande Mag, wat vir die einde van 1932 beplan was, 'n vroeër ongekende aantal aansoeke uitgelok het. Die keurkomitee, onder voorsitterskap van kol. sir Pierre van Ryneveld, kon van die duisende aansoeke slegs 30 aanvaar. Uit die aansoeke het geblyk dat 'n groot aantal jeugdiges klaarblyklik sonder vaste werk was.

Dit het tot gevolg gehad dat samesprekings tussen verskeie Staatsdepartemente begin het. Voorgestel is dat hierdie seuns aan 'n sekere soort militêre opleiding onderwerp moet word met die doel om die oorgangstydperk tussen skoolverlating en die moontlike datum van diensaanvaarding in die vorm van 'n geskikte militêre of siviele betrekking te oorbrug.

Die instelling van 'n eenheid vir dié doel is uiteindelik in 1932 aan die Departemente Verdediging en Arbeid oorgelaat met dié onderlinge verstandhouding dat die koste, verbonde aan die instelling van so 'n eenheid, tussen bogenoemde twee departemente verdeel sou word.

\subsection{Die totstandkoming van die S.D.B.}

Nadat besluit is om die instelling van die eenheid aan die Departement verdediging en Arbeid oor te laat, is vinnige vordering gemaak. Teen die einde van April 1933 het die werwing van 500 jeugdiges begin, terwyl tewens besluit is dat die eenheid as die Spesiale Diensbataljon (S.D.B.) bekend sal staan. 
Lt.-kol. G. E. Brink, D.S.O., is op 1 Mei 1933 as eerste bevelvoerder aangestel met maj. D. J. Roux as tweede-in-bevel. Ander offisiere: Kapt.(T/maj.) J. M. B. de Kock, kapt. B. S. van Wyk, kapt. H. B. Klopper, It. S. F. Strauss, It.(T/kapt.) T. S. Davies, It. P. J. Skead, 2/lt. J. P. A. Furstenberg.

Die eerste groep rekrute het hulle op 1 Mei 1933 aangemeld en na verdere samesprekings tussen die Departemente van Verdediging en Arbeid is besluit dat die aantal rekrute na 1000 verhoog word. Die uiteindelike sterkte van die S.D.B. het in Mei 1933 op 1966 te staan gekom. Teen die einde van Julie 1933 het die S.D.B. op volle sterkte gefunksioneer.

\subsubsection{Toelatingsvereistes}

Vanaf die stigting van die S.D.B. is opvoedkundige kwalifikasies en ouderdomme van die rekrute in aanmerking geneem om tot dié bataljon toegelaat te word. Die vereiste opvoedkundige kwalifikasie was st. 6 en die ouderdom tussen 17 en 21 . Van die eerste 2000 geslaagde aansoeke het die opvoedkundige kwalifikasies van st. 6 tot gegradueerdes gewissel.

Die mediese vereistes wat vir toelating neergelê is, was nie baie hoog nie. Die essensiële fiksheidsvereistes het neergekom op 'n gesonde hart en ledemate. Onder die rekrute was 'n aantal wat aan merkbare tekens van ondervoeding en onderontwikkeling gely het.

\subsubsection{Geaardheid van die Opleiding}

Die grondslag waarop die opleiding in die S.D.B. berus het, was liggaamlike opleiding en dril met die oog op die liggaamlike en morele opleiding van die rekruut. Die eenheid het daarna gestreef om 'n rekruut in die kortste moontlike periode tot so 'n mate te ontwikkel dat hy geskik sou wees om 'n ambag of beroep uit te oefen en dat hy ook liggaamlik en geestelik gesond sou wees.

Die stelsel van opleiding is só ontwerp dat vinnige liggaamlike ontwikkeling die resultaat was. Ten einde die strawwe liggaamlike opleiding en dril die hoof te bied, is die seuns goed versorg wat voeding en gesondheid betref.

Soos reeds vermeld, is liggaamlike opleiding as een van die belangrikste aspekte van die rekrute se opleiding in die S.D.B. beskou en danksy hul jeugdige ouderdom het hulle spoedig gunstig op hierdie soort opleiding reageer*. Gedurende die rekruut se opleiding moes hy een uur liggaamlike opleiding op vyf dae per week ontvang.

Alhoewel die eenheid vir 'n periode van 6 maande oor die dienste van slegs een gekwalifiseerde instrukteur in liggaamlike opleiding beskik het, is 'n hoë peil van fiksheid bereik. Twee instrukteurs is na afloop van die reeds genoemde liggaamlike opleidingskursus aan die S.A. Polisie Opleidingsdepot na hierdie eenheid oorgeplaas.

Abnormaal onderontwikkelde seuns is in spesiale klasse ingedeel waar daar op geskikte remediële oefeninge gekonsentreer is.

In die jaarverslag van die Bevelvoerder van die S.D.B. vir 1933-1934 is vermeld dat merkwaardige sukses met die toepassing van hierdie soort oefeninge behaal is.

Benewens liggaamlike opleiding het sport in die S.D.B. die nodige aandag geniet. Elke vertakking van sport is in die eenheid aangemoedig en lede was verplig om hieraan deel te neem. T.o.v. sportbeoefening was die eenheid goed 
toegerus. Daar is nie van lede verwag om hul eie sportuitrusting en klere te koop nie. Behalwe in die geval van truie is lede met betrekking tot die aankoop van sportklere gesubsideer. Die eenheid het die helfte van die onkoste gedra, terwyl die betrokke lid die ander helfte van die prys moes betaal.

\subsection{Openbare Optrede}

Die S.D.B. het veral in die beginjare op liggaamlike opleiding en dril gekonsentreer. Die eerste drilvertoning is reeds in Oktober 1933, slegs 4 maande na die stigting van die eenheid, op die Wanderers-terrein in Johannesburg deur 500 lede aangebied.

In April 1934 is 'n besonder geslaagde militêre taptoe in Johannesburg by geleentheid van die Witwatersrandse Landboutentoonstelling gehou. Hierdie vertoning kan beskou word as die voorloper van 'n groot aantal vertonings op landboutentoonstellings dwarsdeur die Unie.

Ander vertonings wat gedurende die eerste jare van die S.D.B. se bestaan gehou is, was o.a. in die stadsaal van Pretoria op 1 September 1934 met 25 lede, op 22 September 1934 in samewerking met die orkes van die Imperial Light Horse in Johannesburg, en op 1 Oktober 1934 by die Wanderers-klub in Johannesburg tydens 'n byeenkoms van die Royal Scottish.

Deur middel van hierdie vertonings is die waarde van liggaamlike opleiding by die publiek tuisgebring. Dit het grootliks daartoe bygedra om die belangstelling in liggaamlike fiksheid dwarsdeur die land te bevorder en om nuwe lede vir die eenheid te werf.

Gedurende 5 jaar, d.w.s. van 1934-1939, is 10000 seuns tussen 17 en 21 jaar in die S.D.B. opgeneem van wie 9000 nuttige werkkringe gevind het.

Van hierdie aantal is 3400 in die Spoorwegdiens, 2500 in die S.A. Staande Mag, 1000 in die Polisie en Gevangenisdiens, 500 in die mynwese, 90 in die yster- en staalnywerheid, 320 in die Staatsdiens en 1200 in private werkkringe opgeneem $(32: 10)$.

\subsection{Reorganisasie}

Op 16 September 1939 is die bestaande S.D.B. op 'n drie bataljon-grondslag gereorganiseer om die Spesiale Diensbrigade te vorm, terwyl die maksimumouderdomsgrens na 25 jaar verhoog is. Dit het tot gevolg gehad dat die S.D.B. van 'n jeugorganisasie tot 'n volwaardige militêre eenheid, bestaande uit volwassenes waarvan die lede later 'n puik oorlogsrekord sou behaal, uitgegroei het.

\subsection{Die Junior Spesiale Diensbataljon (Junior-S.D.B.)}

Soos reeds vermeld, was een van die toelatingsvereistes vir jeugdiges in die S.D.B. dat hulle die ouderdom van 17 jaar moes bereik het. Dit was 'n leemte in die S.D.B. in sy ou vorm en om dit te oorbrug is die Junior Spesiale Dientbataljon (Junior-S.D.B.) op 10 November 1939 as 'n sub-eenheid van die Spesiale Diensbrigade gestig.

\subsubsection{Doel}

Die doel met die stigting van die Junior-S.D.B. was om die gaping, wat tussen skoolverlating en aansluiting by die eintlike S.D.B. ontstaan het, te oorbrug en om op die wyse moontlike morele en sedelike verswakking en disintegrasie te voorkom. 


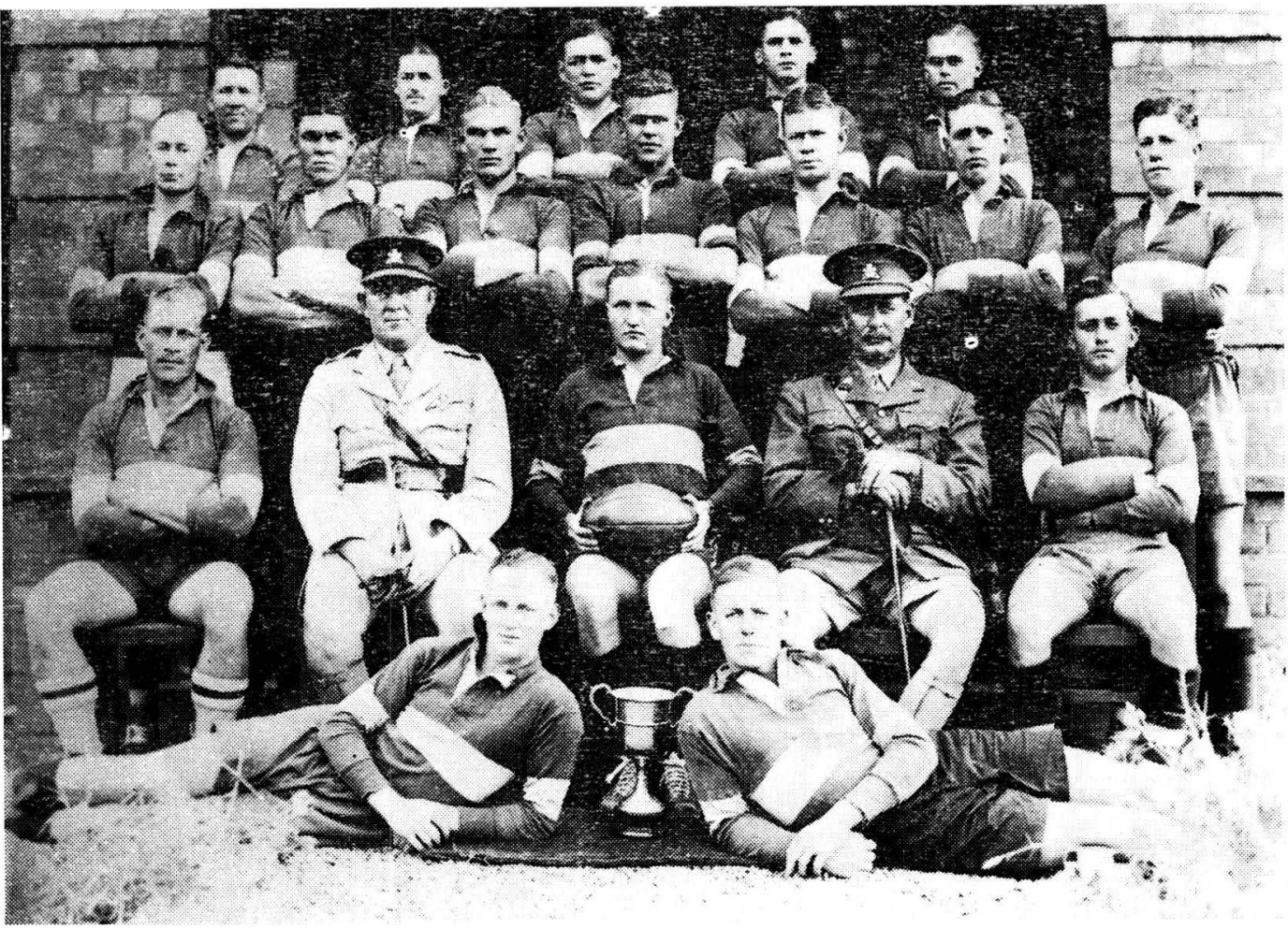

(van links na regs): Agterste Ry

Tweede Ry:

Sittende

Leёnde:
Kpl. B. Koen, Kpl. J. Wessels, W.Kpl. S. du Plessis, M'skap J. Lingenfelder, M'skap L. Stander.

W.Kpl. O. van Deventer, W.Kpt. L. Dreyer, W.Sjt. K. Potgieter, W.Kpl. D. van der Merwe, Kpl. McLennon, M'skap J. Kriek, W.Kpl. J. Strydom.

Sjt. J. Coetser, Lt.-kol. H. Klopper, M'skap S. van der Merwe, (Kapt.), 2 Lt. C. Brits, W.Sjt. R. Jardine.

M'skap H. Gericke en W.Sjt. A. Lynn.

Foto en Onderskrif: R. S. Watson/S.A.L.M. 


\subsubsection{Opleiding}

Die opleiding van die Junior-S.D.B. was daarop gemik om lede voor te berei om in die senior-bataljons opgeneem te word sodra hulle die ouderdom van 17 jaar bereik.

Elke lid moes minstens een periode per dag onderrig in liggaamlike opleiding ontvang. Noukeurige aantekeninge met betrekking tot die aantal onderrigperiodes en die vordering wat elkeen daarin maak, moes gehou word. Dit is gedoen met die doel om die aard van die opleiding, wat lede by oorplasing na die senior-bataljons moet ontvang, te bepaal.

'n Gemiddelde van minstens vier periodes per week vir die duur van die lid se diens by die Junior-S.D.B. is vir liggaamsoefeninge afgesonder. Afwesigheid as gevolg van wagdiens en ander verpligtinge is ook in aanmerking geneem.

\subsubsection{Die Ontstaan van die K-Pelotons}

Seuns wat by die S.D.B. wou aansluit, moes medies geskik wees. Dit het spoedig duidelik geword dat baie van die medies geskikte seuns op 16 jarige ouderdom, nadat hulle aan die skoolverpligtinge voldoen het, by die S.D.B. wou aansluit. Om vir hierdie seuns voorsiening te maak is die Junior-S.D.B. in die lewe geroep.

Daar het egter nie 'n inrigting bestaan wat medies ongeskikte seuns kon huisves en oplei nie. Die Departement van Volkwelsyn het besef dat die meeste van hierdie seuns 'n las vir die Staat sou word indien hulle nie vroegtydig behandeling sou ontvang nie.

Ten einde 'n klein aantal van die medies ongeskikte mannekrag vir die arbeidsmark toe te rus, het die Departement van Volkswelsyn besluit om R210 per jaar per persoon vir twee jaar hieraan te bestee.

'n Proefneming is in 1938 van stapel gestuur toe die departemente van Volkswelsyn, Verdediging, Arbeid en Gesondheid besluit het om 'n sekere aantal medies ongeskikte seuns by die Junior-S.D.B. te voeg met die doel om hulle liggaamlik geskik vir die arbeidsmark te maak. Hierdie seuns is in die K-Pelotons (vernoem na die toenmalige Sekretaris van Volkswelsyn, mnr. Kuschke) ingedeel.

Die skema is op 14 Februarie 1940 in die lewe geroep en het bestaan uit twee pelotons van 50 lede elk. Die pelotons is in die gebied van die S.D.B. op Voortrekkerhoogte gehuisves. Die bevelvoerder van laasgenoemde eenheid was verantwoordelik vir die organisasie en militêre opleiding van die pelotons, terwyl die instrukteurs van die Tak Liggaamlike Opleiding van die S.A. Militêre Kollege, in oorleg met die Direkteur-generaal van Mediese Dienste, verantwoordelik vir die remediële opleiding was.

Die opleiding het bestaan uit oefeninge wat deur die offisier-geneeskundige van die Tak Liggaamlike Opleiding van die S.A. Militêre Kollege voorgeskryf is asook uit ander militêre opleiding waarvoor hy die persoon geskik mag ag. Alle lesings wat vir die lede van die Junior-S.D.B. voorgeskryf is, is ook aan hierdie seuns aangebied. Die lesings het oor esprit de corps, gedrag buite kasernes, persoonlike higiëne, e.d.m. gehandel.

\subsection{Die Liggaamlike Opleidingsbataljon (L.O.B.)}

Die ondervinding het getoon dat daar 'n groot behoefte vir die voorsiening van remediële opleiding vir 'n groot aantal liggaamlike ongeskikte jong mans wat moontlik in die Unie-Verdedigingsmag opgeneem kon word, bestaan 
het, maar wat as gevolg van hul liggaamlike gebreke daartoe verhinder is. Om uitvoering aan hierdie bykomstige behoeftes te gee, is besluit om die K-pelotons te vergroot tot 'n bataljon, 'n besluit wat in November 1940 goedgekeur is.

Lt.-kol. J. C. Barnard is met ingang van 1 Januarie 1941 as die eerste bevelvoerder aangestel.

Die destydse Minister van Verdediging, adv. Oswald Pirow, het die naam Liggaamlike Opleidingsbataljon aan die nuutgestigte eenheid toegeken.

\subsubsection{Organisasie}

Die L.O.B. is, hoofsaaklik volgens ouderdomme van lede, in vier kompanies ingedeel.

1. 'n Aanvangskompanie.

2. 'n Kompanie vir die ouderdomsgroep van 15 tot 17 jaar.

3. 'n Kompanie vir die ouderdomsgroep van 18 tot 24 jaar.

4. 'n Kompanie vir die ouderdomsgroep van 25 tot 35 jaar.

Elke kompanie is weer in pelotons onderverdeel waar die verdeling op die volgende mediese fiksheidspeil berus het:

1. Diegene wat byna fiks is.

2. Dié wat semi-fiks is.

3. Dié wat onder die mediese fiksheidspeil is.

Vir opvoedkundige doeleindes het die lede in die ouderdomsgroep 15 tot 17 jaar 'n algemene skoolopleiding asook sulke vakopleiding as wat nodig geag is, ontvang. Die keuse van skoolopleiding het by die lede in die ouderdomsgroep van 18 tot 24 jaar berus, terwyl diegene in die ouderdomsgroep van 25 tot 35 jaar gespesialiseerde opleiding sou ontvang.

Hierdie groepering is só ontwerp dat algemene militêre opleiding, liggaamlike opleiding, bestuur van die eenheid in die algemeen asook die nodige heilgimnastiek oor die algemeen maklik uitgevoer kon word.

Voorsiening is, benewens vir die vereiste militêre personeel, ook vir die volgende vakkundige personeel op die diensstaat van die L.O.B. gemaak: 'n Offisier-geneeskundige, 'n psigiater, 'n gesondheidsoffisier, assistente en 'n vakkundige.

Die sielkundige en psigiater moes met mekaar saamwerk in gevalle waar hul werksaamhede oorvleuel.

\subsubsection{Werwing}

Die Departement van Openbare Gesondheid, Maatskaplike Welvaart en en Arbeid moes in samewerking met die Direkteur-generaal Geneeskundige Dienste en die Direkteur van Werwing van die Unie-Verdedigingsmag reëlings vir die werwing van rekrute vir die nuutgestigte eenheid tref. Alle applikante moes voor geneeskundige distriksrade verskyn om genoemde rade in staat te stel om verslag te doen oor die geskiktheid van die applikante vir verdere militêre diens nadat hulle die nodige chirurgiese of genesende behandeling ontvang het.

\subsubsection{Indeling i.v.m. Gebreke}

Seuns is by hulle aankoms in die ontvangsgroep opgeneem. Daar is hulle deur die mediese offisier ondersoek om te bepaal of hul mediese of tandheelkundige behandeling nodig het. Terselfdertyd het die sielkundige ook IK-toetse afgeneem om te bepaal in watter skool elkeen geplaas moet word of watter soort ambag hulle moet volg. 
In die ontvangsgroep is ' $\mathrm{n}$ seun ook ingelig t.o.v. die werksaamhede van die eenheid en van die nodige klerasie en uitrusting voorsien.

Seuns in die ontvangsgroep is volgens die behandeling wat hulle moes ondergaan in die volgende groepe verdeel:

1. Die platvoetgroep, vir seuns met platvoete en beenmoeilikhede, wat deur middel van oefeninge of mediese behandeling genees kan word.

2. Die O-groep, vir seuns wat onderontwikkeld, ondergewig en ondervoed was en wat ook vertraagde puberteits- en na-operatiewe gevalle ingesluit het.

3. Dic ruggraatgroep, vir alle gebreke aan die ruggraat of enige rompafwykings, soos kuikenbors e.d.m.

Verder is die L.O.B. in 1942 in A- en B-kompanies of groepe verdeel en ' $n$ lid is nie toegelaat om van een kompanie of groep na 'n ander te gaan nie voordat hy nie bewys gelewer het dat sy herindeling geregverdig is nie. Dieselfde verdeling as hierbo het in genoemde kompanies bestaan.

Die laaste stap voordat ' $n$ lid die eenheid verlaat het, was om na die gevorderde groep te gaan - 'n ideaal wat elke seun nagestreef het.

\subsubsection{Opleiding in die L.O.B.}

\section{Militêre Opleiding}

In die L.O.B. het die seuns en jong manne nie net met liggaamlike en remediële opleiding te make gehad nie. Hulle het ook militêre opleiding ondergaan met die doel om dissipline aan te kweek. Hierdie soort opleiding het egter nie wapenopleiding ingesluit nie, maar was beperk tot dril, staande bevele, dissıpline, higiëne, e.d.m.

\subsubsection{Liggaamlike en Remediële Opleiding}

Die liggaamlike fiksheidspeil van die lede van die L.O.B. is verhoog deur die toepassing van gegradeerde liggaamsoefeninge. Tesame met liggaamsoefeninge het 'n behoorlik gebalanseerde dieet en mediese behandeling daartoe bygedra dat lede van die eenheid 'n hoë fiksheidspeil gehandhaaf het. Seuns wat siek gevoel het, moes die dokter spreek wat hulle dan onder observasie gehou of, indien nodig, na die hospitaal gestuur het. Dit was ook een van die mediese offisier se take om dieete vir die seuns uit te werk.

Bykomend tot die gegradeerde liggaamsoefeninge het seuns ook remediële of mediese oefeninge ontvang wat spesifiek vir dié soort siekte of afwyking ontwerp was. In hierdie opsig was dit ook die verantwoordelikheid van die mediese offisier om te bepaal watter soort remediële oefening vir 'n bepaalde afwyking nodig was. Indien die behandeling massering vereis het, is die seun vir behandeling na die L.O.B. se masseur gestuur.

Spesiale eksperimente m.b.t. die vermeerdering in gewig, lengte, IK e.d.m. is ook uitgevoer en die resultate is met dié van ander skoolpligtiges vergelyk. Die fotograaf wat aan die personeel van die L.O.B. verbonde was, het foto's geneem wat later vir vergelykingsdoeleindes gebruik is.

In 1944 het die personeel van die L.O.B., belas met remediële opleiding, uit twee offisiere, een adjudant-offisier en 20 instrukteurs bestaan. Sommige van die senior personeellede het oor die volgende kwalifikasies beskik: (a) 'n Assistentkursus in Liggaamlike Opleiding, (b) 'n Gevorderde kursus in Liggaamlike Opleiding en (c) 'n Remediële kursus. 
Ten einde die leser 'n beeld te gee van die opleiding wat 'n instrukteur in remediële opleiding moes ondergaan, word die leerplanne van bogenoemde kursusse hier kortliks aangedui:

1. Die Assistent-kursus in Liggaamlike Opleiding

a. Leierskap.

b. Organisasie van spele.

c. Teorie van Liggaamlike Opleiding.

d. Elementêre anatomie en fisiologie.

e. Die teorie en praktiese toepassing van boks.

f. Die teorie en praktika van atletiek.

g. Die teorie en praktika van swem.

h. Die teorie en praktika van stoei volgens die Bacon-styl.

i. Praktiese uitvoering van behendigheid, spronge, oefeninge op die rekstok, brug, vrystaande oefeninge, groter en kleiner spele en hindernisopleiding.

j. Noodhulp.

2. Die gevorderde kursus in Liggaamlike opleiding

Die leerplan het dieselfde vakke as die Assistent-kursus in Liggaamlike Opleiding ingesluit, maar 'n baie hoër peil en tegniek in die uitvoering van die praktika is vereis.

\section{Die instrukteurskursus in Remediële Opleiding}

Hierdie kursus, wat twee maande geduur het, was hoogs gespesialiseerd van aard.

Die leerplan het die volgende behels:

a. Besondere anatomie van die voet, die onderbeen, die dy, die spiere van die romp, maag-, rug- en skouerspiere, die groter spiere van die bo-arm, en die voorarm, die hand- en borsspiere wat met die skouer en bo-arm verbind is.

b. Toegepaste anatomie ten opsigte van bogenoemde spiere.

c. Behandeling van pes planus, hallux valgus, metatarsalgia, genu valgum, torticollis, kyphosis, lordosis, scoliosis en behandeling van na-operatiewe gevalle.

d. Fisiologie van die spyskanale, die hart-bloedvatstelsel en die geslagsurinestelsel

e. Leierskap.

f. Swem.

g. Genesende spele.

h. Noodhulp.

i. Die organisasie van spele.

Hierdie leerplan toon aan dat die werk van gespesialiseerde aard was en dat ' $n$ instrukteur wel deeglik opgelei moes word om sy taak behoorlik te kon uitvoer.

\subsubsection{Werksaamhede van die Instrukteur}

Soos vermeld, was die remediële instrukteur 'n spesialis wat 'n deeglike kennis van die teorie en praktiese toepassing van anatomie moes besit.

Die organisasie van die gimnasium by die L.O.B. was só ingestel dat alle doserende remediële personeel daagliks lesings oor ingewikkelde anatomiese onderwerpe ontvang het. Op hierdie lesings het lesings oor die senuwee- en bloedvatstelsels gevolg wat deur die mediese offisiere van die L.O.B. en die twee offisiere van die Gimnasium aangebied is. 
Weekliks is lesings vir genoemde instrukteurs aan die Militêre Hospitaal, Voortrekkerhoogte, gereël waar spesialiste in verskeie inrigtings hul kennis geredelik aan die remediële personeel oorgedra het.

'n Vraelys is weekliks opgestel vir beantwoording deur die instrukteurs. Die punte wat hierin behaal is, is aangeteken om sodoende die vorderingspeil van die instrukteurs te bepaal. Aan die einde van elke kwartaal het die instrukteurs ook hul aantekeningboeke vir nasiendoeleindes ingehandig. Die punte wat hiervoor toegeken is, tesame met dié wat vir die weeklikse vraelys toegeken is, het bepaal of 'n gekose handboek oor anatomie aan die instrukteur as prys oorhandig sou word.

Hierbenewens het die remediële personeel een keer per kwartaal 'n besoek van een week aan die Mediese Skool in Johannesburg gebring waar lesings in anatomie en fisiologie deur professore van genoemde inrigting aangebied is.

\subsubsection{Oorsig oor die gebreke wat behandel is}

Watter gebreke is deur middel van remediële oefeninge herstel?

Daar is bevind dat ongeveer $75 \%$ van die lede wat in die L.O.B. opgeneem is aan een van drie grade van platvoete gely het. Die klassifikasie van platvoete in grade is gebruik om die graad van die gebrek aan te dui.

Dit het die volgende behels: veroorsaak.

a. Posturale platvoete - Dié primêre gebrek het 'n neiging tot platvoete

b. Platvoete van die eerste graad - In hierdie geval is die spiere en ligamente wat die voetboog in posisie hou, verswak.

c. Platvoete van die tweede graad - Spiere en ligamenie wat die voetboog in posisie hou, is aangetas.

d. Platvoete van die derde graad, t.w. dié wat ontstaan het as gevolg van 'n verdraaiing van die beenstruktuur, kon nie deur middel van remediële oefeninge herstel word nie en is gevolglik nie vir behandeling in die L.O.B. ingesluit nie.

Die behandeling van platvoete het die volgende behels:

1. Skoeisel. Skoene is opgebou, elke tree wat die pasiënt gedoen het, was 'n remediële oefening.

2. Beheer oor aktiwiteite. Lede wat aan platvoete gely het, is van parades, oormatig baie staan en algemene spele vrygestel. Vir hulle is spele gereël wat in 'n sittende posisie uitgevoer kon word.

3. Behandeling deur remediële oefening.

a. Nie-gewigdraende oefeninge. In hierdie groep is die oefening in die sittende of lêende posisie uitgevoer sodat die voete tydens oefeninge geen gewig dra nie.

b. Semi-gewigdraende oefening. Die remediële leerprogram is in 'n verhouding van twee nie-gewigdraende oefeninge tot een gewigdraende oefening verdeel.

c. Gewigdraende oefeninge. Namate die pasiënte van die een soort oefening na die ander gevorder het, het hulle oefeninge ontvang wat nie afbreuk gedoen het aan die resultate van die vorige oefening nie. Dic tospassing van gewigdraende oefeninge het die voet finaal vir normale leëropleiding voorberei. 
Ander gebreke wat algemeen voorgekom het, was die volgende:

1. Torticollis. Hierdie gebrek is aan die aantasting van die sternocleidomastoid-spiere toegeskryf. Die oorsaak kon aangebore of verworwe wees. Behandeling het deur middel van oefening geskied.

2. Kyphosis, m.a.w. 'n oordrewe buitewaartse verkromming van die borsgedeelte van die ruggraat wat 'n verlenging van die agterste ligamente en spiere van die rug met 'n ooreenstemmende verkorting van die voorste longitudinale ligamente van die ruggraat tot gevolg gehad het. Die behandeling deur middel van remediële oefeninge het 'n verkorting en versterking van die thorakale spiere van die ruggraat tot gevolg gehad.

3. Lordosis. By hierdie gebrek het 'n oordrewe binnewaartse verkromming van die lumbale gedeelte van die ruggraat voorgekom. Behandeling van hierdie gebrek, wat by ongeveer $90 \%$ van die seuns in die L.O.B. voorgekom het, het daarin bestaan dat die voorste buikspiere versterk is om die binnewaartse verkromming van die lumbale gedeelte van die ruggraat teen te werk.

4. Scoliosis. Hierdie verskynsel staan ook bekend as die sydelingse verkromming van die ruggraat en kan enkel-, dubbel- of drievoudig wees.

5. Na-operatiewe behandeling. Die remediële personeel van die L.O.B. het ook die geleentheid te baat geneem om na-operatiewe gevalle te behandel. Hierdie gevalle het senu-, amputasie- en hartgevalle ingesluit.

\subsubsection{Verstandelike Ontwikkeling}

\section{Die Generaal Brink-skool}

Dit was nie die doel van die LOB om slegs die liggaamlike fiksheidspeil van die jeug te verbeter nie. Daar is ook aandag aan die verstandelike ontwikkeling van sy lede geskenk.

Nadat reëlings in die wordingsjare van die L.O.B. met die Transvaalse Onderwysdepartement getref is, het seuns onder st. VII hul skoolopleiding aan die bestaande Generaal Brink-skool op Voortrekkerhoogte ontvang waar siviele onderwysers hulle onderrig het. As gevolg van onvoldoende fasiliteite kon seuns bo st. VII nie onderrig aan bogenoemde skool ontvang nie. Die L.O.B. was bygevolg genoodsaak om die nodige verstandelike onderrig aan hierdie groep met behulp van die Departement van Unie-Onderwys aan te bied. Voorkeur is egter aan opvoedkundig opgeleide leerkragte gegee om die personeel van die L.O.B. te vorm. Sodoende was die L.O.B. in staat om die nodige onderrig aan te bied. Eksamens is in samewerking met die Departement van Unie-Onderwys afgelê.

\section{Die Voortrekkerhoogte Junior-Hoërskool}

Vooruitgang op die gebied van verstandelike ontwikkeling is gemaak toe die Transvaalse Onderwysdepartement op 14 September 1942 die Voortrekkerhoogte Junior-hoërskool gestig het. Die personeel het bestaan uit 'n hoof en nege onderwysers - almal burgerlikes. By hierdie skool kon die seuns enige standerd vanaf st. V tot st. VIII volg en onderrig is deur middel van albei voertale aangebied. Genoemde skool het voorsiening vir 250 leerlinge gemaak.

Die belangrikheid van hierdie skool was daarin geleë dat liggaamsopvoeding as eksamenvak vir st. VII en VIII aangebied is $(38: 33)$.

* Prof Claude Smit, tans (1969) professor in Liggaamlike Opvoedkunde aan die Universiteit van Pretoria, is as eksaminator aangestel. 
Lesings oor liggaamlike opvoeding het in April 1943 'n aanvang geneem. Die kursus het uit 'n praktiese en teoretiese gedeelte bestaan wat elkeen 'n gelyke aantal punte van die totaal gevorm het. Eksaminatore is deur die Direkteur van Onderwys aangestel*. Hierdie aanstellings is in oorleg met die Bevelvoerder van die L.O.B. en die Komitee van Moderators van Transvaal gereël (59 : 34).

Aangesien hierdie inrigting, sover nagegaan kon word, die enigste skool in Transvaal was wat liggaamlike opvoeding as eksamenvak aangebied het, is dit wenslik om die leerplan volledig na te gaan.

Die Leerplan $(59$ : 35-37)

Die leerplan het teorie en praktika ingesluit.

1. Teorie

behels:

Die teoretiese gedeelte van die leerplan het lesings oor die volgende

a. Die geskiedenis van liggaamlike opvoeding, met die klem op liggaamsopvoeding in die oertydperke van die Sjinese, die Indiërs, die Perse, die Egiptenare, die Israeliete en die Bantoes. Dan het die seuns lesings ontvang oor die ligaamsopvoeding van die Grieke, Romeine, in die Middeleeue, gedurende die Renaissance en tydens die agtiende eeu. Lesings oor die verskillende metodes met betrekking tot liggaamlike opvoeding wat in die moderne tyd in Brittanje, Skandinawië, Duitsland, Nederland, die V.S.A. en Suid-Afrika gevolg is, is ingesluit.

b. Die Teorie van Liggaamsopvoeding.

(i) Deur middel van lesings is die begrippe liggaamstoertjies, -dril, -oefeninge, -opleiding, -opvoeding, gimnastiek, turn, sport, spel, ontspanning, vryetyd, ritmiese oefeninge, euritmiek en atletiek verduidelik.

(ii) Lesings m.b.t. die doel en die omvang van liggaamsopvoeding is onderverdeel in:

a. Die verband tussen liggaams- en geestesontwikkeling, soos uitgedruk in die klassieke gesegde Mens sana in corpore sano.

b. Algehele harmoniese ontwikkeling van die liggaam.

c. Sosiale verbetering deur liggaamsopvoeding.

3. Lesings oor aktiwiteite wat by liggaamsopvoeding ingesluit is en die waarde van elkeen van hulle. Dit behels:

a. Spele - ondergeskikte en hoofspan - en individuele span.

b. Atletiek - veld- en baannommers en spanatletiek-byeenkoms.

c. Gimnastiek.

d. Swem.

e. Dans.

f. Boks.

g. Stoei.

4. Lesings oor liggaamsontwikkeling en algemene kenmerke van die verskillende ouderdomsgroepe.

5. Lesings oor goeie houding, die waarde van die goeie houding en houdingsbewustheid is ook ingesluit.. 
6. M.b.t. oefeninge is lesings oor die volgende gegee:

Die waarde van oefeninge, geskiktheid, verswakking en moegheid, die gevare van ooroefening en slegte oefening, die waarde van voorbereidende en progressiewe oefening, voorsorgmaatreëls en die versorging van toerusting.

7. Verder is ook lesings oor die eienskappe van 'n goeie sportman en 'n goeie atleet gegee.

8. Die toepassing van fisiolagie in die liggaamsopvoeding het ingesluit:

(i) Die bewegingsapparaat. Gebreke as gevolg van slegte voeding, siekte, oorgewig, kleding en skoeisel, slegte houding en ongelukke.

(ii) Die uitwerking van oefening op die vel, die hart en bloedvate, die borskas en longe, die spysvertering en die koördinasie tussen die senustelsel en spiere.

(iii) Tewens is lesings oor die uitwerking van alkohol en nikotien op die stelsels en sisteme van die liggaam aangebied.

\section{Praktika}

Die werk in hierdie deel van die leerplan was gebaseer op Deel 1 van die Liggaamsopvoedingsleerplan vir seuns bo 10 en vir mans wat in 1943 deur die Nasionale Adviserende Raad vir Liggaamsopvoeding uitgegee is.

Dit het die volgende omvat:

a. Vrystaande oefeninge* met en sonder apparaat.

b. Apparaat-gimnastiek wat die rekstok, brug, steunspronge, klim en tuimel ingesluit het.

c. Atletiek is in hardloop, spring (hoog- en verspring) en gewigstoot onderverdeel.

d. Spele het uit ondergeskikte (binnenshuis- en opelug-spele) en georganiseerde spele bestaan.

e. Verskillende swemslae en reddingswem is prakties beoefen.

Aangesien die kursus nie in een jaar voltooi kon word nie, is daar in st. VII mee begin. Die tydsindeling was soos volg:

\section{Periodes van 40 minute}

Klas

St. VII

St. VIII

\section{Teorie}

2

3

Praktika
9
7

7
Totaal

Hierbenewens is $1 \frac{1}{2}$ uur per week aan studie van die vak gewy.

Die praktiese werk is deur die instrukteurs van die L.O.B. verrig.

\section{Eksamens}

In die eindeksamen is punte toegeken vir:

a. Die vrystaande oefeninge in ooreenstemming met die standaard van uitvoering wat bereik is.

b. Vir apparaatgimnastiek en atletiek is punte toegeken volgens tabelle wat vir hierdie doel ooreenkomstig die verskillende ouderdomsgroepe uitgewerk is**.

\footnotetext{
* Dit staan vandag bekend as vryoefeninge.
}

**Tabelle is saamgestel uit die Duitse werk: Richtlinien für die Leibeserzichung in Jugend" schulen. Weidmanche Verlagsbuchhandlung. Berlin, 1937. 
Individuele rapporte met betrekking tot spele is deur die Bevelvoerder L.O.B. uitgereik. In swem moes kandidate 'n toets aflê wat gelykgestaan het aan dié wat vir die bronsmedalje van die Koninklike Reddingswerkvereniging saamgestel is $(59: 35-37)$.

Hierdie kursus het 'n waardevolle agtergrond verskaf aan seuns wat by die Unie-Verdedigingsmag wou aansluit om as instrukteurs in liggaamlike opleiding opgelei te word.

\subsubsection{Vakonderrig}

Benewens die verstandelike ontwikkeling het die L.O.B. ook voorsiening vir die vakopleiding van seuns gemaak.

a. Die Tegniese Skool

Die Tegniese Skool is daargestel vir seuns wat begerig was om by die S.A. Lugmag aan te sluit of wat te oud was vir die gewone skool of wie se IK nie hoog genoeg was vir die hoërskoolopleiding nie. Seuns wat hul opleiding aan hierdie skool geniet het, kon ook st. VI, VII en VIII deur middel van die Departement van Unie-Onderwys aflê $(39: 34)$.

b. Die Telegraafskool

In hierdie skool is seuns voorberei vir diens in die seinkorps. Nadat hulle st. VIII geslaag het, het hulle 'n kursus van ses maande deurloop. Na suksesvolle voltooiing hiervan is hulle onmiddellik as lede van die Posdienspersoneel geregistreer $(39: 34)$.

Die personeel van die L.O.B. het nie die geestelike bearbeiding van die jeug verwaarioos nie, terwyl daar ook voorsiening vir die doeltreffende benutting van die jeug se vryetyd gemaak is $(39: 34)$. 


\section{Samevatting}

Die L.O.B., 'n uitvloeisel van die Spesiale Diensbataljon, het in sy bestaansjare as militêre instelling baie daartoe bygedra om nuttige burgers van individue te maak wat andersins hulle lewe lank gebuk sou gegaan het onder liggaamsgebreke en ander tekortkomings wat 'n stremmende uitwerking op hul persoonlikheid sou gehad het*.

Die sterkte van die L.O.B. het op 7 Mei 1941 slegs 84 rekrute getel, maar dit het gegroei en op 16 Augustus 1944 was daar nie minder as 1110 seuns in die eenheid wat opleiding ontvang het nie.

Die bestaan van die L.O.B. as militêre eenheid is op 1 April 1946 afgesluit toe dit sy werksaamhede as 'n burgerlike instelling onder die Departement van Unie-Onderwys naby Kimberley as die Liggaamlike Opvoedingsbrigade voortgesit het.

* 'n Meer gepaste naam sou o.i. Die Liggaamsopvoedingsbataljon gewees het.
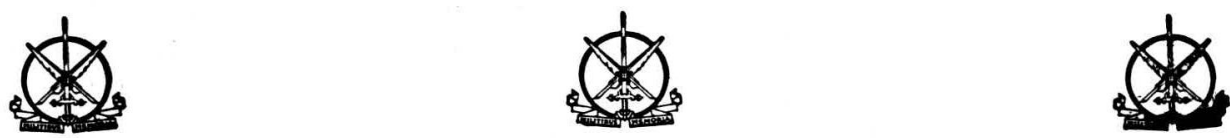


\section{DIE PERIODE 1937-1939}

\subsection{Inleiding}

Terwyl die Spesiale Diensbataljon sy werksaamhede op die gebied van liggaamlike opleiding voortgesit het, was daar 'n belangrike ontwikkeling op die gebied van liggaamlike opvoeding in die Unie van Suid-Afrika waarneembaar soos uit die volgende gegewens sal blyk.

\subsection{Agtergrondskets van die Nasionale Skema vir Liggaamlike Opvoeding}

Daar bestaan 'n ongedateerde memorandum, wat vermoedelik teen die einde van 1937 opgestel is, waarin die destydse Sekretaris van Verdediging aan die Minister van Verdediging meegedeel het dat die vak liggaamlike opvoeding verskeie besprekings uitgelok en openbare liggame in verskeie rigtings pogings aangewend het om die rigtings, wat deur die meeste beskaafde lande van die wêreld en veral Brittanje, Duitsland, die Verenigde State van Amerika, Denemarke en ander Skandinawiese lande op hierdie vakgebied daargestel het, na te gaan.

Die resultate wat genoemde lande behaal het om die liggaamlike fiksheidspeil van die jeug te verbeter en te handhaaf, is-aldus die memoraudum só opvallend en bevredigend dat ' $n$ algemene begeerte in die Unie van Suid-Afrika ontstaan het om soortgelyke doelstellings na te streef. Dit beteken egter nie dat liggaamlike opvoeding in die Unie geen aandag ontvang het nie. Inteendeel, liggaamlike opvoeding vorm reeds jare 'n deel van die opleidingsprogramme van die Spesiale Diensbataljon, die lede van die S.A. Spoorweë en Hawens, afdelings van die Aktiewe Burgermag en die S.A. Staande Mag, terwyl daar in skole, opleidingsen tegniese kolleges en by enkele universiteite 'n groeiende belangstelling ten opsigte van dié vak te bespeur is.

Voorts vermeld die Sekretaris van Verdediging dat daar ook verskeie sentra is wat in die behoeftes van sekere instansies van die algemene publiek voorsien. Hierbenewens het 'n groot aantal sport- en atletiekverenigings hul aktiwiteite in die Unie van Suid-Afrika voortgesit.

'n Ander belangrike opmerking wat ook in genoemde memorandum ge. maak is, is die feit dat daar baie jeugdiges, veral minderbevoorregtes, in die Unie was vir wie die geleentheid ontbreek het om gereelde en heilsame onderrig in liggaamlike opvoeding te ontvang, terwyl ander geen aandag aan hul liggaamlike welsyn bestee het nie.

Bogenoemde faktore het, aldus die memorandum, aanleiding gegee tot die gedagte dat 'n skema van liggaamlike opvoeding, wat in die behoeftes van alle instansies in die Unie voldoen, deur organisasies wat in hierdie vak belangstel asook deur sekere Staatsdepartemente bespreek behoort te word.

Hierdie gedagte is deur 'n komitee, wat op 27 April 1937 by Verdedigingshoofkwartier vergader het om die instelling van so 'n skema te bespreek, aanbeveel.

\subsubsection{Die Konferensie in Bloemfontein}

Die Sekretaris van Verdediging vermeld in genoemde memorandum ook dat 'n omvattende rapport deur die S.A. Olimpiese en Britse Spelevereniging saamgestel en in 1937 in Bloemfontein deur verteenwoordigers van verskeie organisasies, opvoedkundige liggame en sekere staatsdepartemente bespreek is. Daarna is 'n rapport wat oor die beoogde skema handel, tesame met 'n verslag van die Bloemfonteinse besprekings deur die hoofde van die Departement van Onderwys, Gesondheid en Verdediging aan die betrokke ministers gestuur. 
Hierdie departementele verslag het 'n aantal besonder bruikbare en konstruktiewe voorstelle betreffende 'n skema vir liggaamlike opvoeding op nasionale vlak bevat, maar die Ministers van Verdediging en Onderwys was van oordeel dat die koste verbonde aan die skema te hoog was. Gevolglik is genoemde rapport na die sekretarisse van die Departemente van Verdediging en Onderwys verwys met die opdrag dat 'n minder ambisieuse skema, wat meer betrekking op die gebruik van reeds bestaande fasilitieite vir liggaamlike opvoeding het, opgestel word.

Genoemde amptenare het die dienste van dr. G. v. W. Eybers, professionele raadgewer van die Departement van Onderwys, mnr. Kreft, Direkteur van Onderwys van Transvaal, en mnr. Forsyth, Onder-Sekretaris van die Departement Volkwelsyn, geko-opteer. Sekere breë beginsels, wat as 'n leidraad vir 'n doeltreffende nasionale skema van liggaamlike opvoeding teen minder onkoste kan dien, is aanvaar.

\subsubsection{Die Nasiunale Skema vir Liggaamlike Opvoeding}

Die nasionale skema vir liggaamlike opvoeding, soos deur bogenoemde komitee geformuleer en deur die kabinet in 1937 goedgekeur, sou veral in twee rigtings beweeg.

1. Deur die geriewe wat binne die bestek van die Departement van Onderwys, die Departement van Verdediging en die S.A. Spoorweë val, te verbeter en uit te bou.

2. Deur pogings aan te wend om geleenthede te skep om in die behoeftes van die algemene publiek, veral dié deel wat as gevolg van finansiële omstandighede op daardie tydstip nie hieroor beskik het om gereelde en volledige onderrig in gimnastiek te ontvang nie, te voldoen.

Die opstellers van die skema was van oordeel dat die volgende bedrae voldoende sou wees om in die onmiddellike behoeftes te voorsien en dat dit tergelykertyd ook as 'n basis vir toekomstige uitbreiding sou dien as dit nodig sou wees.

Uitgawes deur:

1. Die Departement van Onderwys - 115000 (R30 000).

2. Die Departement Verdediging, in samewerking met die Administrasie van die S.A. Spoorweë en Hawens - $£ 25000$ (R50 000).

3. Plaaslike regeringsliggame en vrywilliger-organisasies - $£ 10000$ (R20 000).

Die gedagte was dat, afgesien van die verpligte liggaamlike opleiding wat deur die Unie-Verdedigingsmag en die S.A. Polisie verskaf word, dit by alle ander instansies vrywillig moet wees. Deelname aan liggaamlike opleiding behoort egter vir sekere groepe persone in onderwysinrigtings verpligtend te wees. Hierdie groepe sluit in:

1. Alle skoolgaande kinders.

2. Vakleerlinge wat volgens wet verplig is om klasse te loop.

3. Student-onderwysers tydens hulle opleiding; met dien verstande dat die onderwysoutoriteite, onder wie die verskillende groepe val, van dié groep eis om aan liggaamlike opleiding deel te neem.

Die doeltreffende samewerking tussen die Departemente van Onderwys en Verdediging ten opsigte van die liggaamlike opvoeding van skoolkinders was van groot belang en het sorgvuldige aandag geniet. Die volgende beginsels is in 
1. Dit moet eerder die taak van die skooloutoriteite as van die kadetoffisiere wees om liggaamlike opvoeding aan die skoolgaande jeug te verskaf.

2. Die Departement van Verdediging behoort verantwoordelik te wees vir die opleiding, insluitende die liggaamlike opleiding, van die lede van die kadetbeweging.

3. Die liggaamlike opvoeding van leerlinge wat nie kadette is nie, bv. meisies en seuns wat buite die ouderdomsgrense van die kadette val, moet deur die skoolpersoneel, onafhanklik van of in samewerking met kadetoffisiere geskied.

4. Liggaamlike opvoeding moet deel van die skoolleerplan wees en gedurende skoolure aangebied word.

5. Kadetopleiding moet liggaamlike opleiding as 'n verpligte onderwerp insluit (alle militêre vakke sal egter opsioneel wees) en moet sover moontlik gedurende skoolure gegee word.

6. Daar moet noue samewerking tussen die Departemente van Verdediging en Onderwys met die opstelling van kursusleerplanne vir die opleiding van kadetoffisiere in liggaamlike opleiding bestaan.

7. Besondere aandag moet ook aan die opleiding van onderwysers op hierdie vakgebied bestee word. In hierdie verband moet voorsiening gemaak word vir die opleiding of die werf van deskundiges te Robertshoogte en aan die verskillende kolleges. Studentonderwysers sou tydens hulle opleiding in die geleentheid gestel word om, saam met hul algemene kursusse, die nodige opleiding in die beginsels en metodiek van liggaamlike opvoeding te ontvang en opgeleide onderwysers moet soortgelyke geleenthede gebied word. Dit bring mee dat die skole en ander inrigtings na verloop van tyd oor voldoende behoorlik gekwalifiseerde onderwysers op die gebied van liggaamlike opleiding sal beskik.

8. Om in die behoeftes van die algemene publiek, waarna reeds verwys is, te voorsien, behoort die daarstelling en skepping van geleenthede deur middel van die Aktiewe Burgermag, die vrywillige hulporganisasies, die St. John's Ambulance, die S.A. Spoorweë en Hawens, sport- en ontspanningsinrigtings vir liggaamlike opvoeding sowel as deur middel van deskundiges op hierdie gebied aangemoedig te word. Verder behoort plaaslike regeringsliggame gemagtig en aangemoedig te word om terreine en geboue, insluitende swembaddens, vir liggaamlike opvoedingsdoeleindes te verkry, in stand te hou of te verhuur, om onderwysers in diens te neem en om toelaes aan verenigings vir hierdie doel te betaal.

\subsubsection{Die Samestelling van 'n Adviserende Raad}

Die werksaamhede van die Nasionale Skema vir Liggaamlike Opvoeding moes geko-ördineer word. Met hierdie doel voor oë het die komitee wat die nasionale skema geformuleer het, aanbeveel dat 'n Nasionale Adviserende Raad vir Liggaamlike Opvoeding onder die Departement van Unie-Onderwys in die lewe geroep word. Die volgende instansies moet op hierdie Raad verteenwoordig wees:

1. Die Sekretaris van die Departement van Onderwys (voorsitter).

2-5. Een verteenwoordiger van elkeen van die provinsies, by voorkeur die hoof van die onderskeie Provinsiale Onderwysdepartemente.

6. Die Sekretaris van Verdediging.

7. Die Sekretaris van Volksgesondheid.

8. 'n Verteenwoordiger van die Departement van Volkswelsyn.

9. 'n Verteenwoordiger van die Verenigde Munisipale Uitvoerende Komitee. 
10. 'n Deskundige op die gebied van Liggaamlike Opvoeding verbonde aan die Departement van Unie-Onderwys, met sodanige ander deskundiges as wat die Adviserende Raad mag bepaal, in voeling sal bly ten einde die verskillende werksaamhede te ko-ördineer.

11. Een onderwyseres in liggaamlike opvoeding.

12. 'n Verteenwoordiger van vrywillige organisasies wat werk i.v.m. liggaamlike opvoeding verrig.

\subsubsection{Funksies van die Nasionale Adviserende Raad vir Liggaamlike Opvoeding}

Die funksies van hierdie Raad sou daarin bestaan om die Minister van Onderwys te adviseer in verband met:

1. Die dienste waarvoor fondse aan universiteite, inrigtings, tegniese kolleges, provinsiale administrasies, plaaslike regeringsliggame en vrywillige organisasies toegeken moet word.

2. Die opstel van kursusse en leerplanne in liggaamlike opvoeding en die ko-ördineer en standardisering van sodanige opleiding.

Die werksaamhede van die Nasionale Adviserende Raad vir Liggaamlike Opvoeding het op 16 Mei 1938, toe die eerste vergadering in Pretoria plaasgevind het, 'n aanvang geneem.

\subsection{Die Unie-Verdedigingsmag}

Intussen het die destydse Sekretaris van Verdediging op 24 Februarie 1937 voorstelle m.b.t. die aanwending van die masjinerie van die Departement van Verdediging vir die opleiding van seuns en jong mans in liggaamsoefeninge aan die Minister van Verdediging voorgelê.

\subsubsection{Die Voorstelle}

Genoemde voorstelle het die volgende behels:

1. Seksie 6 van die Verdedigingswet van 1913 het bepaal dat daar in stedelike en ander bewoonde gebiede waar behoorlike fasiliteite maklik verkry kon word dit van alle seuns tussen die ouderdomme van 13 en 17 jaar vereis kan word om 'n voorgeskrewe kursus van kadetopleiding te volg.

In terme van hierdie seksie kan 'n nuwe klas kadet, afsonderlik van die bestaande kadetorganisasie, geskep word. Die beoogde opleiding sou uit liggaamlike opleiding en eenvoudige dril bestaan. Op dié wyse kan alle seuns tussen die ouderdomme 13 en 17 jaar die beoogde opleiding gedurende skoolure ontvang.

2. Die onderrig kan deur onderwysers en/of reisende instrukteurs ter hand geneem word, aldus die Sekretaris van Verdediging.

3. Die Departement van Verdediging behoort broeke en gimnastiekskoene te verstrek. Groot opleidingskampe behoort minstens elke twee jaar gehou te word.

In genoemde voorstelle is ook vermeld dat die Direkteure van Onderwys van die provinsies gevra is om besonderhede t.o.v. liggaamlike opleiding, wat in daardie tyd in regeringskole in S.A. aangebied is, te verstrek. Kol. G. E. Brink, van die Unie-Verdedigingsmag, het opdrag ontvang om besonderhede t.o.v. die skema van liggaamlike opleiding, wat op dié tydstip in Engeland aangekondig is, asook besonderhede van die skema van liggaamlike opleiding wat in Duitsland in swang 
Verder het die Sekretaris voorgestel dat daar van alle toekomstige manlike kandidate vir aanstelling as onderwysers in skole vereis behoort te word om hulleself as instrukteurs in liggaamlike opvoeding te bekwaam. Van die onderwyspersoneel moet vereis word dat 'n goeie persentasie van hulle opleidingskursusse in liggaamlike opleiding volg. Indien nodig kan 'n jaarlike toelaag, bepaal op grond van die aantal seuns wat opleiding ondergaan, aan die onderwysers wat as instrukteurs aangewys word, betaal word.

Bykomend tot hulle kadetopleiding, sou daar ook van werklike kadette vereis word om aan klasse in liggaamlike opleiding deel te neem.

In die geval van jeugdiges tussen die ouderdomme van 17 tot 21 jaar, wat vir die vryetydse opleiding in die Aktiewe Burgermag moes registreer, het die Sekretaris van Verdediging geen probleme voorsien om aan hulle 'n program van liggaamlike opleiding voor te skryf nie. Hy het wel moeilikhede voorspel vir die instelling van enige stelsel wat op verpligte universele liggaamlike opleiding sou neerkom.

Voorts het die Sekretaris van Verdediging ook voorgestel dat reisende instrukteurs, t.w. van die beste gehalte in die Spesiale Diensbataljon, gekies word om kursusse in liggaamlike opleiding te volg sodat hulle as instrukteurs in groter sentra gestasioneer kord waar hulle onderrig kan gee asook toesig kan hou oor die onderrig wat op hierdie vakgebied aan skole gegee word. Gekwalifiseerde lede van die S.A. Polisie kan ook in dorpies aangewend word om liggaamlike opleidingsklasse te lei.

Hierdie voorstelle was daarop gemik om feitlik alle jong seuns en mans by 'n program van liggaamlike opleiding te betrek.

\subsubsection{Die Vergadering by Verdedigingshoofkwartier}

Op 27 April 1937 het 'n komitee, bestaande uit lt.-genl. A. J. Brink, D.T.D., V.D., D.S.O., Sekretaris van Verdediging, kol. Sir E. N. Thornton, K.B.E., V.D., Sekretaris van Openbare Gesondheid, en prof. M. C. Botha, Sekretaris van Unie-Onderwys, by Verdedigingshoofkwartier, Pretoria, byeengekom om die instelling van 'n stelsel van liggaamlike opvoeding in die Unie te bespreek.

Die komitee het die volgende besluite geneem:

1. Die instelling van 'n nasionale skema van liggaamlike opvoeding is in alle opsigte wenslik.

2. Die instelling van enige sodanige skema moet wye vertakkinge behels, waardeur verskeie staatsdepartemente en openbare liggame nou geraak sal word.

Genoemde komitee het, op grond van laasgenoemde besluit, aanbeveel dat 'n konferensie bestaande uit verteenwoordigers van die departemente Openbare Gesondheid, Onderwys, Welsyn en Verdediging, tesame met verteenwoordigers van die vyf universiteite, die Provinsiale Administrasies en die S.A. Olimpiese Vereniging, byeengeroep word om die instelling van 'n nasionale skema van liggaamlike opvoeding te bespreek. Die komitee was ook van mening dat subkomitees gevorm kan word om besonderhede aangaande die skema neer te lê.

Omdat staatsfondse noodwendig hierby betrokke sal wees, het die komitee verder aanbeveel dat die administrasie van liggaamlike opvoeding deur een staatsdepartement behartig behoort te word.

Die Minister van Verdediging het met hierdie voorstelle akkoord gegaan en aanbeveel dat die Departement van Onderwys moet voortgaan om die voorgestelde konferensie te belê. 
Verder het die minister bepaal dat die Departement van Verdediging sy spesifieke skema, m.b.t. die liggaamlike opleiding van seuns en jongmense wat aan kadetopleiding en diens in die Aktiewe Burgermag onderworpe was, in werking moet stel.

In hierdie verband verklaar die Sekretaris van Verdediging op 29 April 1937 in 'n skrywe aan die Hoof van die Generale Staf dat daar, a.g.v. 'n tekort aan gekwalifiseerde instrukteurs in liggaamlike opleiding in die Unie-Verdedigingsmag, probleme bestaan om enige skema van liggaamlike opleiding moontlik in werking te laat tree. Om dié probleem die hoof te bied, het hy die volgende voorgestel:

1. 'n Skool vir Liggaamlike Opleiding moet op Robertshoogte opgerig word. Die dienste van 'n offisier en 'n onderoffisier moet in Engeland verkry word vir 'n tydperk van 18 maande om die opleiding van instrukteurs in die UnieVerdedigingsmag te behartig.

2. 'n Geskikte offisier van die S.A. Staande Mag moet na die buiteland gestuur word om daar opleiding te ondergaan met die doel dat hy uiteindelik die bevel oor die beoogde skool sal oorneem.

\subsection{3. 'n Offisier van die Unie-Verdedigingsmag na die Buiteland}

Hierdie aanbevelings is verwesenlik. Op 7 Mei 1937 het die militêre owerhede van die Unie-Verdedigingsmag nominasies vir 'n geskikte offisier in die S.A. Staande Mag gevra om 'n kursus van 6 maande in liggaamlike opleiding in Engeland by te woon. Die keuse het op 2 de 1t. D. S. Pretorius geval wat vanaf 9 November 1937 tot 7 April 1938 'n kursus in liggaamlike opleiding aan die Army School of Physical Training te Aldershot bygewoon het.

Sover skrywer, aan die hand van plaaslike beskikbare argivale bronne, kan vasstel, was 2 de 1t. D. S. Pretorius die eerste offisier van die S.A. Staande Mag om 'n kursus in liggaamlike opleiding by bogenoemde Britse opleidingsinrigting te volg.

Hy het egter nie net 'n kursus in liggaamlike opleiding by Aldershot bygewoon nie. Op 24 November 1937 het lt.-kol. T. H. Wand-Tetley, O.B.E., van die Army School of Physical Training, Aldershot, voorgestel dat 2de 1t. Pretorius na afloop van sy kursusse besoeke aan Denemarke, Swede en Duitsland bring. Dit sou hom in staat stel om die stelsels en metodes wat in genoemde lande in swang was, na te gaan en te bestudeer.

Die goedgekeurde besoekprogram het die volgende behels:

1. Vanaf 14 Junie tot 12 Julie 1938 woon 2 de lt. Pretorius die groot Finse gimnastiekfees in Helsinki, gevolg deur die bywoning van 'n gimnastiekkamp by die Finse Instituut vir Atletiek in Vierumaki, by.

2. Daarna moet genoemde offisier Duitsland van 23 tot 29 Julie 1938 besoek waar hy die verskillende stelsels van liggaamlike en rekreatiewe opleiding in oënskou neem.

3. In Denemarke moet 2 de 1t. Pretorius van 31 Julie tot 14 Augustus 1938 'n kursus vin Niels Bukh se Gymnastic High School te Ollerup bywoon.

Aan die einde van 1938 het 2 de 1t. D. S. Pretorius na Suid-Afrika teruggekeer waar hy vanaf 1 Januarie 1939 as assistent offisier-instrukteur in liggaamlike opleiding aan die Tak Liggaamlike Opleiding van die S.A. Militêre Kollege aangestel is. By hierdie inrigting, waar instrukteurs in liggaamlike opleiding vir die Unie-Verdedigingsmag opgelei is, kon hy sy kennis wat hy tydens sy buitelandse kursusse en besoeke opgedoen het, met vrug aanwend. 


\subsubsection{Sekondering van 'n Britse Offisier en Onderoffisier na die Unie-Ver- dedigingsmag}

Terwyl reëlings getref is om 2de 1t. D. S. Pretorius na die buiteland te stuur om 'n kursus in liggaamlike opleiding in Engeland te volg, het die militêre outoriteite ook uitvoering gegee aan die reeds genoemde voorstel van die Sekretaris van Verdediging dat die dienste van Britse instrukteurs in liggaamlike opleiding verkry moet word om 'n Skool vir Liggaamlike Opleiding in die Unie-Verdedigingsmag te stig.

Die Sekretaris van Verdediging het hierdie reëlings, met behulp van die Hoë Kommissaris van die Unie van Suid-Afrika, op 7 Mei 1937 getref. Aanvanklik is gevra dat kapt. H. B. M. Croves, M.C., hierdie taak moes onderneem.

Die gevolg was dat kapt. F. S. S. Barlow, van die South Wales Borderers en kompanie-sers.-maj. G. Barber, Leicester Regiment, vanaf 31 Desember 1937 na die Unie-Verdedigingsmag gesekondeer is. Hulle het op 14 Januarie 1938 in Kaapstad aangekom en op 16 Januarie 1938 diens by die S.A. Militêre Kollege op Voortrekkerhoogte aanvaar.

Besonderhede ten opsigte van kwalifikasies in liggaamlike opvoeding kon, in die geval van kapt. Barlow, nie plaaslik opgespoor word nie, maar sers.maj. Barber het die volgende kursusse in Engeland gevolg: 'n Voorafgaande kursus in liggaamlike opleiding, 'n assistent-instrukteurskursus in liggaamlike opleiding, 'n gevorderde instruksiekursus in liggaamlike opleiding en 'n bywoningskursus in genoemde vak.

\subsubsection{Werksaamhede van kapt. Barlow en sers.-maj. Barber}

Kapt. Barlow het die toestand waarin liggaamlike opleiding op daardie stadium in die Unie-Verdedigingsmag verkeer het in oënskou geneem en sy bevindings op 21 Januarie 1938 skriftelik aan die kommandant van die S.A. Militêre Kollege voorgelê.

Volgens kapt. Barlow het daar geen definitiewe skema in liggaamlike opvoeding in die Unie-Verdedigingsmag bestaan nie en s.i. was 'n grootskaalse reorganisasie op hierdie gebied die enigste oplossing.

Hy het derhalwe voorgestel:

1. Die situasie moet hersien word en daar moet in die algemeen gesproke, op die doelstellings van 'n gesonde stelsel van liggaamlike opleiding vir 'n mag gelet word.

word.

2. Die bestaande toestand in die Unie-Verdedigingsmag moet hersien

3. Hy versoek om sy sienswyse met betrekking tot die metodes, waarop 'n doeltreffende en werkbare skema gebou kan word, te mag gee.

\subsubsection{Die Doelstellings van Liggaamlike Opleiding vir'n Leër}

Die doelstellings van liggaamlike opleiding vir 'n leër het volgens kapt. Barlow, onderstaande behels:

1. Om die individu liggaamlik en geestelik te ontwikkel en om maksimum liggaamlike doeltreffendheid te bevorder.

2. Om die karakter te ontwikkel.

3. Om liggaamlike gebreke by individue te herstel.

4. Om 'n individu tot so 'n mate te ontwikkel dat hy as 'n volwaardige en nuttige burger sy plek in die gemeenskap kan volstaan nadat hy die leër verlaat het. Dit was in wese die doelstellings van die Spesiale Diensbataljon. 


\subsubsection{Metode om die Doelstellings te Verwesenlik} verwesenlik.

Kapt. Barlow het twee maniere gesien om bogenoemde doelstellings te

Eerstens moet 'n liggaamlike opleidingskursus vir rekrute, om hulle harmonieus te ontwikkel en hulle toe te rus vir hul daaglikse taak, saamgestel word. Tweedens moet 'n stelsel van gereelde liggaamlike opleiding vir die opgeleide soldaat daargestel word waardeur die beoogde fisieke fiksheidsgeil gehandhaaf kan word.

Voorts het kapt. Barlow ook daarop gewys dat 'n onmetodiese of 'n niedoelgerigte stelsel van liggaamlike opleiding nooit bogenoemde doelstellings kan verwesenlik nie. Dit kan net so goed laat vaar word indien die instansies, wat hiermee gemoeid is, nie bereid is om hulleself al die moeite en onkoste wat hiermee gepaard gaan te getroos nie. Hierdie uitspraak het kapt. Barlow gebaseer op die toestand waarin hy liggaamlike opleiding in die Unie-Verdedigingsmag aangetref het.

\subsubsection{Kapt. Barlow se Bevindings}

Dic toestand waarin kapt. Barlow in 1938 liggaamlike opleiding in die Unie-Verdedigingsmag aangetref het, is deur hom in die volgende punte saamgevat:

1. Georganiseerde liggaamlike opleiding vorm nie 'n essensiële deel van dic opleiding van offisiere en onder-offisiere in enige vertakking van die UnieVerdedigingsmag nie.

2. Die Suid-Afrikaanse militêre outoriteite beskik weliswaar oor die dienste van slegs ' $n$ paar instrukteurs in liggaamlike opleiding, maar hulle is nie aan een sentrale vakopleidingsinrigting opgelei nie met dié gevolg dat die onderrig in liggaamlike opleiding, wanneer dit gegee word, aan stelselmatigheid mank gaan en s.i. geen doel dien nie.

3. Die afwesigheid van 'n sentrale skool in die Unie-Verdedigingsmag waar instrukteurs opgelei kan word, is 'n leemte.

4. By die verskillende kommandemente is geen gimnastieksale beskikbaar nie.

\subsubsection{Ooglopende Kenmerke van die Bestaande Toestand} die volgende:

Dic aanbeveling in kapt. Barlow se skrywe van 21 Januarie 1938 behels

1. Liggaamlike opleiding moet 'n definitief aanvaarde deel van die S.A. Staande Mag. Aktiewe Burgermag en Spesiale Diensbataljon se opleidingsprogramme word.

2. 'n Sentrale skool, vakkundig toegerus en van opgeleide personeel voorsien, moet op Robertshoogte tot stand gebring word om te verseker dat 'n konstante stroom van opgeleide instrukteurs na die verskillende eenhede van die Unie-Verdedigingsmag vloei.

3. Hierdie skool moet ook geleenthede vir eksperimentele studie en navorsing op die gebied van liggaamlike opleiding bied.

4. Kapt. Barlow het die sentrale skool, waarop die hele stelsel van liggaamlike opleiding vir die Unie-Verdedigingsmag sou rus, as die basis beskou en beklemtoon dat geen vordering op die gebied van liggaamlike opleiding gemaak kan word nie, voordat die beoogde skool nie gestig is nie. 
5. 'n Laaste opmerking van hom wat dat die hoofkwartiere van kommandemente, Aktiewe Burgermageenhede en die Spesiale Diensbataljon met die belangrikste liggaamlike opleidingsuitrusting toegerus moet word.

\subsubsection{Aanbevelings van kapt. Barlow}

Met die voorafgaande in gedagte het kapt. Barlow die volgende aanbevelings gedoen om die liggaamlike opleiding in die Unie-Verdedigingsmag op 'n georganiseerde en doeltreffende grondslag te plaas:

\section{Onmiddellike behoeftes}

Om die onmiddellike behoeftes te voorsien, moet die bestaande gimnasium en die aangrensende vliegloods op Robertshoogte opgeknap en van uitrusting voorsien word. Die volgende personeel moet aan die gimnasium toegevoeg word: Kapt. Barlow, sers.-maj. Barber, 'n mediese offisier wat deeltydse diens by die gimnasium verrig, ses of agt instrukteurs, gekies uit studente wat die eerste kursus gevolg het, 'n stoorman en 'n ordonnans.

\section{Kursusse}

Die eerste kursus wat 3 maande duur, moet deur 15 gekeurde onderoffisiere onder die ouderdom van 30 jaar en wat oor persoonlikheid, atletiekvermoë, onderrigvermoë en oor kennis van en ondervinding in liggaamlike opleiding beskik,, gevolg word.

Die tweede kursus van 60 offisiere en onderoffisiere van die Aktiewe Burgermag moet ook 3 maande duur. Die doel hiervan is om instrukteurs in liggaamlike opleiding vir die Aktiewe Burgermag op te lei.

\section{Liggaamlike Opleiding vir Rekrute en Opgeleide Soldate}

Laastens het kapt. Barlow aanbeveel dat alle rekrute van die S.A. Staande Mag, die Aktiewe Burgermag en die Spesiale Diensbataljon by aansluiting by genoemde instansies 'n kursus in liggaamlike opleiding moet volg. Die duur van hierdie kursus en die leerplan wat gevolg moet word, moet by omstandighede, eie aan elke rekruut, aangepas word.

Alle opgeleide lede van die S.A. Staande Mag, die Aktiewe Burgermag en die Spesiale Diensbataljon moet dwarsdeur die jaar aan gereelde klasse in liggaamlike opleiding deelneem. Ten slotte het kapt. Barlow aanbeveel dat 'n liggaamlike opleidingsinstrukteur van die S.A. Staande Mag na elke groep Aktiewe Burgermageenhede gesekondeer word om toesig oor die werk van Aktiewe Burgermaginstrukteurs in liggaamlike opleiding te hou.

Terwyl die aanbevelings van kapt. Barlow m.b.t. die stigting van 'n skool vir Liggaamlike Opleiding vir die Unie-Verdedigingsmag asook van die daarmee gepaardgaande voorstelle deur die militêre outoriteite oorweeg is, het hy en sy assistent, sers.-maj. Barber, hulle met die volgende take besig gehou.

Hulle het die onderrig in liggaamlike opleiding van kandidate wat 'n Staande Mag-instrukteurskursus bygewoon het, versorg. Terselfdertyd was hulle ook met liggaamlike opleiding aan die Spesiale Diensbataljon asook met die organisasie van vertonings wat genoemde eenheid in 1938 aan die Rand sou gee, behulpsaam.

Benewens hierdie take het hulle hulself ook voorberei vir die kursusse wat hulle in die Unie-Verdedigingsmag moet aanbied.

Ten slotte was hulle ook gemoeid met die reël van lesings en demonstrasies in liggaamlike opleiding te Robertshoogte, in die Oranje-Vrystaat, aan die Witwatersrand en in Natal. 
Die vertoning in Natal is op 15 Maart 1938 in Durban gehou. Die vertoonspan het uit 9 lede bestaan wat onder aanvoering van kapt. Barlow opgetree het. Die eerste helfte van die program is in beslag geneem deur die volgende burgerlike verenigings wat items van 10 minute elk gelewer het: Die Deutsche Turnverein, die Stan Dean Physical Training Academy, die League of Youth and Health, die Apollo Physical Training Club en die Central Gymnasium.

In die tweede helfte van die program het kapt. Barlow en sy span aan die beurt gekom. Die demonstrasie is deur 'n lesing van kapt. Barlow voorafgegaan.

'n Tipiese reaksie van die pers na afloop van hierdie vertoning was die volgende in die plaaslike Daily Tribune:

These men are well built and demonstrated with remarkable efficiency and speed the exercises which are being adapted as standard curriculum in the British Army (40).

Hierdic vertoning het tot gevolg gehad dat verskeie aansoeke deur die hoofkwartier van die Natalse Kommandement van burgerlike persone ontvang is wat begerig was om kursusse in liggaamlike opleiding aan die S.A. Militêre Kollege by te woon.

In hierdie verband het die Direkteur van Leëropleiding op 21 April 1938 geantwoord dat burgerlikes, wat begerig is om hul as instrukteurs in liggaamlike opleiding te bekwaam, by die S.A. Staande Mag deur middel van die Spesiale Diensbataljon moet aansluit. Hulle sou dan hul beurt, saam met ander, moet afwag om eers die Staande Mag kwalifiserende instrukteurskursus in liggaamlike opleiding kon volg. Die grondliggende gedagte van hierdie maatreël was dat alle lede van die Suid-Afrikaanse Instruksionele Korps ten alle tye vir algemene militêre sowel as vir instruksie in liggaamlike opleiding beskikbaar moet wees.

\subsubsection{Implementering van 'n Stelsel van Liggaamlike Opleiding in die Unie-}

\section{Verdedigingsmag}

Soos reeds vermeld het kapt. Barlow, wat op 23 Maart 1938 tot die tydelike rang van majoor bevorder is, daarop gewys dat daar geen georganiseerde stelsel van liggaamlike opleiding in die Unie-Verdedigingsmag bestaan het nie. Sy aanbevelings m.b.t. die opknapping van die bestaande gimnastieksale en die opleiding van instrukteurs het die nodige aandag van militêre owerheidsweë ontvang. Die gimnastieksale sou opgeknap en van uitrusting voorsien wees voordat die eerste kursus 'n aanvang neem.

Om voldoende instrukteurs in liggaamlike opleiding vir die Unie-Verdedigingsmag op te lei, is die volgende kursusse vir 1938 in die vooruitsig gestel:

1. Die eerste kursus in liggaamlike opleiding, vanaf 1 Mei 1938 tot 31 Julie 1938, vir gekeurde lede van die S.A. Instruksionele Korps wat moontlik goeie instrukteurs sou word.

2. Die tweede liggaamlike opleidingskursus van 15 Augustus 1938 tot 15 September 1938 vir 30 gekeurde kadetoffisiere benoem deur die Departement van Onderwys. Hierdie offisiere moes jonk wees, in goeie gesondheid verkeer en goeie sportmanne wees.

3. Die derde kursus is van 1 Oktober 1938 tot 15 Desember 1938 vir 30 instrukluurs van die S.A. Staande Mag gehou wat op daardie stadium met 'n algemene, kwalifiserende instrukteurskursus aan die S.A. Militêre Kollege besig was.

4. Die vierde en vyfde liggaamlike opleidingskursusse is vir 1939 in die vooruitsig gestel. 
Op 1 April 1938 is 'n bekende rugby-Springbok, D. H. Craven, met offisiersrang in die Unie-Verdedigingsmag as Organiseerder van Liggaamlike Opleiding aangestel.

\subsubsection{Skool vir Liggaamlike Opleiding}

Die beoogde skool vir Liggaamlike Opleiding het op 1 Mei 1938 werklikheid geword. Die skool sou nie as sodanig bekend staan nie, maar is as die Tak Liggaamlike Opleiding van die S.A. Militêre Kollege beskrywe.

In die komende jare sou hierdie Tak 'n belangrike rol in die opleiding van liggaamlike opleidingsinstrukteurs in die Unie-Verdedigingsmag speel.

\subsubsection{Kursusse aan die Tak Liggaamlike Opleiding van die S.A. Militêre Kol- lege 1938.}

Die eerste kursus, 414P, onder leiding van maj. Barlow en sers.-maj. Barber, het op 1 Mei 1938 'n aanvang geneem en tot 31 Augustus 1938 geduur. Sestien lede van die Unie-Verdedigingsmag het in hierdie kursus geslaag, terwyl sers. Wallis, was in 1936 'n kursus in liggaamlike opleiding in Engeland gevolg het, hierdie kursus as 'n opknappingskursus meegemaak het. Die volgende lede het o.a. in die kursus geslaag: Lt. (t/kapt.) D. H. Craven, 2de lt. C. L. de Jager, serse. W. E. Wocke, F. P. Smit, G. C. Bell, L. A. Carelson en kpl. H. C. Schmidt.

Aanvankliklik het 25 lede met hierdie kursus begin. Een offisier kon die kursus nie voltooi nie, twee onderoffisiere is medies ongeskik bevind en ses onderoffisiere is gedurende die kursus na hul tuiseenhede teruggestuur omdat hulle nie suksesvolle instrukteurs was nie. Hieruit kan afgelei word dat daar 'n mate van keuring ten opsigte van die instrukteurs voor die begin van die kursus gedoen is.

$\mathrm{Na}$ afsluiting van die kursus op 30 Augustus 1938 is 'n vertoning in lig. gaamlike opleiding deur deelnemers aan die kursus aangebied. Bo en behalwe aan militêre personeel is uitnodigings ook aan vooraanstaande lede van die publiek en die pers gerig om genoemde vertoning by te woon.

Die tweede kursus, 417P, het oor die tydperk 1 Oktober 1938 tot 31 Januarie 1939 gestrek. Doel van hierdie kursus was om alle lede van die S.A. Staande Mag, wat op daardie tydstip besig was met 'n kwalifiserende instrukteurskursus ook as instrukteurs in liggaamlike opleiding op te lei. Ander militêre instrukteurs kon ook vir hierdie kursus benoem word. Aan alle lede van die Robertshoogte- en Transvaalkommandement wat vir hierdie kursus aangewys is, sou 'n onderhoud deur maj. Barlow toegestaan word, terwyl hy lede in ander kommandemente op 5 September 1938 te woord sou staan.

Kandidate wat hierdie kursus wou volg, moes oor die volgende hoedanighede beskik:

1. Hulle moes 'n onderoffisiersrang vir ten minste 12 maande beklee het.

2. Nie ouer as 27 jaar wees nie -20 tot 24 jaar is as die beste ouderdomsgrens beskou.

3. Oor ondervinding as instrukteurs beskik.

4. Oor 'n junior-sertifikaat beskik.

5. Die kursus vrywillig bywoon.

6. 'n Atletiese tipe wees.

7. Lede van die S.A. Staande Mag wees. 
Die kursus het met 38 onderoffisiere begin van wie 34 die kursus voltooi het. Van hierdie aantal het 22 sertifikate ontvang, t.w. een le klas en $212 \mathrm{e}$ klas. Twaalf het gedruip. In 'n kursusrapport is vermeld dat die hoë druipsyfer direk toegeskryf kon word aan die feit dat $80 \%$ van die kandidate nie vooraf gekeur is nie, maar lede was van die S.A. Staande Mag-instrukteurskursus wat aangesê was om hierdie kursus by te woon. In laasgenoemde rapport is ook verklaar dat die ondervinding geleer het dat bevredigende resultate selde verkry is van studente wat verplig is om kursusse in liggaamlike opleiding by te woon. Hierbenewens werk dit ook stremmend in op die toegewyde student deurdat dit die vordering van die studente vertraag en die instrukteurs verhinder om hul tyd doeltreffend aan onderrig te bestee.

Die kursus is ook op 31 Januarie 1939 afgesluit met 'n vertoning in liggaamlike opleiding waaraan studente en instrukteurs van die Tak Liggaamlike Opleiding van die S.A. Militêre Kollege deelgeneem het.

\subsubsection{Liggaamlike Opleiding vir Kadetoffisiere}

Die opleiding van kadetoffisiere as instrukteurs in liggaamlike opleiding moet gesien word in die lig van ' $n$ beginsel wat in die Nasionale Skema vir Liggaamlike Opvoeding beliggaam is, nl. dat dit die verantwoordelikheid van die Departement van Verdediging is om die opleiding van kadetoffisiere, insluitende die liggaamlike opleiding van laasgenoemde offisiere, waar te neem.

Alhoewel 'n kursus vir die liggaamlike opleiding van kadetoffisiere reeds vir die tydperk 15 Augustus 1938 tot 15 September 1938 beplan was, het die Provinsiale Departemente van Onderwys dit onmoontlik gevind om kadetoffisiere tydens skoolkwartale vir hierdie doel van hul onderwysverpligting vry te stel.

Die eerste kursus van hierdie aard, 415P, is vanaf 3 Januarie 1939 tot 24 Januarie 1939 aan die Tak Liggaamlike Opleiding van die S.A. Militêre Kollege gereël.

Die leerplan wat gevolg is, het o.a. vir die volgende voorsiening gemaak:

1. Vier lesprogramme in liggaamlike opleiding wat geskik is vir skoolseuns.

2. Die elemente van klashantering.

3. Elementêre bokslesse.

4. Breinstimulerende spele.

5. Lesings i.v.m. bogenoemde onderwerpe.

In 'n verslag oor hierdie kursus is beklemtoon dat dit nie moontlik was om in drie weke meer aan die studente aan te bied nie as net 'n oppervlakkige kennis van die onderwerpe wat behandel is. Dit sou hulle in elk geval in staat stel om 'n daaglikse oefenperiode by hul betrokke skole waar te neem.

\subsubsection{Kapt. Craven na die Buiteland}

Nadat kapt. D. H. Craven die eerste kursus in liggaamlike opleiding aan die Tak Liggaamlike Opleiding van die S.A. Militêre Kollege op 31 Augustus 1938 voltooi het, het hy op 16 September 1938 na die buiteland vertrek waar hy 'n aantal kursusse bygewoon het. Hy het ook 'n aantal lande besoek met die doel om verskillende metodes, wat in daardie tyd in swang was, te bestudeer.

Uit korrespondensie blyk dat hierdie besoeke en vakstudie bedoel was om as 'n agtergrond te dien vir die daarstelling van 'n eie nasionale sisteem van ligaamsopvoeding waarby die nasionale karaktereienskappe van die volk in aanmerking geneem moet word. 
Weliswaar is in dié verband verwag dat so 'n strewe eers na jare met sukses bekroon sal word en teenstand sal ondervind, maar daar is - met die stuur van kapt. Craven - in elk geval 'n begin in dié rigting gemaak wat die eerste doelbewuste koersverandering t.o.v. die bestaande alleenheerskappy van die Britse stelsel in die Unie-Verdedigingsmag beteken het.

Kapt. Craven het van 13 Oktober 1938 tot 26 Februarie 1939 'n kursus in liggaamlike opleiding by die Reichsakademie für Leibesübungen te Berlyn bygewoon. Die leerplan wat gedurende hierdie kursus gevolg is, het o.m. die volgende ingesluit: Lesings oor onderwerpe soos fisiologie, anatomie, geskiedenis van liggaamlike opleiding, atletiek, voedingsleer, afrigting en metodiek. In die praktiese gedeelte is vir sport, spele, gimnastiek, vrystaande oefeninge en remediële opleiding voorsiening gemaak.

$\mathrm{Na}$ afloop van hierdie kursus het kapt. Craven tussen 8 Maart 1939 en 24 April 1939 'n aantal navorsingsbesoeke op die gebied van liggaamlike opleiding in Den Haag (26 Maart - 2 April 1939), Rome (4 - 9 April 1939), Parys en Journville (10 - 20 April 1939) en Brussel (20 - 24 April 1939) afgelê.

Hierna het hy na Engeland vertrek waar hy van 1 Mei 1939 tot 30 Junie 1939 'n kursus in liggaamlike opleiding aan die Army School of Physical Training te Aldershot bygewoon het.

$\mathrm{Na}$ voltooiing van hierdie kursus het hy ook 'n navorsingskursus te Loughborough, Engeland, vanaf 30 Junie 1939 tot 19 Julie 1939 gevolg. Hierna het hy die Lingiade in Stockholm, Swede, asook 'n gimnastiekkamp en twee kort kursusse in bogenoemde land bygewoon. Sy verblyf in Swede het vanaf 19 Julie 1939 tot 25 Augustus 1939 geduur.

Kapt. Craven is van Swede terug na Engeland. Op 27 Oktober 1939 het hy weer diens in die Unie-Verdedigingsmag aanvaar waar hy sy kennis en gedagtes op die gebied van liggaamlike opleiding kon toepas.

\subsubsection{Beplande Kursusse in Liggaamlike Opleiding gedurende 1939}

Nadat die grondslag vir die opleiding van instrukteurs in liggaamlike opleiding aan die Tak Liggaamlike Opleiding van die S.A. Militêre Kollege in 1938 en vroeg in 1939 deur maj. Barlow en sers.-maj. Barber gelê is, kon die personeel van die Tak Liggaamlike Opleiding met hierdie belangrike taak voortgaan. Maj. Barlow was nog steeds aan die hoof van dié inrigting.

gereël:

Die volgende kursusse is vir 1939 aan die Tak Liggaamlike Opleiding

1. Kursus 451P. Kwalifiserende kursus in Liggaamlike Opleiding (gevorderd) oor die tydperk 20 Februarie 1939 tot 20 Mei 1939. Die doel met hierdie kursus was om offisiere en instrukteurs van die S.A. Staande Mag,wat die vorige assistent-instrukteurskursus in liggaamlike opleiding suksesvol voltooi het, as toesighouers in dié vak op te lei. Die leerplan het o.a. die volgende vakke ingesluit: Liggaamlike opleiding, leierskap, organisasie, anatomie en fisiologie, boks, atletiek, swem en gimnastiek.

2. Kursus 452P. Kwalifiserende kursus vir Atletiekinstrukteurs van die S.A. Staande Mag en Aktiewe Burgermag. Hierdie kursus het vanaf 29 Mei 1939 tot 23 Junie 1939 geduur. Doel daarvan was om genoemde offisiere en onderoffisiere in die teorie en praktyk van atletiek te onderrig. Dit was nie die doel om militêre personeel in kampioene te ontwikkel nie, maar wel om hulle vertroud met atletiekafrigting te maak. 
3. Kursus 453P. Die tweede Liggaamlike Opleidingskursus vir kadetoffisiere het vanaf 10 Julie 1939 tot 29 Julie 1939 geduur. Die leerplan was dieselfde as dié wat vir die eerste liggaamlike opleidingskursus vir kadetoffisiere saamgestel is.

4. Kursus 455P. 'n Kort kursus in stoei. Hierdie kursus is vanaf 28 Augustus 1939 tot 2 September 1939 gehou en is met Staande Mag-stoeikampioenskappe afgesluit.

5. 'n Eksperimentele kursus in Liggaamlike Opleiding is ook vanaf 31 Julie 1939 tot 19 Augustus 1939 vir lede van die St. John's Ambulansbrigade vir 35 offisiere en onderoffisiere gereël.

6. Kursus 464P. Kursus in Heilgimnastiek, vanaf 14 Augustus 1939 tot 1 September 1939. Die mediese lesings is deur lt.-kol. P. Blair-Hook gegee, terwyl maj. Barlow en sers.-maj. Barber vir die lesings en praktika m.b.t. liggaamlike opleiding verantwoordelik was.

Die volgende onderwerpe is behandel:

1. Anatomie en Fisiologie. Lt.-kol. Blair-Hook skryf in 'n verslag oor hierdie kursus dat ' $n$ hoë standaard in genoemde vakke behaal is. Die peil was hoër as dié wat vir die goue medalje van die Rooikruis benodig word en ook hoër as dié wat hy gedurende 1937-1938 by die Army School of Physical Training, Aldershot, aangetref het. By die onderrig van hierdie twee vakke is van rolprente van die Departement van Onderwys gebruik gemaak en 1t.-kol. Blair-Hook het gevind dat dit tot voordeel vir die studente gestrek het. Dit het rolprente oor die hart, die bloed, die longe, die sirkulasie, die senustelsel en die spiere ingesluit.

2. Ander onderwerpe wat in die leerplan voorgekom het, was lesings oor: Eenvoudige sielkundige beginsels en patologie, voeding en dieet, eerstehulp, praktiese ondersoek van kandidate en die metode wat by die Recruits Physical Development Depot by Canterbury, Engeland, in gebruik was.

3. Die praktiese werk is in twee afdelings verdeel. Eerstens het dit uit bssprekings en praktiese beoefening van elke besondere individuele remediële oefening met spesiale aandag aan die anatomiese en remediële beginsels bestaan. Tweedens het dit die praktiese toepassing van remediële oefeninge op werklike gevalle behels. In hierdie verband het lt.-kol. Blair-Hook reëlings met die Spesiale Diensbataljon getref waardeur 50 lede wat aan verskeie gebreke gely het, beskikbaar gestel is. Hierdie gevalle is ondersoek, geklassifiseer en gegroepeer. Kandidate het daagliks, onder toesig van mediese en ander instrukteurs van die Tak Liggaamlike Opleiding, twee uur aan praktiese remediële oefeninge en algemene liggaamlike opleiding van die gevalle bestee.

4. Verder is die reeds vermelde funksies van die Nasionale Adviserende Raad vir Liggaamlike Opvoeding ook bespreek.

5. Handboeke wat tydens hierdie kursus in gebruik was, was die volgende:

Anatomy and Physiology of Physical Training (Galloway), Manual of Physical Training 1931 en die St. John's Manual of Ist Aid to the Injured.

7. Kursus 457P. Liggaamlike Opleidingskursus vir offisiere en onderoffisiere van die Aktiewe Burgermag vanaf 2 Oktober 1939 tot 20 Oktober 1939. Die doel met hierdie kursus was om genoemde lede van die Aktiewe Burgermag as leiers op hierdie vakgebied in Burgermageenhede op te lei. 
8. Kursus 460P. Kwalifiserende kursus vir assistent-instrukteurs in Liggaamlike Opleiding van 15 November 1939 tot 15 Maart 1940. Die leerplan het o.m. die volgende onderwerpe ingesluit: Liggaamlike opleidingslesprogramme vir rekrute en opgeleide soldate, gimnastiek, boks, atletiek, swem, anatomie, fisiologie en die teorie van liggaamlike opleiding.

Intussen het die Tweede Wêreldoorlog in September 1939 uitgebreek. Later sou dit tot drastiese veranderinge in die liggaamlike opleidingsprogramme van die Unie-Verdedigingsmag lei.

Kapt. D. H. Craven is ook tydens sy afwesigheid met buitelandse kursusse as Organiseerder van Liggaamlike Opleiding in die Unie-Verdedigingsmag met standplaas by Verdedigingshoofkwartier ingedeel. Hierdie aanstelling het vanaf 23 November 1939 van krag geword.

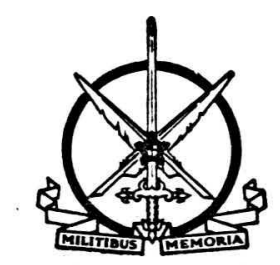

Samevatting

Die grondslag vir die opleiding van militêre instrukteurs in die Unie van Suid-Afrika is in die jare 1938 tot 1939 gelê deur die sekondering van twee Britse militêre instrukteurs na die Unie-Verdedigingsmag en die bywoning van buitelandse kursusse in liggaamlike opleiding deur twee offisiere van die Staande Mag nl. It. D. S. Pretorius en kapt. D. H. Craven.

Enersyds het dit tot gevolg gehad dat die Britse sienwyse t.o.v. liggaamlike opleiding sy wortels dieper in die militêre kringe in Suid-Afrika geskiet het. Andersyds het dit daartoe bygedra om hierdie vakgebied positief in Suid-Afrika, en veral in die Unie-Verdedigingsmag, uit te bou.
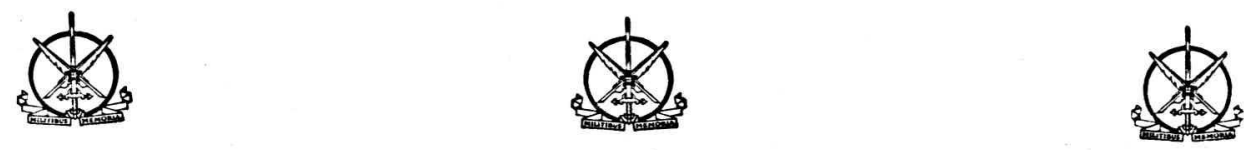


\section{LIGGAAMLIKE OPLEIDING IN DIE UNIE-VERDEDIGINGSMAG GEDURENDE DIE EERSTE HELFTE VAN DIE TWEEDE WERELDOORLOG}

\subsection{Inleiding}

Voor die uitbreek van die Tweede Wêreldoorlog, in September 1939, het die klem op die gebied van liggaamlike opleiding in die Unie-Verdedigingsmag op die opleiding van instrukteurs geval. Ook nadat die Unie in dieselfde maand tot die stryd toegetree het, is bogenoemde werk- en denkwyse in die Unie-Verdedigingsmag voortgesit.

\subsection{Dienstermyn van Britse Militêre Instrukteurs in Suid-Afrika verleng}

Terwyl die opleiding van militêre instrukteurs in liggaamlike opleiding in die Unie-Verdedigingsmag voortgegaan het, is op 9 Desember 1939 reëlings met die Britse Leër getref dat die dienstermyn van maj. F. S. Barlow tot 28 Februarie 1940 en dié van sers-maj. G. Barber tot 30 Junie 1940 verleng word. Hierdie reëlings was nodig omdat liggaamlike opleiding in die Unie-Verdedigingsmag nie voor 1 Julie 1940 op 'n behoorlik georganiseerde grondslag geplaas sou wees nie, aldus die Sekretaris van Verdediging.

Die reëlings ten opsigte van maj. Barlow, wat op 23 Maart 1938 tot die tydelike rang van majoor bevorder is, is deur die Britse militêre outoriteite goedgekeur, maar sers.-maj. Barber se geval is afgewys. Sy dienste was by die Army School of Physical Training, Aldershot, benodig omdat genoemde inrigting self 'n tekort aan opgeleide sersant-majoors ondervind het. Op 21 Februarie 1939 het die Britse Oorlogskantoor ewenwel toestemming verleen dat sers.-maj. Barber sy dienste in die Unie-Verdedigingsmag tot op 30 Junie 1940 kan voortsit.

$\mathrm{Na}$ verdere vertoë deur die militêre owerhede in Suid-Afrka het die Britse Oorlogskantoor op 15 Januarie 1940 goedkeuring verleen dat sers.-maj. Barber in Suid-Afrika kan bly totdat sy dienste nie meer benodig word nie of totdat die Britse Oorlogskantoor weer vra dat hy na Aldershot moet terugkeer.

In Mei van dieselfde jaar het sers.-maj. Barber aansoek gedoen om vanaf die Britse Leër na die S.A. Staande Mag oorgeplaas te word.

Dié aansoek is deur die Britse Militêre owerhede goedgekeur en hy is vanaf 1 Januarie 1941 met die tydelike rang van luitenant as instrukteur by die S.A. Militêre Kollege op Voortrekkerhoogte ingedeel. Hierdie offisier het voltydse militêre diens in die Unie-Verdedigingsmag op die gebied van liggaamlike opleiding verrig tot hy op 13 Januarie 1946 met die rang van kaptein uit die diens getree het.

\subsection{Vakatures vir Instrukteurs in Liggaamlike Opleiding}

Die feit dat daar in 1940 nog nie voldoende instrukteurs vir die liggaamlike opleidingsbehoeftes aan die Unie-Verdedigingsmag opgelei was nie, word weerspieël deur die dienstermynverlenging van maj. Barlow en sers.-maj. Barber. 'n Ander faktor waaruit hierdie toestand ook blyk, was die publisering van vakatures vir instrukteurs in liggaamlike opleiding asook vir algemene militêre instrukteurs in dagblaaie. 
Luidens bogenoemde advertensies is 'n kursus vir die opleiding van die Unie-Verdedigingsmag, asook belangstellende burgerlikes, as instrukteurs in liggaamlike opleiding en ander militêre vakke vanaf 10 April 1940 aan die S.A. Militêre Kollege op Voortrekkerhoogte gereël. Die kursus sou 4 maande duur.

Voornemende aansoekers moes van blanke afkoms, ongetroud en geneeskundig geskik wees. Hulle moes oor 'n borsmaat van $33 \frac{1}{2} \mathrm{dm}$. beskik en nie korter as $5 \mathrm{vt}$. $6 \mathrm{dm}$. wees nie. In die geval van kandidate vir liggaamlike opleiding moes hulle nie onder die ouderdom van 18 jaar of bo 35 jaar wees nie en oor 'n st. VII-sertifikaat beskik.

Voorts is vermeld dat ten volle gekwalifiseerde instrukteurs bo die ouderdom van 45 jaar in buitengewone gevalle aangestel kan word.

Kandidate wat oor bogenoemde kwalifikasies beskik, sou voor 'n keurraad verskyn, waarna hulle geneeskundig ondersoek sou word.

Op 8 April 1970 het kandidate voor 'n finale keurraad verskyn. Beide maj. Barlow en kapt. D. H. Craven, is deur die adjudant-generaal as lede van die keurraad benoem.

Personeel wat deur middel van hierdie kursus as instrukteurs in liggaamlike opleiding en ander vakke gekwalifiseer het, sou vir 'n tydperk van 4 jaar of solank die oorlog sou duur, watter tydperk ookal die kortste sou wees, aangestel word.

Dit was 'n oorlogstydse maatreël en daarop gemik om voldoende instrukteurs beskikbaar te hê om onderrig aan 'n steeds toenemende aantal dienspligtiges te verskaf.

\subsection{Liggaamlike Opleidingskursusse gedurende 1940}

Die volgende kursusse is aan bogenoemde inrigting vir 1940 beplan:

Vier kwalifiserende kursusse vir assistent-instrukteurs in Liggaamlike Opleiding;

twee assistent-instrukteurskursusse vir die Liggaamlike Opleiding van kadetoffisiere;

een kursus vir die opleiding van atletiekinstrukteurs;

een kursus vir die opleiding van boksinstrukteurs;

een herhalingskursus vir Staande Mag-onderoffisiere wat reeds as instrukteurs en assistent-instrukteurs in Liggaamlike Opleiding gekwalifiseer is; en

een gevorderde kursus in Liggaamlike Opleiding.

10.5. Aanstelling van kapt. D. H. Craven as ko-ordinerende Offisier, Liggaamlike Opleiding, op Voortrekkerhoogte

Kapt. D. H. Craven, wat na sy terugkeer uit die buiteland vanaf 23 November 1939 as Organiseerder van Liggaamlike Opleiding in die Unie-Verdedigingsmag aangestel is, is met ingang van 11 Junie 1940 na die Tak Liggaamlike Opleiding van die S.A. Militêre Kollege verplaas waar hy op 17 Junie van dieselfde jaar as hoofinstrukteur in Liggaamlike Opleiding by genoemde inrigting aangestel is. Op 29 Junie 1940 is hy tot die tydelike rang van majoor bevorder.

Die destydse adjunk-hoof van die Generale Staf, brig.-genl. G. E. Brink, C.B., C.B.E., D.S.O., het op 8 Julie 1940 bekend gemaak dat maj. Craven, hoofinstrukteur van die Tak Liggaamlike Opleiding van die S.A. Militêre Kollege vanaf genoemde datum, ook as die ko-ordinerende outoriteit van alle liggaamlike en rekreatiewe opleiding in die Voortrekkerhoogte-gebied aangestel is. 
Maj. Craven was verantwoordelik vir die toesighou oor alle liggaamlike opleidingspersoneel wat diens by die eenhede in die Voortrekkerhoogte-gebied verrig het asook vir die remediële opleiding van die reeds genoemde K-pelotons van die Spesiale Diensbataljon wat op daardie stadium nog onder beheer van die bevelvoerder van laasgenoemde eenheid gebly het sover dit die algemene militêre opleiding, dissipline en administratiewe aangeleenthede betref. Die remediële en liggaamlike opleiding van lede van die K-pelotons moes in noue samewerking met die direkteur-generaal Geneeskundige Diens, geskied. Die spesiaal opgeleide personeel wat vir hierdie doel aangewend is, het onder beheer van die hoofinstrukteur van die Tak Liggaamlike Opleiding van die S.A. Militêre Kollege geval. Die bevelvoerder van die Spesiale Diensbataljon is versoek om met maj. Craven te skakel rakende die opleiding en gesondheid van die lede van die K-pelotons.

Bykomend tot sy aanstelling as hoofinstrukteur van die Tak Liggaamlike Opleiding van die S.A. Militêre Kollege het maj. Craven steeds die aanstelling as Stafoffisier Liggaamlike Opleiding behou. In hierdie hoedanigheid sou hy alle opleidingsinrigtings in die Unie-Verdedigingsmag besoek, inspeksies uitvoer en bevelvoerders en verantwoordelike liggaamlike opleidingspersoneel adviseer en rapporte m.b.t. dié vakgebied uitbring.

'n Verdere verwikkeling het op 14 Augustus 1940 gevolg toe die adjunkhoof van die Generale Staf op genoemde datum 'n instruksie uitgereik het dat alle beskikbare instrukteurs in liggaamlike opleiding in die Voortrekkerhoogte-gebied vanaf 16 Augustus 1940 na die Tak Liggaamlike Opleiding van die S.A. Militêre Kollege verplaas word. Hul dienste sou vanuit hierdie inrigting aan eenhede soos die Spesiale Diensbataljon, die K-pelotons en ander eenhede beskikbaar gestel word. Hierdie reëling was noodsaaklik omdat die owerhede van die Unie-Verdedigingsmag op dié tydstip nog steeds 'n tekort aan gekwalifiseerde instrukteurs op hierdie besondere vakgebied ondervind het.

Om te verseker dat die dienste van die liggaamlike opleidingsinstrukteurs doeltreffend aangewend sou word, moes eenheidsbevelvoerders die hoofinstrukteur van die Tak Liggaamlike Opleiding in kennis stel wat die geskikte tye vir hulle sou wees om liggaamlike opleiding aan te bied. Op hierdie manier is die liggaamlike opleidingsbehoeftes van alle eenhede in die Voortrekkerhoogte-gebied geko-ordineer.

Op 25 Oktober 1940 is aan alle eenheidsbevelvoerders in die Unie-Verdedigingsmag opdrag gegee dat daaglikse periodes van 45 minute deur alle lede van die Unie-Verdedigingsmag aan liggaamlike opleiding bestee moet word. Vanaf genoem $d s$ datum was dit dan ook verpligtend dat liggaamlike opleiding 'n deel van alle militêre opleidingsprogramme moet vorm. Daar is bepaal dat liggaamlike opleiding tussen 8 uur en 4 uur van elke werksdag, behalwe Saterdae, uitgevoer moet word. Hierdie reëling is getref om te verseker dat daar in die basiese fiksheids- en ontspanningsbehoeftes van alle lede van die Unie-Verdedigingsmag voorsien word.

\section{6. 'n Nuwe Benadering ten opsigte van Liggaamlike Opleiding}

Soos reeds vermeld, het maj. Barlow by sy aankoms in Suid-Afrika bevind dat daar geen georganiseerde stelsel van liggaamlike opleiding in die UnieVerdedigingsmag bestaan het nie, terwyl daar ook weinig opgeleide instrukteurs was en 'n sentrale inrigting, waar instrukteurs opgelei kan word, ontbreek het.

Hierdie probleme is opgelos deur die stigting van 'n sentrale opleidingsinrigting, bekend as die Tak Liggaamlike Opleiding, waar militêre instrukteurs van die Unic-Verdedigingsmag in liggaamlike opleiding opgelei is. Die insluiting van 
periodes vir liggaamlike opleiding in die militêre opleidingsprogramme van die Unie-Verdedigingsmag het daartoe bygedra dat hierdie soort opleiding in genoemde organisasie op 'n behoorlike grondslag geplaas is.

Die stelsel van liggaamlike, opleiding wat sedert die koms van maj. Barlow en tot voor die uitbreek van die Tweede Wêreldoorlog in die Unie-Verdedigingsmag in swang was, was op die metode van opleiding by Aldershot gebaseer. Danksy die pogings van maj. Barlow en sy assistent, sers.-maj. Barber, het die Suid-Afrikaanse militêre instrukteurs 'n deeglike kennis van die teorie en praktyk van liggaamlike opleiding opgedoen.

Intussen het maj. Craven geleentheid gehad om 'n studie van liggaamlike opleiding in Engeland en verskeie ander lande in Europa te maak. Een van sy opdragte was om 'n deeglike studie van die onderskeie metodes en stelsels van liggaamlike opleiding in militêre verband te maak met die doel dat hy by sy terugkeer 'n stelsel, een aan die omstandighede, natuur en gewoontes in Suid-Afrika, in werking sal stel.

By sy terugkeer in Suid-Afrika aan die einde van 1939, is maj. Craven ook aangestel op 'n spesiale onder-komitee wat die opdrag gehad het om 'n eie liggaamlike opvoedingstelsel vir die Nasionale Adviserende Raad vir Liggaamlike Opvoeding, 'n liggaam wat die regeringsbeleid t.o.v. liggaamlike opvoeding in die Unie van Suid-Afrika geadministreer het, saam te stel. Dit was as gevolg van sy verbintenis met bogenoemde onder-komitee dat maj. Craven in die geleentheid was om sy stelsel van spele, wat hy beskou het as die nasionale stelsel van liggaamlike opvoeding vir Suid-Afrika, saam te stel.

Die militêre owerhede van die Unie-Verdedigingsmag het maj. Craven in 1940 die geleentheid gegee om sy stelsel van spele, waarmee hy die soldate fiks moes kry vir oorlogvoering, ten uitvoer te bring.

In 'n memorandum oor liggaamlike opleiding in die Unie-Verdedigingsmag wat in November 1940 opgestel is, is vermeld dat die spelestelsel van maj. Craven die volgende voordele bo die Aldershotmetode vertoon:

1. Dit maak voorsiening vir oorlogstydse toestande waar 'n groot aantal persone oor 'n kort tydperk liggaamlik en geestelik vir oorlogvoering voorberei moet word.

2. Dit skakel die probleem van uitrusting uit, deurdat slegs 'n geringe hoeveelheid uitrusting, wat maklik self vervaardig kan word, benodig word.

3. In die derde plek is in die memorandum daarop gewys dat die spelestelsel spesifiek Suid-Afrikaans is. Daardeur gryp dit die verbeelding van die individu aan en spoor dit hom sodoende aan om die beste te lewer.

\subsubsection{Implementering van die Spelestelsel}

Ten einde die nuwe stelsel van liggaamlike opleiding in die Unie-Verdedigingsmag te implementeer, is kursusse vir die opleiding van instrukteurs op hierdie vakgebied aan die Tak Liggaamlike Opleiding van de S.A. Militêre Kollege gereël. Teen November 1940 was daar reeds 120 opgeleide instrukteurs in liggaamlike opleiding in die Unie-Verdedigingsmag werksaam. Hierna het die militêre owerhede in Suid-Afrika met 'n stelsel begin om eenheidsinstrukteurs in liggaamlike opleiding te lei. Om die nuwe stelsel aan dienende lede van die Unie-Verdedigingsmag tuis te bring, is vertonings - op Voortrekkerhoogte, Premiermyn en Potchefstroom - in 1940 gereël (38). Die skema is in die UnieVerdedigingsmag uitgebrei en vertonings van die spelestelsel is in November van dieselfde jaar in Kaapstad gereël (65). 


\subsubsection{Doel van die Spelestelsel}

In die Cape Argus van 23 November 1940 is berig dat die volgende 6 doelstellings die nuwe spelestelsel ten grondslag lê:

1. Om die soldate deur middel van spele liggaamlik en geestelik fiks te maak.

2. Om deur middel van spele te rus.

3. Om met genot oefening te verkry.

4. Om 'n beter vorm van opvoeding daar te stel.

5. Om manne as sportmanne op te lei.

6. Om sportmanskap te vorder deur die regte gesindheid teenoor jouself, die spel, jou span en jou teenstanders aan te kweek (65).

\subsubsection{Kenmerke van die Spelestelsel}

Die nuwe stelsel het ongeveer 300 groter en kleiner spele behels wat deur groot en klein groepe beoefen kon word. Hierdie spele het o.m. aanslaanrugby, handsokker, netbal, toutrek, jukskei en handbal behels*.

'n Ander besondere kenmerk van die nuwe opleidingsmetode was dat alle spele op die beginsel van spoed en viriliteit gebaseer was sonder dat daar enige gevaar bestaan het dat dit in rofheid ontaard (65). Hierdie spele het die belangstelling van deelnemers geprikkel en was só beplan dat dit uithouvermoë en krag meer ontwikkel het as die voormalige formele stelsel van liggaamlike opleiding (55).

'n Voordelige kenmerk van hierdie stelsel was ook die feit dat min uitrusting, geen spesiale geboue en velde benodig was vir die uitvoering daarvan nie. Dic benodighede het bestaan uit medisyneballe, sokkerballe, e.d.m. Al hierdie uitrusting kon maklik deur die soldate vervoer word en die gevolg wat dat hulle op enige plek aan liggaamlike opleiding kon deelneem solank hulle net 'n oop spasie kon vind (55).

\subsection{Die Opleiding van Liggaamlike Opleidingsinstrukteurs in 1941}

Terwyl die nuwe spelestelsel inslag in die opleiding van jong soldate van die Unie-Verdedigingsmag gevind het, is 'n reeks kursusse vir die opleiding van liggaamlike opleidingsinstrukteurs aan die Tak Liggaamlike Opleiding van die S.A. Militêre Kollege beplan. Dié kursusse kan in die volgende groepe verdeel word:

Twee gevorderde instrukteurskursusse in Liggaamlike Opleiding;

elf instrukteurskursusse in Liggaamlike Opleiding en Spele;

vyf assistent-instrukteurskursusse in Liggaamlike Opleiding insluitende Remediële Opleiding;

drie kursusse vir die opleiding van skeidsregters en beoordelaars in bokswedstryde;

een Liggaamlike Opleidingskursus vir skool-kadetoffisiere;

een kursus vir bataljon (eenheids) Liggaamlike Opleidingsinstrukteurs;

een leierskursus in Liggaamlike Opleiding en Spele vir lede van die Vroue-Leërhulpdiens en Vroue-hulpdiens van die Lugmag;

drie assistent-instrukteurskursusse in Liggaamlike Opleiding vir lede van laasgenoemde Vroue-Hulpdienste.

Dit dien hier vermeld te word dat hierdie kursusse verskillende tydsdure, van 4 maande en 1 week, gehad het.

* Die Cape Argus berig op 23 November 1940 dat elke spier in 'n deelnemer se liggaam op 'n aangename en genotvolle manier geoefen word en dat dit ratsheid en wakkerheid van gees tot gevolg het. 


\subsection{Uitrustingstabelle}

Die skaal waarop liggaamlike opleidingsuitrusting in 1941 aan opleidingsinrigtings met 1000 en minder soldate deur die Staat voorsien is, word in die volgende tabel uiteengesit:

\begin{tabular}{|c|c|c|c|c|c|}
\hline Medisyneballe & & $\cdots \cdots$ & $\ldots \ldots$ & $\ldots \ldots$ & \\
\hline Sokkerballe & $\ldots \ldots$ & $\ldots \ldots$. & $\ldots \ldots$. & $\ldots \ldots$. & $\ldots \ldots$ \\
\hline Tennisballe (verkieslik geb & uiktes) & & $\ldots \ldots$. & $\ldots \ldots$ & $\ldots \ldots$ \\
\hline Rugbyballe & $\ldots \ldots$. & $\ldots \ldots$ & & $\ldots \ldots$ & $\ldots . .$. \\
\hline Broeksma-toue vir toutrek & & & $\ldots \ldots$ & $\ldots \ldots$ & $\ldots \ldots$ \\
\hline Sagtebal, stelle ...... & $\ldots$ & $\ldots \ldots$ & & $\ldots \ldots$. & $\ldots \ldots$ \\
\hline Bokshandskoene, stelle & $\ldots \ldots$. & & $\ldots \ldots$. & $\ldots$ & $\ldots \ldots$ \\
\hline Gewigte vir gewigstoot & & $\ldots \ldots$ & & & $\ldots \ldots$ \\
\hline Spiese $\quad \ldots \ldots . ., \ldots \ldots$ & $\ldots$ & $\ldots \ldots$ & & $\ldots$ & $\ldots$ \\
\hline Standers vir hoogspring & $\ldots$ & & $\ldots \ldots$ & $\ldots \ldots$ & . \\
\hline Standers vir paalspring & $\cdots$ & $\ldots$ & & $\cdots \cdots$ & $\ldots$ \\
\hline Werpskywe & $\ldots$ & & 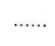 & $\ldots$ & $\ldots$ \\
\hline Pale vir paalspring & $\ldots \ldots$ & $\ldots \ldots$ & & $\ldots \ldots$ & 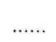 \\
\hline Dwarslatte vir paalspring & $\ldots \ldots$ & $\ldots \ldots$ & $\ldots \ldots$ & $\ldots \ldots$ & \\
\hline
\end{tabular}

Voorsiening is ook vir militêre eenhede met meer as 2000 of 3000 lede gemaak. In dergelike gevalle is die skaal van uitreiking verdubbel of verdriedubbel.

\subsection{Uitbreiding van die Tak Liggaamlike Opleiding van die S.A. Militêre Kollege}

Voor 1941 het die organisasie van bogenoemde Unie-Verdedigingsmaginrigting die volgende personeel ingesluit: Een bevelvoerder, twee offisier-instrukteurs, vyf instrukteurs met die rang van sersant, een klerk met die rang van korporaal en een klerk sonder 'n rang.

Op 24 Mei 1941 het die adjudant-generaal van die Unie-Verdedigingsmag bekend gemaak dat die organisasie van die Tak Liggaamlike Opleiding van die S.A. Militêre Kollege uitgebou word om die volgende bykomende personeel in te sluit: Een Master at Arms met die rang van kaptein, een adjudant-kwartiermeester met die rang van luitenant, 'n sersant-majoor, ses instrukteurs met die rang van sersant, een offisier-instrukteur vir die Vroue-Leërhulpdiens met die rang van luitenant, twee instruktrises met die rang van sersant en een klerk met die rang van sersant.

Hierdie diensstaat-uitbreiding kan daaraan toegeskryf word dat 'n steeds groter getal instrukteurs in liggaamlike opleiding opgelei moes word om in die behoeftes van die Unie-Verdedigingsmag te voorsien.

\subsection{Uitbreiding van Leerplanne}

Die plaaslike militêre owerhede het in 1941 besluit dat die leerplanne, wat tydens die opleiding van liggaamlike opleidingsinstrukteurs aan die S.A. Militêre Kollege gevolg is, uitgebrei moet word. Op 27 Oktober van dieselfde jaar is gevolglik aan die kommandant van die S.A. Militêre Kollege versoek om: teurs in te sluit.

1. Meer lesings oor anatomie en fisiologie in die leerplanne van instruk-

2. Aandag aan toegepaste anatomie en fisiologie te skenk.

3. Lesings oor mediese aspekte van liggaamlike opleiding te reël en om rolprente oor aspekte van dié tak te vertoon. 
Bogenoemde vakke moes progressief en sistematies gedurende instrukteurskursusse in liggaamlike opleiding aangebied word.

In die geval van remediële opleidingskursusse wat slegs 6 weke geduur het, is voorgeskryf dat lesings wat handel oor remediële probleme en die Liggaamlike Opleidingsbataljon, met spesiale verwysing na sy geskiedenis en doelstellings, ingesluit moet word. Laasgenoemde lesings moet deur die mediese offisiere van die Liggaamlike Opleidingsbataljon gegee word.

In die geval van lesings oor die Liggaamlike Opleidingsbataljon, kan die dienste van enige offisier van genoemde eenheid gebruik word. Ook kan die lesings deur enige persoon wat met die stigting daarvan te doen gehad het, aangebied word.

Die insluiting van hierdie vakke in die leerplanne het beslis daartoe bygedra dat die basiese teoretiese kennis van die instrukteur op sy vakgebied verhoog is.

\subsection{Liggaamlike Opleiding in die Vroue-hulpdienste}

\subsubsection{Agtergrondskets}

Die geskiedenis van die Vroue-hulpdienste in die Unie-Verdedigingsmag gaan tot 1938 terug toe 'n sekere mej. M. Egerton-Bird, 'n lid van die Randse vliegklub, 'n skema met haar medelid mej. E. Percival-Hart bespreek het om die vliegkuns goedkoper te kan beoefen en om lede daarin op te lei met die oog op hulpverlening gedurende nasionale noodtoestande.

Hierdie skema is met geesdrif deur lede van die verskeie vliegklubs ontvang. Die gevolg was dat 'n vergadering deur verskeie vooraanstaande lede van die onderskeie vliegklubs gehou is. Teenwoordig op hierdie vergadering was mej. Doreen Hooper, later bekend as mev. Doreen Bunning, wat as voorsitter gekies is. Mej. M. Egerton-Bird het as sekretaresse van die vergadering opgetree. Vervolgens het hulle saam met mejj. Joan Blake, E. Percival-Hart, S. Starfield en mev. Celliers begin organiseer. Hierdie groep het die South African Womens Aviation Association gestig. Mev. Denys Reitz is tydens 'n vergadering wat in 1938 in Johannesburg gehou is, gevra om voorsitter van die pas gestigde organisasie op te tree. $\mathrm{Na}$ hierdie vergadering, waartydens 'n hele aantal rekrute ingeskrywe is, het bogenoemde organisasie vinnig uitgebrei. Dit was die begin van die V.L.H.D.organisasic.

Die uitbreek van die Tweede Wêreldoorlog in 1939 het tot gevolg gehad dat die getalle van die Vroue-Lughulpdiens tot ongeveer 3000 lede gestyg het. 'n Groot parade is deur dié organisasie in Johannesburg gehou wat deur o.a. die destydse direkteur-generaal van die S.A. Lugmag bygewoon is. Tydens hierdie parade is die Vroue-hulpdiens Lugmag (V.H.L.M.) as 'n hulpeenheid van die S.A. Lugmag verwelkom.

In Mei 1940 het die destydse Hoof van die Generale Staf, genl.-maj. sir Pierre van Ryneveld, aangekondig dat die V.H.L.M. 'n deel van die Unie-Verdedigingsmag vorm.

In 1941 was daar ongeveer 5000 lede van die V.H.L.M. en Vroue-Leërhulpdiens (V.L.H.D.) in vrouekampe gehuisves. Die grootste was op Voortrekkerhoogte geleë. 2de lt. (mej.) Barrett is in dieselfde jaar as sportoffisier vir die dames aangestel $(80: 93)$. 


\subsubsection{Liggaamlike Opleiding in die Vroue-hulpdienste}

Die eerste taak wat aan 2de 1t. (mej.) M. A. Barrett opgedra is, was om 'n studie van die aard van die werk van die hulpdienste te doen. Dit het gewissel van sein- en klerikale- tot vliegopleiding. Hierbenewens moes 2de lt. (mej.) Barrett die metode, waarvolgens 'n sportprogram opgestel kon word, asook die fisieke toestand van die lede bepaal. In laasgenoemde verband het lt. (mej.) Barrett in 'n referaat, $(80: 74)$ wat sy tydens die eerste kongres vir Liggaamlike Opvoeding, wat in 1945 te Stellenbosch gehou is, verklaar dat $75 \%$ van die rekrute oor geen of weinig agtergrond ten opsigte van liggaamlike opvoeding beskik het nie. Lede wat nie 'n goeie houding besit en voorheen aan gimnastiek en spele op skool deelgeneem het, was baie minder in aantal as dié wat aan houdingsgebreke soos verkorte strekspiere van die heupe, kyphosis, lordosis en platvoete gely het.

As gevolg hiervan was dit noodsaaklik om 'n reeks mobiliserende en korrektiewe oefeninge saam te stel sodat individue in die minimum tyd maksimum voordeel uit hierdie oefenreekse, wat as die „Daaglikse Agt” bekend gestaan het, kon trek $(80: 74)$.

Die ,Daaglikse Agt” het die volgende behels:

1. 'n Aktiewe oefening gevolg deur voetoefeninge.

2. 'n Oefening vir die skouer en bo-rug om die ontstaan van ,'n kantoorboggel" teen te gaan.

3. Rompbewegings om 'n holrug te verlig en te herstel.

4. Beenoefeninge, insluitende 'n voetversterkende oefening.

5. Sywaartse buigings.

6. Heup- en buikspieroefeninge om verkorte strekspiere te versterk en die losmaak van heupgewrigte te bevorder.

7. Oefeninge om posturale spiere te versterk.

8. Spele $(80: 74)$.

In Mei 1940 is 2de lt. (mej.) M. A. Barrett as lid van die Inspektoraat van Liggaamlike Opleiding in die Unie-Verdedigingsmag aangestel. Sy was verantwoordelik vir die liggaamlike opleiding en sport van die Vroue-hulpdienste dwarsdeur die Unie-Verdedigingsmag.

Omdat die kampe, waarin die Vroue-hulpdienste gehuisves was, dwarsoor die lengte en breedte van die Unie van Suid-Afrika versprei was en die aantal Liggaamlike Opvoedkundiges in die Unie-Verdedigingsmag beperk was, was dit noodsaaklik dat leidsters op hierdie vakgebied uit die geledere van die diensdoende vroue opgelei moes word.

Die diensstaat van die Tak Liggaamlike Opleiding van die S.A. Militêre Kollege het in Mei 1941 reeds voorsiening vir een vroulike offisier en twee instrukteurs met die rang van sersant gemaak.

Geriewe vir die opleiding van instruktrises in liggaamlike opleiding het dus reeds bestaan.

Ten einde die opleiding van instruktrises in die Unie-Verdedigingsmag tot uitvoer te bring, is mej. F. M. Maskew op 16 Mei 1941 by die Tak Liggaamlike Opleiding van die S.A. Militêre Kollege ingedeel om een van die sersantposte te vul, terwyl 2de lt. (mej.) Barrett vanaf 19 Mei 1941 as offisier-instrukteur, die datum waarop sy bevorder is tot die rang van luitenant, daarheen verplaas is.

In Mei 1941 is die liggaamlike opleidingskema vir lede van die Vrouehulpdienste in die Unie-Verdedigingsmag van stapel gestuur, nadat die volgende kursusse by die Tak Liggaamlike Opleiding van die S.A. Militêre Kollege beplan 
'n Leierkursus in Liggaamlike Opleiding wat een maand geduur het, 'n assistent-instrukteurskursus van drie maande en 'n gevorderde instrukteurskursus in Liggaamlike Opleiding wat twee maande geduur het $(80: 94)$.

Die leerplan van die kursus van 3 maande het o.a. die volgende onderwerpe ingesluit:

1. Fikshou-oefeninge.

2. Skandinawiese danse.

3. Afrigting van spele.

4. Elementêre anatomie.

5. Kampadministrasie, die hou van vergaderings, die skryf van notule, die hantering van gelde e.d.m.

6. Kamporganisasie, soos die organisasie van sportklubs, die voorsiening en instandhouding van sportvelde, e.d.m.

7. Vermaaklikhede, soos die organiseer van danse.

8. Die aankoop en versorging van uitrusting.

9. Die organisasie van toernooie t.w. Amerikaanse- en uitklopmetodes (80: 94).

Lede wat hierdie kursus suksesvol voltooi het, is as korporaals en sersante na die verskillende kampe gestuur. Nadat hierdie personeel verskeie maande diens verrig het as instrukteurs in liggaamlike opleiding en deur hulle bevelvoerders aanbeveel is, kon hulle 'n gevorderde instrukteurskursus in liggaamlike opleiding volg. Indien hulle hierdie kursus voltooi, kon hulle vir aanstelling as offisiere in aanmerking kom.

In die leerplan van die kursus vir gevorderde instruktrise in liggaamlike opleiding is voorsiening gemaak vir:

1. Fikshou-oefeninge.

2. Skandinawiese danse.

3. Medaubaloefeninge.

4. Verdere afrigting van spele.

5. Die verkryging van die Koninklike Lewensreddingsvereniging se brons- en silwermedaljes.

6. Die organiseer van spanatletiek-byeenkomste, swemgalas, atletiekbyeenkomste en die organiseer van rekreatiewe opleiding vir groot aantalle dames en mans ( $80: 95)$.

Die doel met die afrigting van spele was om elke instruktrise toe te rus met voldoende kennis van spele om lede, wat in die siviele lewe nie die geleentheid gehad het om aan spele deel te neem nie, in die spel van hul keuse af te rig (80:95).

Vanaf 1 Julie 1941 is 1t. (mej.) Barrett op die personeel van die Direkteur van Militêre Opleiding te Verdedigingshoofkwartier, Pretoria, aangestel, terwyl 2de lt. (mej.) Stoltz by die Tak Liggaamlike Opleiding van die S.A. Militêre Kollege as instruktrise diens aanvaar het. In samewerking met lt. (mej.) Barrett was sy o.a. verantwoordelik om kursusse vir die opleiding van instruktrises vir die Vroue-hulpdienste te beplan.

In 1942 het 'n nuwe situasie in die Unie-Verdedigingsmag ontstaan. Lede van die Vrous-hulpdienste is in die kusverdedigingstelsels geëmplojeer. Uit die aard van hulle werk het sommige van hulle spierbeserings en ander gebreke opgedoen. Die gevolg was dat 'n daaglikse periode liggaamlike opleiding en spele in 'n opleidingskursus, wat een maand geduur het alvorens die dames diens by die kusverdedigingseenhede aanvaar het, ingesluit is. Eenvoudige medisynebal-, maagspier- en voetoefeninge is gedoen om die maag-, arm- en voetspiere te versterk (80:96). 
Aan die begin van 1943 het die beleid t.o.v. sportoffisiere in die S.A. Lugmag 'n verandering ondergaan. Die militêre owerhede het besluit dat die jong sportoffisiere in die S.A. Lugmag vir vliegopleiding beckikbaar gestel moet word en dat ' $n$ sportoffisier - 'n man of 'n vrou - slegs 'n organiseerder moet wees (80:96). Hierdie reëling het meegebring dat lede van die Vroue-hulpdiens Lugmag die organiseer van sport in die S.A. Lugmag van hul manlike kollega's oorgeneem het.

Dit is ook belangrik om hier te vermeld dat die Vroue-hulpdiens aan verskeie vertonings in liggaamlike opleiding deelgeneem het. Sedert 1941 is 55 verskillende vertonings dwarsdeur die land gegee. Die aantalle wat aan die vertonings deelgeneem het, het voortdurend gewissel. So is daar in 1942 'n vertoning op die $W$ anderers-terrein in Johannesburg gegee waaraan 1000 lede van die V.H.L.M. deelgeneem het, terwyl 7 instruktrises in 1944 'n klein vertoninkie aangebied het $(80: 96)$.

Die einde van die Tweede Wêreldoorlog het ook 'n einde aan die werksaamhede van die Vroue-hulpdienste in die Unie-Verdedigingsmag meegebring.

\subsection{Liggaamlike Opleiding vir Krygsgevangenes in Suid-Afrika}

Verdere voorsiening op die gebied van liggaamlike opleiding in die UnieVerdedigingsmag is op 7 Mei 1941 gemaak toe die destydse direkteur van Militêre Opleiding 'n aanbeveling aan die adjudant-generaal voorgelê het waarin voorgestel is dat die beoefening van liggaamlike en rekreatiewe opleiding na krygsgevangenes in kampe in Suid-Afrika uitgebrei word. Hy het verder voorgestel dat die destydse offisier belas met sportaangeleenthede vir krygsgevangenes 'n kursus in liggaamlike opleiding moet bywoon en dat hy by voltooiing daarvan 'n soortgelyke kursus vir gekeurde krygsgevangenes reël. Dit sal die krygsgevangenes dan in staat stel om liggaamlike en rekreatiewe opleiding aan hul eie mense aan te bied. Dié voorstelle is op 31 Mei 1941 deur die Suid-Afrikaanse militêre owerhede goedgekeur.

Die program is op die volgende gebaseer:

1. Alle ontspannings- en sportaktiwiteite, insluitende konserte wat in die krygsgevangenekampe gereël word, moet onder die direkte beheer van 1t. P. F. Theron, sport- en liggaamlike opleidingsoffisier van die krygsgevangenekamp, Sonderwater, staan.

2. 'n Italiaanse offisier moet in elke blok waarin die krygsgevangekampe verdeel is, aangestel word en het bekend gestaan as die Capo Sportivo. Hierdie Italiaanse offisier sou die alleenreg besit om sport en ontspanningsaktiwiteite te reël en beheer daaroor uit te oefen. Hy moes ook verantwoordelikheid aanvaar indien daar van tydprogramme afgewyk word. Verder was dit sy taak om kompetisies tussen spanne van sy blok en dié van ander blokke in dieselfde kamp te reël. Kompetisies tussen die verskillende blokke kon alleen plaasvind nadat dit deur die Capi Sportivi van die verskillende blokke gereël was.

Lt. Theron, wat die program saamgestel het, het ook in die vooruitsig gestel dat 'n liggaamlike opleidingsklas van 40 instrukteurs (39 instrukteurs en een hoofinstrukteur) in elke blok van die kamp gestig word. Die liggaamlike opleidings- en sportbedrywighede is gedurende periodes wat op die daaglikse rooster vir die krygsgevangenes verskyn het, uitgevoer. Bykomend tot hulle take as instrukteurs in liggaamlike opleiding, moes die instrukteurs ook die Italiaanse sportoffisier bystaan deur beheer oor verskeie spele uit te oefen en om konserte te reël. Lede van genoemde liggaamlike opleidingsinstrukteursklas moes toesien dat die spele waarvoor hulle verantwoordelik was, uitgevoer word en in hierdie verband moes hulle aan die hoofinstrukteur verslag doen. 
4. Die hoofinstrukteur moes 'n register byhou waarin inskrywings met betrekking tot die dienste van sy instrukteurs gedoen word. Die name van die persone waaruit die sportspanne saamgestel is, moes deur die hoofinstrukteur aangeteken word sodat die verskillende spanne hulle reeds georganiseerd op die sportveld kon aanmeld.

\subsubsection{Werksaamhede van die Klasinstrukteurs}

Die werksaamhede van bogenoemde instrukteurs kan soos volg saamgevat word:

1. Die klasinstrukteurs moet vir die liggaamlike opleidingsperiodes behoorlik geklee in die drag wat vir dié doel voorsien is onder beheer van die hoofinstrukteur op parade verskyn by watter gelleentheid die hoofinstrukteur 'n presensielys opstel. instruksies.

2. Hierna rapporteer die hoofinstrukteur aan die Capo Sportivo vir

3. Die hoofinstrukteur moet ook 'n register byhou waarin die name van die teenwoordige klasinstrukteurs en die redes vir afwesigheid van ander klasinstrukteurs aangeteken word.

4. Kompetisies moet ook tussen die klasinstrukteurs van die verskillende blokke van die kampe gereël word.

5. Vir die doeleindes van liggaamlike opleiding en sport is die krygsgevangenekampe in kompanies verdeel. Indien 'n kompanie te groot was om deur een klasinstrukteur hanteer te word, is dit verder onderverdeel en is 'n klasinstrukteur in beheer van elke onderverdeelde groep geplaas.

6. Die klasinstrukteurs is in groepe verdeel en 'n sportsoort is aan elke groep toegesê waarvoor dié groep verantwoordelik was. Spanne is vir elke sportsoort gevorm en die verantwoordelike instrukteurs moes dan sorg dra dat die manne besig bly vir die duur van die periode.

7. Die klasinstrukteurs moes aan die Capo Sportivo met betrekking tot die aktiwiteite wat deur hulle groepe uitgevoer is, rapporteer.

8. Lt. Theron het ook daarop gewys dat indien die aantal klasinstrukteurs onvoldoende blyk te wees hulle aangevul kan word.

\subsubsection{Liggaamlike Opleiding van Kompanies}

Soos reeds vermeld is die krygsgevangenekampe in kompanies verdeel. Liggaamlikc opleiding is volgens 'n rooster uitgevoer. Een of twee klasinstrukteurs is in bevel van 'n kompanie geplaas. Voordat die liggaamlike opleidingsperiode 'n aanvang geneem het, is 'n presensielys deur die kompanieleier voltooi. Indien die kompanie te groot was om deur een instrukteur behartig te word, is dit in groepe verdeel wat dan elkeen onder leiding van 'n klasinstrukteur gestaan het. Die klasinstrukteurs moes op hul beurt ook aan die hoofinstrukteur rapporteer betreffende die liggaamlike opleiding van hul instrukteurs.

Sportsoorte wat daardie tydstip in die krygsgevangenekampe beoefen is, was boks, netbal, korfbal, sokker, stoei en rolbal.

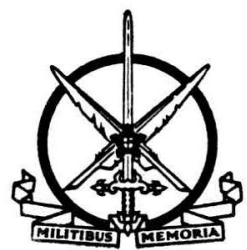




\section{Samevatting}

Gedurende die eerste helfte van die Tweede Wêreldoorlog het die klem op die gebied van liggaamlike opleiding in die Unie-Verdedigingsmag op die opleiding van instrukteurs in hierdie vakgebied geval. Die dienstermynverlenging van die twee Britse militêre instrukteurs en die aanbieding van die groot aantal liggaamlike opleidingskursusse getuig hiervan.

In 1940 is 'n nuwe benadering t.o.v. die fisieke weerbaarmaking van die Suid-Afrikaanse soldate gevolg na die instelling van maj. D. H. Craven se spelestelsel.

Die Vroue-hulpdienste is ook in 1940 as 'n eenheid van die Unie-Verdedigingsmag ingestel.

Die diensstaat van die Tak Liggaamlike Opleiding van die S.A. Militêre Kollege is in 1941 uitgebrei.

In dieselfde jaar is liggaamlike opleiding ook in krygsgevangenekampe in Suid-Afrika ingevoer.
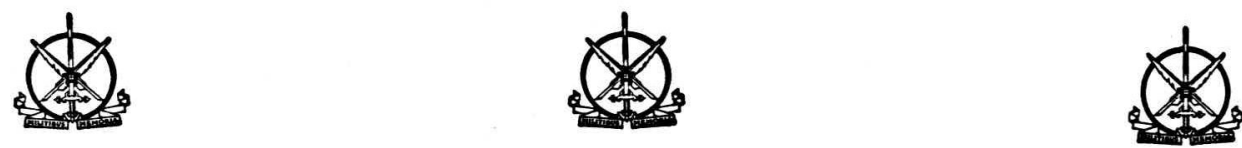


\section{LIGGAAMLIKE OPLEIDING IN DIE UNIE- VERDEDIGINGSMAG 1942-1946}

\subsection{Inleiding}

Terwyl die Tweede Wêreldoorlog op verskeie gevegsfronte voortgewoed het, het die S.A. militêre owerhede voortgegaan met die opleiding van instrukteurs in liggaamlike opleiding om sodoende te verseker wat dié jong Suid-Afrikaners wat tot die stryd toegetree het in 'n goeie staat van fisieke en geestelike fiksheid verkeer.

\subsection{Kursusse vir 1942}

Met hierdie gedagte is die volgende reeks kursusse, met wisselende tydsduur, aan bogenoemde opleidingsinrigting vir 1942 beplan:

Een Liggaamlike Opleidingskursus vir kadetoffisiere, nege kursusse in Liggaamlike Opleiding en Spele, een gevorderde kursus in Liggaamlike Opleiding vir die opleiding van instruktrises van die V.L.H.D. en V.H.L.M., die Liggaamlike Opleiding en Spele-kursusse vir lede van die V.L.H.D. en V.H.L.M.,

een atletiek-afrigterskursus,

drie assistent-instrukteurskursusse in Liggaamlike Opleiding,

ses kursusse vir die opleiding van skeidsregters en beoordelaars in bokswedstryde,

drie assistent-instrukteurskursusse vir die opleiding van lede van die V.L.H.D. en V.H.L.M.,

drie kursusse vir die opleiding van leidsters in Liggaamlike Opleiding vir lede van die V.L.H.D. en V.H.L.M.,

een gevorderde instrukteurskursus in Liggaamlike Opleiding,

drie kursusse in Liggaamlike Opleiding vir senior-offisiere,

een kursus in Liggaamlike- en Ontspanningsopleiding vir onderoffisiere, twee kursusse in Remediële Opleiding.

Dit was egter nie net in Suid-Afrika dat instrukteurs in liggaamlike opleiding opgelei is nie. Hierdie taak is ook aan die gevegsfronte voortgesit. As 'n voorbeeld kan die liggaamlike opleidingskursus wat vanaf 3 Maart tot 23 Maart 1942 in die Midde-Ooste aangebied is, vermeld word. Hierdie kursus, wat 3 weke geduur het, was 'n assistent-instrukteurskursus.

Die leerplan het o.a. die volgende onderwerpe ingesluit: Lesings oor anatomie, fisiologie, liggaamlike opleiding, die organisasie van bokstoernooie, boksreëls en atletiek is doseer, terwyl die kursusgangers praktiese onderrig in liggaamlike opleiding, boks, stoei, sagtebal, swem, aangeebal, spronge, atletiek en ongewapende gevegte ontvang het. Hierbenewens is baie aandag aan leierskap m.b.t. liggaamlike opleiding bestee. Die kursus is met 'n praktiese eksamen in leierskap, stoei, ongewapende gevegte en boks afgesluit. Ook is 'n skriftelike eksamen afgeneem.

Deur middel van hierdie soort kursusse het die offisiere, belas met die gevegsvaardigheid van die Suid-Afrikaanse soldate aan die gevegsfronte, verseker dat hulle oor opgeleide instrukteurs in hul eenhede beskik om toe te sien dat die soldate fisiek en geestelik in staat is om aan die hoë eise van die oorlogvoering te voldoen. 


\subsection{Reorganisasie van Liggaamlike Opleiding}

Die organisasie wat belas was met die opleiding van liggaamlike opleidingsinstrukteurs in die Unie-Verdedigingsmag het in 1942 voorsiening vir 34 offisiere en 109 instrukteurs gemaak. Op daardie tydstip was al die offisiere reeds opgelei, terwyl 'n totaal van 65 onderoffisiere reeds gekwalifiseer en in die verskeie kampe, gebiede en eenhede diens gedoen het. Die meeste van hierdie liggaamlike opleidingspersoneel was onder die ouderdom van 35 jaar en het tot die A.1.mediese kategorie behoort. In die lig van die destydse Eerste Minister se beroep dat jonger manne vrygestel moet word vir die voorsetting van die oorlog het die Direkteur van Militêre Opleiding voorgestel dat liggaamlike opleidingspersoneel onder die ouderdom van 35 jaar en tot die A.1.-mediese kategorie behoort deur militêre persone bo die ouderdom van 35 jaar en van 'n laer mediese kategorie vervang moet word.

Om te verseker dat liggaamlike en rekreatiewe opleiding dwarsdeur die Unie-Verdedigingsmag op ' $n$ eenvormige en behoorlike grondslag uitgevoer word, wat dit nodig dat kandidate van laasgenoemde ouderdomsgroepe kursusse wat tydperke van verskillende tydsduur sou duur aan die Tak Liggaamlike Opleiding van die S.A. Militêre Kollege volg.

Die Direkteur van Militêre Opleiding vermeld voorts in sy voorstelle dat die deelname van die ouer liggaamlike opleidingspersoneel in oefening en spele van hul mediese kategorie sal afhang. Om hulle in staat te stel om hul kennis aan 'n klas oor te dra, sal die onderskeie spele en oefeninge deur die opgeleide instrukteurs van die Tak Liggaamlike Opleiding gedurende kursusse aan hulle gedemonstreer word. Om in hierdie doel te slaag, was dit noodsaaklik dat die stelsel van opleiding aan die Tak Liggaamlike Opleiding gewysig word en om alle onderrig m.b.t. gimnastiekapparaat vir die duur van die oorlog uit te skakel.

Hierdie voorstelle het tot gevolg gehad dat die leerplanne vir liggaamlike opleidingskursusse in die Unie-Verdedigingsmag gewysig is.

Vanaf November 1942 het offisiere 'n kursus gevolg wat 8 weke geduur het, terwyl die instrukteurskursus s'n oor 6 weke gestrek het. Kursusse vir die opleiding van remediële instrukteurs sou voortaan 8 weke duur, terwyl die kursus vir boksbeoordelaars en skeidsregters oor 10 dae gestrek het.

Ten einde eenheidsbevelvoerders in die geleentheid te stel om die Tak Liggaamlike Opleiding van die S.A. Militêre Kollege te besoek, is 'n vyfdaagse kursus vir hulle gereël. Genoemde bevelvoerders is hierdeur die geleentheid gegun of self te sien watter werk op die gebied van liggaamlike opleiding aan die Tak Liggaamlike Opleiding verrig word. Verder sou dit meer belangstelling t.o.v. dié vak by die bevelvoerders aanwakker en hulle in staat stel om beter toesig oor die uitvoering van dié vak in hul eenhede uit te oefen.

\subsection{Liggaamlike Opleidingskursusse 1943}

In 1943 het die instrukteurs van die Tak Liggaamlike Opleiding van die S.A. Militêre Kollege met die aanbieding van die volgende kursusse weereens 'n bedrywige opleidingsiaar beleef:

Vier kursusse in Ongewapende Gevegte,

vyf kursusse in Liggaamlike- en Rekreatiewe Opleiding vir onderoffisiere, twee kursusse vir assistent-instruktrises in Liggaam Opleiding vir lede van die Vroue-Hulpdienste,

een kursus in Liggaamlike en Rekreatiewe Opleiding vir kadetoffisiere, 
vyf kursusse vir die opleiding van beoordelaars en skeidsregters in boksgevegte,

twee kursusse in Liggaamlike Opleiding vir senior-offisiere,

twee kursusse vir leidsters in Liggaamlike Opleiding vir lede van die Vroue-hulpdienste,

twee kursusse in Remediële Liggaamlike Opleiding,

een kursus in Liggaamlike en Rekreatiewe Opleiding vir offisiere,

een herhalingskursus in Liggaamlike Opleiding vir lede van die Vrouehulpdienste,

twee kursusse in Liggaamlike Opleiding vir offisiere en onderoffisiere,

een spesiale kursus vir skeidsregters van winterspele vir lede van die Vroue-hulpdienste,

een spesiale kursus vir skeidsregters in somerspele vir lede van die Vrouehulpdienste,

een gevorderde instruktrise-kursus in Liggaamlike Opleiding vir lede van die Vroue-hulpdienste,

een herhalingskursus vir onderoffisiere wat reeds in Liggaamlike en Rekreatiewe Opleiding gekwalifiseer is en een spesiale kursus in Liggaamlike Opleiding vir die remediële behandeling van die Unie-Verdedigingsmag.

\subsection{Inskakeling van Massa-sport in die Militêre Opleidingsprogramme}

Terwyl die opleiding van instrukteurs in liggaamlike opleiding in 1943 volgens die nuwe stelsel onverpoosd aan die Tak Liggaamlike Opleiding van die S.A. Militêre Kollege voortgeduur het, het die militêre outoriteite in dieselfde jaar verklaar dat een van die grootste probleme wat hulle moet oorbrug voordat 'n soldaat na die gevegsfront gestuur kan word, is om hom fiks vir die gevegsomstandighede te kry.

Om die soldaat fiks te kry en terselfdertyd sorg te dra dat sy vryetyd doeltreffend bestee word, het die militêre owerhede in Suid-Afrika besluit dat massa-deelname aan sport en rekreatiewe opleiding in die normale opleidingsprogramme van alle eenhede ingesluit moet word.

Die doel waarna hier gestreef is, was om spesialisasie deur sekere spesifiek opgeleide of natuurlik begaafde sportmanne te voorkom en om te verseker dat alle liggaamlike geskikte soldate aan sport en spele sal deelneem.

Om hierdie skema dwarsdeur die Unie-Verdedigingsmag te laat posvat, is die eerste demonstrasie op 3 Februarie 1943 op die terrein van die Garnisoenontspanningsklub op Voortrekkerhoogte gereël. Dié demonstrasie het daarin bestaan dat verskeie spele en sportnommers gelyktydig op dieselfde terrein plaasvind.

Die volgende spele en sportnommers is in genoemde demonstrasie ingesluit: Spanatletiekbyeenkoms, landloop, swem, tennis, boks, stoei, joe-jitsoe, krieket, netoefeninge, grotere en kleinere spele en hindernisbaanopleiding.

Verskeie offisiere en onderoffisiere, soos lt.-kol. D. H. Craven, van die Liggaamlike Opleidingsbataljon, en maj. D. S. Pretorius, bevelvoerder van die Tak Liggaamlike Opleiding, het 'n leidende aandeel in die organisasie van hierdie demonstrasie gehad.

Ook die lede van die Vroue-hulpdienste het tydens hierdie demonstrasie opgetree. Onder leiding van lt. (mej.) M. A. Barrett het hulle aan krieket, ringtennis, netoefeninge, tennis, sagtebal, netbal, kleiner spele, spanatletiek-byeenkoms en swem deelgeneem. 
Die welslae wat met hierdie eerste grootskaalse demonstrasie van massadeelname aan sport behaal is, het bewys dat dit moontlik was om groot aantal deelnemers gelyktydig aan sport te laat deelneem. Die gevolg was dat alle SuidAfrikaanse militêre sentra en eenhede onmiddellik stappe moes doen om rekreatiewe opleiding as deel van die normale militêre opleidingsprogram in te voer.

\subsection{Verandering in die Duur van Kursusse}

Soos reeds vermeld, is die duur van liggaamlike en rekreatiewe opleidingskursusse vir lede van die Unie-Verdedigingsmag in 1942 na 8 weke verleng. Op 21 Mei 1943 het die destydse bevelvoerder van Binnelandse Gebiede egter te kenne gegee dat hy nie die militêre personeel onder sy bevel beskikbaar kan stel om kursusse van 8 weke by die Tak Liggaamlike Opleiding by te woon nie. Gevolglik het die kommandant van die S.A. Militêre Kollege voorgestel dat beide, die offisiers- en onderoffisierskursusse vir die opleiding van instrukteurs in liggaamlike opleiding wat op daardie tydstip 8 weke geduur het, in twee dele verdeel moet word. Die eerste deel, van 4 weke, moet aan rekreatiewe opleiding en spele gewy word, terwyl die tweede deel slegs liggaamlike opleiding moet insluit. Beide dele moet elkeen vier weke duur en militêre kursusgangers moet een of albei dele kan volg.

Hierdie voorstelle is op 21 Mei 1943 deur die direkteur van Militêre Opleiding aanvaar en die eerste van hierdie kursusse het op 20 Julie 1943 by die Tak Liggaamlike Opleiding 'n aanvang geneem.

\subsection{Die Instelling van 'n Spesiale Kursus vir die Liggaamlike Rehabilitasie vir Lede van die Unie-Verdedigingsmag}

Die Unie-Verdedigingsmag het na die stigting van die Spesiale Diensbataljon in 1933 militêre baanbrekerswerk op die gebied van liggaamlike rehabilitasie gedoen met die instelling van die Liggaamlike Opleidingsbataljon in 1940. Seuns en jong manne wat aan herstelbare liggaamlike gebreke gely het, het deur middel van remediële oefeninge en algemene liggaamlike opleiding sodanig herstel dat hulle as volwaardige landsburgers in een of ander militêre of siviele beroep geplaas kon word.

Kort voor die einde van Junie of die begin van Julie 1943 is 'n konferensie by die S.A. Militêre Kollege belê waarop voorgestel is dat 'n spesiale liggaamlike opleidingskursus by die Tak Liggaamlike Opleiding van die S.A. Militêre Kollege gereël moet word vir sekere langtermyn-pasiënte wat 'n groot aantal beddens in S.A. Militêre Hospitale in beslag neem.

Die konferensie het uit die kommandant van die S.A. Militêre Kollege, 'n verteenwoordiger van die Hoof van die Generale Staf, die mediese konsultant van die direkteur-generaal Mediese Dienste, die geneesheer-generaal van die Unie-Verdedigingsmag, die bevelvoerder van die Liggaamlike Opleidingsbataljon, die bevelvoerder van die Tak Liggaamlike Opleiding, die adviseur van fisieke medisyne van die Unie-Verdedigingsmag en die mediese offisier van die Liggaamlike Opleidingsbataljon bestaan. Genoemde lede van die konferensie het verder aanbeveel dat 'n aanvanklike aantal van 50 pasiënte deur 'n keurraad gekies word en op die eksperimentele kursus na die Tak Liggaamlike Opleiding van die S.A. Militêre Kollege oorgeplaas word.

Daar is in die vooruitsig gestel dat pasiënte wat aan die volgende gebreke en ongesteldhede gely het d.m.v. hierdie kursus baat sou vind:

1. Geringe senuweebeserings. 
2. Gebreke in sekere liggaamsdele soos frakture wat 'n verswakking van die betrokke leciemaat tot gevolg het, atrofeerde dyspiergevalle e.d.m.

3. Gevalle waar spiertonus verswak het as gevolg van lang verblyf in hospitale.

4. Sekere ingewandsgevalle.

5. Kroniese rugpyn, e.d.m.

Die verteenwoordigers op bogenoemde konferensie was ook van oordeel dat pasiënte wat geringe verband-behandeling ontvang het ook op die eksper1mentele kursus geplaas kon word. Die mediese offisiere van die Liggaamlike Opleidingsbataljon en die Tak Liggaamlike Opleiding kon hulle verder behandel.

Gevalle wat individuele oefening nodig het, sou individuele aandag ontvang en slegs gevalle wat geskik is om massa-oefeninge te ondergaan sou as sodanig behandel word.

Gekeurde pasiënte sou uit die hospitaal-atmosfeer verwyder word en nie langer as hospitaalpasiënte beskou word nie.

Dic deelnemers aan die konferensie het voorgestel dat 'n keurraad, bestaande uit die volgende saamgestel moet word om dadelik met die keuring van pasiënte voort te gaan:

Voorsitter:

Die kommandant van die S.A. Militêre Kollege.

Lede:

Die bevelvoerder van die Liggaamlike Opleidingsbataljon,

die mediese offisier van dis chirurgiese afdeling van die Militêre Hospitaal, Voortrekkerhoogte,

die mediese offisier van die mediese afdeling van dieselfde Militêre Hospitaal.

Die keurraad moes die eerste groep pasiënte uit gevalle in die S.A. Militêre Hospitaal op Voortrekkerhoogte kies en indien nodig na die Militêre Hospitaal op Sonderwater en in Johannesburê uitgebrei word.

Opleidingsprogramme vir die verskillende kategorieë waarin die pasiënte verdeel word, moes weekliks in samewerking met mediese offisiere saamgestel word. Dic nasiënte se verblyf aan die S.A. Militêre Kollege sou van hul fisieke toestand cn die vordering wat hulle na aanleiding van die behandeling maak, afhang.

Hierdie voorstelle is op 5 Augustus 1943 deur die Hoof van die Generale Staf goedgekeur en kursus 1415P het op 20 Augustus 1943 'n aanvang by die Tak Liggaamlike Opleiding van die S.A. Militêre Kollege geneem.

\subsubsection{Uitbreiding van Kursus 1415P}

Namate die behandeling deur middel van oefening suksesvol geblyk het, het die militêre outoriteite besluit dat hierdie skema na teruggekeerde Suid-Afrikaanse oud-krygsgevangenes uitgebrei moet word. Die gedagte was om hierdie voormalige krygsgevangenes, afkomstig van Italië en Duitsland en geïnterneerdes van Switserland, na die S.A. Militêre Kollege te stuur waar hulle ondersoek sou word om te bepaal of hulle enige remediële behandeling nodig het. Nadat daar met 'n klein aantal begin is, het dit vinnig toegeneem en in Februarie 1945 was daar ongeveer 1000 name op die kursuslys. 


\subsubsection{Organisasie en Werksaamhede}

Die terugkerende voormalige krygsgevangenes van die verskillende gevegsfronte is by hul aankoms in die Unie van Suid-Afrika op verskeie maniere behandel. Een daarvan was dat so 'n teruggekeerde 90 dae verlof toegestaan is waarna hy by die Tak Liggaamlike Opleiding moet aanmeld. Hier is hy in 'n ontvangsdepot opgeneem waar hy onmiddellik deur mediese offisiere ondersoek is. Nadat die ondersoek afgehandel was, is sommige gevalle vir verdere ondersoek en indien nodig vir opname na die Militêre Hospitaal op Voortrekkerhoogte gestuur.

By genoemde hospitaal het fasiliteite vir konsultasies met chirurge, geneeshere en spesialiste asook geriewe vir volledige X-straal ondersoek bestaan. Op hierdie wyse is alle organiese siektes gediagnoseer en behandel. Nadat die behandeling van siektes voltooi was, het die fisieke behandeling by die Tak Liggaamlike Opleiding van die S.A. Militêre Kollege begin.

In die kamp, waarin die pasiënte gehuisves is, was 'n ontvangsdepot of -afdeling met 'n offisier in bevel. Bykomend tot sy pligte as ontvangsoffisier het hy ook aandag aan navrae oor betaling, uitrusting, e.d.m. geskenk. Twee mediese offisiere, van wie een met kennis van fisiese medisyne, het hulle ook in die kamp bevind waar hulle alle gevalle by hul aankoms ondersoek en die pasiënte se liggaamlike en geestelike gebreke probeer bepaal het. Behandeling is dan volgens behoeftes voorgeskryf. In die kamp is mediese ondersoekkamers en 'n volledig toegeruste apteek en verbandkamer ingerig waar die siekes behandel kon word.

Een van die grootste probleme wat as gevolg van die toenemende aantal pasiënte ontstaan het, was die vraag na personeel wat administratiewe en ander take kon verrig. Daar het geen neergelegde struktuur vir hierdie kamp bestaan nie en dit was bykans onmoontlik om die dienste van opgeleide personeel te verkry. Die gevolg hiervan was dat die militêre owerhede verplig was om die nodige personeel uit die geledere van die pasiënte te bekom. Hierdie reëling het meegebring dat die gekose personeel eers opgelei moes word. Sommige van hulle is na voltooiing van hul opleiding ontslaan. Dan moes ander weer opgelei word om hul plekke te vul. Hierdie personeel het as klerke in die verskeie afdelings van die gimnasium, die mediese ondersoekkamers en die ontvangs.lepot diens gedoen. Ander het tikwerk behartig. Die sers.-maj. van die kamp en sy hele personeel was afkomstig uit die geledere van die pasiënte, terwyl die sekretaris van die menasie en sy spyseniers almal pasiënte op kursus was.

Welsynwerk het in so 'n mate toegeneem dat 'n spesiale welsynkantoor opgerig is wat i.v.m. welsynaangeleenthede met die verskillende afdelings van die leër geskakel het. Die personeel wat in die welsynkantoor werksaam was, was dus in 'n posisie om die militêre owerhede met raad te bedien betreffende die plasing van pasiënte wat ontslaan staan te word. Hierdie plasing van pasiënte het nie net in militêre verband gestaan nie, maar is na verskeie dele van die Unie uitgebrei om sodoende baie mense die geleentheid te gee om diens in hul tuisdorpe te verrig. Die militêre medici en psigiaters het hierdie reëling as noodsaaklik vir die spoedige herstel van pasiënte beskou.

Voorsiening is ook in die kamp vir 'n arbeidsterapie-afdeling gemaak. Die mediese offisiere het arbeidsterapie as 'n noodsaaklike hulpmiddel vir die behoud van 'n goeie gesondheid beskou. Om die probleem van ledigheid in die kamplewe van die pasiënt uit te skakel, is pogings aangewend om sy hele dag d.m.v. óf liggaamlike opleiding en arbeidsterapie te vul. Die arbeidsterapie-afdeling was egter nie ten volle toegerus om alle pasiënte te hanteer nie. Dit het veral vir diegene gegeld wat remediële opleiding nodig gehad het. As gevolg hiervan is pasiënte na die S.A. Militêre Hospitaal op Voortrekkerhoogte gestuur of is 
GARRISON SOCCER CLUB.

RUNNERS-UP, TRANSVAAL WAR LEAGUE, 1945.

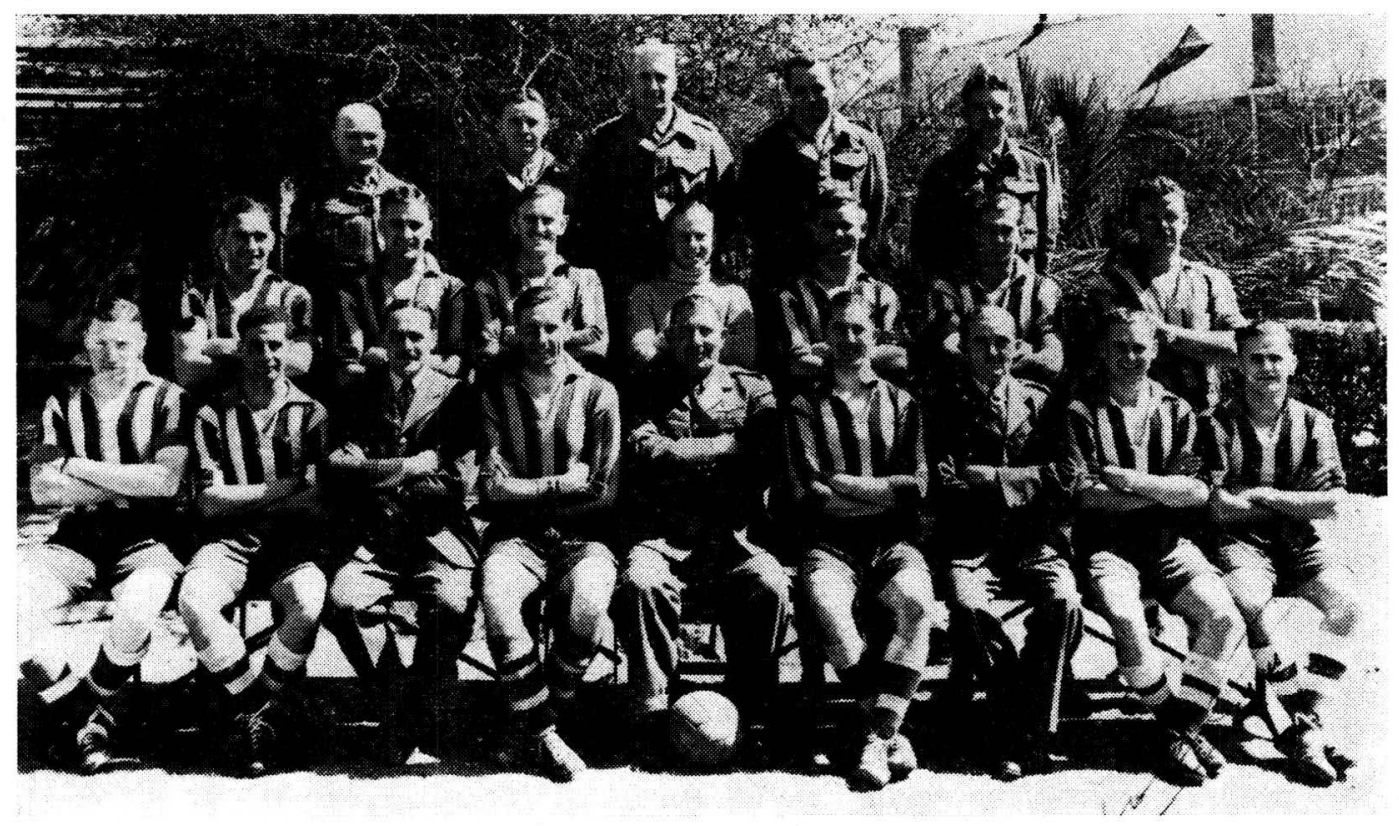

Front Row (sitting l to $r$ ):

Second Row (l to $r$ ):

Back Row: (l to $r$ ):
Lt. S. G. Reece, Cpl. P. D. Jaffer, F.Lt. S. A. Tomlin (Team Manager), F.O. J. McN. C. Clark (Captain), Brig. H. B. Klopper, D.C.O. (Northern Command), S/M. G. Robertson (Vice-Captain), Maj E. W. V. Ryan (Chairman), Sgt. G. P. Watson, S.Sgt. F. Sydow.

Cpl. A. G. Bunce, Sgt. S. Fourie, Sgt. D. A. Bydawell, Lt. C. F. Prior, Cpl. A. H. Butler, Cpl. R. G. Hampton, Lt. E. G. Dowell.

Sgt. W. L. Churchman (Trainer), S.Sgt. D. D. E. Powell (Sec.), Lt. J. O. Hoatson (Committee Member), Sgt. D. M. Parker (A. Trainer), S.Sgt. J. Ramsay (Committee Member).

Photograph and Caption: Martin Gibbs/S.A.A.F 
die personeel van die Tak Liggaamlike Opleiding opgedra om op bovermelde wyse te werk. Die mediese offisiere was egter van oordeel dat pasiënte sover moontlik van die hospitaalatmosfeer weggehou moet word aangesien hulle hulself nie as siek pasiënte wat hospitaalbehandeling nodig het, moet beskou nie. Dit sou hulle herstel bespoedig.

\subsubsection{Liggaamlike en Remediële Opleiding}

Die Tak Liggaamlike Opleiding van die S.A. Militêre Kollege, waar die eksperimentele kursus in liggaamlike rehabilitasie aangepak is, het in 1943 oor die volgende noodsaaklike fasiliteite beskik: Twee groot gimnasiums, groot speelvelde, 'n swembad, tennisbane, 'n gholfbaan, rolbalbane, rugby-, krieket-, en hokkievelde, 'n dans- en bioskoopsaal.

Die personeel het o.m. uit administratiewe staf, opgeleide instrukteurs in algemene liggaamlike opleiding, remediële opleiding sowel as mediese personeel, insluitende 'n psigiater en 'n kliniese sielkundige, bestaan. Hierbenewens kon pasiënte ook van die dienste van konsultante by die Militêre Hospitaal op Voortrekkerhoogte gebruik maak.

Bo en behalwe die ontvangsdepot is die Tak Liggaamlike Opleiding in 'n kompanie vir diegene wat algemene liggaamlike opleiding moes ontvang en 'n kompanie vir remediële oefeninge verdeel.

Liggaamlike opleidingsprogramme is deur die mediese offisiere van bogenoemde inrigting voorgeskryf en onder hul toesig uitgevoer. Dié programme, tesame met die remediële oefeninge, is saamgestel, gegradeer en voorgeskryf volgens die behoeftes van elke pasiënt. Aanvullend tot hierdie oefenprogramme is verskeie spele soos swem, rolbal, tennis, fietsry, en perdry beoefen.

In gevalle waar geen beskadiging of gebreke by pasiënte voorgekom het nie, het hulle algemene liggaamlike opleiding ontvang. Hierdie opleidingsprogramme het 'n reeks van 5 lesprogramme behels wat progressief verswaar is. Pasiënte moes een week aan elke lesprogram bestee. Dit het beteken dat die kursus 5 weke geduur het. Gedurende hierdie tydperk is liggaamlike opleidingstoetse afgeneem wat met die pasiënt se vordering vergelyk is. In sommige gevalle was individue slegs in staat om makliker oefeningprogramme te volg en moes die tempo as gevolg van beserings of siekte gedurende die behandelingstydperk vertraag word.

Vir individue wat aan gebreke van die bewegingssisteem soos swakheid, pyn, beperking of verlies van beweging in gewrigte gely het, is remediële oefeninge voorgeskryf.

Die verskillende klasse is na die liggaamdeel waar die gebrek voorgekom het bv. voet-, knie-, heup-, rug-, skouer-, elmboog-, gewrig- en hand-, respiratoriese- en abdominale klasse vernoem.

In Januarie 1945 het die rehabilitasieskema vir die volgende behandelinge voorsiening gemaak:

1. Arbeidsterapie.

2. Ontspanningsaktiwiteite vir remediële gevalle.

3. Anterior abdominale muurbehandeling.

4. Postuuroefeninge.

5. Vingers en duime.

6. Gewrigte.

7. Elmboë.

8. Styfheid van die skouer. 
9. Herstel van voetbeserings.

10. Funksionele gebreke van die voet.

11. Spele vir lede met voetbeserings.

12. Beserings van die been en enkel.

13. Kniebeserings.

14. Dybeenbeserings.

15. Heupbeserings.

16. Asemhalingoefeninge.

17. Rollier se bestralingsmetode (sonbrand).

18. Burger se oefeninge en passiewe vaskulêre oefeninge.

19. Gebreke van die ruggraat.

Die werksaamhede t.o.v. hierdie skema het tot na die Tweede Wêreldoorlog voortgeduur tot tyd en wyl die militêre owerhede besluit het dat daar geen behoefte meer aan so 'n skema bestaan nie. Kursus 1415P, wat as 'n eksperimentele kursus in 1943 begin het, is tot 'n omvangryke liggaamlike rehabilitasieskema uitgebou en het op 18 Januarie 1947 ten einde geloop.

\subsection{Liggaamlike Opleidingskursusse 1944}

Terwyl die rehabilitasieskema in volle swang was, is die volgende reeks kursusse vir 1944 aan die Tak Liggaamlike Opleiding van die S.A. Militêre Kollege beplan:

Vier kursusse vir assistent-instrukteurs in Remediële Liggaamlike Opleiding,

een kursus vir die opleiding van boksskeidsregters,

een kursus in ongewapende gevegte,

twee kursusse vir die opleiding van assistent-instrukteurs in Liggaamlike Opleiding.

Dit is duidelik dat die klem in 1944 op die opleiding van instrukteurs in remediële opleiding geval het. Hierdie instrukteurs was nodig om remediële oefening aan die pasiënte te gee wat tot kursus $1415 \mathrm{P}$ toegelaat is.

Terwyl die aktiwiteite op die gebied van liggaamlike opleiding in die Unie-Verdedigingsmag voortgesit is, het die Publisiteitskomitee vir Maatskaplike Staatsdienste op 20 September 1944 bekend gemaak dat 'n studentespan, bestaande uit mans en dames van die Universiteit van Stellenbosch se afdeling vir Liggaamlike Opvoeding 'n gimnastiekvertoning in Pretoria sal aanbied. Die studentespan het op 26 September 1944 in samewerking met plaaslike liggame soos die Liggaamlike Opleidingsbataljon, die Pretoriase Atletiekklub en die Universiteit van Pretoria die gimnastiek- en atletiekvertoning op die Caledoniese terrein in Pretoria aangebied.

Die program het o.m. die volgende items ingesluit: Gimnastiek, insluitende apparaatwerk, atletiek, stoei en gewigoptel.

\subsection{Die Eerste S.A. Kongres vir Liggaamlike Opvoeding}

Die Unie-Verdedigingsmag het in Desember 1944 'n uitnodiging om verteenwoordigers na die Eerste S.A. Kongres vir Liggaamlike Opvoeding te stuur wat vanaf 9 tot 12 Januarie 1945 te Stellenbosch gehou is, aanvaar. Aanvanklik sou brig. H. B. Klopper, D.S.O., die Departement van Verdediging op hierdie kongres verteenwoordig, maar maj. Van den Heever en kapt. E. T. T. Thacker, van die Tak Liggaamlike Opleiding, S.A. Militêre Kolloge, is ook toegelaat om genoemde kongres by te woon. Op 4 Januarie 1945 is die afvaardiging deur die toevoeging van lt.-kol. D. H. Craven, lt. A. P. Rutgers en It. (mev.) V. Lounsburry vergroot. 
Tydens hierdie kongres het 1t. (mej.) M. A. Barrett 'n referaat oor die werksaamhede van die Vroue-hulpdienste van die Unie-Verdedigingsmag met spesiale verwysing na die liggaamlike opleidingsaspek gelewer $(80: 93)$.

\subsection{Liggaamlike Opleidingskursusse 1945}

Daar is reeds daarop gewys dat die klem in 1944 meer op die opleiding van remediële instrukteurs as op die algemene liggaamlike opleidingsinstrukteurs geval het. In 1945 is slegs een sodanige kursus aangebied, terwyl daar drie kursusse vir die opleiding van assistent-instrukteurs in Liggaamlike Opleiding aan die Tak Liggaamlike Opleiding gereël is. Vermoedelik het die Unie-Verdedigingsmag nou 'n versadigingspunt m.b.t. die opleiding van remediële instrukteurs bereik. Hierbenewens kon militêre studente ook 'n Gevorderde kursus in Liggaamlike Opleiding asook 'n boksskeidsregterskursus volg.

Dit is opmerklik dat daar gedurende 1944 en 1945 geen kursusse in liggaamlike opleiding en spele aangebied is nie. Dit moet o.i. toegeskryf word dat die oorlog ten einde geloop het en daar gevolglik nie so 'n groot aanvraag na opgeleide liggaamlike opleidingsinstrukteurs meer bestaan het nie.

\subsection{Liggaamlike Opleidingskursusse 1946}

In 1945 is die vyandelikhede aan die verskeie gevegsfronte gestaak en was die Unie-Verdedigingsmag hoofsaaklik bedrywig om demobilisasiemaatreëls te tref. Die gevolg was dat toestande geleidelik weer na die vredetydse teruggekeer het.

In die Unie-Verdedigingsmag is daar ewenwel nog steeds aandag aan die liggaamlike rehabilitasie van terugkerende soldate geskenk wat kursus $1415 \mathrm{P}$ bygewoon het.

As gevolg hiervan is daar weereens 'n assistent-instrukteurskursus in Remediële Liggaamlike Opleiding aan die Tak Liggaamlike Opleiding van die S.A. Militêre Kollege gereël. Ander kursusse wat ook in 1946 aan genoemde inrigting aangebied is, was: 'n Atletiekinstrukteurskursus, 'n boksinstrukteurskursus, 'n kursus vir die Liggaamlike Opleiding van skoolkadetoffisiere asook 'n kursus in Liggaamlike Opleiding vir skoolkadette en Normaalkollege-studente. Hierbenewens is daar ook 'n kursus vir offisiere en onderoffisiere van die S.A. Lugmag in Liggaamlike Opleiding aan die Tak Liggaamlike Opleiding aangebied.

\subsection{Die Kursus vir Skoolkadetoffisiere}

Die kadetoffisierskursus in liggaamlike opleiding was die eerste na-oorlogse kursus van hierdie aard wat deur die Unie-Verdedigingsmag aangebied is. Dit het twee weke geduur en vanaf 1 Julie 1946 tot 12 Julie 1946 gestrek.

Die doel hiervan was om aan kadetoffisiere 'n grondige kennis van die beginsels van die teorie en praktyk van liggaamlike opleiding te gee. Dit sou hulle in staat stel om die leiding by die aanbieding van daaglikse lesprogramme in hierdie vak aan hul onderskeie skole en kolleges te neem.

Kapt. H. Schmidt was kursusbevelvoerder en stafsers. W. de Waal het as instrukteur opgetree.

Die leerplan van hierdie kursus het die volgende onderwerpe ingesluit:

1. Praktiese onderwerpe

1. Vryoefeninge.

2. Leierskap in liggaamlike opleiding.

3. Springkas en grondwerk. 
4. Vrywillig.

5. Spanatletiek-byeenkoms.

6. Medisynbal-oefeninge.

7. Stoeikuns.

8. Groter en kleiner spele.

9. Binne- en buitemuurse hindernisbaanopleiding.

10. Bokskuns.

11. Padoefeninge.

2. Lesings

1. Die organisasie van 'n spanatletiek-byeenkoms.

2. Die organisasie van 'n bokstoernooi.

3. Besprekings.

3. Lesing-Demonstrasies

1. Verswaring van behendigheidsoefeninge.

2. Verswaring van gimnastiekoefeninge.

3. Verswaring van lesprogramme vir rekrute.

4. Demonstrasie van boksreëls, handgemeen en skerm.

4. Eksamens en Toetse

1. Leierskap - vryoefeninge.

2. Skriftelike eksamen - bokskuns, spanatletiekbyeenkoms en stoeikuns.

5. Sertifikate

1. Leierskap - prakties 100 punte.

2. Teorie - beoordeel op skriftelike eksamen 100 punte.

Om in die kursus te slaag, moes ' $n$ minimum van $65 \%$ behaal word.

Geen voorsiening is in bogenoemde leerplan vir belangrike onderwerpe, soos anatomie en fisiologie, gemaak nie alhoewel dit slegs 'n leierskursus was.

\subsection{Liggaamlike Opleidingskursusse vir Lede van die S.A. Lugmag}

Sover vasgestel kon word aan die hand van plaaslik beskikbare bronne is instrukteurs in liggaamlike opleiding aan die Tak Liggaamlike Opleiding van die S.A. Militêre Kollege opgelei vir die hele Unie-Verdedigingsmag d.w.s. vir al drie vertakkings van die Unie-Verdedigingsmag.

Vanaf 1 Augustus tot 31 Augustus 1946 is 'n instrukteurskursus in liggaamlike opleiding vir lede van die S.A. Lugmag by die Tak Liggaamlike Opleiding gehou.

Die kursus het een maand geduur en onder leiding van kapt. H. Schmidt, met stafsers. G. Best as instrukteur, gestaan.

Die doel met hierdie kursus was om lede van die S.A. Lugmag in staat te stel om 'n grondige kennis van die elementêre beginsels van die teorie en praktyk van liggaamlike opleiding op te doen. Sodoende sou hulle in staat gestel word om leiding in die daaglikse aanbieding van lesprogramme te neem en om die organisasie en administrasie van rekreatiewe opleiding by hul verskeie lugmagstasies en -formasies waar te neem.

Die leerplan het voorsiening gemaak vir:

\section{Prakties}

1. Lesprogramme vir rekrute.

2. Spelelesprogramme.

3. Lesprogramme in liggaamlike opleiding sonder apparaat. 
4. Lesprogramme met pale.

5. Lesse in bokskuns.

6. Lesse in stoeikuns.

7. Atletiek (baan- en veldnommers).

8. Spanatletiek-byeenkoms.

9. Hindernisbaanopleiding.

10. Padoefeninge.

11. Landloop.

12. Medisynebal-oefeninge.

13. Behendigheidsoefeninge.

14. Klimtou, hys- en maagoefeninge.

15. Grotere en kleiner spele.

2. Teorie

1. Inleidende lesing.

2. Die organisasie van swemgalas, landloop-, spanatletiek-, atletiekbyeenkomste, bokstoernooie deur middel van die Amerikaanseen uitklopmetodes.

3. Die organisasie, administrasie en bestuur van rekreatiewe opleiding.

3. Lesings-Demonstrasies

1. Demonstrasie van boksreëls.

2. Hulpverlening by apparaatgimnastiek.

3. Demonstrasie van skermkuns.

4. Die regte en verkeerde metodes van klasname.

5. Verswaring van behendigheidsoefeninge.

6. Verswaring van gimnastiekoefeninge.

4. Eksamens

1. Praktiese eksamen in leierskap, boks, stoei en organisasie.

2. Skriftelike eksamen in alle vakke afgeneem.

\section{Sertifikate}

1. Leierskap - minimum $65 \%$.

2. Prakties - minimum $65 \%$.

3. Teorie - minimum $65 \%$.

Aan elke suksesvolle kandidaat is 'n bywoningsertifikaat toegeken.

Dit sal opgemerk word dat die klassifikasie van studente in klasse wat voor die Tweede Wêreldoorlog in gebruik was by die toekenning van sertifikate by die na-oorlogse kursusse weggelaat is.

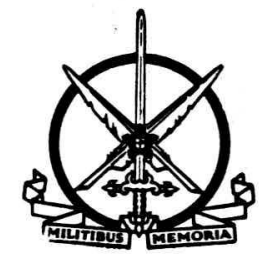




\section{SAMEVATTING}

Die periode 1942 tot 1946 word gekenmerk deur:

1 Die opleiding van instrukteurs in 'n groot verskeidenheid liggaamlike opleidingskursusse.

2. ' $n$ Verandering in die duur van liggaamlike opleidingskursusse vir offisiere en instrukteurs.

3. Die insluiting van massa-sport in die opleidingsprogramme van die Unie-Verdedigingsmag.

4. Die instelling van 'n liggaamlike rehabilitasieskema vir lede van die Unie-Verdedigingsmag.

5. Die terugkeer na vredetydse toestande, insluitende demobilisasiewerksaamhede, in 1946.

Die begrippe liggaamlike opleiding, liggaamlike opvoeding en fisieke fiksheid is in die loop van die voorafgaande omskryf. 'n Poging is ook aangewend om die noodsaaklikheid van fisieke fiksheid vir die individu sowel as vir die militêr te beklemtoon.

Aangesien die Britse invloed ook wortel in die Suid-Afrikaanse militêre geskiedenis geskiet het, is 'n beknopte oorsig oor die verloop van liggaamlike opleiding in die Britse Verdedigingsorganisasie gegee.

Sonder kennis en insig oor die algemene ontwikkelingsgang van die UnieVerdedigingsmag van 1912 tot 1946 is dit onmoontlik om die verloop van liggaamlike opleiding in die Unie-Verdedigingsmag te kan volg.

Die eerste bewys dat liggaamlike opleiding sy plek binne die raamwerk van die toenmalige militêre opleiding ingeneem het, vind ons kort na die totstandkoming van die Unie-Verdedigingsmag in 1912.

Die amptelike regulasies met betrekking tot die Kadetkorps wat in 1913 uitgevaardig is, het ook voorsiening vir liggaamlike opleiding in een of ander vorm gemaak.

Die Britse invloed het, vanaf die ontstaan van die Unie-Verdedigingsmag, op die gebied van liggaamlike opleiding diep wortel geskiet. Dit blyk duidelik uit die handleiding getiteld Manual of Physical Training (Reprint 1914) wat in 1922 deur 1, 2 en 3 Batterye en die Regiment Zuid-Afrikaanse Bereden Schutters gevolg is.

Vanaf 14 September 1922 tot 26 Oktober 1922 is kursus 7G, t.w. 'n kwalifiserende kursus in Liggaamlike en Rekreatiewe Opleiding (S.A. Staande Mag) deur ' $n$ voormalige Britse onderoffisier, sers.-maj. H. Higgenbotham, aan die toenmalige S.A. Militêre Skool aangebied.

Oor die tydperk 1923-24 is twee lang, op Britse lees geskoeide, kursusse vir die opleiding van Suid-Afrikaanse militêre instrukteurs in liggaamlike opleiding deur ' $n$ Britse offisier, maj. T. H.Wand-Tetley, op Robertshoogte, tans Voortrekkerhoogte, gelei.

Sedert die twee lang kursusse wat deur maj. Wand-Tetley in 1923-1924 aan die S.A. Militêre Skool gehou is, is verdere instrukteurskursusse nie meer in die Unie-Verdedigingsmag gehou nie.

Daarna het ' $n$ aantal militêre instrukteurskursusse in liggaamlike opleiding aan die S.A. Polisie Opleidingsdepot gevolg. 
In 1935 is sers. J. A. Wallis na die buiteland gestuur waar hy twee kursusse in hierdie vak aan die Britse opleidingsinrigting te Aldershot, Engeland volg.

Die S.D.B. is tydens die wêreldwye ekonomiese depressie in 1933 gestig. Die grondslag waarop die opleiding in die S.D.B. gerus het, was liggaamlike opleiding en dril met die oog op fisieke en morele ontwikkeling van sy lede. Dié eenheid het daarna gestreef om ' $n$ rekruut in die korts moontlike periode tot so 'n mate te ontwikkel dat hy geskik sou wees om 'n ambag of beroep uit te oefen en om hom fisiek sowel as geestelik gesond te kry.

Die Junior Spesiale Diensbataljon is gestig met die doel om die gaping wat daar tussen skoolverlating en aansluiting by die S.D.B. ontstaan het, te oorbrug.

Liggaamlike opleiding het ook 'n belangrike plek in die opleidingsprogramme van die Junior Spesiale Diensbataljon beklee. Geen voorsiening is egter vir medies ongeskikte seuns gemaak nie.

Die Departement van Volkswelsyn het besef dat die meeste van die medies ongeskikte seuns ' $n$ las van die Staat sou word indien hulle nie vroegtydig behandeling sou ontvang nie.

Nadat proefnemings met die behandeling van hierdie seuns in 1938 by die Junior Spesiale Diensbataljon gedoen is, is so 'n skema in 1940 in die lewe geroep. Die medies ongeskikte seuns is in twee pelotons van 50 lede elk (die K-pelotons) by die Junior Spesiale Diensbataljon op Voortrekkerhoogte gehuisves waar hulle remediële opleiding ontvang het.

In dieselfde jaar is ook besluit om die K-pelotons te vergroot sodat daar in ' $n$ steeds toenemende behoefte vir remediële opleiding van liggaamlik ongeskikte seuns voldoen kon word. Dit het tot gevolg gehad dat die Liggaamlike Opleidingsbataljon (L.O.B.) met ingang van 1 Januarie 1941 gestig is.

Die fisieke fiksheidspeil van die seuns in die L.O.B. is d.m.v. die toepassing van gegradeerde liggaamsoefeninge verhoog, terwyl' $n$ hele aantal liggaamlike gebreke d.m.v. remediële oefeninge herstel is.

skenk.

Benewens verstandelike onderrig is ook aandag aan vakonderrig ge-

In 1937 het lede van die Unie-Verdedigingsmag betekenisvolle bydraes gelewer deur saam met verteenwoordigers van verskeie Staatsdepartemente en ander organisasies behulpsaam te wees met die formulering van' $n$ nasionale skema van liggaamlike opvoeding. Hierdie skema het in 1938 op die stigting van die Nasionale Adviserende Raad vir Liggaamlike Opvoeding uitgeloop.

Die owerhede van die Unie-Verdedigingsmag het in dieselfde tydperk die noodsaaklikheid van ' $n$ behoorlik georganiseerde stelsel van liggaamlike opleiding besef. Die gevolg was dat twee Britse militêre instrukteurs, kapt. F. S. S. Barlow en sers.-maj. G. Barber, in 1938 na die Unie-Verdedigingsmag gesekondeer is om liggaamlike opleidingsinstrukteurs plaaslik op te lei en om 'n skool vir Liggaamlike Opleiding aan die S.A. Militêre Kollege te stig.

Intussen is 2 de lt. D. S. Pretorius na die buiteland gestuur waar hy vanaf 9 November 1937 tot 7 April 1938 'n kursus in liggaamlike opleiding aan die Army School of Physical Training, Aldershot, Engeland, gevolg het. Hy het ook besoeke aan verskeie ander Europese lande gebring. 
Op 1 April 1938 is 'n bekende rugby-Springbok, D. H. Craven, met offisiersrang as Organiseerder van Liggaamlike Opleiding in die Unie-Verdedigingsmag aangestel. Hy het die eerste liggaamlike opleidingskursus wat deur maj. Barlow en sy assistent, sers.-maj. Barber, in Suid-Afrika aangebied is, vanaf 1 Mei 1938 tot 31 Augustus 1938 bygewoon. Op '6 September 1938 het kapt Craven op sy beurt na die buiteland vertrek waar hy o.a. 'n kursus aan die Reichsakademie für Leibesübungen in Duitsland en 'n kursus aan die Army School of Physical Training te Aldershot bygewoon het.

Nadat kapt. Craven nog verskeie ander lande besoek het, het hy op 27 Oktober 1939 weer diens in die Unie-Verdedigingsmag aanvaar waar hy sy nuut verworwe vakkennis en -gedagtes kon toepas.

$\mathrm{Na}$ die uitbreek van die Tweede Wêreldoorlog, in September 1939, het klem op die gebied van liggaamlike opleiding in die Unie van Suid-Afrika op die opleiding van instrukteurs geval. Dit uitbreek van genoemde oorlog het ook daartoe bygedra dat die behoefte aan gekwalifiseerde instrukteurs in die Unie-Verdedigingsmag groter geword het. Om hierdie rede is die dienstermyn van die twee Britse instrukteurs verleng en is vakatures vir instrukteurs in liggaamlike opleiding in dagblaaie geplaas.

Kapt., later maj., Craven is met inging van 11 Junie 1940 na die Tak Liggaamlike Opleiding van die S.A. Militêre Kollege verplaas waar hy op 17 Junie van dieselfde jaar as hoofinstrukteur in liggaamlike opleiding aangestel is. Hy is ook op 8 Julie 1940 as die koördinerende outoriteit van alle liggaamlike en rekreatiewe opleiding in die Voortrekkerhoogte-gebied aangestel. Voorts het hy nog steeds die aanstelling as Stafoffisier Liggaamlike Opleiding op die diensstaat van die Adjunk-Hoof van die Generale Staf by Verdedigingshoofkwartier behou.

Maj. Craven is in 1940 die geleentheid gegee om sy stelsel van spele, waarmee hy die soldate fiks vir oorlogvoering moes maak, in werking te stel.

Die diensstaat van die Tak Liggaamlike Opleiding van die S.A. Militêre Kollege is op 24 Mei 1941 uitgebou om vir meer personeel voorsiening te maak.

Leerplanne vir militêre liggaamlike opleidingskursusse is in Oktober 1941 deur die insluiting van meer lesings oor anatomie en fisiologie asook oor mediese aspekte van liggaamlike opleiding in die leerplanne van instrukteurs uitgebrei. Meer aandag moes ook aan toegepaste anatomie en fisiologie geskenk word, terwyl demonstrasies m.b.t. hierdie vakgebied gereël en rolprente daaroor vertoon word.

In 1940 is die Vroue-hulpdienste as 'n eenheid van die Unie-Verdedigingsmag gestig. Liggaamlike fiksheid het 'n belangrike rol in die opleiding van vroulike lede van die S.A. militêre organisasie gespeel.

Liggaamlike opleiding is in 1941 ook na krysgevangenekampe in SuidAfrika uitgebrei.

Die opleiding van instrukteurs in liggaamlike opleiding het onverpoosd voortgeduur.

As gevolg van de destydse Eerste Minister se beroep dat jonger manne vrygestel moet word vir die voortsetting van die oorlog is besluit dat die liggaamlike opleidingspersoneel onder die ouderdom van 35 jaar, wat tot A.1.-mediese kategorie behoort, deur militêre persone bo die ouderdom van 35 jaar en van 'n laer mediese kategorie, vervang moet word. Hierdie lede het verskeie kursusse met wisselende tydsduur aan die Tak Liggaamlike Opleiding van die S.A. Militêre Kollege gevolg. 
Offisiere het 'n kursus gevolg wat agt weke geduur het, terwyl die instrukteurs s'n oor ses weke gestrek het. Ook is eenheidsbevelvoerders in die geleentheid gestel om d.m.v. 'n kort kursus vertroud te word met die liggaamlike opleiding wat aan die Tak Liggaamlike Opleiding van die S.A. Militêre Kollege gedoseer is. Dit sou hulle in staat stel om beter toesig oor die uitvoering van dié vak in hul onderskeie eenhede uit te oefen.

Die instrukteurs van die Tak Liggaamlike Opleiding het in 1943 ' $n$ bedrywige opleidingsjaar beleef met die aanbieding van 'n reeks liggaamlike opleidingskursusse met wisselende tydsdure.

Fisieke fiksheid vir die vegtende soldaat het nog steeds ' $n$ probleem gebly. Om die soldaat fiks te kry en te hou en terselfdertyd sorg te dra dat sy vryetyd doeltreffend bestee word, het die militêre outoriteite in Suid-Afrika in 1934 besluit dat die deelname aan massa-sport en rekreatiewe opleiding in die normale opleidingsprogramme van alle eenhede ingesluit moet word. Die doel waarna gestreef is, was om spesialiste deur sekere spesifiek opgeleide of natuurlik begaafde sportmanne to voorkom en te verseker dat alle liggaamlik geskikte soldate aan sport en spele deelneem.

' $n$ Verandering is ook in die duur van liggaamlike opleidingskursusse aangebring.

Op 20 Augustus 1943 is 'n liggaamlike rehabilitasieskema vir lede van die Unie-Verdedigingsmag ingestel. Algemene liggaamsoefeninge, kunsvaardighede en remediële oefeninge het meegehelp dat lede wat aan liggaamlike gebreke gely het weer geskik vir die arbeidsmark gemaak is.

In 1944 het die klem op die opleiding van remediële instrukteurs geval.

Die Unie-Verdedigingsmag was in Januarie 1945 deur verskeie offisiere op die eerste S.A. Kongres vir Liggaamlike Opvoeding, wat op Stellenbosch gehou is, verteenwoordig.

In 1945 is die vyandelikhede aan die gevegsfronte gestaak en was die Unie-Verdedigingsmag hoofsaaklik bedrywig om demobilisasiemaatreëls te tref. Die gevolg is dat toestande geleidelik weer na die vredetydse roetine teruggekeer het.
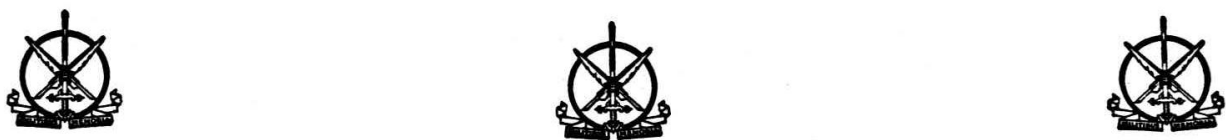


\section{SUMMARY}

Definitions (physical training, physical education, physical fitness) and the necessity for physical fitness for the soldier, together with an exposition on physical training in the then Imperial forces - influences which initially affected the Union Defence Force - constitute the background of this thesis.

Before 1922 not much attention was given to physical training fitness in the Union Defence Force.

In that year a new phase started when the first course in Physical and Recreational Training, based on the British system, was conducted by Sgt. Maj. L. Higgenbotham at the S.A. Military School at Roberts' Heights.

The training courses and programmes of Maj. (later Lt. Col.) T. H. Wand-Tetley, O.B.E., were followed by a period during which the S.A. Police Training Depot provided for the requirements of the Union Defence Force.

Before Sgt. J. A. Wallis attended two training courses in England during 1935, the aims of the Special Service Battalion (1933) and, after 1935, those of the Junior Special Service Battalion (1939), the " $K$ " platoons (1940) and the Physical Training Battalion (1941) created new problems and resulted in the visits of two British military instructors (Maj. S. F. F. Barlow, Sgt. Maj. G. Barber) and, at the same time, in the overseas mission of 2 nd Lt. D. S. Pretorius and Capt. D. H. Craven.

The former was trained in accordance with British principles. After his return and under his guidance the latter initiated a specifically South African approach which initially founded expression in the games system.

The Second World War led not only to a period of hitherto unknown activity, but also to new fields of activity such as physical training for Woman's Auxiliary Services, prisoners of war, training courses for officers and instructors and the introduction of a rehabilitation scheme.

The cessation of hostilities, followed by demobilisation, ended the abovementioned, in various respects, important development phase in the history of physical training in the Union Defence Force.
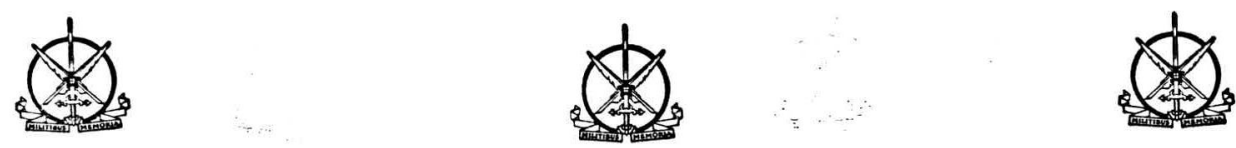


\section{BIBLIOGRAFIE}

\section{A. BOEKE}

1. Bovard, J. F., Cozens, F. W., and Hagman, P. E. Test and Measurements in Physical Education. Philadelphia, W. B. Saunders Co., 1949.

2. Breytenbach, J. H. Die Tweede Wêreldoorlog. Deel I: Voorspel tot die Stryd, Deel II: Ontplooiing van Boere-offensief, Oktober, 1899. Kaapstad, Nasionale Pers Beperk, 1948 en 1949.

3. Bucher, C. A. Foundations of Physical Education. London, Henry Kipton, 2nd ed., 1956.

4. Christensen, L. E., and Trap, P. M. Text-Book of Gymnastics. London, University of London Press, Ltd., 1937.

5. Larson, L. A., and Yocom, R. D. Measurement and Evaluation in Physical, Health and Recreational Education. St. Louis, C. V. Mosby Co., 1951.

6. Maurice, F. History of the War in South Africa. London, Hurst and Blackett Ltd., 1906.

7. McIntosh, P. C. Physical Education in England Since 1800. London, G. Bell and Sons, Ltd., 1952.

8. McPartlin, G. A. Fitness for Sport. London, G. Bell and Sons, Ltd., 1957.

9. Morehouse, L. E., and Miller, A. T. Physiology of Exercise. St. Louis, The C. V. Mosby Co., (3rd ed.) 1959.

10. Muller, C. F. J. Vyfhonderd Jaar Suid-Afrikaanse Geskiedenis. Pretoria en Kaapstad. Academica, 1968.

11. Nash, J. B. Physical Education : Interpretations and Objectives. New York, A. S. Barnes and Co., 1948.

12. Nixon, E. W., and Cozens, F. W. An Introduction to Physical Education. Philadelphia, W. B. Saunders Co., 1943.

13. Rice, E. A., and Hutchinson, J. L. A Brief History of Physical Education. New York, A. S. Barnes and Co., (3rd ed.), 1952.

14. Richtlinien für die Liebeserziehung in Jugendschulen. Weidmannsche Verlagsbuchhandlung, Berlin, 1937.

15. Roux, P. E. Die Verdedigingstelsel van die Kaap onder die Holland-Oos Indiese Kompanjie, 1652-1795. Stellenbosch, 1925.

16. Sharman, J. R. Introduction to Physical Education, New York, A. S. Barnes and Co., 1934.

17. Selye, H. The Stress of Life. London, Longmans, Green and Co., 1957.

18. Spillhaus, M. W. South Africa in the Making 1652-1806. Johannesburg, Juta and Co. Ltd., 1966.

19. Theal, G. M. History of South Africa from 1795-1872. London, George Allen and Unwin, Ltd., Vol. I, 1964.

20. Tylden, G. The Armed Forces of South Africa; with an appendix on Commandos. Johannesburg, Africana Museum, 1954.

21. Van Dalen, D. B., Mitchell, E., and Bennett, B. L. A World History of Physical Education. New York, Prentice Hall, Inc., 1953.

22. Van der Walt, A. J. H., Wiid, J. A. en Geyer, A. L. Geskiedenis van Suid-Afrika. Kaapstad, Nasionale Boekhandel Beperk, Deel I, 1951.

23. Webster, R. W. Philosophy of Physical Education. Iowa, W. M. C. Brown Company Publishers, 1965.

24. Weston, A. The Making of American Physical Education. New York, Appleton-CenturyCrofts, 1952.

25. Williams, J. F. The Principles of Physical Education. Philadelphia, W. B. Saunders Co., 1939. 


\section{B. TYDSKRIFTE EN KOERANTE}

26. American Medical Association and the American Association for Health, Physical Education and Recreation. "Exercise and Fitness," Vigor, 19(2), Maart 1966.

27. "Are we fit enough to fight a War?" The South African Sportsman, September, 1968.

28. Berends, J. J. „Die Eksperiment van Vanves.” Vigor, 10(4), September 1957.

29. Blair-Hook, P. C. C. „Liggaamsoefeninge in die Leër.” Liggaamopvoeding, 1(2), Junie 1939.

30. Botha, J. L. „S.A. onfiksste ter wêreld.” Hoofstad, 25 Julie 1969.

31. Bredin, A. E. C. "The Army Physical Training Corps Centenary : 1860-1960." Journal of the Royal United Service Institution, Vol. 105, 1960.

32. Broeksma, A. H. „Die vorming van burgers en die Departement van Verdediging.” Liggaamsopvoeding, 1(2), Junie 1939.

33. Brouha, L. "The Step Test. A simple method of measuring Physical Fitness for muscular work in young men." Research Quarterly, March, 1934.

34. Burger, A. „Fikswordplan vir S.A. Gevra - Kolonel sê jeug is pap en week.” Die Vaderland, 23 November 1966.

35. Burnett, R. L. Brassey's Naval and Shipping Annual, 1934. London, William Cloves and Sons, Ltd., 1934.

36. "The Citizen Force through the Years." Kommando, 13(6), Junie 1962.

37. Cluver, E. H. and Jokl, E. "A Survey of Physical Efficiency in South Africa," South African Journal of Science, Vol. 38, February, 1941.

38. Coombe, M. H. “Attaining Physical Fitness through Sport." The Star, 24th August, 1940.

39. Craven, D. „Die Liggaamsopleiding-bataljon, Voortrekkerhoogte.” Liggaamsopvoeding. 5(2), Junie 1943.

40. Daily Tribune, Durban, 16.3.1938.

41. Du Toit, S. F. "Exercise as a factor in Coronary Heart Discase." Vigor, 19(4), September 1966.

42. Eisenhardt, I. "Canada's National Fitness Act." Journal of Health, Physical Education and Recreation, 16(4), April 1945.

43. "Fitness First." British Army Annual, No. 1, July, 1954.

44. Forsyth, C. E. "Some things we have learned about Physical Fitness." The Athletic Journal, 25(10), June, 1945.

45. Gillibrand, R. "Physical and Recreational Training in the Royal Navy." Journal of Physical Education, 38(11), 1946.

46. Hein, F. V. and Ryan, A. J. "The Contributions of Physical Activity to Physical Health." Research Quarterly, Vol. 31, Part 2, May, 1960.

47. Jones, H. A. "Report on National Fitness." The Journal of Health and Physical Education, 13(3), March, 1942.

48. Larson, L. A. "Defining Physical Fitness." Education, 13(6), June, 1942.

50. Larson, L. A. "Some findings resulting from the Army Air Forces Physical Training Program." Research Quarterly, 17(2), May, 1946.

51. MacKenzie, A. "Some neglected aspects of Physical Training and Recreation." Physical Education and School Hygiene, 19(88), November, 1937.

52. Meiring, P. „Suid-Afrikaners is nie fiks.” Dagbreek en Sondagnuus, Seksie II, 13 Junie 1965 .

53. The North Lincoln Sphinx, A Regimental Periodical 1860-1862, Pretoria, Die Staatsbiblioteek, 1968.

54. Odendaal, W. A. „Ons word 'n pap volk.” Die Huisgenoot, 23 Augustus 1963. 
55. "Physical Fitness through Fun." Cape Times, 13 November, 1940.

56. Pixley, J. E. and Gubin, E. K. "Physical Training for Army Flyers.' Hygeia, Vol 30, June, 1942.

57. Rowntree, L. G. "Education, Health and Physical Fitness," The Journal of Health and Physical Education, 14(7), September, 1943.

58. „Rus aktief - en word nooit moeg." Hoofstad, 2 Oktober 1968.

59. Rutgers, A. P. „Liggaamsopvoeding as vak vir Stds. VII en VIII aan die Junior Hoërskool van die Liggaamsopvoedingsbataljon." Liggaamsopvoeding, 5(3), September 1943.

60. Schrecker, K. A. „Liggaamlike Opleiding en Verstandelike Werk.” Vigor, 17(4), September 1964.

61. Schrecker, K. A. "Physical Fitness. What it means, what it comprises, and in what relation it stands to other fitness and health." Vigor, 6(4), September, 1953.

62. Schroeder, L. C. "Foundations for Physical Fitness." Journal of Health, Physical Education and Recreation, 16(10), December, 1945.

63. Smit, C. M. „Liggaamlike Fiksheid - 'n Doelstelling van Liggaamlike Opvoeding.” Vigor, 6(1), Desember 1952.

64. Smit, C. „Die ontwikkeling van die term ,Liggaamsopvoeding'," Liggaamsopvoeding, 5(3), September 1943.

65. "Sport in the Army." Cape Argus, 23 November, 1940.

66. Steinhaus, A. H. "Fitness and how we may obtain it." The Journal of Health and Physical Education, 14(8), October, 1943.

67. Van der Merwe, I. R. „Unieke bydraes deur Liggaamlike Opvoeding tot 'n sisteem van Opvoeding." Vigor, 17(4), September 1964.

68. Viljoen, B. G. „Militêre Lugvaart in Suid-Afrika.” Kommando, 7.(8), Augustus 1956.

69. „Die Weermag en die Eerste Wêreldoorlog.” Kommando, 13(6), Junie 1962.

70. Weible, W.L. "Fit to Fight." The Journal of Health and Physical Education, 14(3), March, 1944.

71. Wilson, C. C. "Foundations for Physical Fitness." Health and Physical Education, 13(7), September, 1942.

72. Winterbottom, W. "Physical Training in the Royal Air Force." Journal of Physical Education, Vol. 37, 1945.

\section{INLIGTINGSTUKKE}

73. Buitengewone Staatskoerant van die Unie van Zuid-Afrika, Vol. VI, No. 246, Kaapstad, 14 Junie 1912.

74. Official Year Book of the Union of South Africa and of Basutoland, Bechuanaland Protectorate, and of Swaziland, Pretoria No. 15, 1932-1933.

75. Official Year Book of the Union of South Africa and of Basutoland, Bechuanaland Protectorate, and of Swaziland, Pretoria No. 16, 1933-1934.

76. Ploeger, J. Op Brandwag - Drie Eeue Militêre Geskiedenis van Suid-Afrika. MilitêrHistoriese en Argivale Dienste, Pretoria, April 1968*.

77. Regulasies en Orders en Instruksies voor Kadetkorpsen, Pretoria. The Government Printing and Stationery Office, 1913.

78. Staatskoerant van die Unie van Suid-Afrika, Vol. XIV, No. 422, 14 Oktober, 1913. Goewerments Kennisgewing No. 1570.

79. Die Tweede Wêreldoorlog, Voordruk uit die Offisiële Jaarboek van die Unie van Suid-Afrika. Pretoria. Die Staatsdrukker, Hoofstuk XXIV, No. 23, 1946.

* In 1969 herdruk in Militaria, Tydskrif vir Militêre Geskiedenis/Periodical for Military History, Pretoria, deel 1/4, pp. 1-47. 
D. VERSLAE

80. Barrett, Capt. (Miss). "The Development of Physical Education in the WAAS and WAAF." Verslag van die Eerste S.A. Kongres vir Liggaamlike Opvoeding, 9-12 Januaric 1945, Stellenbosch, Pro-Ecclesia-Drukkery (Edms.) Bpk., 1945.

81. Canadian Sports Advisory Council, British Empire and Commonwealth Games. Physical Efficiency Research Project, Canada, 1958.

82. Pieterse, J. E. (Hoofred.). Verslag van die Jeugondersoek wat deur die Departement Sosiologie van die Universiteit van Pretoria vir die Nasionale Jeugraad onderneem is. Deel III Jeug en Vryetyd, Johannesburg, Voortrekkerpers, 1967.

83. Smit, C. Comparative analysis of results from Kraus-Weber Test of minimum muscular Fitness in South African Children. Universiteit van Pretoria, 1962.

84. Smit, C. ' $n$ Vergelykende studie van die Fisieke Fiksheid van kinders in Suid-Afrika, Brittanje en die V.S.A., gegrond op 'n Suid-Afrikaanse steekproef. Universiteit van Pretoria, Junie 1965.

85. Smit, C. Voorlesings. Departement van Liggaamlike Opvoedkunde, Universiteit van Pretoria.

\section{E. ONGEPUBLISEERDE BRONNE}

86. De Lange, D. P. 'n Ondersoek na die Fisicke Fiksheidsvereistes wat deur die Suid-Afrikaanse Leër gestel word en die mate waarin Transvaalse seuns wat die Middelbare skool verlaat het, hieraan voldoen. Potchefstroom, 1967.

87. Du Toit, S. F. 'n Ondersoek na die Fisieke Geskiktheid van 14 jarige, 15 jarige en 16 jarige Blanke Hoërskoolseuns met betrekking tot Houding, Gesondheid en Liggaamlike Fiksheid. Bloemfontein, 1962.

88. Loubser, T. J. Die plek van Liggaamlike Opvoeding in militêre opleiding in die SuidAfrikaanse Leër, Potchefstroom, 1961.

89. Scholtz, G. J. L. Die fisieke Fiksheid van die Suid-Afrikaanse Weermag, Suid-Afrikaanse Polisie in opleiding en skoliere in Standerd Tien. Potchefstroom, 1968.

F. S.A.W. ARGIEF 